Historic, Archive Document

Do not assume content reflects current scientific knowledge, policies, or practices. 



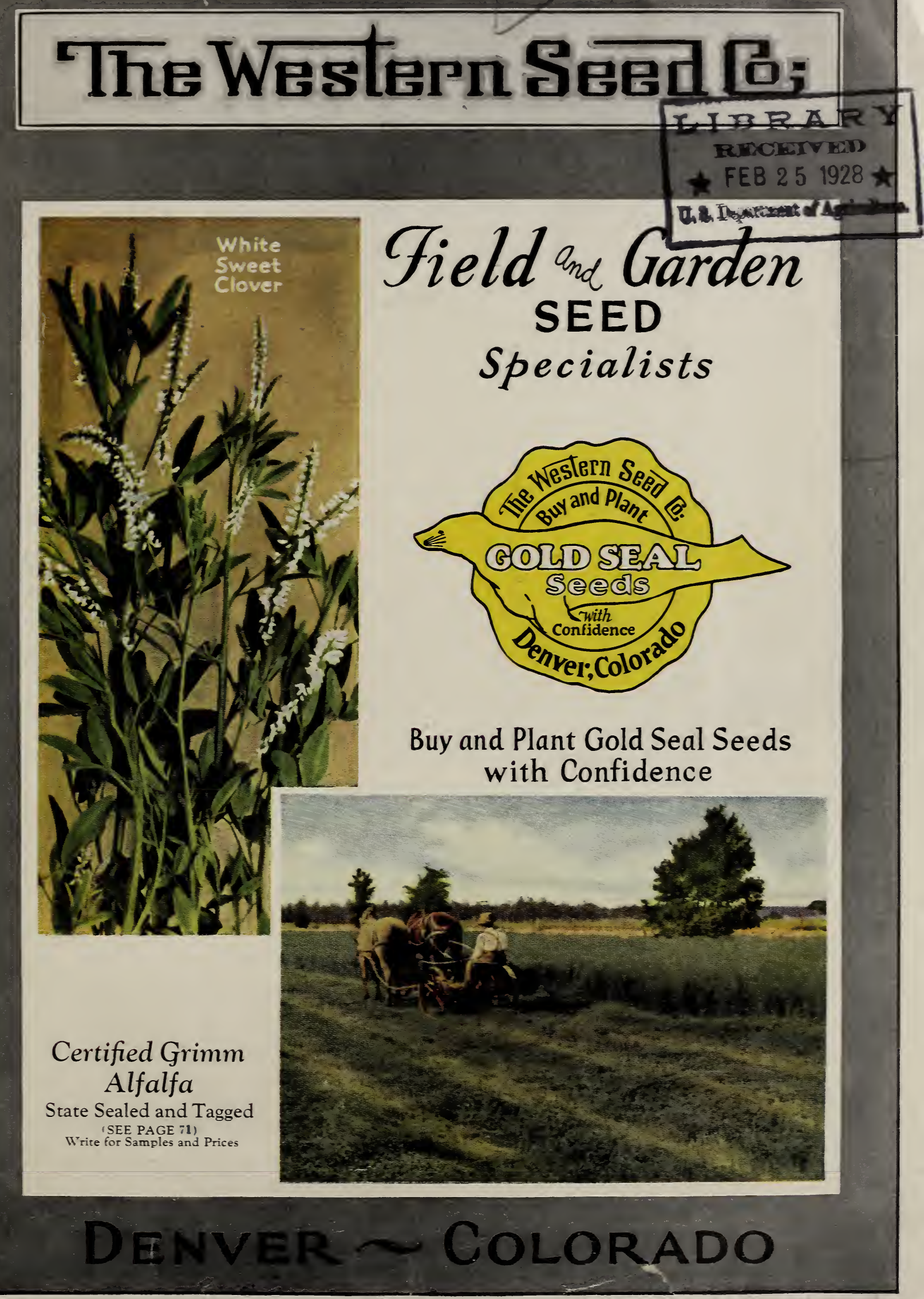




\section{[GREELEY WONDER]}

Especially desiraable for the market gardener and the home garden.

Selected seed, pkt., 10c; oz., $15 \mathrm{c} ; \mathrm{I} / 4 \mathrm{lb}$., $40 \mathrm{c}$; 1 lb., $\$ 1.50$; 5 lbs., $\$ 1.35$ per lb., postpaid. or GOLDEN QUEEN

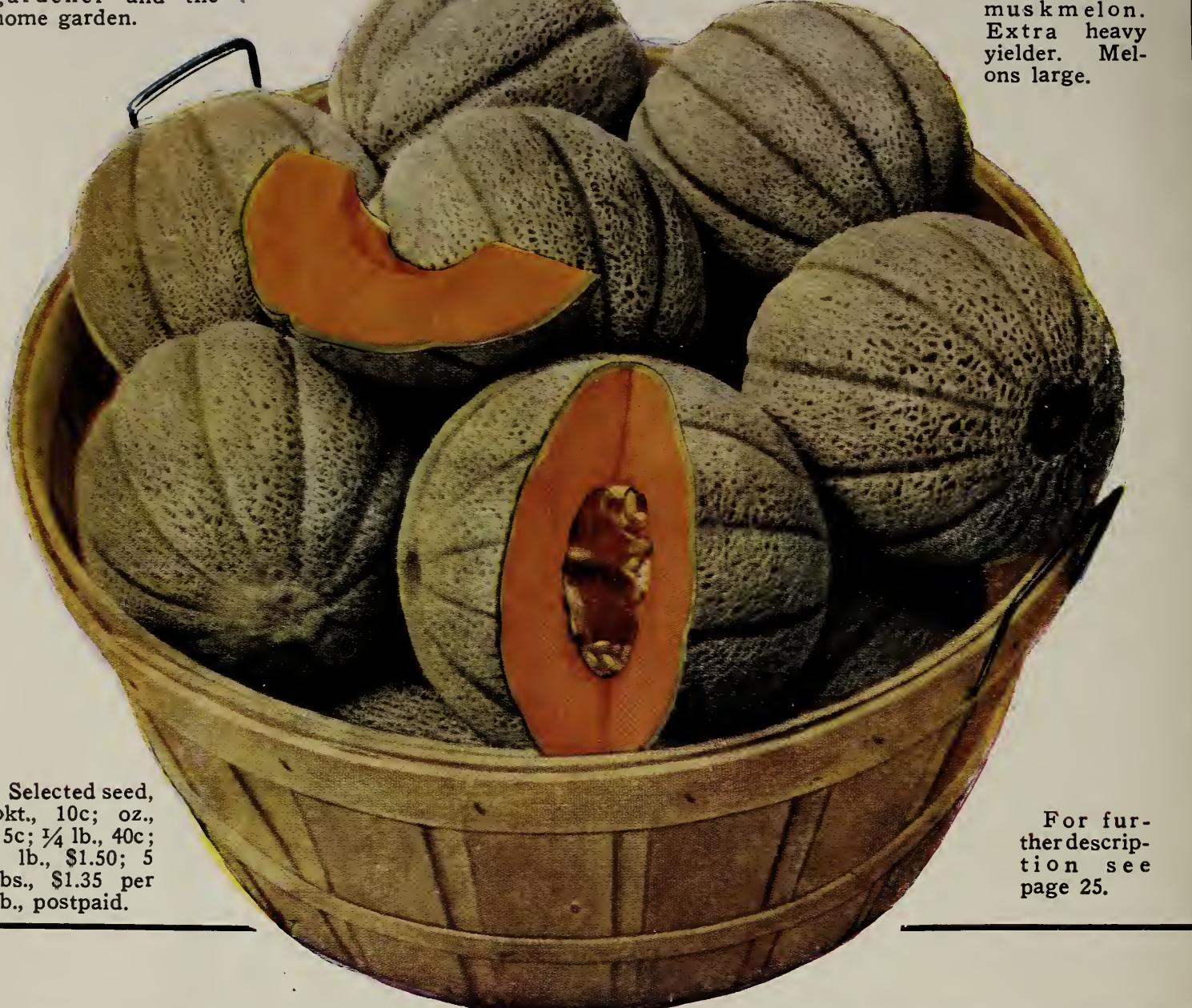

\section{JUMBO SUGAR WATERMELON}

A large, sweet, luscious melon, dark green shell with bright, solid flesh of exceptionally fine texture. Contains one-third more sugar than Tom Watson. Price, packet, 10c; oz., 15c; $1 / 4$ lb., 50c; $1 / 2$ lb., $85 c ; 1$ lb., $\$ 1.65$, postpaid.

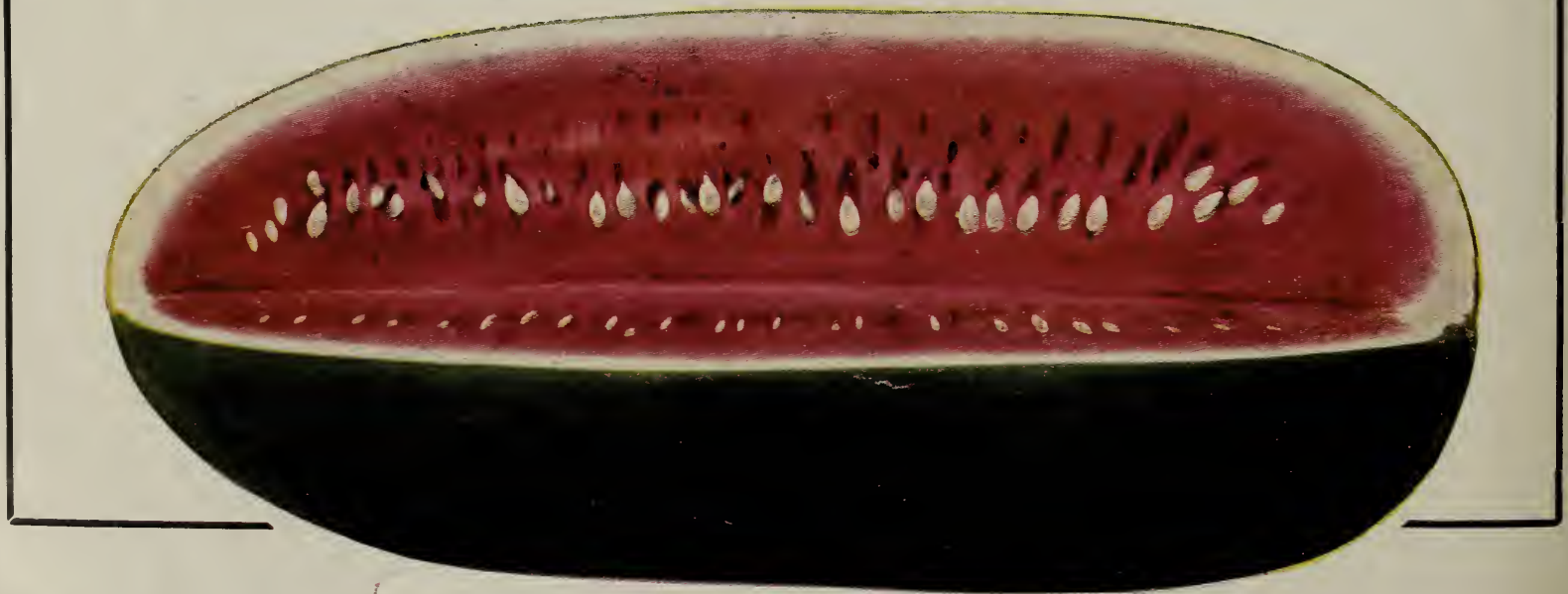




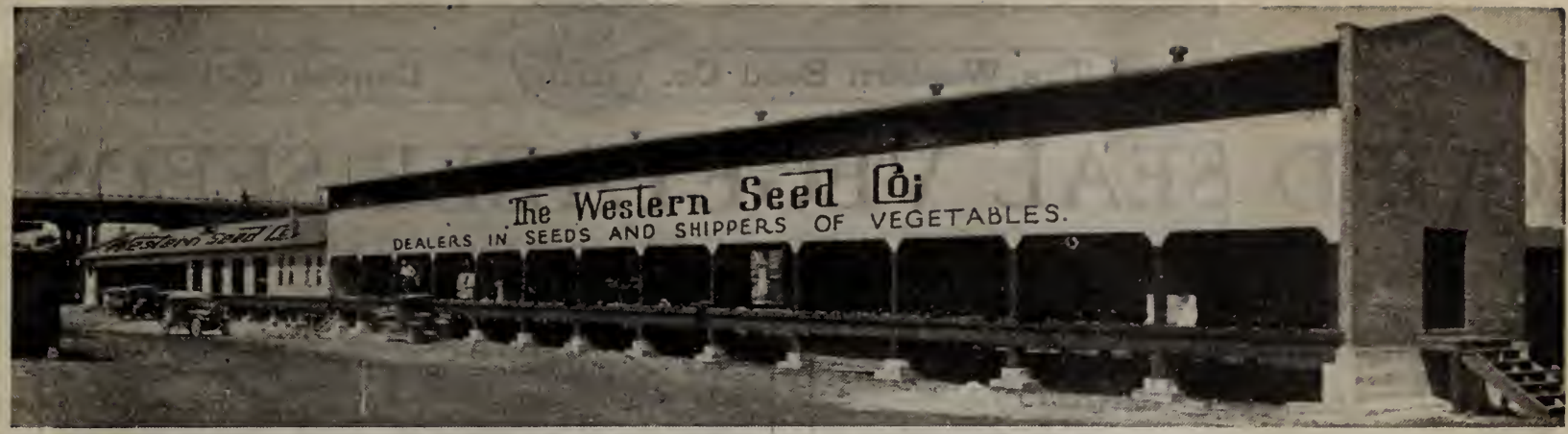

One of Our Vegetable Packing Warehouses where Hundreds of Cars of Vegetables are Bought and Shipped by Us

\section{Why You Can Buy and Plant With Confidence Our Gold Seal Seeds}

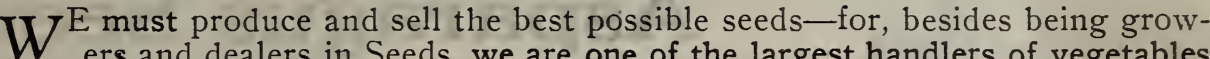
in the United States.

The past season we bought and shipped over 2000 carloads of vegetables. We operate in all the leading growing districts in Colorado and California and we make it a point when buying to give preference to produce grown from our seeds. In this way we are best able to judge the kind of crops that are grown from our seeds; so you can readily understand why we are so desirous of selling only the very best; for if we sell poor seed, the crop which is offered us will be an inferior grade.

Thus it is to our own interest to sell only the very finest seeds, for in return, at shipping season we are able to offer our trade fancy vegetables and obtain better prices.

For these reasons we spare no care or expense in the production of Gold Seal Quality seeds. There has never been a disappointment in Gold Seal quality. In producing the seed we sell, cost is no consideration. Our aim is to produce the best-in fact, we must produce and sell the best quality seed.

Every lot of Vegetable, Flower and Field Seed we send out is also tested for germination by us shortly before they are sent out.

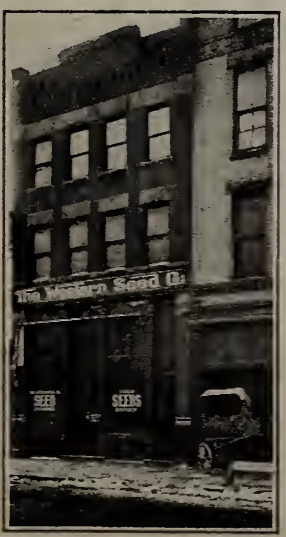

\section{Our Guarantee}

Our seeds are sold to you with the express understanding that if they are not as represented and not fully satisfactory when you receive them, we will take them back and CHEERFULLY REFUND YOUR MONEY. But as there are so many outside influences over which we have no control - such as weather conditionswe cannot guarantee a crop.

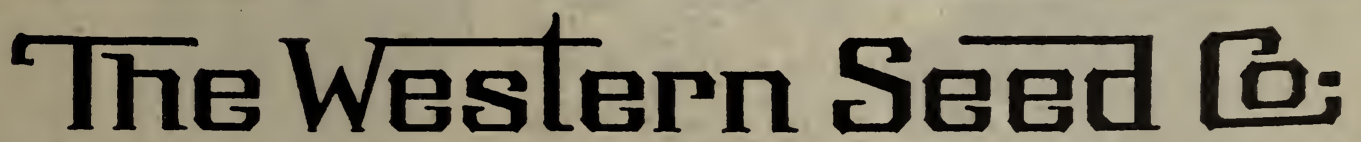

ELMER HARTNER, President - DENVER, COLORADO - R. E. PATTERSON, Mgr. 


\section{GOLD SEAL VEGETABLE SEEDS}

For many years the high quality of our vegetable seeds has been known to the majority of planters and they buy and plant Gold Seal Seeds confident that they are as represented.

\section{Mountain Head Lettuce, Peas and Cauliflower}

The growing of these crops in our Mountain Districts has now become a permanent industry that has proved and will prove profitable for many and disastrous for some. Proper care and study in the selection of the ground and its accessibility and a knowledge of how to plant and handle the crop are necessary, besides a good grade of seed. Don't be fooled into buying cheap lots of seed from irresponsible parties.

\begin{abstract}
Garden for Health as Well as Profit
The home garden should not only be viewed from a point of profit and saving, but greater benfits by ten times are derived from the standpoint of health.

Either fresh fruits or vegetables should be in daily use in every home. They constitute not only a delicious and appetizing food, but as science has proved-a food indispensable to health. While to the majority of us fresh fruits and vegetables are not a part of our daily diet, due to being out of season or too remote from source of supply, yet almost everyone can produce their seasonable needs with little expense from their own garden.
\end{abstract}

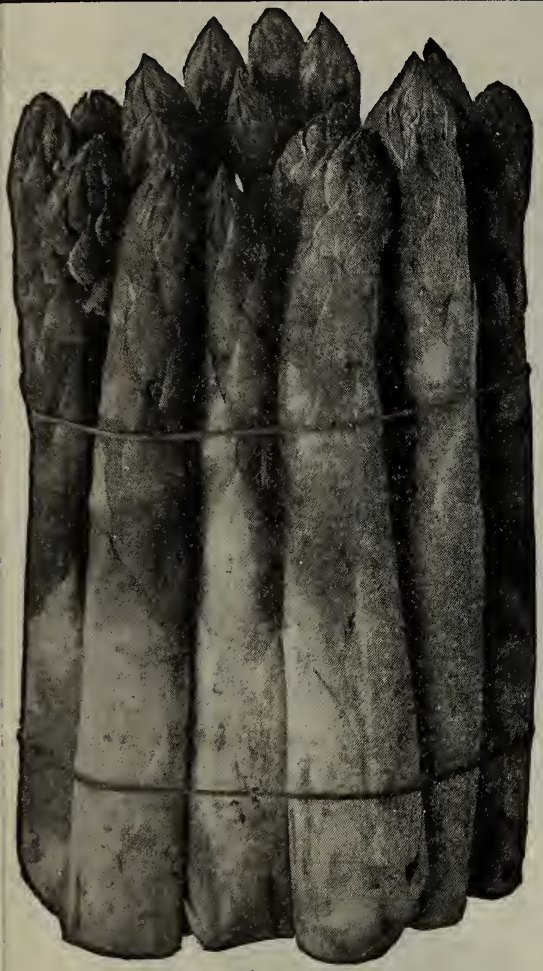

Mary Washington Asparagus.

\section{Asparagus Seed}

ASPARAGUS CULTURE. Plow your plot deep, then loosen up your soil, making a perfect seed bed. Sow your seeds thick in rows 20 to 24 inches apart. Use plenty of water for the seed has a hard hull that can only be softened with moisture. After the plazints start growing you must not cultivate, as this will injure the roots, and these roots a re needed to produce the wholesome, crisp asparagus that is served on your table. (The 1 in are what you grow from the seed). The following Spring the roots must be dug, epeach following year. As the roots get older and larger the asparagus comes thicker better. If you do not care to wait and raise your own roots we can supply you with. or two-year-old roots of any variety listed.

MARY WASHINGTON. The Department of Agriculture have developed two strains of Washington Asparagus; that is Maxtha Washington and Mary Washington, but the latter has proven to be the most highly rust resistant, and most hardy and productive of the two. hardy and productive of the two. The shoots are long, straight, thick,
and heavy; dark green the entire length, except tinted darker at the tips. Pkt., 10c; oz., 25c; $1 / 4$ lb., 80c; lb., \$2.50, postpaid.

EARLY GIANT FRENCH ARGENTEUIL (Gold Seal Quality). This early variety was first imported and sold on this market by us. Its superior quality has placed it ahead of all others. Dark green large shoots, far more productive than the old sorts, which makes it preferred on all markets. Pkt., 5c; oz., 10c; $1 / 4$ lb., 30c; 1 lb., 85c, postpaid.

PALMETTO. This has been the most popular variety for genera gardening purposes. Matures early, very prolific, producing an abundance of deep green shoots. Pkt., 5 ; ; oz., 10c; $1 / 4$ lb., 25c; lb., 80c, postpaid.

GIANT SNOW CAP. While the green varieties of Asparagus are very popular in most sections, this is largely due to the fact that the white varieties heretofore have been small and somewhat tough. But in this new introduction, Giant Snow Cap, we offer a large white, tender, prolific sort which will find favor even with the growers who are partial to the green varieties. Pkt., 10c; oz., 20c; $1 / 4$ lb., 50c; lb., $\$ 1.75$. ASPARAGUS ROOTS. See page 42.

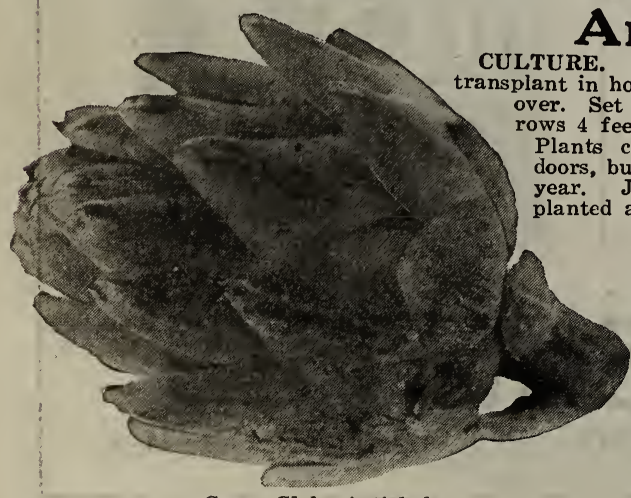

\section{Artichokes}

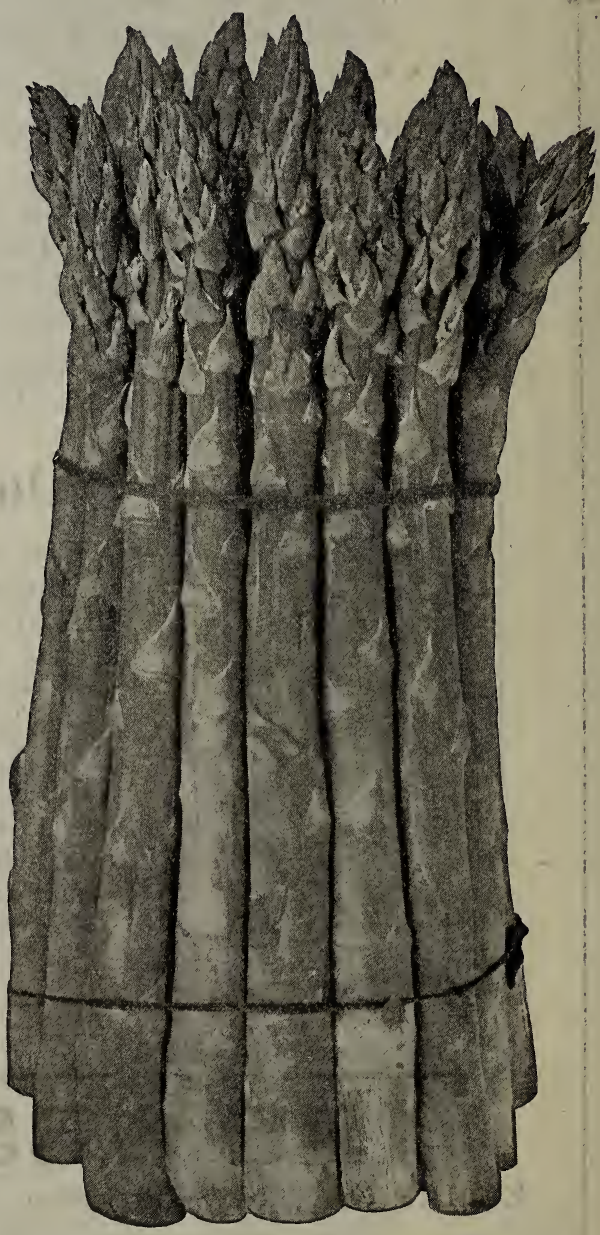

Early Giant French Argenteuil Asparagus. 


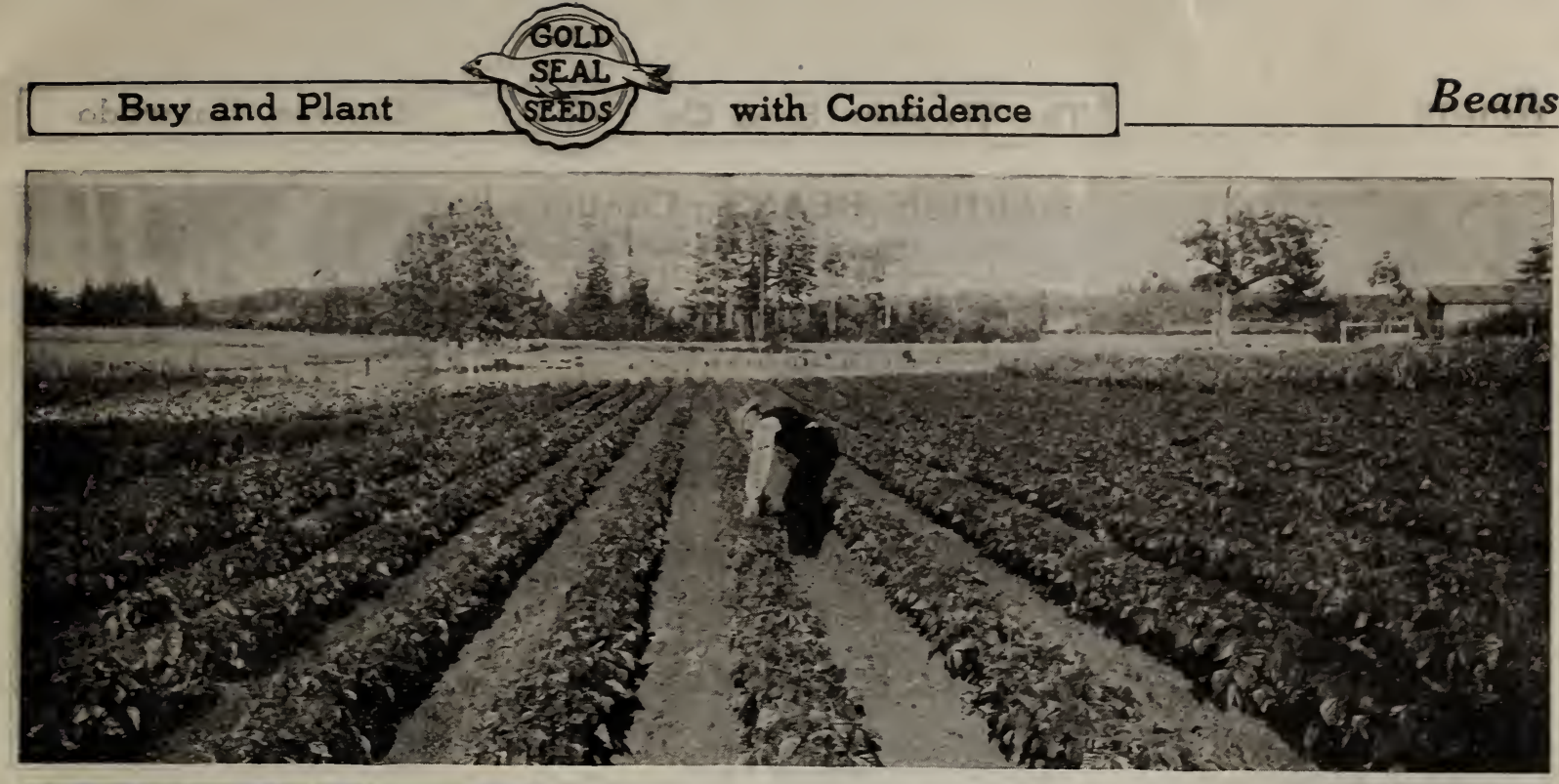

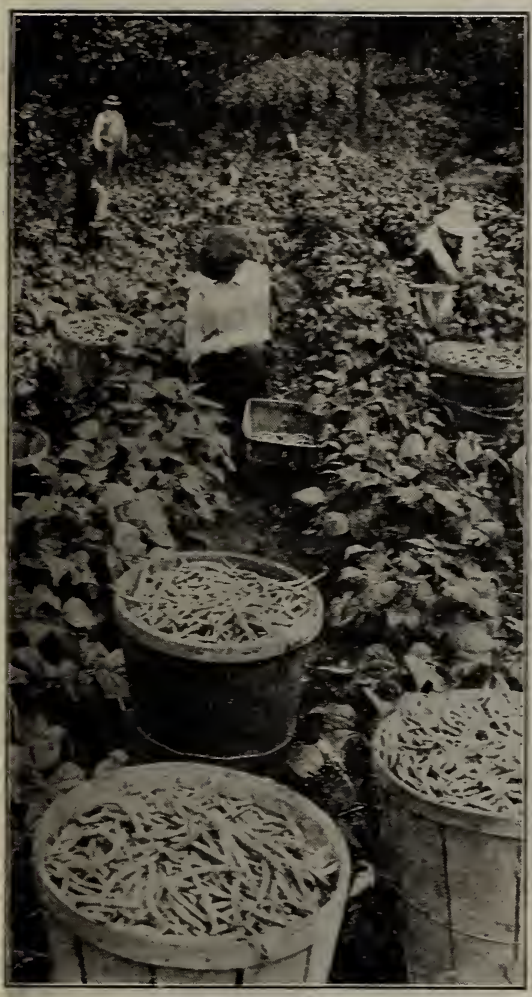

Full Measure Beans.

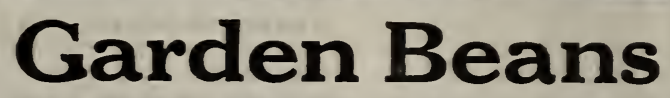

CULTURE. There is hardly a vegetable that contributes to the table as liberally as the snap bean. It is easy to grow and a heavy producer. Beans should be planted at intervals so that one may always have a fresh patch to depend upon.

For the best crops beans require good rich soil and frequent hoeing. The roung plants are very tender and cannot withstand even slight frosts. The seed should not be planted until the soil has become well warmed and all danger of frost is over. Spade or plow deeply and plant in rows 2 feet apart, scattering the seed about 3 inches apart in the row, and cover 2 inches deep. Hoe frequently, but never when the foliage is damp from dew or rain. Hoeing should be done shallow so that the roots are not injured.

\section{Green Podded Varieties}

FULL MEASURE (Gold Seal Quality). While this is not a new variety, yet it is just being recognized as one of the finest beans that can be grown, because besides being absolutely stringless, the shell or skin of the pods does not get tough, no matter how long the pods are allowed to remain on the bush. The texture of the pod never grows coarse, but remains tender and meaty until the bean is fully matured and ready to shell. Due to its fine quality and long pods, in the past 4 sears it has become the leading and most satisfactory bean, both for local use and as a shippin variety. It is superior to Burpee's Stringless.

SHIPPERS' GREEN POD or LONGFELLOW. This is the bean planted so extensively by our market gardeners, as it produces a large crop of pods which find a ready sale to the shippers at an advanced price. It is an excellent keeper; better than the Burpee's Stringless or Refugee. The pods are long and straight and of a dark green color. When the pods are young they are absolutely stringless, very tender and of highest flavor-even excelling the old standard, Burpee's Stringless.

GIANT STRINGLESS. Exceedingly productive and very hardy. Matures a few days later than the Burpee's Stringless, but is slightly longer and more nearly straight.

BURPEE'S STRINGLESS. The most popular bean grown, because it is almost stringless, of dwarf growth, plants very productive, quite early, pods cylindrical. Especially recommended for home gardens.

EARLY SIX WEEKS. This is a very productive bean; pods are long, about 5 inches, straight, handsome, rather light green and when soung are of a good quality. This is early maturing and is much used for home gardens.

EXTRA EARLY REFUGEF. A very early round podded sort, having medium sized, fleshy pods. Vines small and very productive; for early planting this is one of the best sorts.

RED VALENTINE. This is an old well known rariety, very productive. Pods are long oreen, straight and perfectly round. The quality is also good, pods being decidedly tender. Suitable for early and late planting, being extremely sturdy.

\section{PRICES-GREEN PODDED VARIETIES}

Postpaid, pkt., 5c; large size package, 10e; $1 / 2 \mathrm{lb}$., 20c; $1 \mathrm{lb}$., $35 \mathrm{c} ; 5$ lbs. $\$ 1.50 ; 10$ lbs, $\$ 2.50$. If by express or freight at purchaser's expense, 5 cents per pound less. $100 \mathrm{lbs}$., $\$ 18.50$.

\section{Wax Podded Varieties}

ROUND POD KIDNEY WAX-BRITTLE WAX. A very handsome midseason variety, especially desirable for snaps for home garden. The plants are of strong growth, spreading and very productive.
The leaves are large, broad, and roughened. The pods are long and round, $51 /$ to 6 inches, slightly curved, light jellow, wax-like, stringless and of the very best quality. Seed long, cylindrical, medium sized, nearly white with a little dark markings about the eye. We especially recommend this bean for
the gardener-it is also an excellent shipping variets.

PENCIC POD BLACK WAX. Pods are long, thick, and fleshy and stringless,

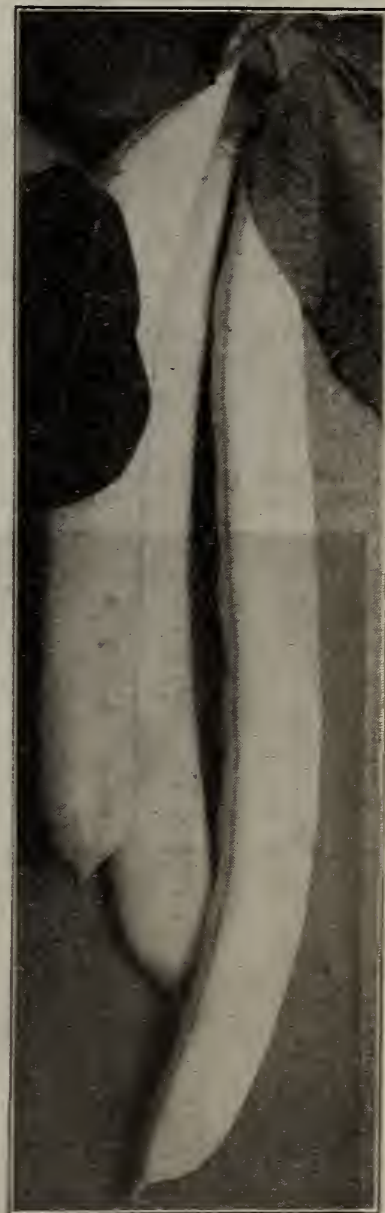

Round Pod Kidney Wax Beans. 


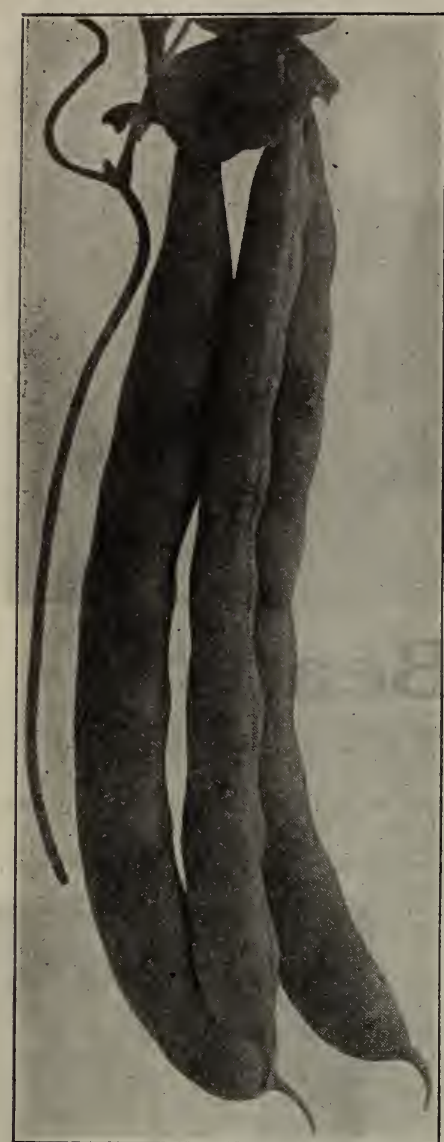

\section{GARDEN BEANS-Continued}

DAVIS WHITE WAX. A white-seeded Golden Wax Benn of superior quality, extremely early and of great productiveness. The plant grows larger than the Golden Wax and produces an abundant crop of large, meaty, flat pods, which are of a bright golden-yellow color, exceedingly attractive and very uniform in size and shape.

CHALLENGE DWARF BLACK WAX. This bean is a favorite among the growers who grow beans for the early market, as it is the earliest of the round wax varieties. The vine is strong, holding the pods well up, which are of a nice bright yellow color.

GERMAN BLACK WAX. Vines medium size with small foliage, very vigorous, hardy, and productive, maturing about midseason; pods are medium length, borne well up from the ground, are curved, cylindrical, fleshy, and of a cream white color. It remains a long fleshy, and of a cream white color.
time in condition for use as snaps.

OLD-FASHIONED GOLDEN WAX. This bean is the grand old wax-podded variety that has been planted by gardeners, both large and small, for many years. It is a heavy producer and very seldom fails to givo It is a heavy producer and very seldom fails to givo fail. The pods are long and semi-round, of rich golden cream color, very meaty and tender.

IMPROVED GOLDEN WAX. One of the old popular varieties; pods straight, flat, and golden in color.

SHIPPERS' WAX POD. Pods long, round, straight, thick, and absolutely stringless. This variety has proved the best shipper, and we cannot recommend it too highly to market gardeners. It holds up well and is of fine appearance.

PRICES-WAX PODDED VARIETIES

Postpaid, pkt., 5c: large package, 10c; 1/, lb., 20c; 1 lb., 35c; 5 lbs., \$1.50; 10 Tbs., $\$ 2.50$. If by express or freight at purchaser's expense, 5c per pound lesk. $100 \mathrm{lbs} ., \$ 19.00$.

Kentucky Wonder Pole Beans.

\section{Pole Beans}

KENTUCKY WONDER (Green Pod). This standard variety of Green Podded Pole Beans became popular through its rapid growth and abundant yielding qualities. It has been successfull grown in every section of the United States. Being extensively used as a corn bean, the pods are exceptionally long and often measure 10 to 12 inches, perfectly round and stringless when young. A good sort to plant around fences, for it will climb and completely cover them in a short time. If allowed to ripen and dried, beans are grood for winter use Price, postpaid. Plth $5 c$ dried, beans are good for a $1 /$ s. $10 \mathrm{lbs}, \$ 3.00$. If by express or freight, purchaser paying charges, $5 c$ per pound less.

LAZY WIFE. Green podded, very productive, and later than other varieties. Postpaid, pkt., $5 \mathrm{c}$; large size package, $10 \mathrm{c} ; 1 / \mathrm{m} \mathbf{l b}$. $20 \mathrm{c} ; 1 \mathrm{lb} ., 35 \mathrm{c} ; 5 \mathrm{lbs}$., $\$ 1.60 ; 10$ lbs., $\$ 3.00$. If by express or freight, purchaser paying charges, $5 \mathrm{c}$ per pound less.

KENTUCKY WONDER WAX (Pole). The best wax podded pole bean. Vines are strong, producing pods 6 to 8 inches long, coming in very abundant clusters, pods very broad, thick, and fleshy, of golden yellow to creamy white. Postpaid, pkt., 5c; large size package, 10c; 1/ lb., 20c; 1 lb., 35c; 5 lbs., $\$ 1.60 ; 10 \mathrm{lbs}$. $\$ 3.00$. If by express or freight, purchaser paying charges, $5 \mathrm{c}$ per pound less.

\section{Shell Beans}

DWARF HORTICULTURAL (Shell Beans). Very productive, vines compact, upright, with large leaves, pods medium length, round, curved, yellowish color, marked with splashes of red. The beans are fit for use
Henderson's Bush Lima Beans,

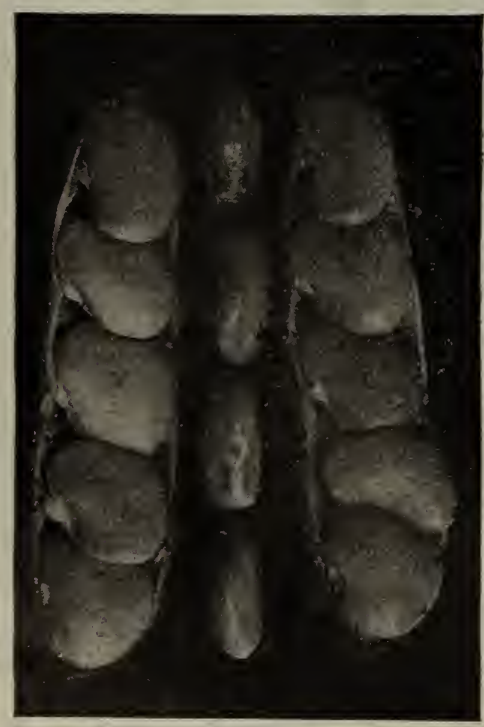
as green shell beans, very early, and in this condition the beans are very large and easily shelled, and are about equal to Lima Beans in quality. Postpaid, pkt., 5c; large package, express or freight, purchaser paying charges, $5 c$ per pound less.

\section{Lima Beans}

HENDERSON BUSH LIMA. This is the earliest of the flat-pod limas and is much more satisfactory to grow in districts which have about the same climate as Denver. It is two weeks earlier than any other variety. They resemble the Burpers earlier than any other variety. They resemble the Burpee's in flavor and shape, but are only about one-third as
large. As dry beans they are known as Baby Lima. Postpaid, pkt., 5c; large package, 10c; $1 / 2$ lb., 20c; 1 lb., 35c 5 lbs., $\$ 1.50 ; 10$ lbs., $\$ 2.50$. If by express or freight at pur chaser's expense, $5 c$ per pound less.

AZTEC (Colorado or California Cream Butter). This wonderful bean has been grown for generations in New Mexico by the Indians. It is the Lima Bean for the Western territory ; does well on dry land, and is earlier than other varieties. The seed is not flat like most Lima Beans, but round and about the shape of our small Navy Bean, but is 4 or 5 times larger. Can be used either as a green shell bean or dried. Postpaid, pkt., 5c; large package, 10c; 1/2 lb., 25c; 1 lb., 40c; 5 lbs., $\$ 1.75 ; 10$ lbs., $\$ 3.00$. If by express or freight, at purchaser's expense, $5 \mathrm{c}$ per pound less.

BURPEE'S BUSH. The old standard Bush Lima Bean. The bushes are 18 to 20 inches high, of stout, erect growth; branch freely and are very prolific. The pods are well filled with large, fleshy beans of excellent quality. Delicate pale green in color and possessing that rich, buttery flavor of the green in color and possessing that rich, buttery flavor of the pole variety. Postpaid, pkt., 5c; large package, 10c; $1 / 2 \mathrm{lb}$, freight, purchaser paying charges, $5 c$ per pound less,
Inoculate Your Beans with Nitragin. (See page 87 ).

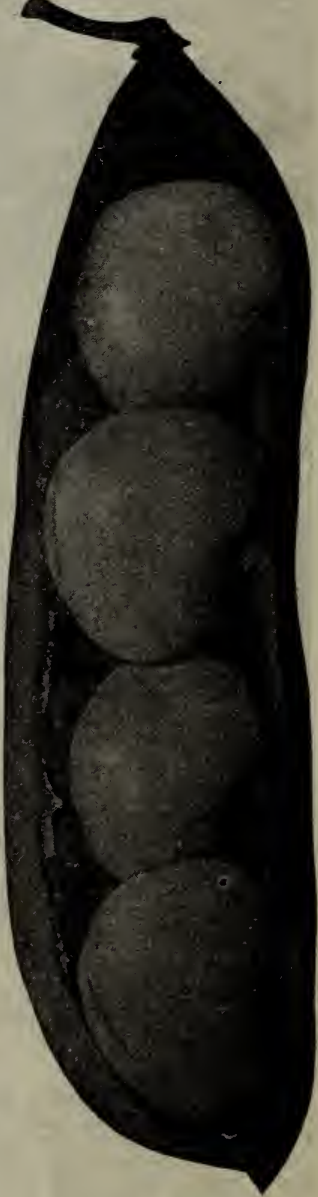

Burpee's Bush Lima Begng, 


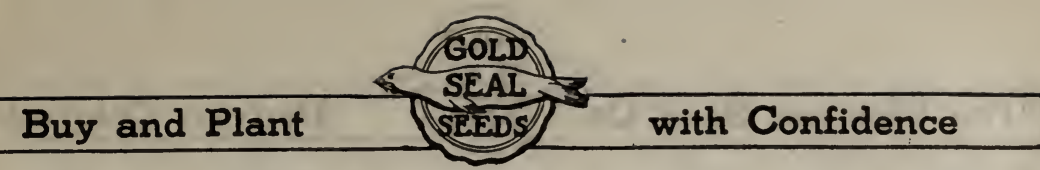

- 


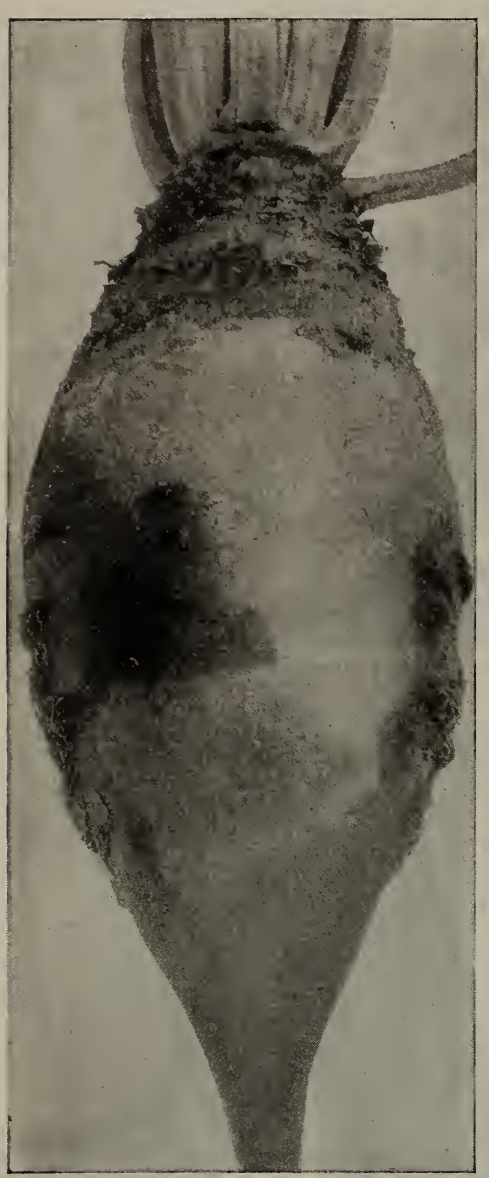

Danish Sludstrup Mangel.

\section{Beets for Stock'Feeding}

\section{Splendid Winter Feed for Cattle, Hogs, Poultry,} Sheep, Etc.

\section{Our Seed is Danish Grown-Buy No Other}

An ever-increasing acreage is being planted to stock beets, because of the wonderful result obtained by feeding them. Fattening, milch and breeding cattle do equally well on them About one-fourth of the daily rations should be of roots. . Hog cholera is prevented by their use.

We are very careful in the selection of our Mangel Seed. There is a great difference in this seed. The seed we offer has been bred up to the highest type with an aim to produce a beet that contained the highest perentage of fattening matter and the least water.

CULTURE. Both Mangels and Sugar Beets require deep, well enriched soil. Sow in May and June in rows 18 inches to 2 feet apart and 6 to 8 inches in the row. Young plants may be transplanted to fill up vacancies. As soon as frost occurs, dig the crop. For Winter store in cellar or in pits.

\section{SUGAR BEETS}

Prices, all varieties, postpaid: Pkt., 5c; 1 oz., 10c; 1/4 lb., 20c; 1 lb., 45c; 5 lbs., $\$ 2.00$ $10 \mathrm{lbs} ., \$ 3.50$. If by express or freight, purchaser paying charges, $5 \mathrm{c}$ per pound less. For larger a mounts, see Blue List.

VILMORIN'S IMPROVED WHITE. Medium size, brought by careful selection to the highest perfection in shape and color of roots. Greatly esteemed by sugar manufacturers and on of the finest for stock feeding.

WANZLEBEN. This is the variety so extensively planted for sugar manufacture. Although it does not yield quite as large crops as mangels, the feeding value, pound for pound, is much greater on account of its high percentage of dry matter content. Recommended especially for fattening cattle, matter content. Recommended especially for fattening cattle,
but is equally well adapted for general feeding as mangels.

\section{MANGEL WURZELS}

Prices, all varieties, postpaid: Pkt., 5c; 1/4 lb., 15c; $1 \mathrm{lb}$., $45 \mathrm{c} ; 5$ lbs., $\$ 2.00 ; 10$ lbs., $\$ 3.50$. If by express or freight, purchaser paying charges, 5c per pound less. For large amounts, see Blue List.

DANISH SLUDSTRUP. Contains more feeding value than any other mangel. The roots are large, reddish yellow, of distinct type and a remarkable yielder. Tests show it to contain as follows:

17 per cent more pounds of roots per acre than the Mammoth Long Red.

23 per cent more nutriment than the Mammoth Long Red. 22 per cent more pounds of roots per acre than the Golden Tankard.

28 per cent more nutriment than the Golden Tankard.

Over 40 tons have been grown on a single acre.

GIANT HALF SUGAR. This is neither a mangel nor a sugar beet, but as the name implies is a cross between the two. It has the large size of the mangel with the great feeding quality of the sugar beet. It will yield almost as many tons per acre as the best mangels, twice as much as the sugar beet. It has become the most popular beet grown for stock feed. As all grains are now higher, more stock beets should be planted.

GOLDEN TANKARD. The best known and highly recommended for dairymen on account of its milkproducing properties and the rich quality of the milk. The flesh is firm and solid and a rich golden yellow color. On account of its peculiar shape they can be grown closer in the rows than most mangels, increasing the yield per acre considerably. Grows well above the ground and is easily pulled. Yields particucreasing the yield per
larly well on light soil.

GIANT ECKENDORFER. A very popular variety, grown extensively in Germany. It has also proven very satisfactory in the United States wherever it has been tried. Its roots are very heavy. It has been known to produce as much as 55 tons of roots to the acre. This variety is very easily harvested, as a large portion grows above the ground.

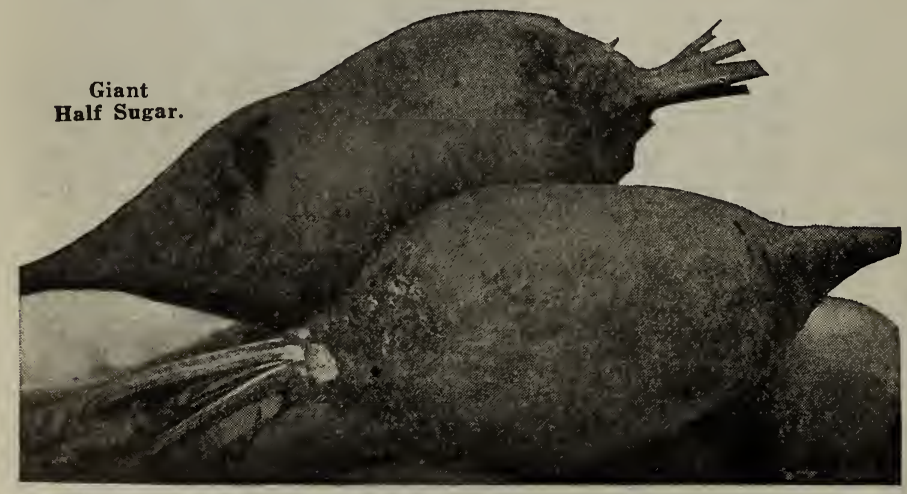

MAMMOTH LONG RED. This is a very large and heavy mangel Roots grow one-half to two-thirds above heavy mangel. Roots grow one-half to two-thirds above the soil and are often two or more feet in length and nine
inches in diameter. Skin dark red, flesh white, with veined rings of pink.

\section{SWISS CHARD}

GREEN LEAF. This member of the beet family is grown for the leaves only, and cooked like spinach. The mid-rib is prepared like asparagus. It is hardy and productive, with broad green legves and large white midribs or chards of excellent quality, and can be sown at different seasons of the year, giving successive greens. Pkt. ent seasons of the year, giving suc.

LUCULLUS. A peculiarly delicious variety having green leaves which are remarkably crimped and curled,
like savoy-leaved cabbage. The chards are white and like savoy-leaved cabbage. The chards are white and equally fine in flavor. Pkt., 10c; oz., 15c; 1/4 1b., 35c; $1 \mathrm{lb} ., \$ 1.00$. 


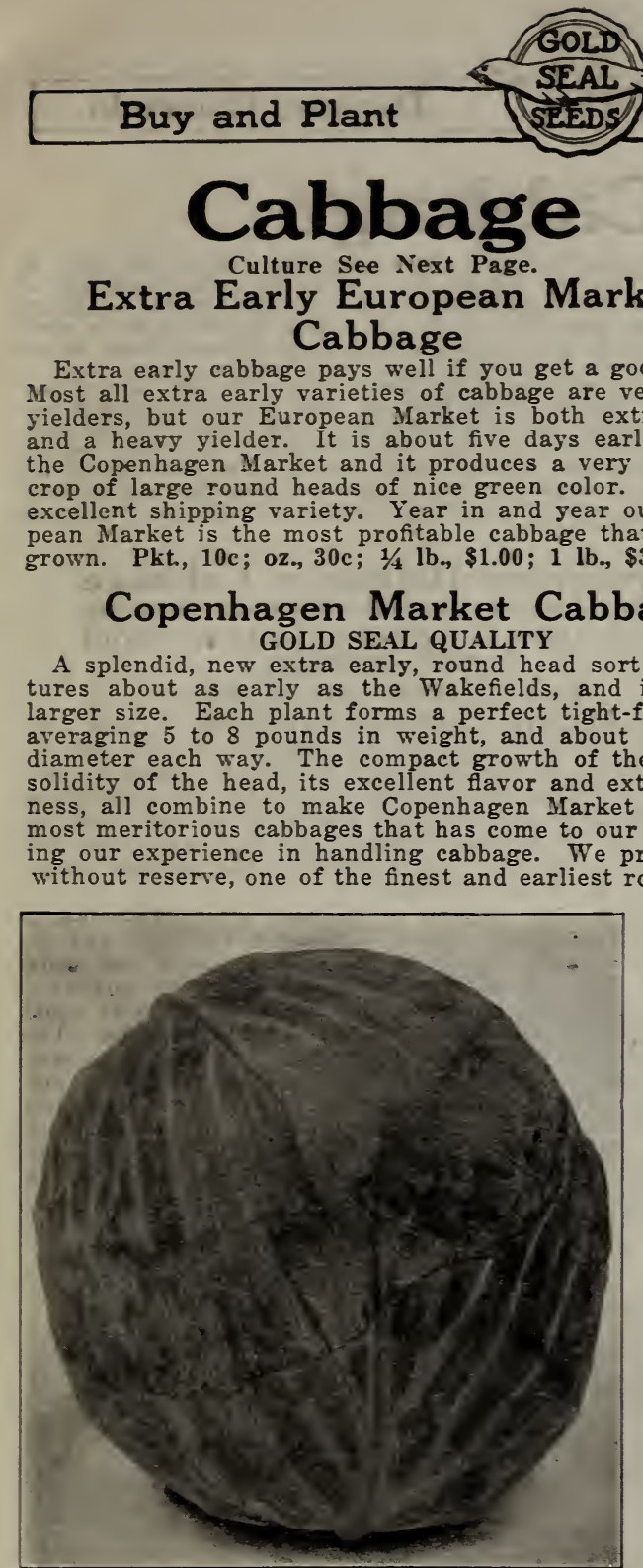

Mxtra early cabbage pays well if you get a good yield. 列 and a heavy the Copenhagen Market and it produces a very uniform crop large round heads of nice green color. It is an pean Market is the most profitable cabbage that can be grown. Pkt., 10c; oz., 30c; 1/4 lb., \$1.00; 1 lb., \$3.50.

\section{Copenhagen Market Cabbage GOLD SEAL QUALITY}

A splendid, new extra early, round head sort which olant, the to make Copenhagen Market one of the metice durin our experience in handling habage We pronce it sorts in cultivation today.

It is very popular with the market gardeners. It is a short-stemmed variety, the heads nearly resting on the ground. It is very desirable on account of the characteristic of maturing the heads all at the same time, thus enabling the grower to clean his fields at the first cutting. Heads are large, very solid, and of the most excellent quality. Gold Seal Quality. Postpaid, pkt., 10c; 1 oz., 30c; $1 / 1 \mathrm{lb}, 90 \mathrm{c} ; 1 \mathrm{lb}$, $\$ 2.75$.

\section{Golden Acre Cabbage}

The Golden Acre is a new superior variety of early, round-headed cabbage, very closely resembling Copenhagen Market, but more fixed in type. It has qualities so valuable and important that, not since the advent of the "Jersey Wakefield" has a greater or more important Early Cabbage been offered.

We believe it is the earliest cabbage in existence. It matures in but 80 days from the date the seed is sown. The head begins to form when the leaves are no larger than a saucer and its growth may be observed almost from day to day. It is perfectly round and, full grown, measures 8 to 12 inches in diameter. The heads mature all at the same time-so fixed is the type, and one head is just like the other.

The plants can be set very close, as there are only about 12 leaves and these are very short. The stalk is less than two inches high, so that the plant is distinctly dwarf.

Seed grown by originator: Pkt., 15c; oz., 60c; $1 / 4$ lb., $\$ 2.00 ; 1 b ., \$ 6.50$. Holland grown seed: Pkt., 10c; $1 / 2$ oz., $25 \mathrm{c} ; 0 \mathrm{z} ., 45 \mathrm{c} ; 1 / 4 \mathrm{lb} ., \$ 1.25 ; 1 b ., \$ 4.00$.

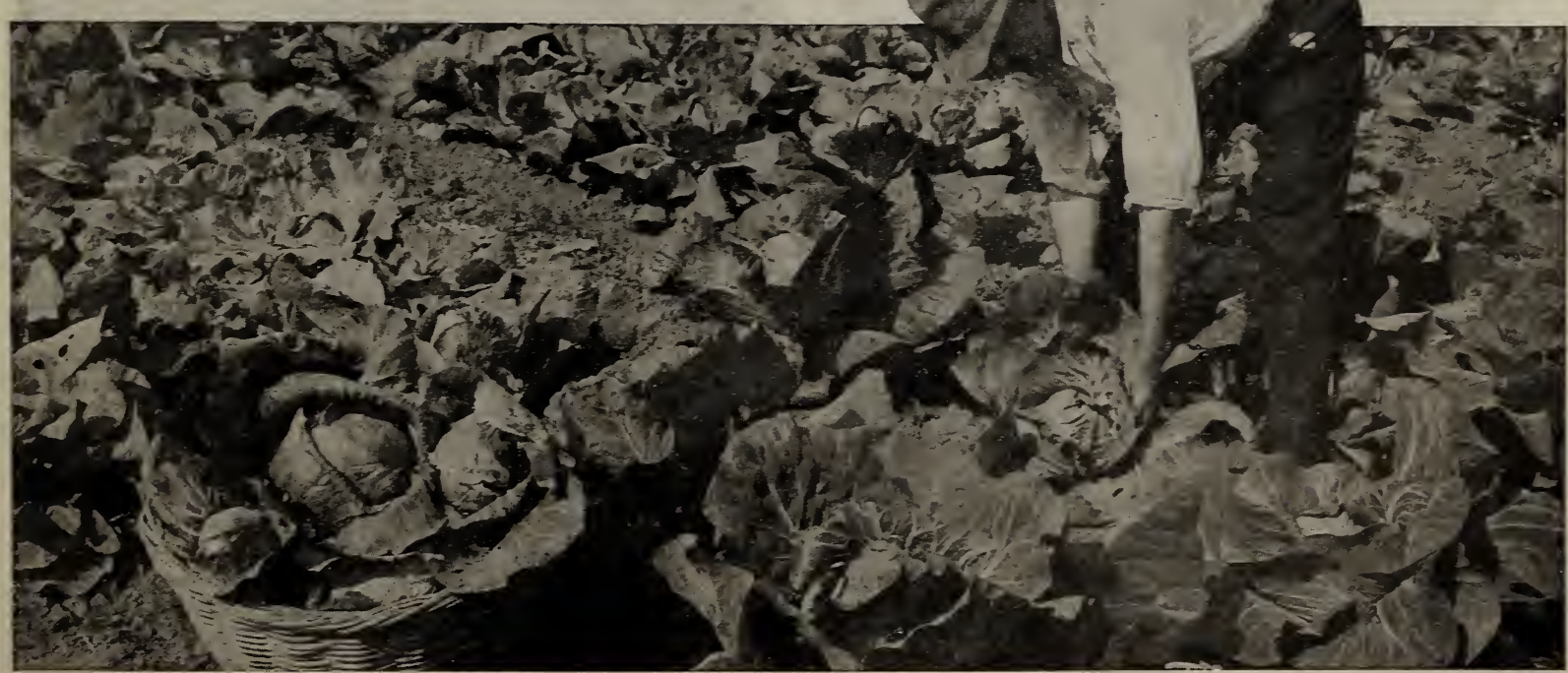




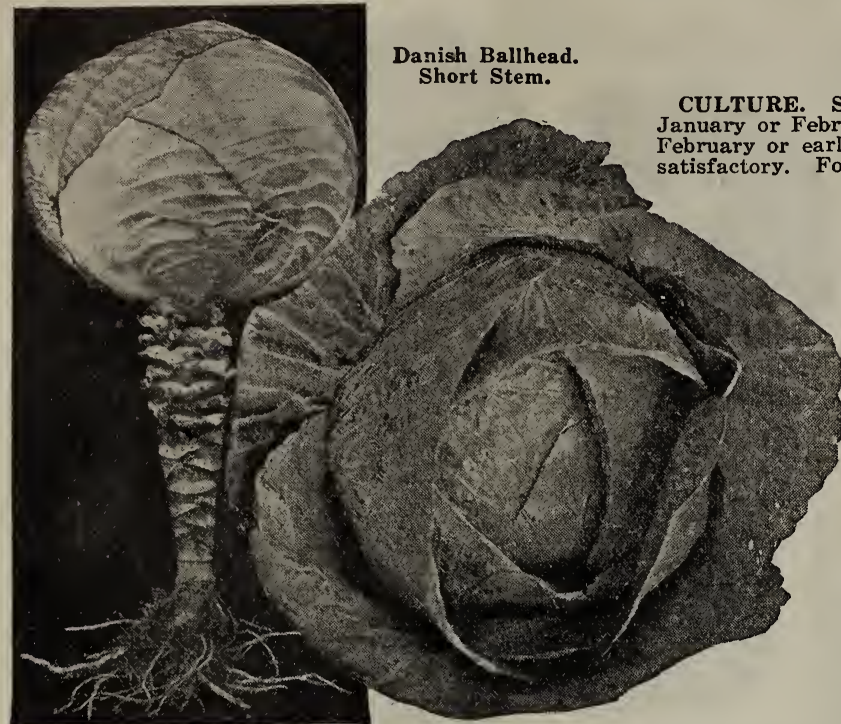

\section{Cabbage}

Start with good seed. For extra early use, seed may be sown in or February very thinly in hotbeds-for medium early, start seeds last of

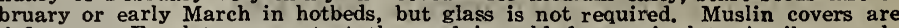
For late crop, start the seed in cold frames in late April or early May and not over one-fourth inch deep. Plants should be set in rows $21 / 2$ to 3 feet apart and 12 to 18 inches in row.

Of recent years a very satisfactory method has been to sow the seed right out in the field, the same as sugar beets and thin after the plants get three inches tall. This is much cheaper than growing in beds, and then transplanting to the fields, besides the plant is not retarded in its growth after being set to the field. While we sell cabbage plants, yet we advise you to grow your own, as transportation from one locality to another is never so satisfactory.

\section{Evergreen Hollander Cabbage \\ Original Strain-Sold Only in Sealed Packages \\ COLORADO'S MOST POPULAR LATE SHORT STEM CABBAGE}

Plant No Other-Buy No Other

EVERGREEN HOLLANDER CABBAGE. Is our own origination and we control the strain. It can only be secured from us and then only in sealed packages bearing our Gold Seal trade mark. If you buy this seed from us and with proper care and attention, do not raise the finest crop of Holland Cabbage you ever grew, we will refund your money. You cannot get the genuine strain except in Gold Seal packages.

EARLY JERSEY WAKEFIELD. For many years or until Copenhagen Market was introduced this was the leading early cabbage; a very satisfactory sort where an early, pointed head is desired. Pkt., 10c; oz., 25c; $1 / 4$ lb., 80c; 1 lb., $\$ 2.00$.

DANISH ROUNDHEAD, SHORT STEM (Gold Seal Quality). The Cabbage Grower's Friend. One of the grandest of all cabbages, and it is now more extensively grown throughout the United States than any other variety, and one year after another it has given the cabbage growers wonderful results. This one variety alone has done more to place Colorado among the leading cabbage states in the Union than all other varieties combined. It is just 16 years ago that this firm persuaded the growers of cabbage to try this variety instead of the old-fashioned Holland, the Drumhead and the Flat Dutch. The Danish Roundhead Short Stem never fails to produce a good crop of cabbage. This variety is inclined to grow on a very short stem and

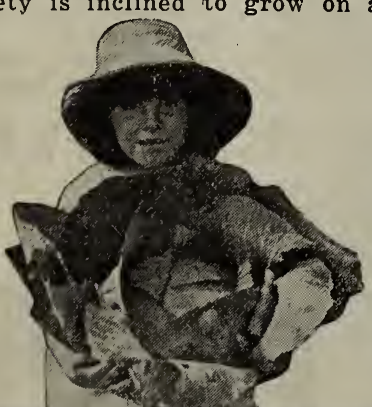
roduces rounded heads of a dark green color. When the seed is sown in the open, it matures about the last of September, while in the dry hot seasons it will mature about 2 weeks earlier. Recommended by us as a good heavy yielding main crop cabbage. Postpaid, pkt., 10c; 1 oz., 25c; $1 / 4$ lb., 80 c; 1 lb., $\$ 2.50$.

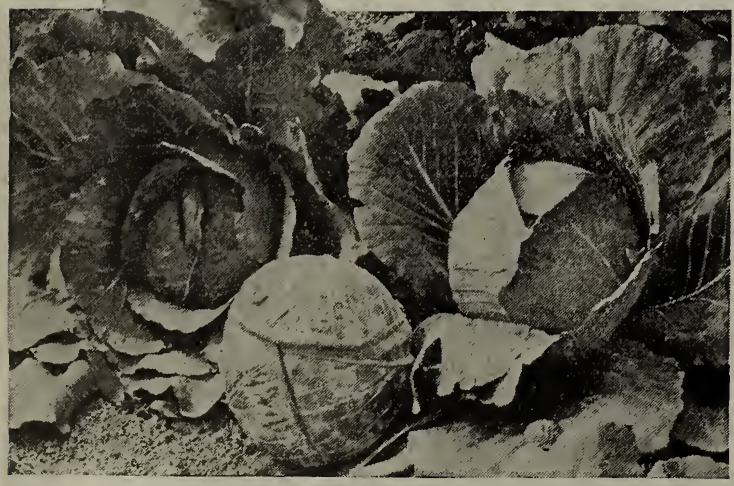

Danish Round Head Short Stem.
Our experience, as a shipper of cabbage and vegetables, is that our Evergreen Short Stem Hollander Cabbage has no equal, and as we handle thousands of tons annually, our word may be relied upon. Evergreen Hollander excels in qualitythe heads are uniform, solid, heavy, and crisp. It will equal and outyield all other varieties under similar conditions. The instance has been known where twenty tons per acre was secured from good, strong ground with proper attention and handling. It has wonderful keeping qualities, and consequently is much sought after by carlot shippers. The rich, green color of the heads is retained as long as they exist. We have seen Evergreen Hollander taken out of pits as late as March 5th and the heads were as green as when buried. Prices, postpaid: Pkt., 10c; oz., 25c; 1/4 lb., 75c; 1 lb., \$2.50.

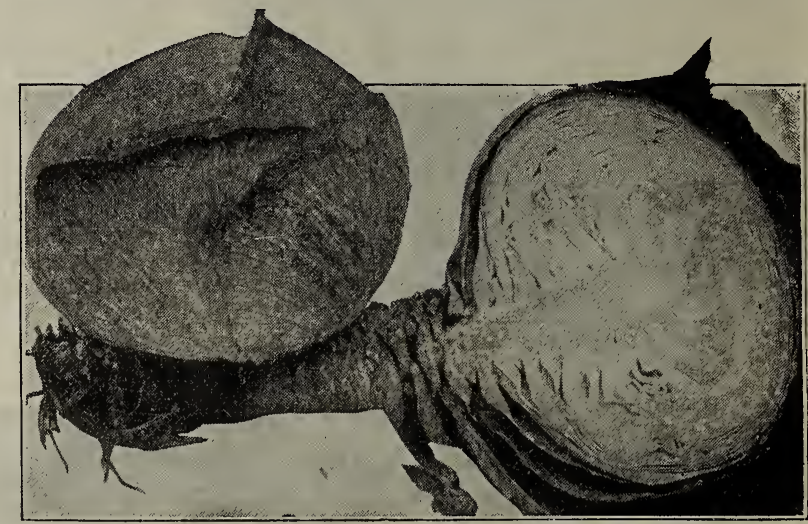

Evergreen Hollander.

GLORY OF ENKHUIZEN. It is considered an early variety, being ready for market just after the Copenhagen Market It is a very heavy yielder and one of the best sorts for Kraut making. The seed we offer is the Gold Seal Strain, which means there is none better.

Glory of Enkhuizen has a better flavor than any other cabbage grown, and as it is extra early produces a heavy yield of good sized heads, making it a favorite among cabbage growers wherever grown. Planted side by side with the Early Jersey Wakefield, and conditions the same, Enkhuizen will mature a little later but will yield double, which makes it the most profitable second early cabbage. Enkhuizen Cabbage will produce on most any soil, and does not require the attention demanded by other varieties. It will stand the drought better than any other cabbage known to us.

For midseason cabbage, both for the gardener and the home lot, we highly recommend the above. Postpaid, pkt., 10c; $10 z$. 30 c; $1 / 4 \mathrm{lb}$., 80c; 1 lb., $\$ 2.50$. 


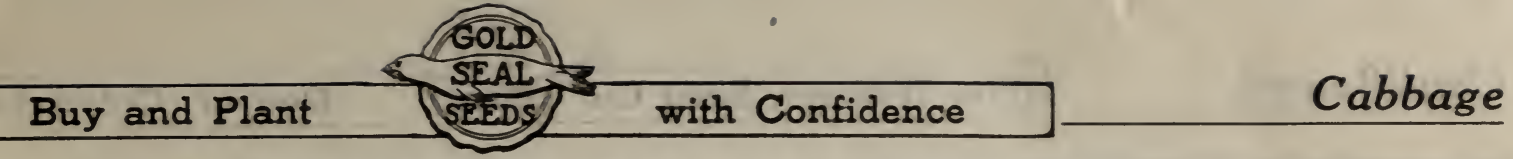

\section{Cabbage}

DANISH BALLHEAD SHORT STEM (Gold Seal Quality). A new type of cabbage introduced by us ten years ago and readily accepted by those who tried it as a very desirable sort for the late kind that can be put in the ground for midwinter use. If planted on good ground an enormous yield can be expected, for the heads, when matured, are all of a good size and very solid; it shows its good breeding by the bluish tints in the reins. Highly recommended as one of the best late Hollander cabbages and we predict that in the future it will be grown more than any other sort. It matures between the Danish Roundhead, Short Stem and the Danish Ballhead, Long Stem. Postpaid, pkt, 10c; 1 oz, 25c; $1 / 4 \mathrm{lb}, 80 \mathrm{c} ; 1 \mathrm{lb}, \$ 2.50$.

EARLY WINNIGSTADT (Gold Seal Quality). The old, reliable, well-known, standard cabbage for the market garden. A farorite among growers who have good, rich land. It always meets with ready sales on account of its fine appearance. The heads are pointed, compact, hard, of rich green color and uniform in size, making it a very desirable shipping cabbage. Many growers plant Winnigstadt for their main crop to sell to the shipping trade, who demand a medium-sized, green cabbage that will stand handling. Winnigstadt can be planted closer in the rows than other types, for its growth is upward to a point instead of spreading and round. If planted close on good ground a heary rield is assured, for Winnigstadt never fails to make a head. Postpaid, pkt., 10c; 1 oz., $30 \mathrm{c}$; $1 / 1$ lb., $90 \mathrm{c}$; 1 lb., \$2.50.
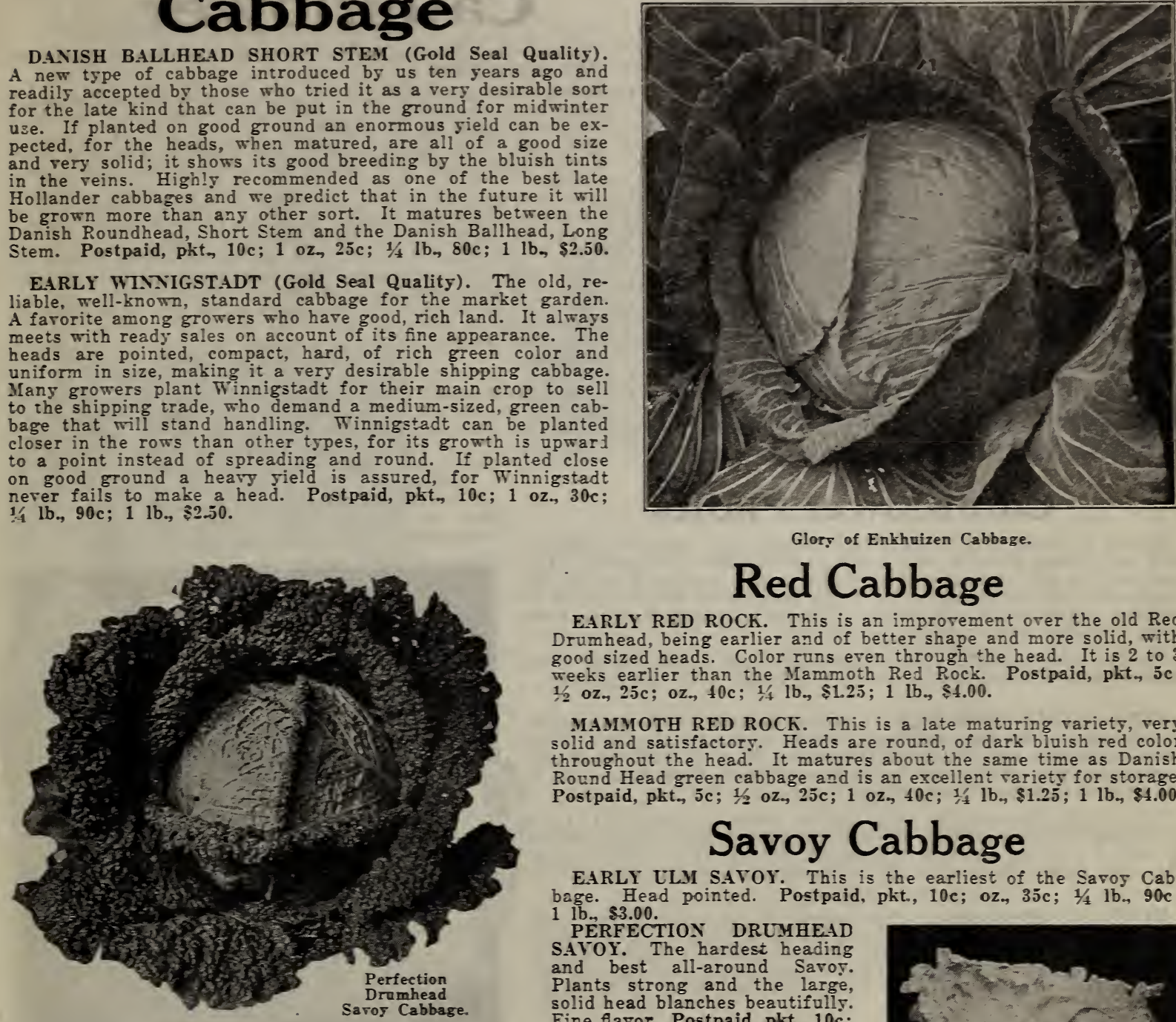

Glory of Erkhuizen Cabbage.

\section{Red Cabbage}

EARLY RED ROCK. This is an improvement orer the old Red Drumhead, being earlier and of better shape and more solid, with good sized heads. Color runs even through the head. It is 2 to 3 weeks earlier than the Mammoth Red Rock. Postpaid, pht, 5c; $1 / 2$ oz., 25c; oz., 40c; $1 / 4$ lb., $\$ 1.25 ; 1$ lb., $\$ 4.00$.

MAMMOTH RED ROCK. This is a late maturing variety, very solid and satisfactory. Heads are round, of dark bluish red color throughout the head. It matures about the same time as Danish Round Head green cabbage and is an excellent rariety for storage. Postpaid, pkt., 5c; 1/2 oz., 25c; 1 oz., 40c; $1 / 4$ lb., \$1.25; 1 lb., \$4.00.

\section{Savoy Cabbage}

EARLY ULY SAVOY. This is the earliest of the Saroy Cabbage. Head pointed. Postpaid, pkt., 10c; oz., 35c; 1/4 1b., 90c; $1 \mathrm{lb} . \$ 3.00$.

PERFECTION DRUMHEAD SAYOY. The hardest heading and best all-around Savor. Plants strong and the large, solid head blanches beautifully. Fine flavor. Postpaid, pkt., $10 \mathrm{c}$ 1 oz., $35 \mathrm{c} ; 1 / 4 \mathrm{lb}, 90 \mathrm{c} ; 1 \mathrm{~b}$, , $\$ 3.00$.

\section{Chinese Cabbage, Pe-Tsai}

A new regetable that is becoming very popular wherever tried. Market gardeners who have planted it have found ready sales and are now growing and cultirating larger patches of Chinese Cabbage each year. This new vegetable is of the cabbage type and the seed can be planted in the open and thinned out leaving the plants 15 to 18 inches apart. When nearly full grown the outer leaves should be gathered about the head and tied at the top; in the same manner as you would tie cauliflower. This allows the head to bleach and become tender. When preparing for the table it should be boiled the same as cabbage or used as cold slaw. Postpaid, pkt., 10c; 1 oz., 35c; 1/4 1b., \$1.00; $1 \mathrm{lb}, \$ 3.50$.

\section{Cabbage and Cabbage Seed}

Cabbage is one of our specialties. We are the largest shippers of Cabbage in Colorado, also the largest dealers in Cabbage seed, so of course, we are anxious that you produce a good crop. We agree to supply the quality of seed that will produce such a crop. To realize the best prices from sour Cabbage crop, keep the plants free from lice and worms; use same insecticides for Cabbage as for cauliflower. See bottom page.

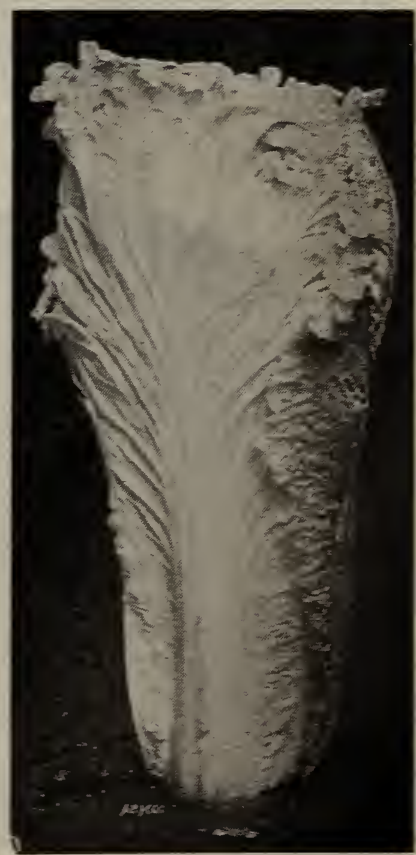

Chinese Cabbage, Pe-Tsai. 


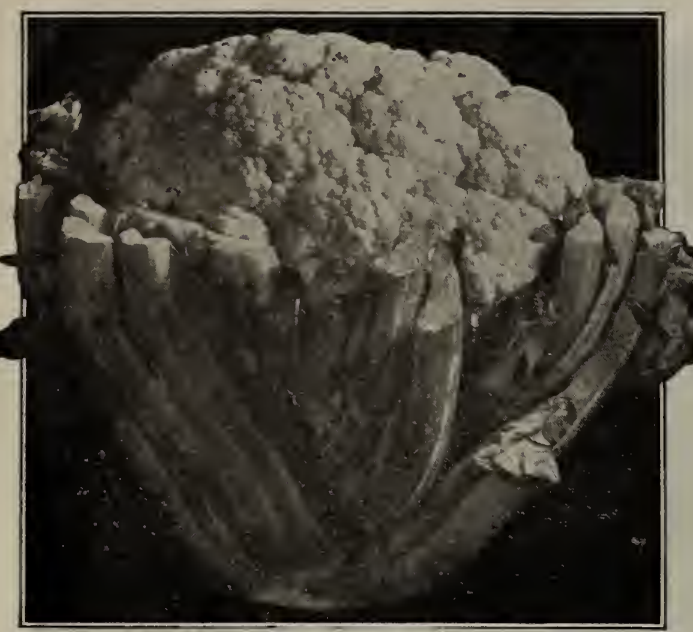

Mountain Snowball.

\section{Cauliflower Plants}

While we grow cauliflower plants to sell, yet, we advise anyone who anticipates growing cauliflower to raise their own plants. Experience has proven that plants started in the locality in which the caulifiower is to be grown do far better than plants shipped in. It is cheaper to grow your own plants. It is not necessary that you have glass. Muslin covers are just as good.

We are large handlers of cauliflower and would like to hear from growers who are anticipating putting in crops in the mountains.

EXTRA EARLY SNOWBALL (Gold Seal Quality). It is the earliest cauliflower and the one cauliflower that is absolutely certain to head when conditions are ordinarily favorable. It is of very dwarf and compact growth, with large, beautiful and snow-white heads. It is five days earlier than Extra Early Erfurt.

This variety is especially recommended where it is desired to grow for the early market when prices are high. Our supply of this variety is limited and we recommend growers placing their orders early. Pkt., 25c; 1/4 oz., 75c; oz., $\$ 2.25 ; 1 / 1$ lb., $\$ 7.00 ; 1$ lb., $\$ 28.00$.

MOUNTAIN SNOWBALL. This variety is one of the leading sorts for mountain main crop. The heads are pure white, compact, thick, and heavy; foliage is dark green, heavily ribbed. A most desirable sort for shipping as a field of this is very uniform in size and the flower is slow to rice. Pkt., $25 \mathrm{c} ; 1 / 2 \mathrm{oz} ., 75 \mathrm{c} ; 1 \mathrm{oz} ., \$ 2.50 ; 1 / 4 \mathrm{lb}$., $\$ 9.00$; 1 lb., $\$ 28.00$.

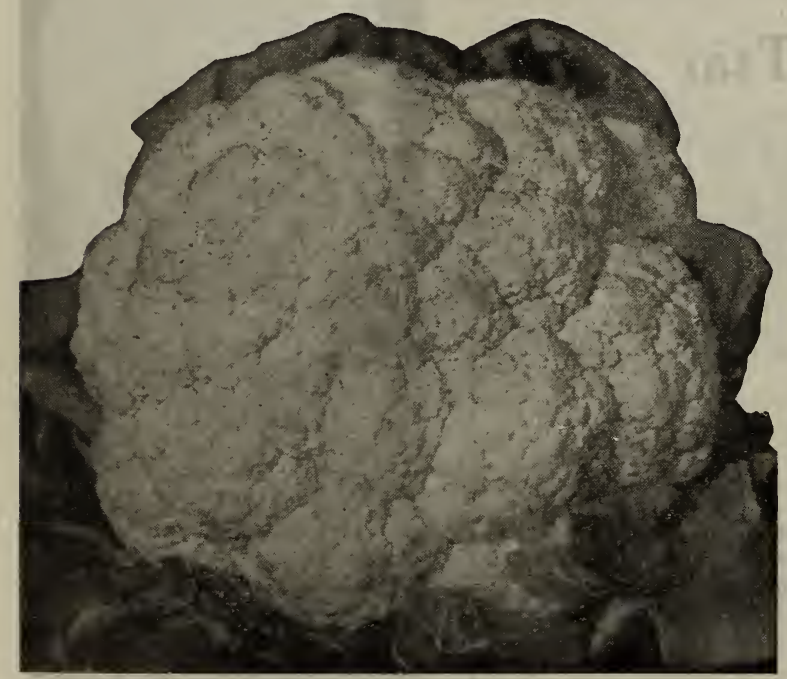

Extra Early Snowball.

\section{Cauliflower}

We are the largest dealers in Cauliflower Seed in the West. Prices

CULTURE. For early crops, sow seed in hotbeds during February. 作

For midseason crops, plant seed in cold frames. For late crops and tied at the ends, thus preventing the light getting

Caution! The roots of cauliflower must at no time be allowed to dry either in the plant bed or in the field as it causes the

INSECTS AND WORMS. Don't fail to destroy the worms and bugs hat appear on cauliflower. This is very easily done by dusting the Shot, or better, a mixture of 50 lbs. Dehydrated Lime, 1 Pint of Nicotine Sulphate and $1 / 2$ lb. Paris Green, thoroughly mixed and dried.

Cauliflower, like Lettuce and Peas, is being grown to perfection in our mountains, for it does best in a rather cool climate, and each year an increasing number of cars will be shipped.

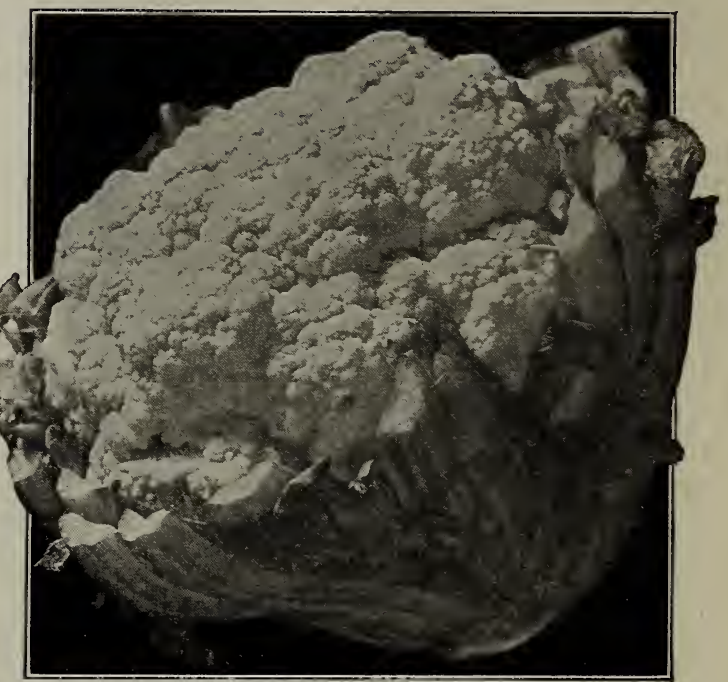

Maxine Snowball Cauliflower.

MAXINE SNOWBALL Or SELF-PROTECTING SNOWBALL. This strain of cauliflower was so highly recommended to us by the largest cauliflower seed growers of Europe that we secured samples and tested it out. To our surprise we found it to be one of the best grades of cauliflower ever grown in our vicinity. It is early and a heavy yielder of even-sized and very firm heads. The foliage is very dense and overlaps the tender flower, thus protecting it from the hot sun and making it an almost sure crop. This strain we highly recommend to growers of cauliflower. It is a sure cropper. Pkt., $25 \mathrm{c} ; 1 / 4 \mathrm{oz}$, 90c; oz., $\$ 2.50 ; 1 / 4 \mathrm{lb}$., $\$ 9.00 ; 1 \mathrm{lb}$, $\$ 30.00$, postpaid.

JOHNSTON'S SPECIAL STRAIN OF SNOWBALL. We have placed this strain of cauliflower in competition with the finest and highest-priced seed sold by all the best dealers in this country and Europe, and have found nothing to equal it in certainty of crop and perfect white heads. It has won the approval of the critical gardeners, being the most reliable sort grown. It is not only suitable for early use, but it is superfine for late planting. The heads are hard and solid and do not spread as do some of the inferior sorts. No other equals it in purity of color, being clear snow-white. Pkt., 25c; 1/4 oz., 90c; 1 oz, $\$ 2.50 ; 1 / 4$ lb., $\$ 9.00$; $1 \mathrm{lb}$. , \$30.00, postpaid. 


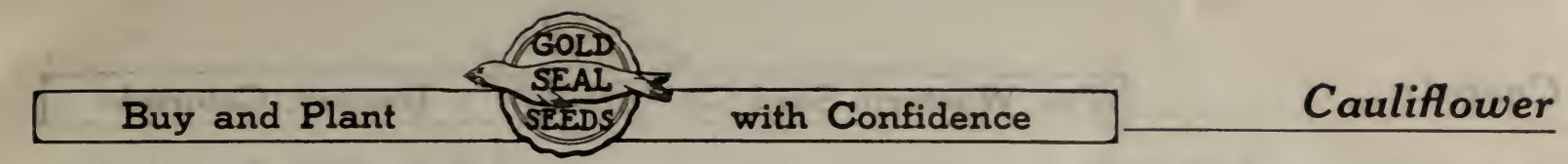

\section{Cauliflower}

DANISH PERFECTION (Gold Seal Quality). Is a very fine and improved variety of the Dwarf Erfurt type. While this cauliflower has only been on the market a short while, yet, year in and year out for midseason crop we recommend it as the most profitable and satisfactory cauliflower to plant, because it is surer to head in hot weather: produces a compact white head of very attractive appearance which is well protected with large, erect outside leaves. It is very uniform in maturing and to use the words of the originator, the entire crop can be harvested at one time for cutting. This variety is especially recommended for dry season. Pkt., 25c; 1/4 oz., 70c; 1 oz, $\$ 2.00$. $1 / 4$ lb., $\$ 7.50 ; 1$ lb., $\$ 27.00$, postpaid.

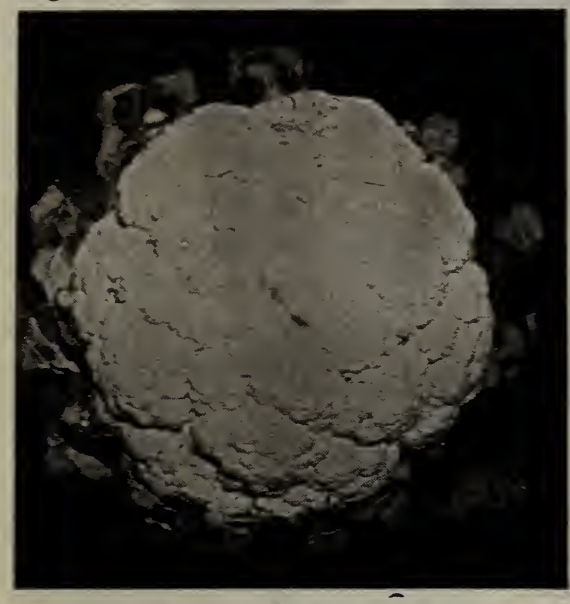

Henderson's Special Strain Snowball.

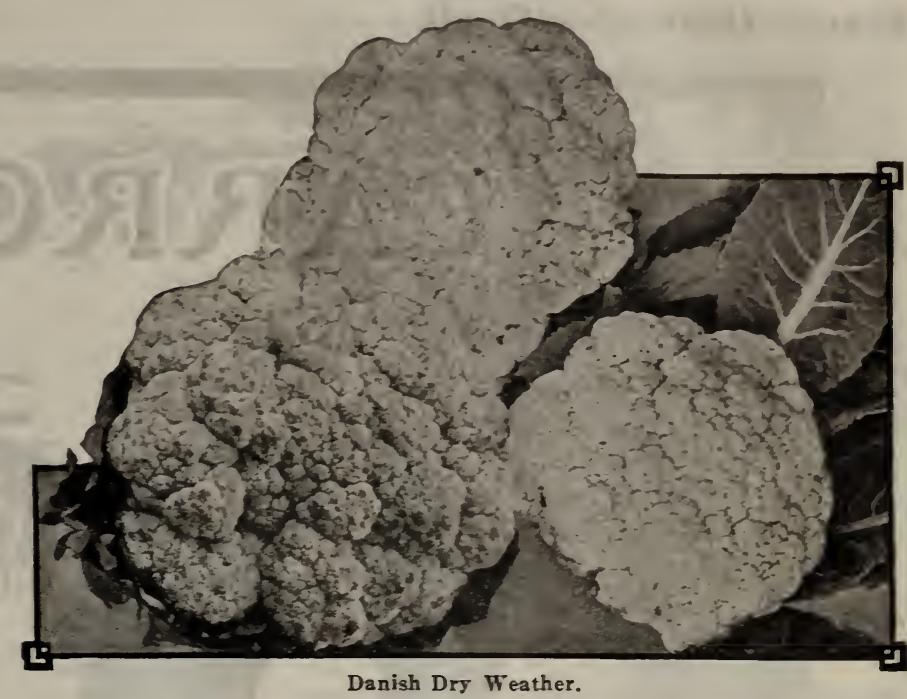

SILVER SPRAY. Early. Is a new introduction. After thorough trials we are satisfied it is superior to any other early Cauliflower and especially adapted to heary soils. Pkt., $25 \mathrm{c} ; 1 / 4$ oz., $75 \mathrm{c} ; 1 \mathrm{oz}, \$ 2.50 ; 1 / 4 \mathrm{lb}$, $\$ 9.00$; $1 \mathrm{lb}$, $\$ 30.00$.

EARLY DWARF ERFURT. For the very early market we recommend this variety; it grows on a short stem; produces solid white heads. As you will note the price of this Cauliflower is very reasonable and planters should not hesitate in using this variety because of this reason. Especially recommended for mountain growing. Price, postpaid: Pkt., 15c; $1 / 4$ oz., 65c; 1 oz., \$1.75; 1/4 lb., \$6.50; 1 lb., \$22.50.

DANISH DRY WEATHER. A very large second early variety, producing immense compact heads, with remarkable heat-resisting qualities. Does well when grown for a fall crop. Prices, pkt., 25c; $1 / 40 z$., $75 \mathrm{c} ; 1$ oz., $\$ 2.00$; $1 / 4 \mathrm{lb}$., $\$ 7.50 ; 1 \mathrm{lb}$, $\$ 25.00$, postpaid.

EARLY PARIS. A hardy variety quite easy to grow and forming good heads. Pkt., 10c; $1 / 4$ oz., $35 \mathrm{c}$; oz., $90 \mathrm{c}$, postpaid.

Cauliflower, like Cabbage, is one of our specialties. It is the fourth largest crop produced in Colorado and with good seed and a reasonable amount of care, Colorado and New Mexico growers are providing the very best quality of Cauliflower. But like Cabbage, Cauliflower must be kept free from worms and aphis. This is easily done if you apply poison early. Do not wait until the plants are covered with lice or eaten up by worms.

The following is a very effective and cheap poison:

\section{0 lbs. Dehydrated Lime \\ $1 / 2 \mathrm{lb}$. Paris Green \\ I Pint of Nicotine Sulphate}

Mix thoroughly. Dust over plants with one of our dusters, (Pages 92-93) or a can with small holes in the bottom will often answer the purpose. The ingredients can be obtained from us ready for mixing.

\section{Amount of Vegetable Seeds Sown to the Acre.}

Artichoke, Jerusalem. Roots Artichoke. 1 oz to 400 plants Asparagus. $1 \mathrm{oz}$, to $40 \mathrm{ft}$. of drili Beans, Dwarf. $1 \mathrm{lb}$. to $100 \mathrm{ft}$. of dril Beets, Table. 1 oz. to $50 \mathrm{ft}$ of drill Beets, for Sugar. $10 z$ to $50 \mathrm{ft}$ of drill Beets, Mangel. $10 z$ to $50 \mathrm{ft}$. of dril Brussel Sprouts. $1 \mathrm{oz}$ to 3000 plants. abbage 1 oz. to 2000 plants Carrot. 1 oz to $160 \mathrm{ft}$. of drili Cauliflower. $1 \mathrm{oz}$. to 2000 plants Celery. $1 \mathrm{oz}$. to 3000 plants Chicors. $1 / 2$ oz to $130 \mathrm{ft}$. of $\mathrm{drili}$ Corn. 1 1b. to 100 hills Cow Peas. Broadcas Cress. $1 / 4$ oz. to $100 \mathrm{ft}$ of drill Cucumbers, 1 oz. to 75 hills Dill. 1/2 oz. to $100 \mathrm{ft}$. of drill Eggolant. 1 oz to 1500 plants Endive. $1 \mathrm{oz}$ to $100 \mathrm{ft}$. of drill Kale. $1 \mathrm{oz}$ to 3000 plants $\ldots . . . . . . . . .$.

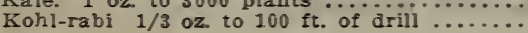

Quantity Per Acrell

400 to $500 \mathrm{lbs}$

40 to $60 \mathrm{lbs}$.

12 to 20 lbs.

$1 / 4$ to $1 / 3$ lb.

$1 / 41 \mathrm{~b}$.

120 to 150 lbs.

$21 \mathrm{bs}$.

3 to $5 \mathrm{lbs}$

1/4 lb. Squash. Summer. 4 ozs. to $100 \mathrm{hilis}$

$41 / 4$ ibs. Squash, Winter. 8 ozs. to 100 hills

$4 \frac{1}{1 / 2}$ lbs. Tobacco. $1 \mathrm{oz}$ to 4000 plants 4 lbs. $1 / 4$ Turnip. $1 \mathrm{oz}$. to $150 \mathrm{ft}$. of drill

Leek. $1 / 3 \mathrm{oz}$ to $100 \mathrm{ft}$. of drill Melon, $10 \mathrm{oz}$ to $100 \mathrm{ft}$. of dr Velon, Water. 4 ozs, to 100 hills asturtiums. $20 \mathrm{oss}$. to $10 \mathrm{ft}$ of drill $1 \mathrm{oz}$. to $100 \mathrm{ft}$. of drill

arsnips. $1 \mathrm{oz}$ to $200 \mathrm{ft}$ of dril arsley. $1 \mathrm{oz}$ to $100 \mathrm{ft}$. of dril oz to 1500 plants eas, Field. In drills ozs, to 100 hiil Padish. $1 \mathrm{oz}$ to $100 \mathrm{ft}$. of drill
Quantity Per Acre

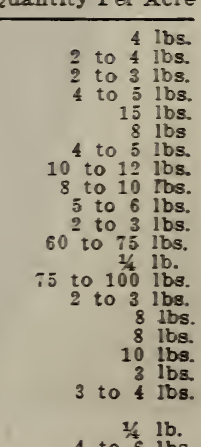

4 to 6 lbs. 


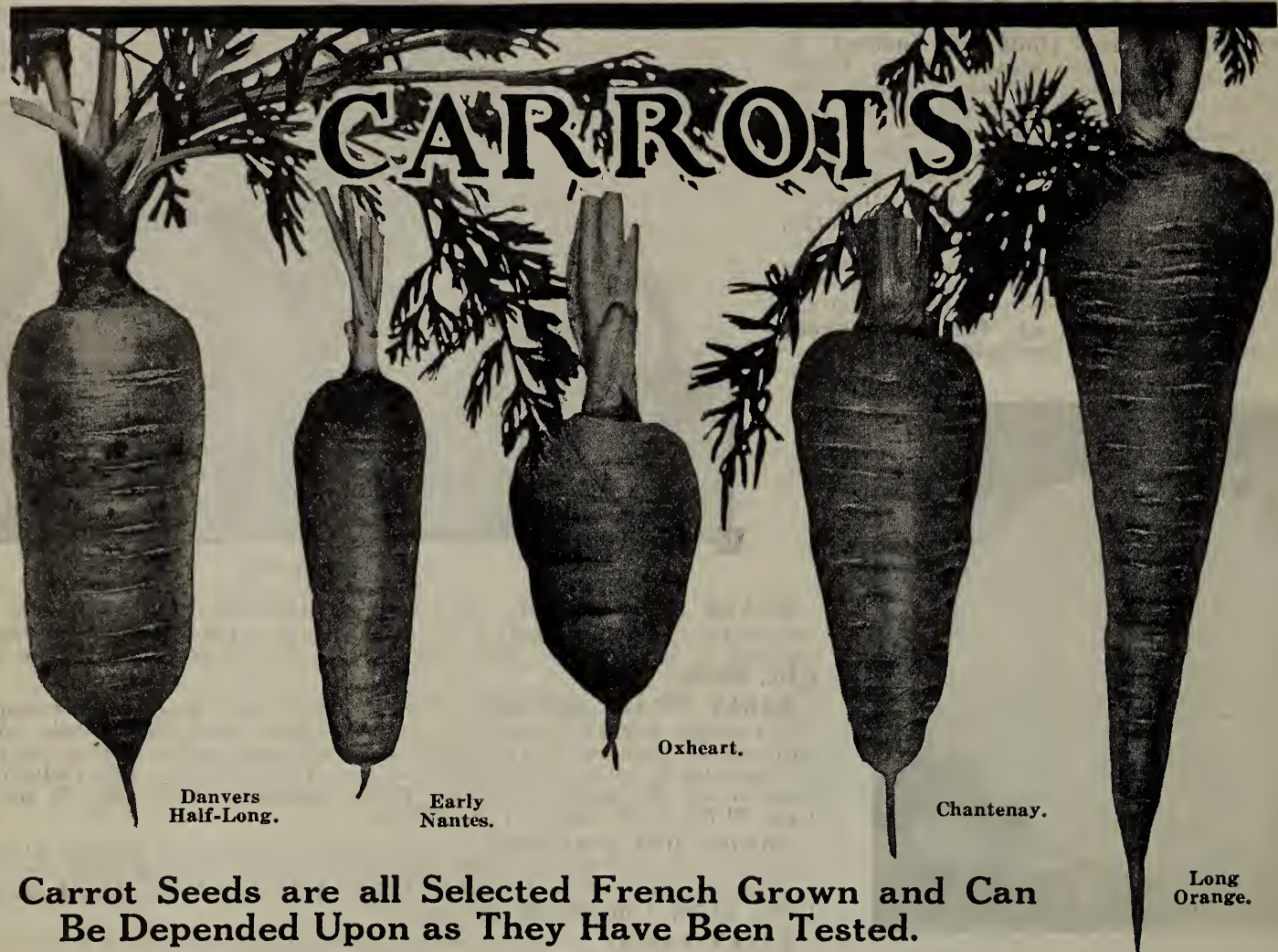

CULTURE. The Carrot will do well in any good, well worked soil. For early use sow the seed when the ground is fit to work, in rows 15 inches apart, and when 2 inches high, thin out so that the plants stand 2 inches apart in the row. For fall and winter use, sow the seed from the 1st to the 15 th of June. The roots may be stored in cellar or pit, covered

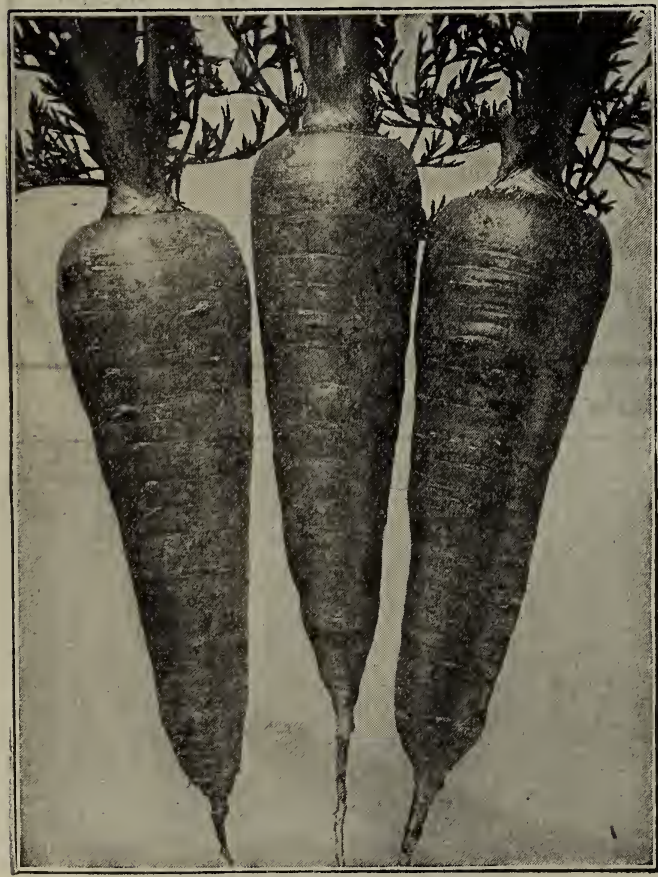

Early Half-Long Nantes. with dirt, where they will keep solid until late in the Spring.

CHANTENAY (Gold Seal Quality). We consider this the standard Carrot, for when young it is about equal to the Nantes for bunching, and later when they increase in size are the best for sacking or for washing and to be sold in bushels. The Carrots grow about 6 inches long, fine grained, sweet, and sugary. It is not as long as the HalfLong Danvers, and is more stump rooted and not apt to crack open while growing. An excellent table variety and heavy cropper. Our seed is most carefully selected. Pkt., 5c; oz., 15c; 1/4 lb., 35c; 1 lb., $\$ 1.00$, postpaid.

DANVERS HALF-IONG (Gold Seal Quality). The most popular variety with nine-tenths of the market gardeners in this vicinity, It will produce more than any other kind, and cannot be equalled as an all around Carrot. Very suitable for bunching for summer sales, and on the other hand, being an excellent keeper, it may be stored in pits, when the tops are cut, and sold during the Winter. It is rich orange in color and a bumper cropper-much favored for stock feeding. Grows 5 to 7 inches long, 2 to $2 \frac{1}{2}$ inches wide at the top. Pkt., 5c; oz., 15c; $1 / 4 \mathrm{lb}$., 35c; $1 \mathrm{lb}$., $\$ 1.00$, postpaid.

EARLY HALF-LONG NANTES (Gold Seal Quality). This variety is the earliest of the standard sorts and on account of its fine bright color is planted very extensively in this section for a bunching carrot, presenting a very fine appearance when bunched. It is sweet and fine flavored, almost without a core, very fine grained. Excellent for home garden, as well as for the market. One of the finest in quality and handsomest in shape of the medium sized sorts. Pkt., 5c; $15 \mathrm{c} ; 1 / 4 \mathrm{lb} ., 35 \mathrm{c} ; 1 \mathrm{lb} ., \$ 1.00$, postpaid.

FEONIA. A carrot of great promise, its bright orange-scarlet color, its splendid size, shape, and productiveness all being very much in its favor. Although a cross between the Nantes and Chantenay, it resembles the Hutchinson more than any other, but the top is not quite so green. We feel that it will quickly take a leading place among the sorts grown for bushel sales. Try it in your garden this year. You will be pleased with its good qualities. Pkt., 10c; 1/2 oz., $15 c ; 0 z ., 20 c ; 1 / 4$ lb., 65c; lb., $\$ 2.25$, postpaid. 


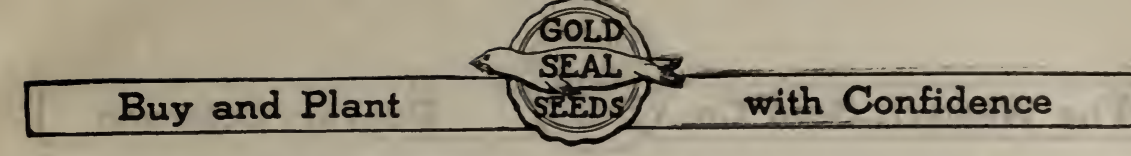

Carrots

\section{CARROTS-Continued}

EXTRA EARLY SCARLET HORN. This variety should not be planted for the main crop. Its growing should be confined to the extra early marketing when as yet there are none of the standard varieties offered. Pkt., 5c; 0z, 15c; $1 / 4 \mathrm{lb}$., 35c; 1 lb., $\$ 1.00$, postpaid.

OXHEART or GUERANDE. The most popular and heaviest cropper among the short carrots. The shape is very desirable for heavy soils. The true type is about $4 \frac{1}{2}$ inches long and 3 inches thick at the shoulder, tapering slightly to the bottom, and is very stump rooted. Pkt., 5c; oz., 10c; $1 / 4$ lb, 30c; $1 \mathrm{lb}$, $\$ 1.00$, postpaid.

FRENCH CORELESS. This is a half-long, cylindrical carrot, blunt pointed with small tap-root and small top. They run uniform in size and shape, 6 to 7 inches long by $1 \frac{11}{2}$ inches through, clear skinned, easily pulled, and keep well. The flesh is fine in texture, sweet and mild flavored, entirely devoid of stringiness, coarseness or wood-heart or core. Color of flesh is rich red-orange. Excels other half-long carrots in earliness without being inferior in productiveness. Pkt., $5 \mathrm{c} ; 0 \mathrm{z} ., 15 \mathrm{c} ; 1 / 4 \mathrm{lb}$, $40 \mathrm{c}$; $1 \mathrm{lb}$, $\$ 1.15$, postpaid.

\section{CARROTS FOR STOCK FEEDING}

Attention-Don't Fail to Plant at Least a Few Carrots for Your Stock

Carrots make a healthy and desirable food for horses, and every horse owner should plant them liberally, so as to give his horses an occasional feed of carrots through the winter. They are also very desirable for feeding to hogs and cattle and make a tonic and alterative food which is of decided benefit. Plant in March, April or May-the earlier the better-at the rate of 3 to 4 pounds per acre. Cultivate same as mangel beets.

MASTODON CARROT. This abundant yielder is strictly a stock carrot and grows to be of enormous size. Now, if you want a good winter feed for your stock don't overlook this new wonder, for it is just what your horses and other stock need. There is no use to tell you what carrots do for stock, for everybody knows that a horse or a cow likes carrots. But, speaking of carrots, this extra large, massive, heavy producer is what you want to plant for a stock carrot. Plant 2 pounds to the acre of this seed. Pkt., 5c; Oz., 10c; 1/4 lb., 25c; 1 lb., 90c, postpaid.

IMPROVED LONG ORANGE. This variety should not be planted for market use, although it has a good color and the same flavor as the Danvers, but owing to its long, tapering growth it does not sell well for table use. It is grown extensively for stock feeding. Pkt. 5c; oz, $10 \mathrm{c} ; 1 / 4 \mathrm{lb}$., $25 \mathrm{c}$; $1 \mathrm{lb}$., $75 c$, postpaid.

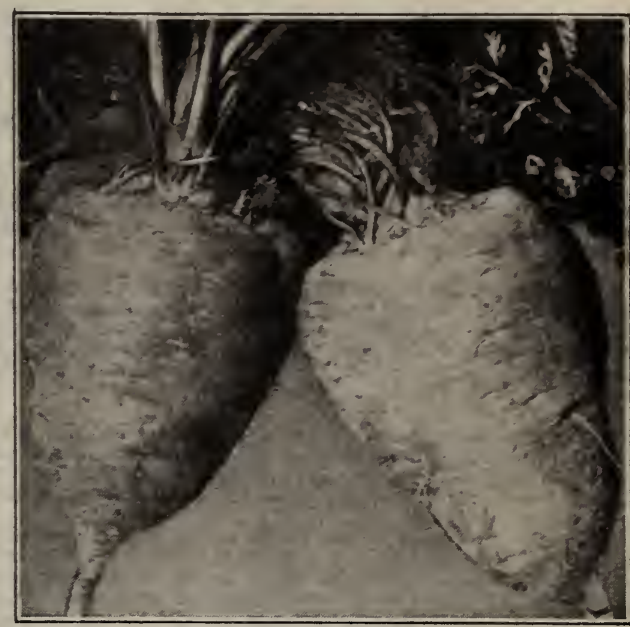

Oxheart Carrots.

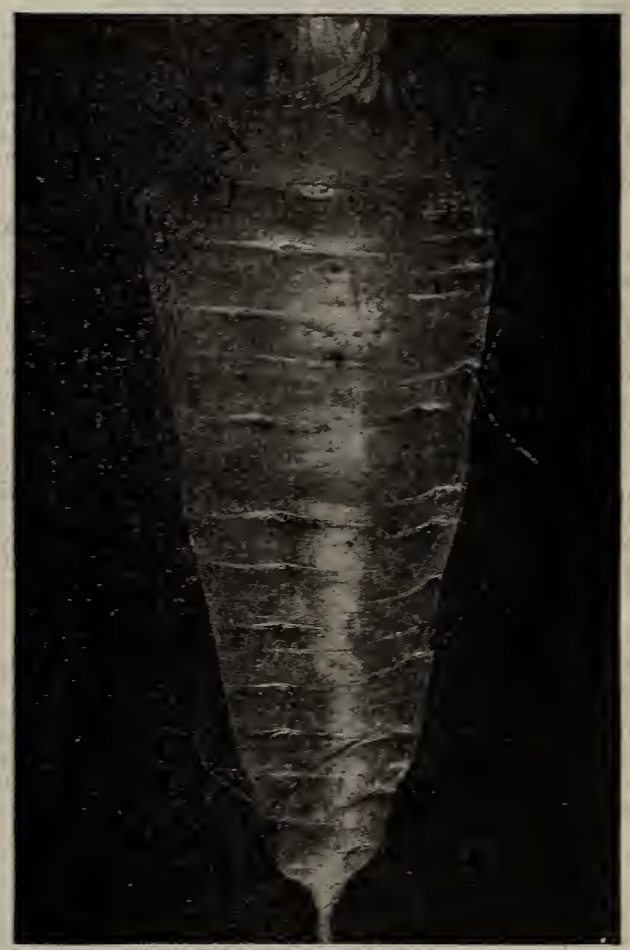

Chantenay Carrot.

GLANT WHITE BELGLAN. Roots grow one-third above ground, are white below and green above ground; small tops; flesh somewhat coarse, roots large size, and are extensively grown for stock feeding. Pkt., 5c; oz., 10c; $1 / 4 \mathrm{lb}$., 25c; $1 \mathrm{lb}$., $75 \mathrm{c}$, postpaid.

GIANT YELLOW BELGIAN. They do not produce as large roots as the White Belgian; the flesh is less coarse. It grows about 11 inches in length and 3 to $31 / 2$ inches in diameter at the crown. Gives a large yield and is very easy to harvest. Pkt., 5c; oz., 10c; 1/4 lb, 25c; 1 lb, $75 \mathrm{c}$, postpaid.

\begin{tabular}{|c|c|c|}
\hline \multicolumn{3}{|c|}{$\begin{array}{l}\text { SOUP COLLECTION } \\
\text { SPECIAL PRICE, } 25 \text { CENTS, POSTPAID }\end{array}$} \\
\hline $\begin{array}{l}1 \text { Pkt. Carrots } \\
1 \text { Pkt. Celery }\end{array}$ & $\begin{array}{l}1 \text { Pkt. Cabbage } \\
1 \text { Pkt. Parsley } \\
1 \text { Pkt. Peas } \\
\text { Regular Price, 45c }\end{array}$ & $\begin{array}{l}1 \text { Pkt. Turnips } \\
1 \text { Pkt. Onions }\end{array}$ \\
\hline
\end{tabular}




\section{Celery}

\section{Our Celery Seed is Tested and Guaranteed Pure}

Celery is one of the main vegetable crops of Colorado. Next to Cabbage and Lettuce it is the largest crop of vegetables produced in Colorado. While there are many varieties of Celery, only a few sorts prove profitable, namely: Hartner's Early' Wonder, Golden Self-Blanching, Giant Pascal, Golden Summer and Hartner's Country Club.

CULTURE FOR SUMMER CELERY. Seed is started in hotbeds the middle of March and requires close attention, keeping the seed bed moist and giving plenty of air. Plants should be set out any time between the 1st and 20th of May. Best results are obtained from double rows, that is, set plants on each side of the irrigating ditch. Set plants from 6 to 8 inches apart in the rows, and double rows 3 to $31 / 2$ feet apart.

Self-Blanching Celery requires close attention and plenty of cultivation, as it is very injurious to the crop if the plants are allowed to stunt, which is caused from lack of cultivation and improper irrigation. Celery requires plenty of water, but water should not be allowed to stand in the rows.

After the Celery is about ready to harvest it can either be bleached with paper, boards or by banking with dirt. The former method is used when early Celery is desired. Bleaching with boards is quite expensive and growers of large fields usually bleach with paper or with dirt. Very often the summe varieties after they are fully matured will bleach without boards or banking.

If grower desires to keep Celery later than October 20th, it should be confined to trenches for protection aginst the cold.

CULTURE FOR WINTER CELERY. Seed should be sown as late as April 15 th and planting outdoors can be done any time from June 1st to July 25 th This variety of Celery requires artificial bleaching, either by wrapping each stalk separate with paper or by trenching. The former method is only used when early pascal Celery is desired, but for flavor, quality, and long keeping, when early pascal Celery is desired, but for flavor, quality, and long keeping,
trenching is necessary. After the stalks have been stored in trenches some time, the hearts make considerable growth and it is this heart which was produced in the trench while stored that is so palatable.

NEW GOLDEN SELF-BLANCHING (Gold Seal Quality). Golden Self-Blanching is the most satisfactory Celery to grow for Summer marketing because it is more popular and has a wide market. Many new varieties : of summer Celery have been introduced but they have not proved satisfactory because they are more or less of the green variety, but this wonderful new variety of Celery is sure to become a favorite with those who grow for the Summer and Fall market. It retains all the characteristics of the old Golden Self-Blanching but is stronger, more vigorous, grows about one-quarter larger and is a quicker grower, but does not hold up as well. After being cut it is very quick to wilt nor is the heart growth as heavy as the old variety. In planting, one should give this variety more space so it may properly develop. Pkt., 15c; $1 / 2$ oz., $75 \mathrm{c} ; 1$ oz., $\$ 1.25$; $1 / 4 \mathrm{lb}$., $\$ 4.00 ; 1 \mathrm{lb}$., $\$ 12.00$.

HARTNER'S GLANT PASCAL. This Pascal is an improved and highly developed strain of Giant Pascal. It is much larger than the regular Pascal and free from sof stalks. The seed is grown in Colorado. Its appearance and form are perfect, and its eating qualities are better than any celery ever offered for the table. It is free from strings, crisp, and sweet, and does not get soft. For the market gardener and winter Celery growers there is none better.

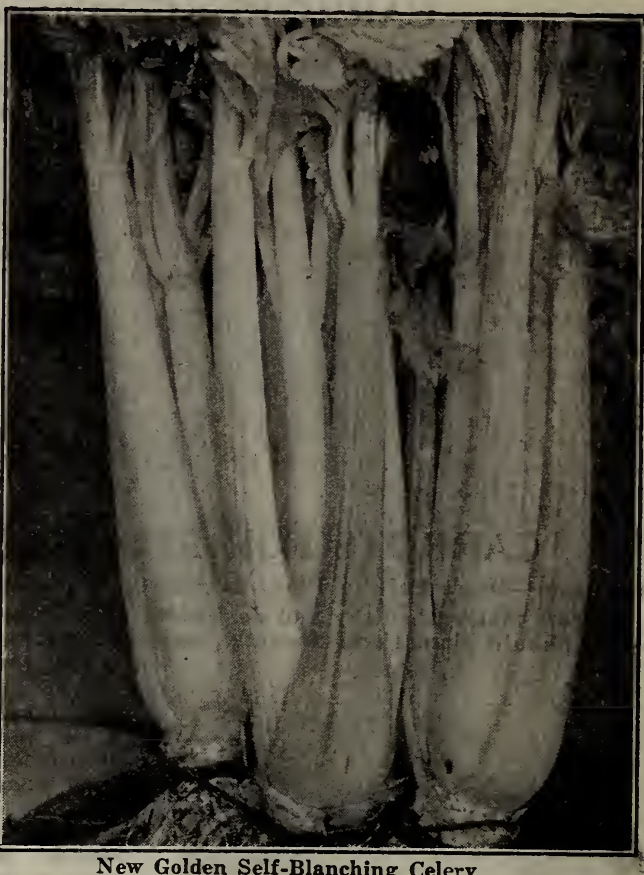

Its earliness and size make it the most profitable of al Celery. By early, we mean that it grows to an enormous size and grows quick so that it can be wrapped in paper and bleached above ground weeks before frost. It paper harvested from the field at the high prices that prevail for early Pascal Celery. Thousands of dozens of Celery are sold this way and the grower does away with trenching. or else, it can be allowed to grow still larger and just before cold weather can be stored for the Winter in trenches, keeping perfectly until Spring. When taken out it will be bleached and possesses the rich, nutty flavor that is making it the favorite Pascal. Pkt., 25c; 1/2 oz., 50c; oz., 75c; $1 / 4$ lb., $\$ 2.00$; lb., $\$ 6.00$, postpaid.

GOLDEN SELF-BLANCHING (Old Variety)-(Gold Seal Quality). This is the regular Golden Self-Blanching, that has been grown with success for many years from California to New York, from Washington to Florida. While the new variety of Golden Self-Blanching will, no doubt, be planted to a greater extent than ever before, yet we feel that all growers who plant for shipping will do well to plant at least a part of their field to this old variety, because it holds up better after being cut, and for storing we recommend this strain. Pkt., 10c; $1 / 2$ oz., 60c; oz., $\$ 1.00$;
$1 / 4 \mathrm{lb}, \$ 3.00$; lb., $\$ 8.00$.

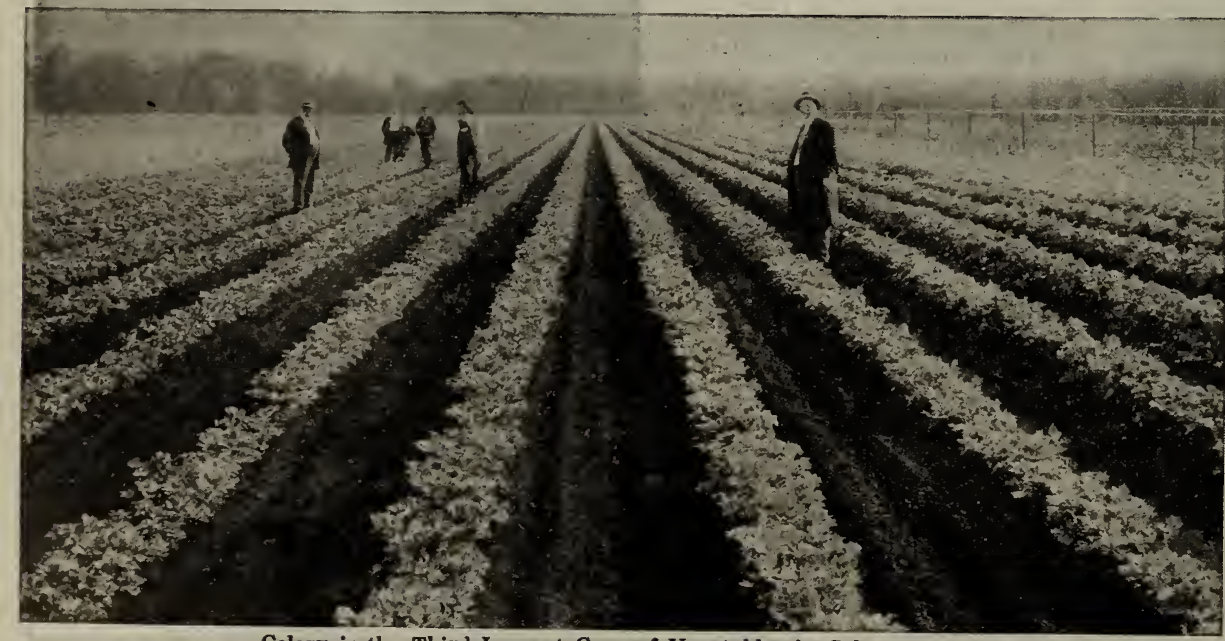

Celery is the Third Largest Crop of Vegetables in Colorado.

\section{CELERY PAPER}

In the large celery growing districts of Florida and California they no longer use boards for bleaching their celery, but a special made paper is used, which is cheaper and more economical than boards, quicker and cheaper to put on, and lasts just as long. Price, roll, 12 inches wide, 310 feet long, $\$ 2.25$ each, not prepaid. 


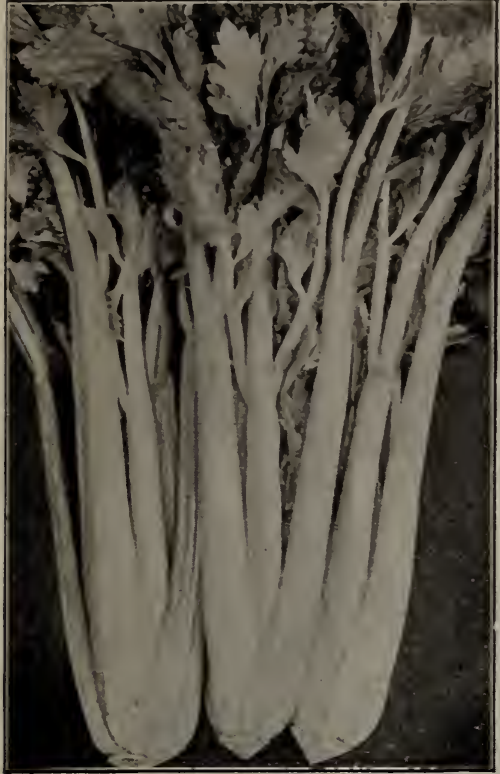

Hartner's Giant Pascal.

\section{CELERY-Continued}

COUNTRY CLUB or SALT LAKE CELERY. Celery grown in the Salt Lake District has built up a wonderful reputation. Many authorities consider it superior to the Pascal. The stems or stalks are thick and meaty, producing very sturdy plants with a large heart, however the outer stalks are just as palatable. From experience we find this celery is not adapted to trenching but should be bleached by wrapping with paper or banking with dirt. Pkt., 25c; oz, $\$ 1.00 ; 1 / 41$ b., $\$ 2.25$; $1 / 2$ lb., $\$ 4.00 ; 1 b ., \$ 8.00$, postpaid.

GOLDEN SUMMER. This is a cross between the Easy Bleaching and Golden Self-Blanching. It has the hearty robust habits of the Easy Bleaching and the color of the Golden Self-Blanching. We believe it will prove very valuable and will eventually take the place of the Golden Self-Blanching, as soon as its qualities are known. Pkt., 20c; $1 / 2$ oz., $\$ 1.00 ; 0 z$, $\$ 1.50 ; 1 b ., \$ 20.00$.

SELECTED WHITE PLUME Almost self-bleaching. Its stalks and portions of the inner leaves and heart are nearly white. Early, of good flavor and fine texture; adapted to fall and early winter use; a good keeper up to the holiday season. Pkt., 10c; $1 / 2 \mathrm{oz} ., 20 \mathrm{c}$; $1 / 4 \mathrm{lb}$., $80 \mathrm{c}$; lb., $\$ 2.50$, postpaid.

GLANT PASCAL (French). By many, Giant Pascal is considered the sweetest and best flavored Celery grown and on account of its fine keeping qualities it is one of the best Winter varieties. The plants are usually started in cold frames and planted in the open during the month of June, and as late as July 10th. To enable the grower to market this variety earlier than November 1st, ordinary newspaper is used to wrap about the stalk while growing in the field, and left so until the stalk, which was originally dark green, becomes whitened. Although Pascal, when treated in this manner, brings a very good price, it does not acquire as sweet a flavor as when trenched. This strain of seed is French-grown and of very good quality; however, planters who grow for the market prefer Hartner's Giant Pascal, which is listed here. Pkt., 10c; oz., 30c; $1 / 4$ lb., $80 \mathrm{c}$; lb., \$2.50, postpaid.

\section{Chicory}

WITLOOF, or FRENCH ENDIVE. Is used principally as a winter salad, and it is most delicious served with French dressing. The seed should be sown in the open ground not later than June, in drills 12 to 18 inches apart and the seedlings should be thinned out to stand not closer than 3 inches. The plants form long, parsnip-shaped roots which are lifted in the Fall, trimmed of leaves and stored in a cool place until wanted for forcing. The roots should be planted upright about $1 \frac{1 / 2}{2}$ to 2 inches apart in a trench 16 to 18 inches deep. The roots when grown as above produce leaves which are delicious as a winter salad. Pkt., 10c; oz, 30c; $1 / 4 \mathrm{lb}, 90 \mathrm{c}$, postpaid.

IMPROVED LARGE LEAVED. As the name indicates, the leaves of this sort are larger than the common kinds. This is a very superior variety. Pkt., 5c; oz., $20 c ; 1 / 4$ lb., 50c; lb., $\$ 1.50$, postpaid.

LARGE ROOTED. The roots are cut in thick slices, roasted and used instead of coffee. Leaves in the Spring are also used for salads. Pkt., 5c; oz., 20c; $1 / 4$ lb., 50c; lb., \$1.50, postpaid.

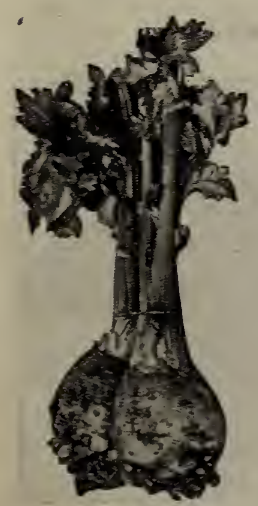

\section{Celeriac or Turnip Rooted Celery}

Grown for the roots, which are large, turnip-shaped; tops very small. Although the consumption is limited, due to the fact that its eating qualities are so little known, for a salad it excels all other varieties of Celery, having a fine flavor. It can also be stewed or used for flavoring. It may be stored like beets and will keep all Winter. Pkt, 5c; oz., 20c; $1 / 4$ lb., 70c; Celeriac.

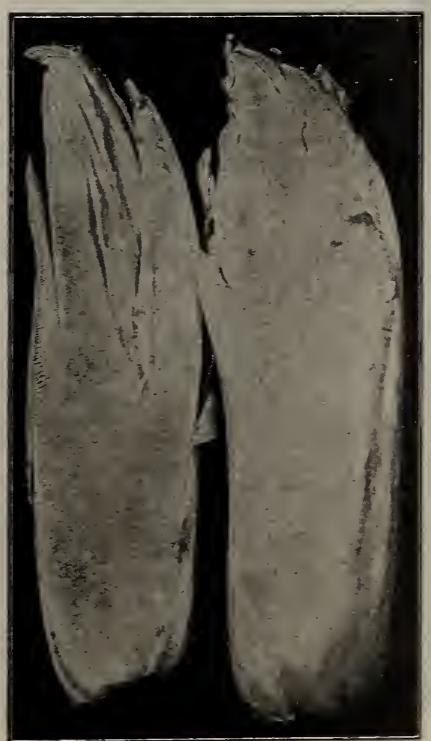

Witloof Chicory.

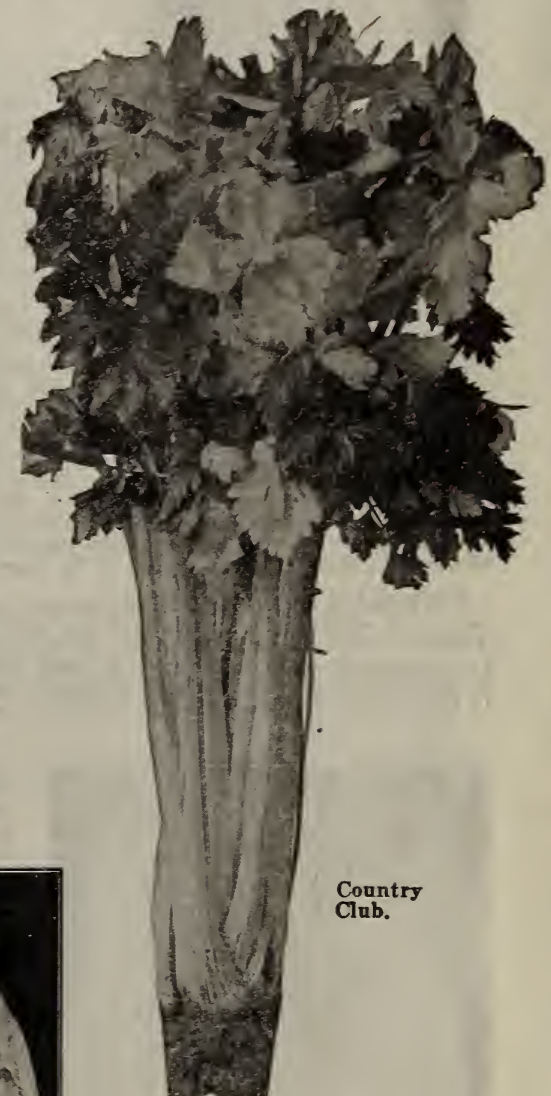

Chervil

A hardy plant which resembles double curled parsley and is used for flavoring and garnishing. Pkt., 5c; oz., 10c; $1 / 4$ lb., 30c; lb., $\$ 1.00$, postpaid.

\section{Chives}

An onion-like plant, used in salads and for flavoring soups. The plant also makes an excellent ornamental garden bed edging, which may frequently be cut, a new growth of leaves appearing soon after each cutting. One sowing will answer for about 3 years. Pkt., 5c; $1 / 4$ oz., 25c; oz., $75 \mathrm{c}$, postpaid. (Chives Plants-See page 42) 


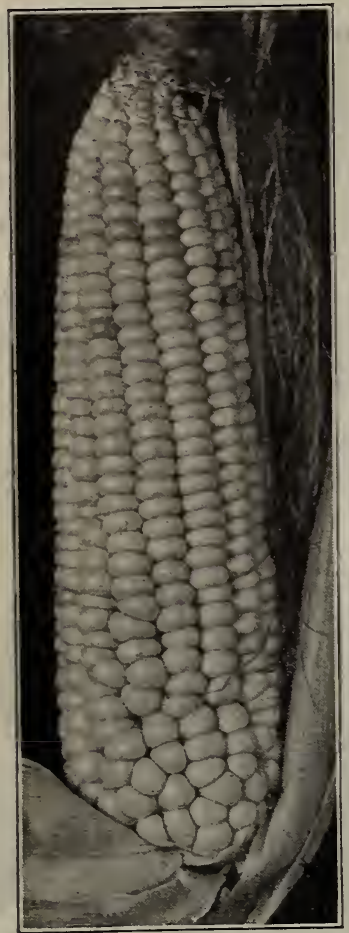

Hartner's Pearl.

\section{Sweet Corn}

Our Prices are Postpaid Up To and Including Ten Pounds You Should Plant Western Grown Seeds

CULTURE. A rich, warm sandy soil is the best, but excellent sweet corn can be raised on any good, ordinary soil if it is deeply and thoroughly worked before planting. In the West sweet corn should be planted as early as can be done without risking great loss from frosts or from rotting of the seed in the soil. If planted in rows, make the rows about 4 feet apart and place the seed 14 to 16 inches apart in the row, covering 1 inch deep with fine soil firmly pressed down. If planted in hills, make the hills for the early varieties 3 feet apart each way and plant 6 kernels to the hill. For the later sorts the hills should be not less than 4 feet apart each way. Hoe frequently, and when 6 inches high thin so as to leave 3 or 4 plants in the hill. Give frequent and thorough but shallow cultivation until the tassels appear.

\section{Hartner's Pearl}

The Earliest Sweet Corn in Cultivation

There is no other vegetable that is awaited with so much eagerness as the first Sweet Corn, but the great disadvantage with our first roasting ears is, they are either of very small size or they are not of a sweet flavor.

HARTNER'S PEARL is an extremely early variety of corn that has been thoroughly acclimated to our climate and will continue to grow throughout the early cold spring days when other varieties usually become stunted. Several experiments on different soils the past season proved the Early Pearl to be from 5 to 10 days earlier than any other variety of early corn. Besides being extremely early it produces good sized ears with 8 to 10 rows of exceptionally fine pearly Sweet Corn. It is superior to all other varieties of early corn for it withstands light frost and can be planted early in the Spring and will, from the day of germination, rush forward to meet the early demand for sweet green corn. It is a fine early corn for the garden and a money maker for the market gardeners. Postpaid, pkt., 5c; 2 oz., 10c; 1b., 30c; 5 lbs., $\$ 1.35 ; 10 \mathrm{lbs}$., $\$ 2.50$. If by freight or express at purchaser's expense, $5 c$ per lb. less.

EARLY GOLDEN BANTAM (Gold Seal Quality). Is the sweetest, richest, and most tender sweet corn grown. One of the finest. The ears are from 6 to 7 inches long, eight rowed, filled with broad, sweet, golden yellow kernels of a delightful flavor. It may be planted from 10 days to 2 weeks earlier than most sweet corns, as it is not as apt to rot as many of the softer kinds. It is as early as the Cory and of much better flavor. It is always good, whether planted in the Spring or during the Summer. We advise all lovers of sweet corn to give "Golden Bantam" a trial. Prepaid, pkt., 5c; large pkt., 10c; $1 / 21 \mathrm{lb}$., 15c; 1 lb., $25 \mathrm{c} ; 5 \mathrm{lbs}$., $\$ 1.00 ; 10 \mathrm{lbs}$., $\$ 1.85$. If by express or freight at purchaser's expense, $5 \mathrm{c}$ per lb. less.

STOWELL'S EVERGREEN (Gold Seal Quality). This is the corn with the long, deep kernels; the kind gou enjoy eating. This variety is the most widely known and best advertised of all late sweet corns, and therefore there is more Stowell's Evergreen planted for late crop than all other late varieties together. The large ears of 18 to 20 rows of long, deep, juicy, tender kernels makes it such a favorite. It produces an abundant amount of fodder. Postpaid, pkt., 5c; large size pkt., 10c; 1/2 lb., 15c; 1 lb., 25c; 5 lbs., $\$ 1.00$ 10 lbs., $\$ 1.85$. If by express or freight at purchaser's expense, $5 \mathrm{c}$ per $1 \mathrm{~b}$. less.

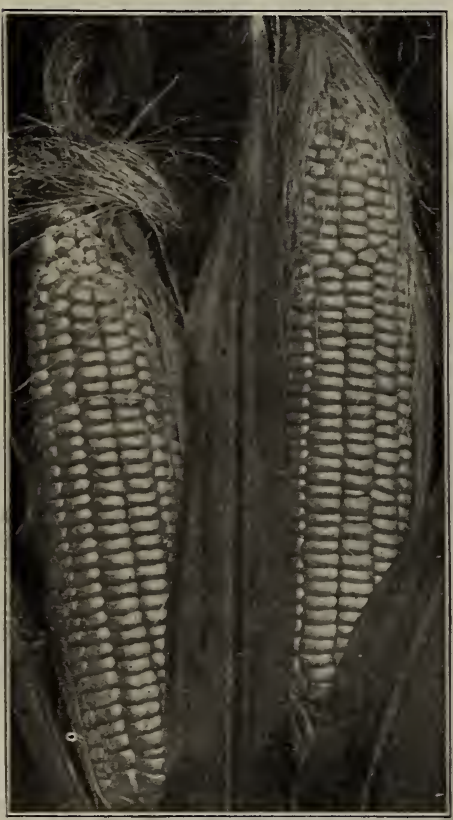

EARLY MAYFLOWER (Gold Seal Quality). In the Mayflower we offer you one of the earliest sweet corns, being ten days earlier than the Early White Cory. The ears are very much Golden Evergreen.
in quality will be found far superior in spite of its extreme earliness. The stalks are six inches to a foot shorter than the Cory.

No one appreciates the above merits in sweet corn more than the market gardener, for he realizes that to obtain the highest prices that are paid for corn he must have it on the market early, and the corn must be of good size and sweet flavor, such as is produced by this wonderful corn. From comparison we note there are offered 2 or 3 different strains of Mayflower corn. And comparing them to our special strain we find that our stock cannot be equaled in earliness, size of ear and productiveness. Don't fail to get our genuine special strain

Prices, pkt., 5c; large pkt., $10 \mathrm{c} ; 1 / \mathrm{lb} ., 15 \mathrm{c} ; 1 \mathrm{lb}$., $25 \mathrm{c} ; 5$ lbs., $\$ 1.15 ; 10$ lbs., $\$ 1.85$, postpaid. If by express or freight at purchaser's expense, $5 c$ per lb. less.

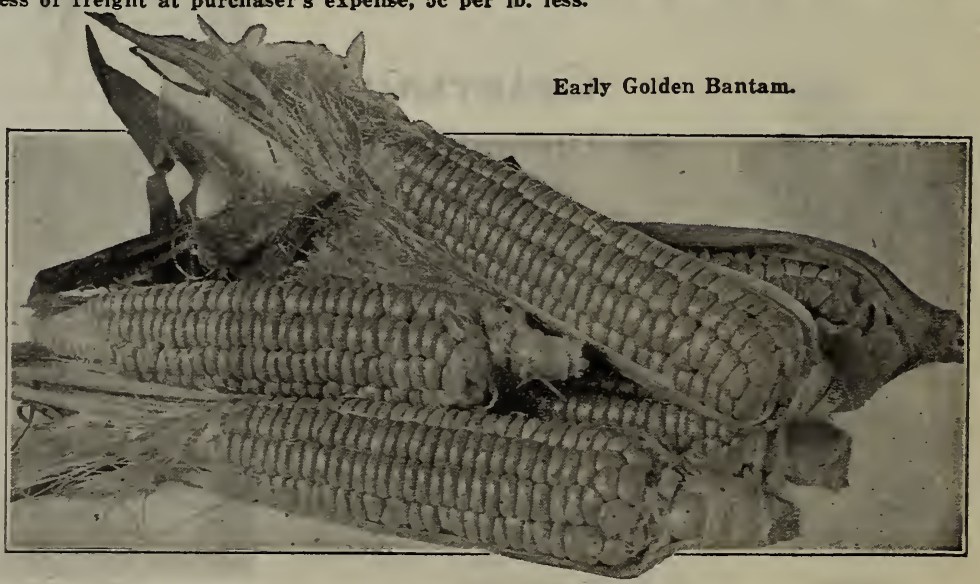




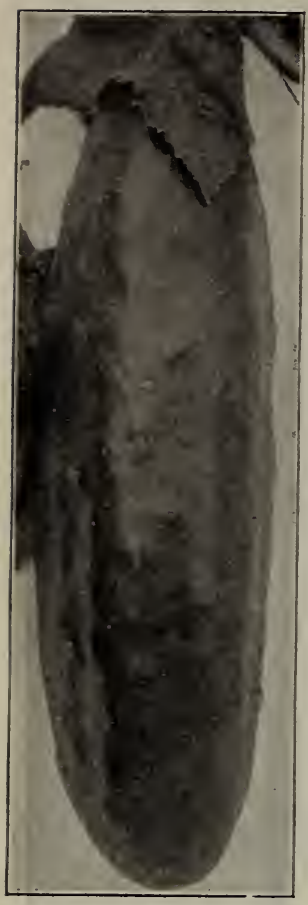

Davis Perfect.

DAVIS PERFECT. This is the popular cucumber so greatly used by all market gardeners, being productive, dark green in color, and grows 8 to 14 inches in length, having few seeds, and remains green a long time. A good keeper. Postpaid, pkt., 5c; oz., 15c; 1/4 lb., 40c; lb., \$1.25. variety for size, color, and keeping qualities. Postpaid, $90 \mathrm{c} ; \mathrm{lb} ., \$ 1.50$.

WESTERN GLASS. This is a cucumber we have recently bred up, especially for hothouse cultivation; altried it use it also for outside planting. It is extra long, 18 to 20 inches. Is unusually dark green, firm, and straight. Pkt., 15c; oz., 35c; $1 / 4$ lb., 90c; $1 / 2$ lb., $\$ 1.75$; lb., $\$ 3.00$.

\section{Cucumbers}

(Prices on Cucumbers Postpaid)

Our Cucumber Seeds are all Colorado grown, and will produce heavy crops-besides being dealers in Seeds, we are Colorado's largest shippers of Vegetables.

CULTURE. As soon as the weather has become settled and warm, plant in hills 4 to 6 feet apart each way, with 8 to 10 seeds in a hill. Cover one-half an inch deep, smoothing the hill off with the hoe. When the plants,are out of danger of insects, thin out to 3 or 4 plants to a hill. Cultivate and hoe often until the plants begin to make runners or vines.

IMPERIAL CUCUMBERS. Another strictly Western Grown "Gold Seal" product that has attained the highest favor among the most critical cucumber growers in the country, and has taken the place of such valuable varieties as the Davis Perfect, Fordhook Famous, Long Green, White Spine, etc., among the market gardeners, because it is more prolific, of better color and more uniform in size, averaging from 10 to 14 inches in length. They are always straight and free from crippled or little necks, withstands blight better and has practically no seed chamber, but it is composed of almost solid white firm flesh that is most delicious in flavor. We especially recommend it to growers for outdoor plant-

ing, as a shipping cucumber. It excels any other pkt., 10c; oz., 15c; $1 / 2$ lb., though many growers who

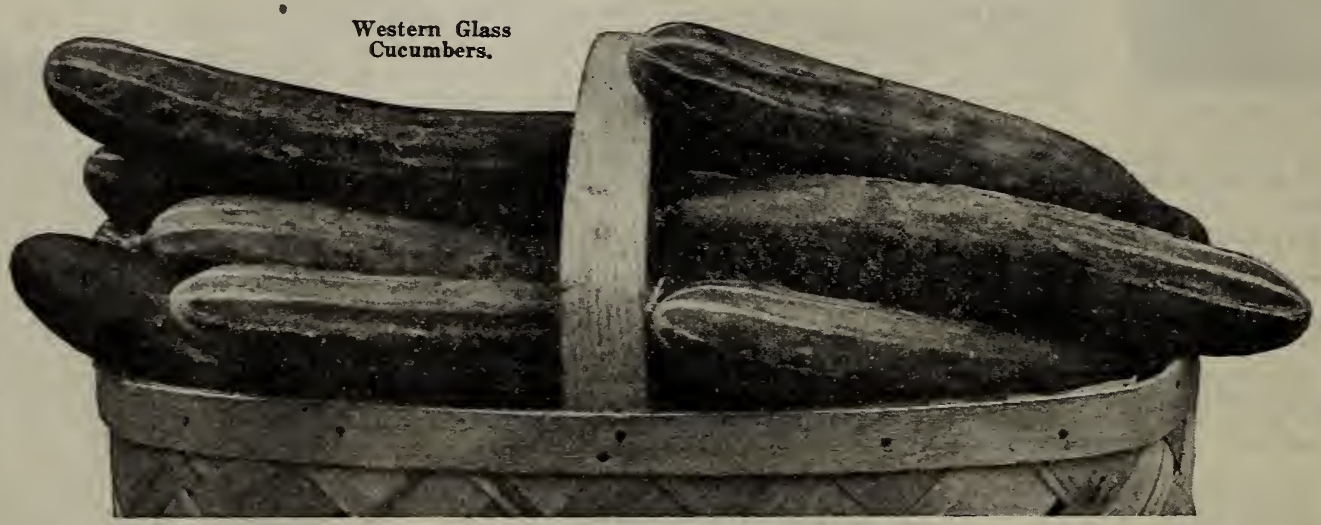

IMPROVED LONG GREEN. The standard cucumber for either slicing or pickling, the Long Green enjoys about twice the wide use of any other. It is extremely prolific, medium late and for hardiness and disease-resistance is the best variety. The ends taper somewhat and it is slightly warted. For general use for all purposes there is no superior to Long Green. The small pickles are well shaped, while in the slicing stage the fruits are very attractive. It is sometimes called "London Long Green." Postpaid, pkt., 5c; large pkt., 10c; oz, 15c; 1/4 lb., 40c; lb., \$1.25.

WHITE SPINE or ARLINGTON. A very productive variety, although not as green nor as long as Davis Perfect, being somewhat thicker than the other varieties. For pickling and slicing combined this is our selection. Postpaid, pkt., 5c; oz., 15c; 1/4 lb., 40c; lb., \$1.25.

JAPANESE CLIMBING. A vigorous grower; can be trained on a trellis; fruits from 12 to 16 inches long, dark green, and smooth; flesh pure white, crisp, and tender. Pkt., 5c; oz., 15c; $1 / 4$ lb., 50c; lb., $\$ 1.50$, postpaid.

Boston Pickling Cucumbers.
KLONDYKE. This sort is a leader in many of the eastern markets for early or late crop. Fruits are of the improved White Spine shape, although they do not show as much white at the tips as the White Spine. They are long, of a deep green color, very productive and extremely early. Postpaid, pkt., 5c; oz., 10c; 1/4 lb., 35c; lb., \$1.25. 


\section{Eggplant}

CULTURE. In February or March, sow in hotbeds and keep warm. When 2 inches high, transplant to pots or to good rich soil, and about the middle of May set out in the open 3 feet apart each way. Eggplant must have deep and thorough cultivation.

BLACK BEAUTY (Gold Seal Quality). Ten days to two weeks earlier than the New York Improved. Fruit a little longer in shape and slightly darker. It is entirely free from spines around the corolla. Is of dark, rich, purplish black color. Very attractive. Slender for either early crop or very late planting. It is a healthy grower and a remarkable yielder. Pkt., 15c; oz., 50c; $1 / 4$ lb., $\$ 1.50 ; 1 b ., \$ 5.00$.

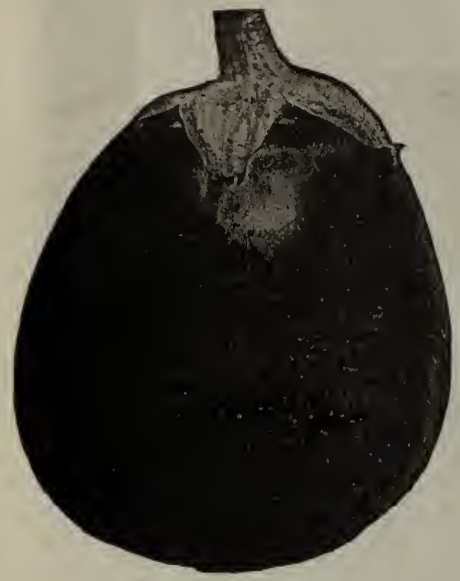

Black Beauty Eggplant.

\section{Kale}

DWARF CURLED SCOTCH. Most popular variety for general use. Leaves much curled and very tender; color bright green. Postpaid, pkt., 5c; large size pkt., 10c; oz., 15c; $1 / 4$ lb., $40 \mathrm{c}$; lb., $\$ 1.25$.

NEW YORK IMPROVED (Gold Seal Quality). This variety is a general favorite for both market and home gardens. The plant is spineless, large, and spreading, with light green foliage. It usually produces 4 to 6 large, oval fruits of a splendid dark purple color. The vigor and productiveness of the plants and the large size, earliness, and fine quality of its fruits, make it a most profitable variety for Market Gardeners. Pkt., 15c; oz., 50c; $1 / 4$ lb. $\$ 1.50 ; 1 b ., \$ 5.00$.

\section{Garlic Sets}

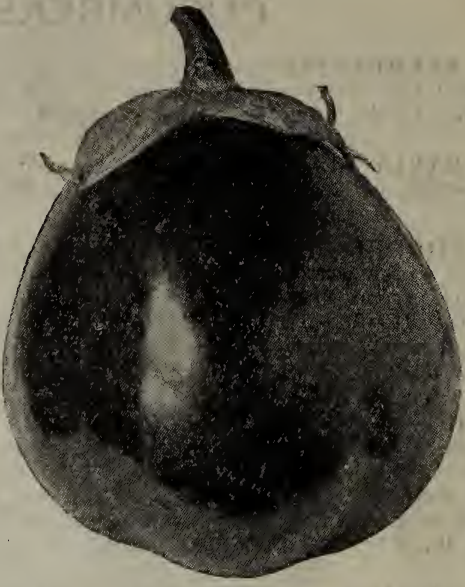

New York Improved Eggplant.

We have a selected lot of good, clean bulbs that will all grow. Those who are fond of this vegetable for flavoring should raise their own supply. $1 / 41 \mathrm{lb}$, $20 \mathrm{c}$ lb., 50c, postpaid. For larger amounts get our special price.

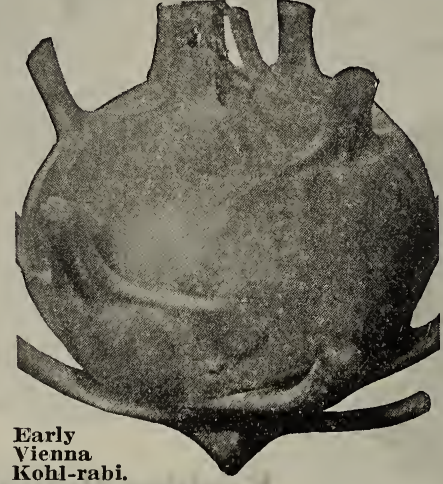

\section{Kohl-rabi}

\author{
(Easy to Grow)
}

CULTURE. This vegetable, when young and tender, is fine for table use; when matured keeps splendidly, and is fine for soup flavoring. For early use, sow in hotbeds, transplant, and cultivate like early cabbage. For winter use, sow in rows in the middle of June or first of July, transplanting or thinning to 8 inches apart.

EARLY WHITE VIENNA. Skin light green flesh white, leaves smooth and short. Well adapted to forcing. Pkt., 5c; oz., 25c; $1 / 41$ lb., 60c.

EARLY PURPLE VIENNA. The swollen stem and leaves are of purplish color; flesh attractive light green. Pkt., 5c; oz., 25c; $1 / 4$ lb., 60c.

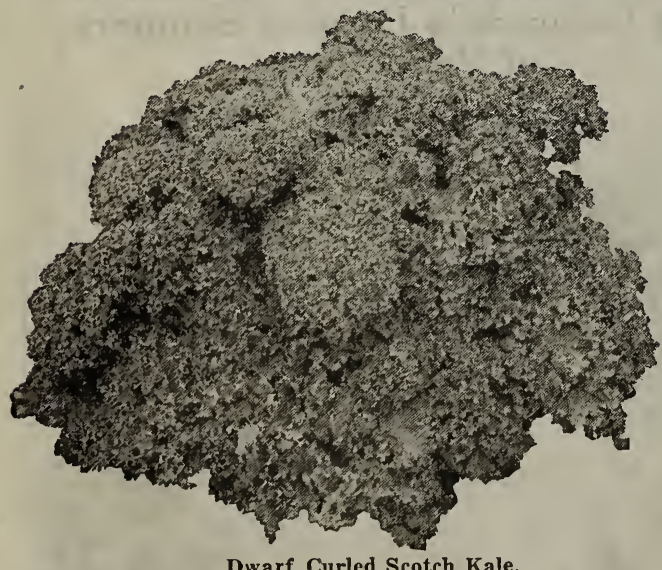

\section{Garden Huckleberry \\ (Wonderberry)}

While classed as a fruit, it belongs in the same family as the tomato and eggplant, being grown and cultivated in the same manner. It is an annual and produces fruit from seed the first year; is very easily grown and succeeds in any good soil. The seed should be started in boxes or cold frames and set out the same as cabbage and tomatoes and yields great masses of rich fruit all Summer and Fall. The fruit is as large as a grape and jet black when ripe. It is fine for cooking, having a flavor like the Huckleberry and makes delicious pies, jellies, preserves, jams, etc. Pkt., $10 \mathrm{c} ; 1 / 4 \mathrm{oz}, 30 \mathrm{c}$.

\section{Leek}

A species of onion which does not form a bulb, but is used for its mild, delicious root stem or neck. Although it is not very well known to the American kitchen, yet wherever it has been tried it has been given a permanent place among the vegetables. It is much sweeter and milder than the onion, being used mostly for flavoring where the onion taste is desired, or it can be boiled the same as boiling onions and served with butter, salt, and pepper. Plant in rows and cultivate the same as onions, except when well grown hill up with earth to get a long white stem.

GIANT CANADIAN. Is the largest species introduced and is very suitable for our district. Prices, postpaid: Pkt., 5c; oz., 25c; $1 / 4$ lb., $75 \mathrm{c}$.

AMERICAN FlAG. A very desirable variety. Prices, postpaid: Pkt., 5c; oz., 15c; 1/4 lb., 50c.

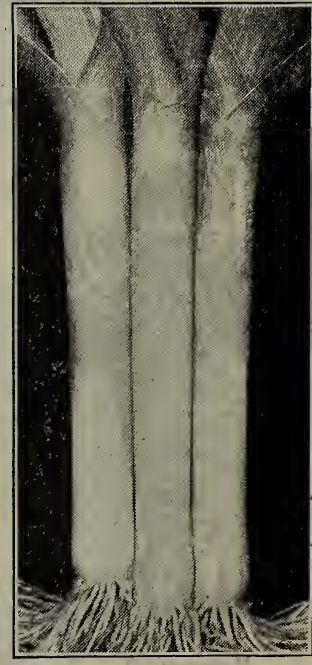

Giant Canadian Leek. 

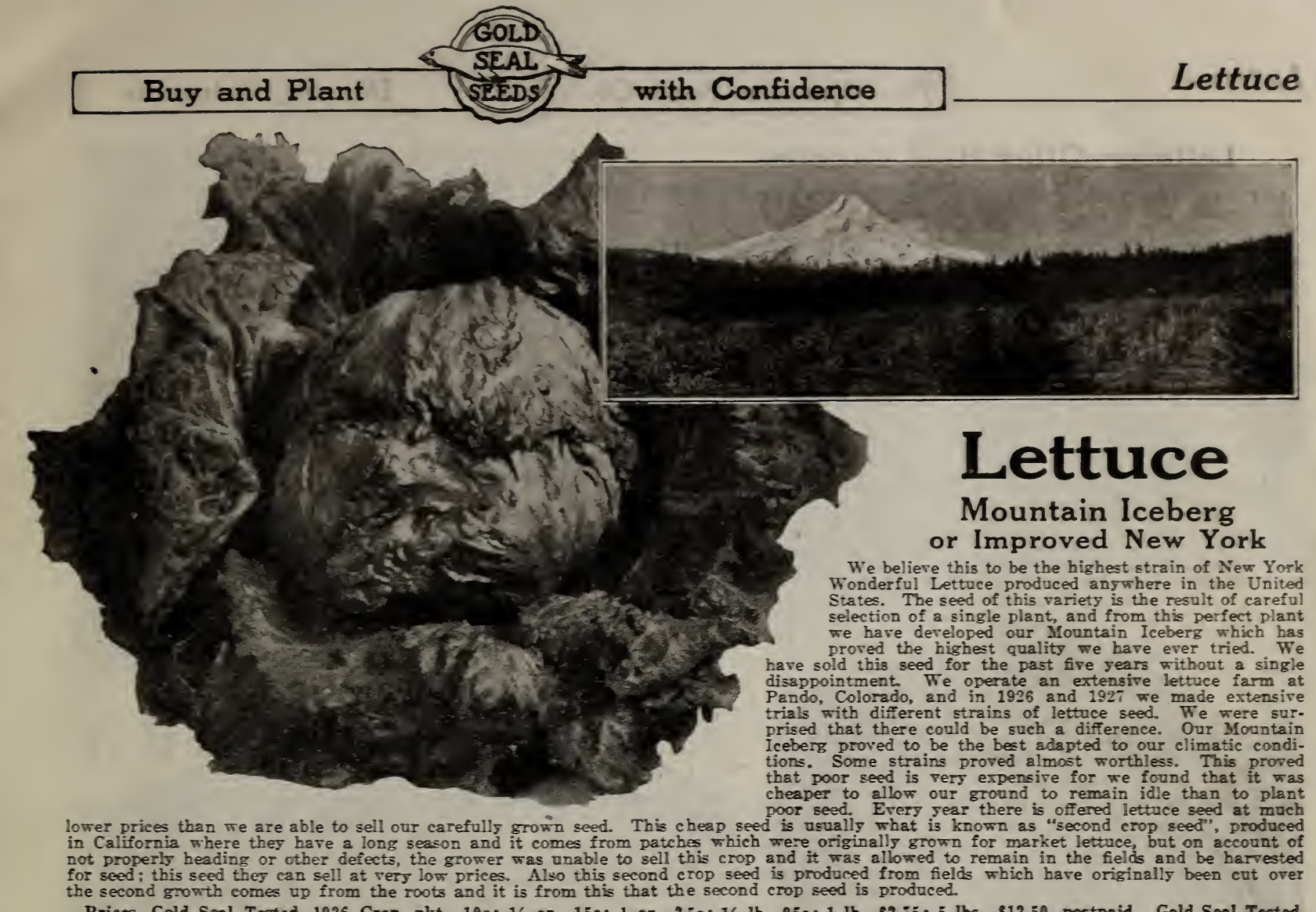

Prices, Gold Seal Tested. 1926 Crop, pkt., 10e; 1/2 0z., 15e; 1 oz., $25 \mathrm{c}$; 1/4 1b., $95 \mathrm{c} ; 1$ lb., \$2.75; 5 lbs., \$12.50, postpaid. Gold Seal Tested, 1925 Crop, 1 lb., $\$ 3.00$; 5 ibs., $\$ 14.00 ; 10$ lbs., \$25.00, postpaid.

\section{Culture of Mountain Iceberg Lettuce \\ By G. D. Isabel, Pioneer of Colorado Lettuce Industry}

This is a crop that requires just as much, if not more close attention, than any garden crop that grows. In our long jears of experience in producing this crop in the high altitudes of Colorado we have found that most failures are made by expecting this crop to mature under conditions required by rougher field crops. The general opinion seems to be that proper climate; that is cool nights, is all that is necessary to produce Iceberg, but there is one more condition that is equally as important and that is soil. Almost as many fields have been lost due to poor soil as from any other cause. Most field Coloredo soils are amply supplied with the mineral fertilizers, all Colorado soils are amply supplied

but most of them are lacking in humus.
For this erop to produce well it must be planted in a location where it will receive warm (not too hot) days, and cool (not too cold) nights. Altitudes ranging from 7000 to 9000 feet in Colorado have prored to be ideal, where the right kind of soil conditions can be found.

Fist of all, it is a vital thing to procure the best and truest strain of seed that is grown. Next be sure that the soll is rich enough to keep erop growing fast, and the higher and colder the location the richer the soil must be.

\section{New York or Wonderful (or Los Angeles} Market) - Best California Grown Seed

This is the same rariety of lettuce as our Improved New York or Mountain Iceberg but it is produced in a different section under some what different climatic conditions than our Mountain Icebeng. It is especially adapted to the growing of erops in Arizona, California, and districts haring an altitude of 6000 feet or less. This variety produce very large, solid heads, the interior of which is beautifully blanched a creamy white, very crisp, and of excellent flavor. The leaves of this head lettuce are somewhat curled. It is one of the surest heading varieties and stands the heat and dry weather better than most sorts. Best

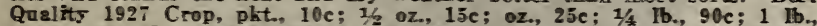
\$2.50. 1925 Crop-Tested Seed, 1 lb., $\$ 2.75$; 5 lbs., \$12.50; 10 Ibs., $\$ 25.00$.

NEW YORK or WONDERFUL (Imported European Grown). While many growers prefer this strain to the Domestic grown seed, we find it quite a different type, producing heads of a much darker green color, also larger and slower in heading. Pkt., $5 \mathrm{c} ; 1 / 202,15 \mathrm{c} ; 1 / 4 \mathrm{Ib}, 75 \mathrm{c}$ $1 \mathrm{lb}$., $\$ 2.25$; 10 lbs., $\$ 20.00$, postpaid.
After the soil is thoroughly plowed and prepared, drill in rows on a compact seed bed 2 feet apart, planting seed one-half to one inch deep, and from one-half to one pound of seed to the acre. Two weeks after it comes up it is usually large enough to be thinned to single plants to a distance of at least 14 inches. Keep crop clean of weeds at all times, but deep cultivation is not desirable in our average Colorado soil. Irrigating should be done with great care. When weather is cold use water very sparingly as crop can be turned to a wellow cast and stunted very easily by too much water. If the sellow cast and stunted very easily by too much water. If the to save the crop by an abundance of water. This crop requires from to save the crop by an abundance of water. This crop requires from difference in time required in different localities being caused entirely by soil and growing conditions of the weather.

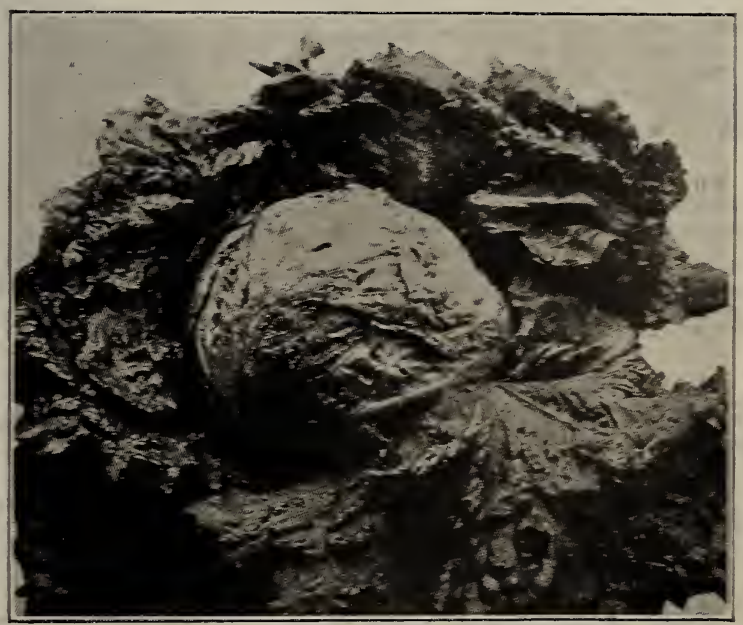

New York or Wonderful or Los Angeles Market 


\section{Lettuce-Other Head Varieties}

LETTUCE CULTURE (Outdoor Planting). Lettuce can be sown either broadcast or drilled in rows, but in either case must be thinned out, leaving the plants about 6 inches a part, so that they may have out, leaving the plants about 6 inches apart, so that they may have room to form a head. Before planting the seed, however, the ground must be thoroughly worked and a perfect seed bed must be prepared. Immediately after the third leaf starts to show start thinning and well-headed lettuce, patches should be hoed and weeded three or four times through the growing period.

CULTURE (For Winter Forcing). Make sowings from September to February. Sow the curled varieties about every four weeks, the Head or Cabbage sort about six weeks apart. As one crop is cut out another may be planted. For early Spring crop sow under glass in January or February, and transplant in the open. For Fall planting, sow the hardy varieties in September and transplant, when large enough to cold varieties in nine inches apart.

ICEBERG. This is not the same as Mountain Iceberg, but is planted in districts where a little warmer weather is experienced. A beautiful lettuce, with large, curly leaves of a bright, light green, with a very slight reddish tinge at the edges. Handsome heads, unusually solid because of the natural tendency of the large, strong leaves to turn in which causes thorough blanching. Crisp, tender, and of fine flavor. Pkt, $5 c$; $1 / 2$ oz., 10c; 1 oz., 20c; $1 / 4$ lb., 50c; 1 lb., \$1.50.
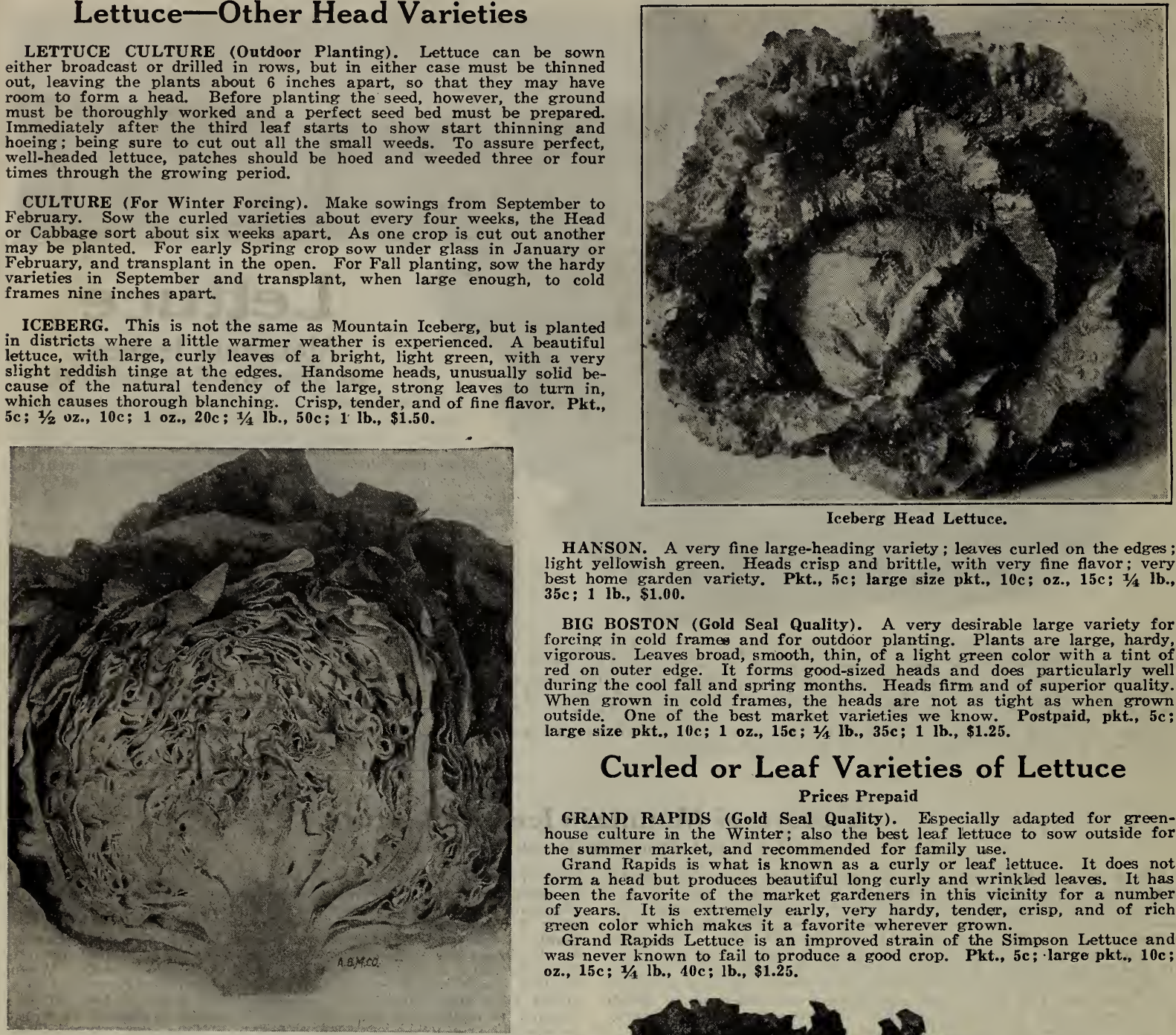

Iceberg Head Lettuce.

HANSON. A very fine large-heading variety; leaves curled on the edges light yellowish green. Heads crisp and brittle, with very fine flavor; very best home garden variety. Pkt., 5c; large size pkt., 10c; oz., 15c; $1 / 4$ lb., $35 \mathrm{c} ; 1$ lb., $\$ 1.00$.

BIG BOSTON (Gold Seal Quality). A very desirable large variety for forcing in cold frames and for outdoor planting. Plants are large, hardy vigorous. Leaves broad, smooth, thin, of a light green color with a tint of red on outer edge. It forms good-sized heads and does particularly well during the cool fall and spring months. Heads firm and of superior quality. When grown in cold frames, the heads are not as tight as when grown outside. One of the best market varieties we know. Postpaid, pkt., 5c: large size pkt., $10 \mathrm{c} ; 1$ oz., 15c; $1 / 1$ lb., 35c; 1 lb., $\$ 1.25$.

\section{Curled or Leaf Varieties of Lettuce}

Prices Prepaid

GRAND RAPIDS (Gold Seal Quality). Especially adapted for greenhouse culture in the Winter: also the best leaf lettuce to sow outside for the summer market, and recommended for family use.

Grand Rapids is what is known as a curly or leaf lettuce. It does not form a head but produces beautiful long curly and wrinkled leaves. It has been the favorite of the market gardeners in this vicinity for a number of years. It is extremely early, very hardy, tender, crisp, and of rich green color which makes it a favorite wherever grown.

Grand Rapids Lettuce is an improved strain of the Simpson Lettuce and was never known to fail to produce a good crop. Pkt., 5c; ·large pkt., 10c; oz., 15c; 1/4 lb., 40c; lb., \$1.25.

\section{Big Boston Head Lettuce.}

DENVER MARKET. While this letruce is classed as a leaf variety, under favorable weather conditions it heads up tairly well. The leaves are long, well zurled and crinkled. It is an excellent home garden variety and a quick grower. Adapted to both arly and late planting. Pkt., 5c; 1 oz., 10c; $1 / 4$ lb., planting. 1 ib., $\$ 1.00$.

PRIZE HEAD, A large, loose-headed variety; leaves are large and very curly, variety ; leaves are large and very curly, bright green color; tinted on the edges with reddish brown and very crisp and
of fine flavor. Not considered very of fine flavor. Not considered very
profitable for the market, but one of the most desired for home gardens. Pkt., 5c; oz., 10c; 1/4 lb., 35c; 1 lb., \$1.00.

BLACK SEEDED SIMPSON. Forms large, loose heads leaves thin and exceedingly tender, of light green color; used for forcing and outdoor planting. Pkt., 5c; large size pkt., 10c; oz., 15c; $1 / 4 \mathrm{lb}$., 35c; 1 lb., $\$ 1.00$.

EARLY CURLED SIMPSON. Also known as White Seeded Simpson; a loose headed variety, leaves much crumpled. Pkt., 5c; oz., $15 \mathrm{c} ; 1 / 4 \mathrm{lb}$., $40 \mathrm{c} ; 1 \mathrm{lb}$., $\$ 1.25$.

COS LETTUCE or SALAD ROMAINE. Much esteemed for its fresh crispness. Leaves are long, smooth, narrow, spoon-shaped, folding into loose heads. Culture same as other lettuces. Pkt., 5c; large pkt., 10c oz., $15 \mathrm{c} ; 1 / 4 \mathrm{lb}$., $35 \mathrm{c}$; 1 lb., $\$ 1.00$. 


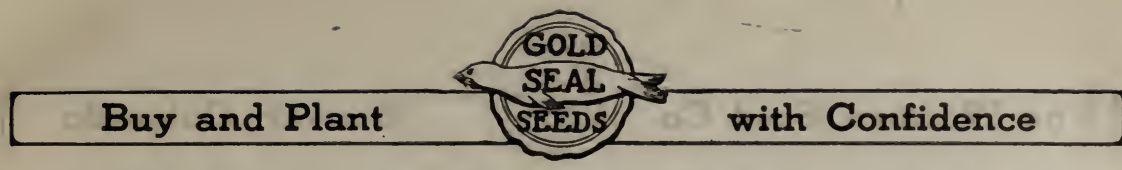

\section{OUR SEEDS ARE COLORADO GROWN

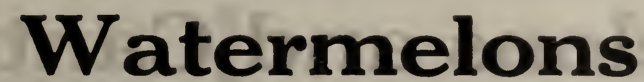 AND TESTED}

PRICES ON MELON SEED ARE POSTPAID

CULTURE. The soil for watermelons must be light, rich, and sandy, for if grown on a heavy soil the quality will be poor, and they will

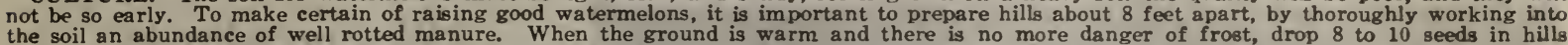

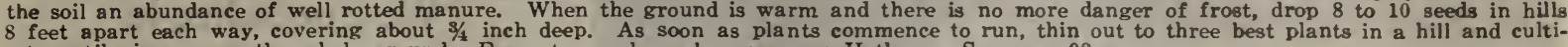
vate until vines cover the whole ground. For extra early melons use our Hotkaps. See pase 92.

KLECKLEY SWEET or ROCKY FORD. The finest of medium early watermelons, and very popular wherever it has been thoroughly tested. It is of superb luscious flavor. While the skin is perhaps too thin to admit of the melon being shipped very great distances to market, it is most desirable to plant for home use or markets. The melons themselves are very large and oblong in form, with dark green skin, oblong in form, with dark green skin, is bright whet with solid heart, deliis bright scarlet with solid heart, delievery way. The melons average from 18 to 20 inches in length by 10 to 12 inches in diameter; of handsome appearance. Ripen early, and are most desirable for the home garden.

Our seed is Colorado grown, and selected from first class, well matured melons, Pkt., 5c; oz., 10c; 1/4 lb., 25c : 1 lb., $75 \mathrm{c} ; 5$ ibs., $\$ 3.25$, postpaid.
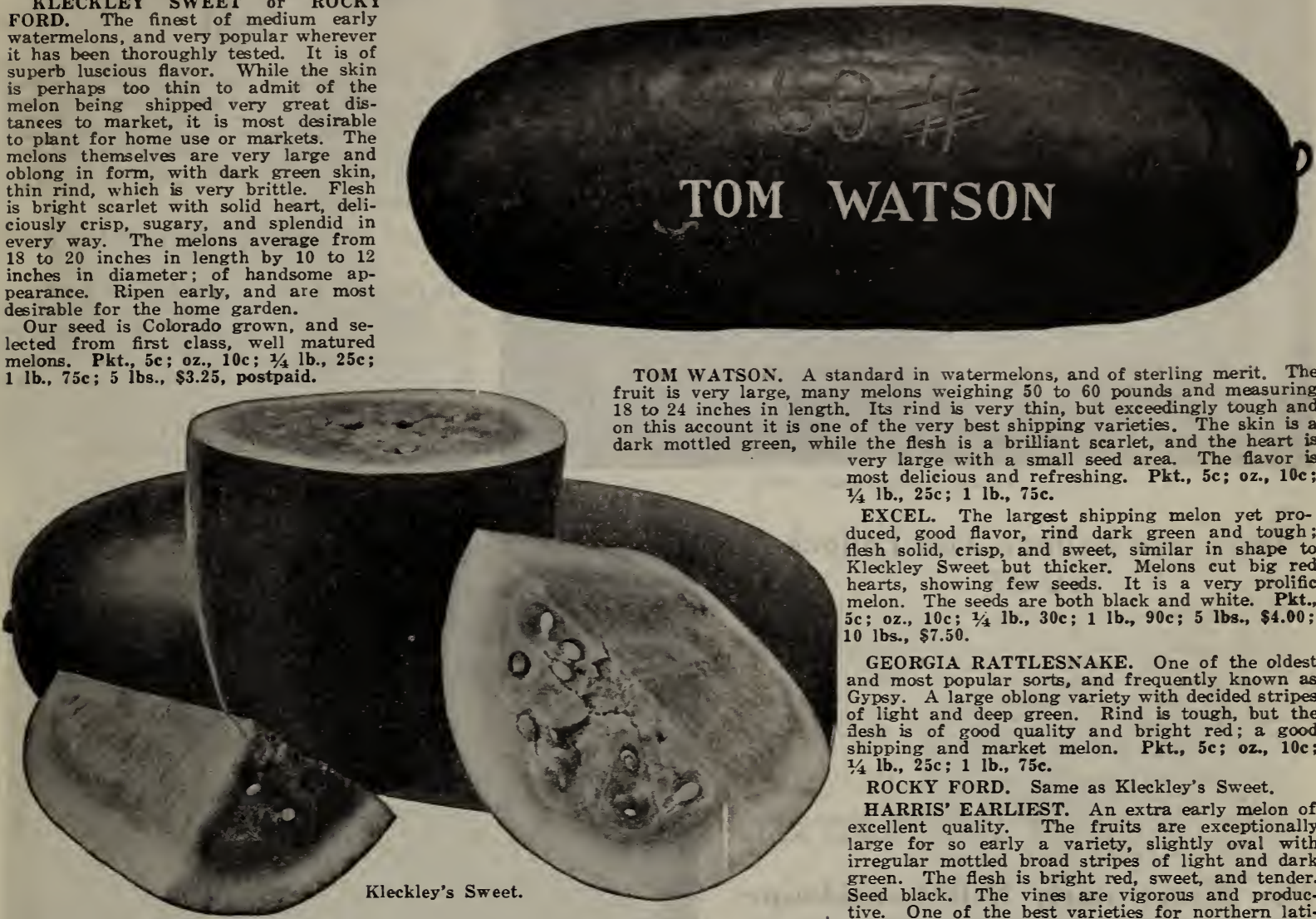

HALBERT'S HONEY. Excels Kleckley's Sweet, which it resembles slightly. The vines are of strong, vigorous growth and many large melons are frequently seen
clustered closely together. The melons average 18 to 20 inches long and are full or a little blunt at the ends. The meat is a deep red color and free from stringinss; seeds white. The combination of a dark green rind, bright red meat without strings, and the delightful delicious flavor make it a favorite. Pkt., 5c; oz., 10c; 1/4 Ib., 25c; 1 lb., $75 \mathrm{c} ; 5$ lbs., $\$ 3.25$.

BLACK SEEDED CHILIAN. An unusual melon of exceptional merit; very solid, extra crisp, and very sugary. A very fine shipping and eating melon, contains but few seeds, flesh firm, and deep red. Pkt., 5c; oz., 20c; 1/4 lb., 50c; 1 lb., \$1.40, postpaid.

ICE CREAM or PEERLESS. One of the best early sorts for the home garden and for the market gardeners who deliver direct to consumers. The vines are moderately vigorous, hardy, and productive. The fruits are very tender, medium sized, oval to medium long, bright green, finely veined with a darker shade. The rind is thin. The flesh is bright scarlet, solid, crisp, and very sweet. Seed white. Pkt., 5c; oz., 10c; $1 / 4$ lb., 25c; 1 lb., $75 \mathrm{c} ; 5$ lbs., $\$ 3.25$, postpaid.

COLE'S EARLY WATERMELON. One of our best early varieties. It is to be classed as a round melon but is slightly oval and of fairly good size for an early sort. The rind is medium thick; the flesh bright scarlet and of excellent flavor. It is termed one of the sweetest melons in cultivation. A dandy melon to grow where seasons are short and the later kinds do not mature. Pkt., 5c; 0z., 10c; 1/4 1b., 25c; 1 lb., 75 ; 5 lbs., \$3.25, postpaid.

JUMBO SUGAR. See inside front cover.

\section{Christmas or Winter Queen Watermelon}

This is a surprise to anyone who grows this melon. It produces good sized melons, almost round and light green to ivory in color. Flesh is bright pink; is exceptionally sweet, in fact most everybody who has eaten this melon claims it is sweeter than any melon grown. Its flesh is very solid, crisp, and juicy. It ripens the first of September and can be kept until Christmas without losing any of its excellent qualities. It is best adapted to sandy soils. Anyone enjoying watermelons should plant some of adapted to sandy soils. Anyone enjoying watermelons sho
these melons. Pkt., 5c; 0z., $15 \mathrm{c} ; 1 / 4 \mathrm{lb}$., 50c; $1 \mathrm{lb} . \$ 1.50$.

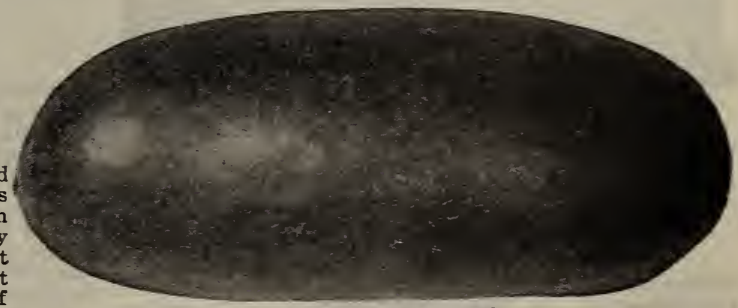
$1 / 4$ lb., $25 \mathrm{c} ; 1 \mathrm{lb}$., $75 \mathrm{c}$.

EXCEL. The largest shipping melon yet produced, good flavor, rind dark green and tough. duced, good crisor, rind dark green and sweet, similar in shape to Kleckley Sweet but thicker. Melons cut big red hearts, showing few seeds. It is a very prolific melon. The seeds are both black and white. Pkt. 5c; oz., 10c; $1 / 4$ lb., 30c; 1 lb., 90c; 5 lbs., $\$ 4.00$; 10 lbs., $\$ 7.50$.

GEORGIA RATTLESNAKE. One of the oldest and most popular sorts, and frequently known as Gypsy. A large oblong variety with decided stripes of light and deep green. Rind is tough, but the Alesh is of good quality and bright red; a good shipping and market

ROCKY FORD. Same as Kleckley's Sweet.

HARRIS' EARLIEST. An extra early melon of excellent quality. The fruits are exceptionally large for so early a variety, slightly oval with irregular mottled broad stripes of light and dark green. The flesh is bright red, sweet, and tender.
Seed black. The vines are vigorous and productive. One of the best varieties for northern latitive. One of the best varieties for northern laticonvinced that it is the very best first early melon. Pkt., 5c; oz., 10c; 1/4 1b.,25c; 1 lb., 75c.

IRISH GRAY. A valuable early melon, for although a grand shipper it is equally fine for the home garden. The color is a distinct mottled gray, flesh red, sweet and crisp and free from stringiness. Our seeds are especially adapted to the West ern country. Pkt., 5c; oz., 10c; 1/4 lb., 35c; 1 lb. $\$ 1.00$; 10 lbs., $\$ 8.50$.

KLONDIKE WATERMELON. Is different from any other melon; grows medium size; remarkable flavor and sweetness; rind thin but tough; the seeds very small; flesh firm. We especially recommend it to people who grow melons for local markets. Pkt, 5c; oz, 10c; 1/4 lb, 25c; 1 lb, 75 ; 5 lbs., $\$ 3.25$, postpaid.

HUNGARIAN HONEY. A new melon imported by us. It is very early and well adapted to short seasons and northern latitudes, Melons are perfectly round, 10 to 14 inches in diameter, and flesh is brilliant red, sweet, and sugary Pkt, $5 c ; 0$

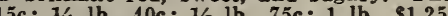




\section{Muskmelons and]Cantaloupes}

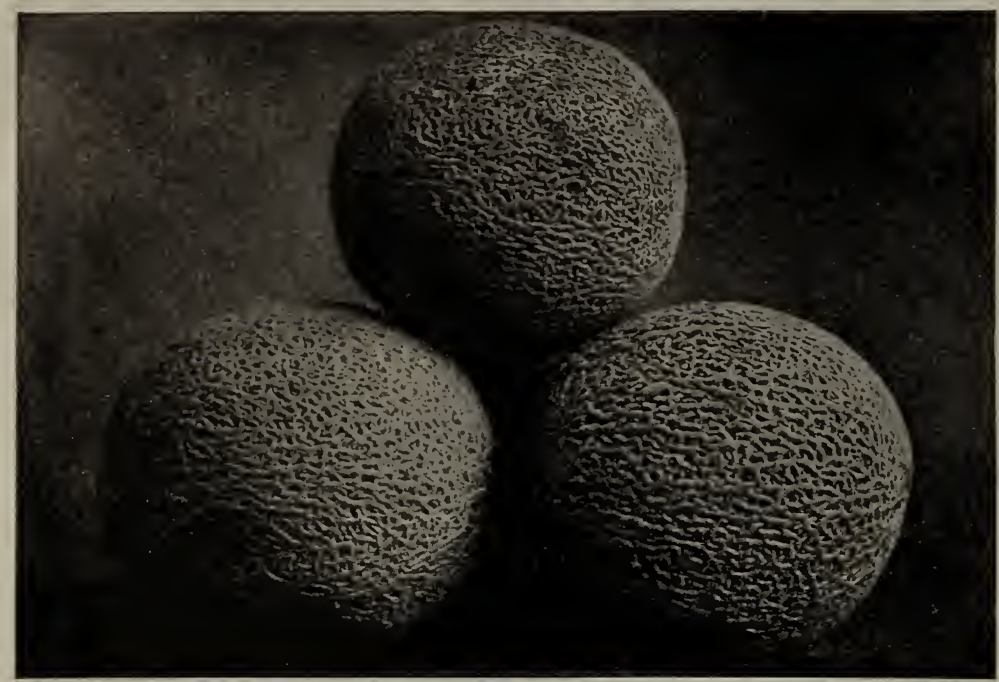

Improved Salmon-Tint Pollock 10-25.

\section{We Specialize in High Grade Cantaloupe Seed}

The Morrison Seed Growers Association, of which Mr. Morrison is the head, have the reputation of producing the best quality cantaloupe seed in Colorado. All their seed is grown on their own farms, under Mr. Morrison's care, and better quality cannot be obtained anywhere. This seed will satisfy the most critical trade and especially those who grow cantaloupes on a large scale for the high who grow cantaloup
class eastern trade.

We are agents for Mr. Morrison's Cantaloupe seed.

CULTURE. A rich, sandy soil and good seed are absolutely necessary for success in raising the best melons. The seed should not be planted until the ground has become dry and warm. Plant in hills 6 feet apart, dropping 8 seeds to the hill. Rich earth is far better than manure but if the
latter is used see that it is well rotted and thorlatter is used see that it is well rotted and thoroughly mixed with the soil. After danger of frost plants to each hill. Cultivate often but not too deep.

\section{Improved Salmon-Tint Pollock $10-25$}

This is the most highly developed of the Rocky Ford Cantaloupes in netting and rust resisting qualities. In the past 4 years, this melon has been planted more than any other variety especially popular in Colorado, Arizona, and California. In size they run mostly standards. The heavy netting is smooth and regular and more prominent than in any other other melon. The stripe so prominent in the old strain of Rocky Ford is almost eliminated. The flesh is of a salmon tint and the quality and flavor is exceptionally fine.

Prices (Morrison's strain): Pkt., 5c; oz., 15c; 1/4 lb., 40c; 1 lb., $\$ 1.25 ; 10$ lbs., $\$ 10.00$, prepaid.

(Morrison's own growing, selected and hand picked), pkt., $10 \mathrm{c} ; 0 \mathrm{oz}, 20 \mathrm{c} ; 1 / \mathrm{t} \mathrm{lb}$., $50 \mathrm{c} ; \mathrm{i} \mathrm{lb}$. to $10 \mathrm{lbs}$., $\$ 1.50$ per $\mathrm{lb}$.; 25 lbs., $\$ 1.25$ per $1 \mathrm{~b}$, prepaid.

\section{New Extra Early H-B Cantaloupe}

The most valuable introduction in the cantaloupe family; there never was a cantaloupe put on the market that gave such universal satisfaction; it is the melon that brought the growers in the Imperial Valley such profitable returns in 1925. The fruits are rather large; oblong in shape and somewhat
ribbed. Flesh is salmon color, fine grained and excellent ribbed. Flesh is salmon color, fine grained and excellent is ten days to two weeks earlier than any other cantaloupe makes it so desirable. Our supply of this seed is limited. Pkt., 10c; oz., 25c; $1 / 4$ lb., $75 \mathrm{c}$; 1 lb., $\$ 2.50$; 5 lbs., $\$ 9.00$, postpaid.

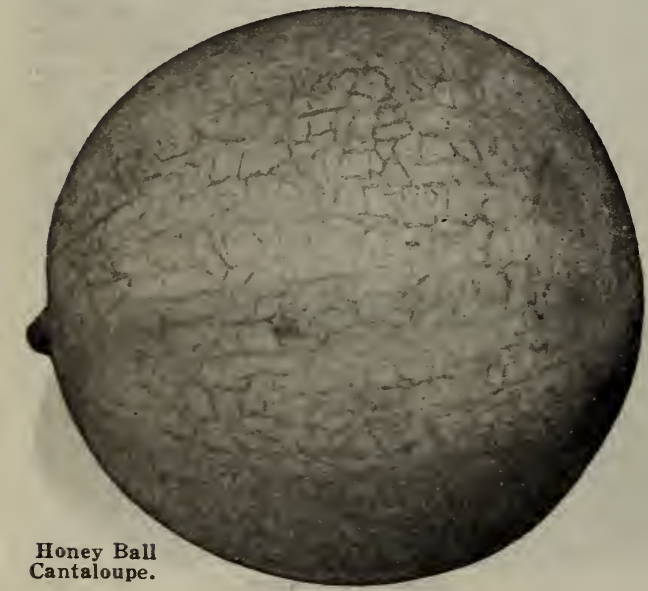

[24]

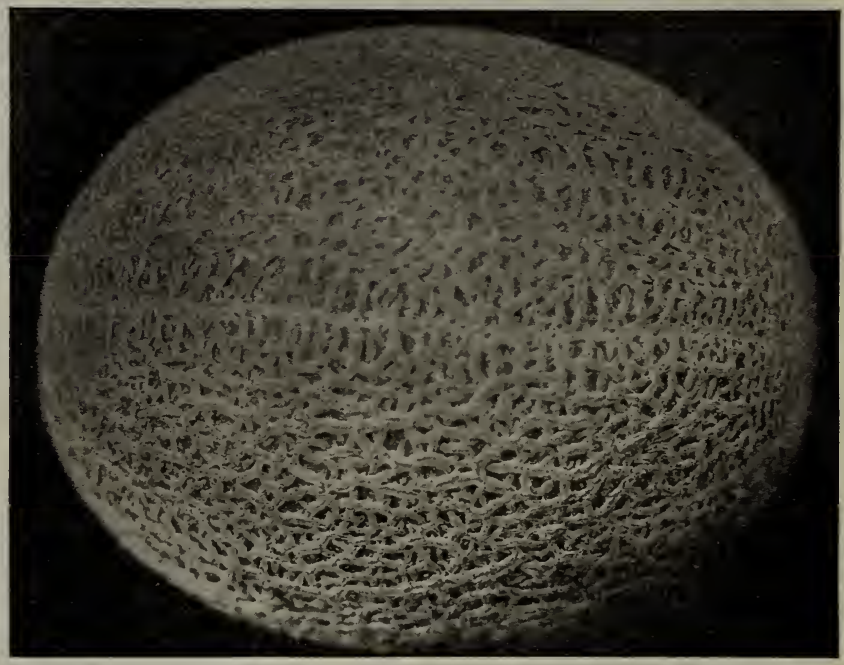

New Extra Early H-B Cantaloupe.

\section{Greeley Wonder Improved Cantaloupe}

It is also one of the earliest muskmelons under cultivation and it produces large melons which resemble the old time muskmelon in shape, having deep ribs, well netted skin and flesh is of richest golden color, one and one-half inches thick, of the finest texture and entirely devoid of coarseness.

It also has a fine flavor, and unlike most muskmelons, instead of tasting what is known as fiat, it is very much like the best Rocky Ford Melon.

Greeley Wonder will yield more than the Rocky Ford Cantaloupe. Don't fail to include some of this variety in your order. See inside of front cover.

\section{Honey Ball Cantaloupe}

Besides its delightful flavor, it will keep for nearly three weeks without spoiling. You can either leave them on the vine until fully ripe, or you can pull them early and store them. In either case they are at their best when the blossom end beand store them. In either case they are at their best when the blossom end be comes soft or gives easily to pressure; they are then fully ripe and make a most
delightful dish. Their keeping quality adapts them splendidly for shipping; they ship as well as any other melon and do not bruise easily.

Honey Ball is a cross between the Honey Dew and a perfectly round, thickly netted melon known as Texas Cannonball. It is earlier than the Honey Dew and about a week later than Rocky Ford, but slightly larger. The vines continue to bear after other cantaloupes are gone. There is probably no melon that will stand hot weather better, nor one that is as little affected by long continued dry weather. Pkt., 10c; oz., 25c; 1/4 lb., 70c; lb., \$2.50. 


\section{Onions}

Prices on Onions Postpaid

CULTURE. A crop of onions can be grown on any soil that will produce a crop of corn, but with the liberal use of manure far better results will be obtained. The ground should be plowed in the Fall and in the Spring should be well worked and pulverized, allowing no lumps or trash to mar the surface. The seed should be sown in the latter part of February or first of March, with a hand seed drill, which should be carefully adjusted so as to sow the desired quantity and about $1 / 4$ inch deep. The quantity of seed needed will vary with the soil, the seed used, and the kind of seed. As soon as they show through the ground give them a very light hoeing, and repeat again in a few days, after which weeding must be done, and must be repeated whenever weeds appear until the tops die down, then they should be topped and the bulbs allowed to dry before sacking.

WHITE LISBON (Gold Seal Quality). For bunching. This is a very popular variety in Colorado. Also planted very extensively in Europe. While it will make a good sized white bulb, it is grown instead of shallots and onion sets for what is known as table or green onions, for when young the white or candle part of the onion is pure white, long, and slender. It has a good flavor, being mild and sweet. Home gardeners usually plant White Lisbon so as to have table onions all during Summer after those produced from sets are gone. Price, pkt., 10c; oz., 20c; $1 / 4$ lb., 65c; 1 lb., $\$ 2.15 ; 5$ lbs., $\$ 10.00$.

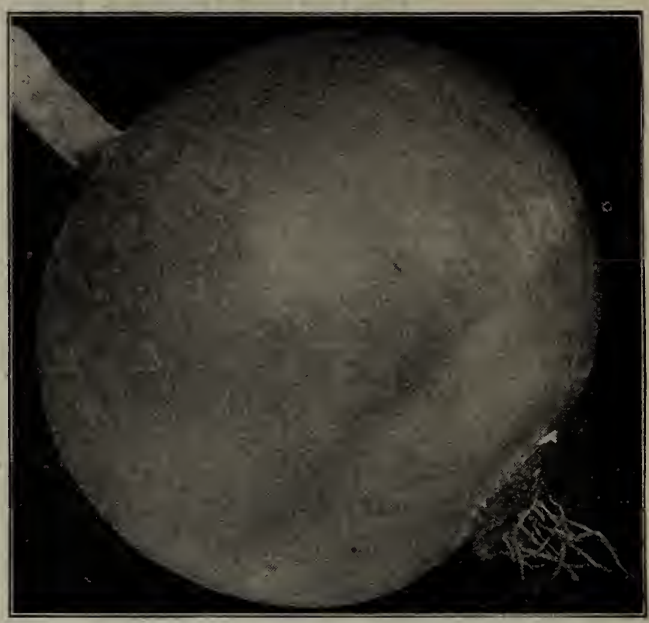

Mammoth Silver King.

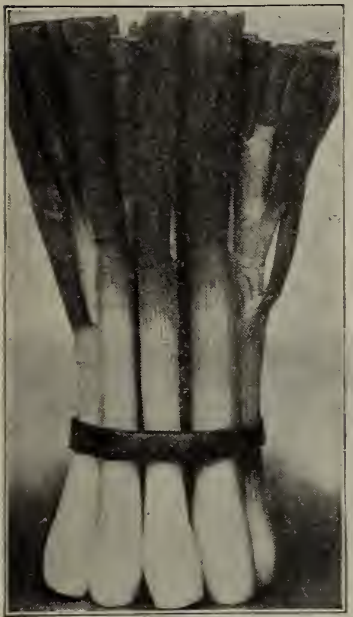

White Lisbon.

MAMMOTH SILVER KING. The largest silver skin onion grown, but not early. It matures along with Danvers Yellow Globe and produces a large, almost round, solid bulb that can be stored for winter use. But on account of its large, perfect shape and pure white color it is planted extensively as a boiling onion, in which case it is pulled green and bunched. Pkt., 10c; oz., 30c; $1 / 4$ lb., 90c; 1 lb., $\$ 2.50$.

EXTRA EARLY WHITE BARLETTA (Imported Strain). The earliest onion in cultivation, maturing when about the size of a marble. On account of its small size and mild flavor it has become the most popular pickling onion grown. And just before it starts to form a bulb it makes an extremely pretty bunch onion. To produce pickling onions, seed must be sown

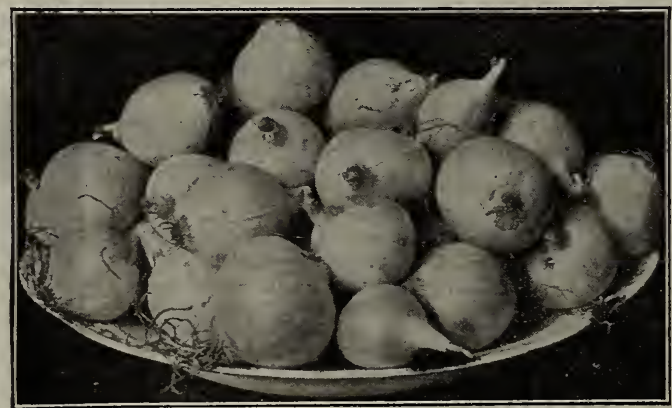

Extra Early White Barletta. very thick. Pkt., 10c; oz., 25c; $1 / 4$ lb., 80 c; 1 lb., $\$ 2.50 ; 5$ lbs., $\$ 11.00 ; 10$ lbs., $\$ 20.00$.

SOUTHPORT WHITE GLOBE. The onions are two to two and a half inches in diameter, with a thin, delicate skin of purest paper whiteness. The flesh is crisp, fine grained, snowy white in color, and very mild in flavor. The bulbs should be stored in a cool, dark loft or shed to dry as soon as they are ripe enough to harvest. Best white winter onion. Pkt., 10c; oz., $30 \mathrm{c} ; 1 / 1 \mathrm{lb}, 90 \mathrm{c} ; 1 \mathrm{lb}$., $\$ 2.75$.

WHITE PORTUGAL. An early white, flat variety of good keeping qualities. Used very extensively as a boiling onion; also grown for a table onion; a favorite with set growers. Postpaid, pkt., 10c; oz., $20 \mathrm{c} ; 1 / 4$ lb., 65c; 1 lb., $\$ 2.25 ; 5$ lbs., $\$ 11.00$.

PRIZETAKER (Gold Seal Quality). We consider this the best onion for the market gardener who desires a large, early onion to supply the early demand and bring good prices which usually follow after the onions grown from sets have been marketed. They produce an enormous yield of large, solid bulbs, and being a Spanish variety, this onion is milder than any of the Danvers. Although it has wonderful merits, it should be marketed before the middle of November, as its keeping qualities are limited to only a few months. Even better results may be obtained from this wonderful onion when the seed is started in hotbeds and transplanted into the open. This onion is often sold in competition with the imported Spanish onion. Pkt., 10 c; oz., 25c; 1/4 lb., 75c; 1 lb., $\$ 2.25 ; 5$ lbs., $\$ 10.00$, postpaid.

WHITE VALANCE, SILVERSKIN. A standard boiling onion of silvery white color forming fine, firm bulbs. It should be planted as a main cropper for boiling onions and the young, tender plants are much relished for table use. Pkt., 5c; large size pkt., 10c; oz., 25c; $1 / 4$ lb., 80c; 1 lb., $\$ 2.50$.

GLANT WHITE ITALIAN TRIPOLI, or EL PASO. A large, beautiful, pure white flat onion of mild, excellent flavor, producing a somewhat larger bulb from seed than our White Valance. To attain full size the seed should be started very early in a hotbed and the plants set out in rich soil. Pkt, $10 \mathrm{c} ;$ oz., 30c; 1/4 lb., 90c; 1 lb., \$2.75.

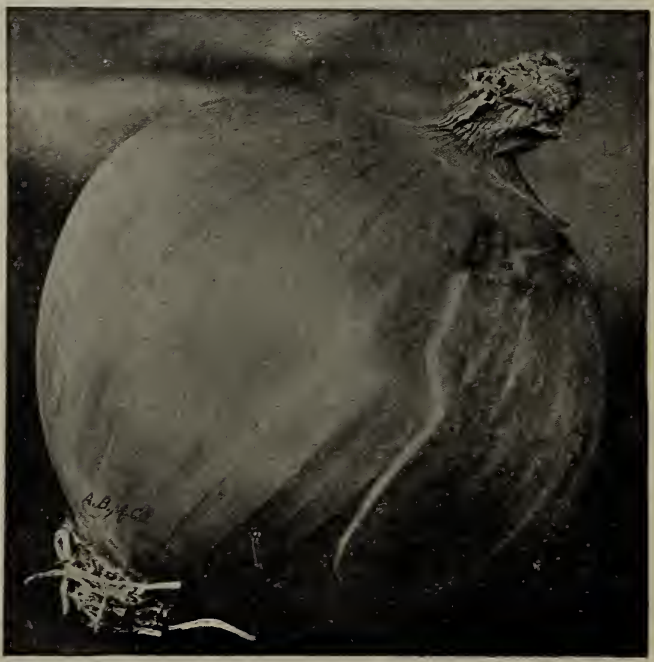

Prizetaker. 


\section{ONIONS-Continued}

YELLOW GLOBE DANVERS. This is a fine, large globe-shaped onion with a rich light brown color. It ripens uniformly and early; almost every plant makes a solid bulb. It is one of the earliest onions to grow as it is of very sturdy habit; produces very few scullions. We do not hesitate to recommend it to all growers who want a fancy and large market onion. While it is not as good a keeper as the David Crockett, yet it can be held until March. We especially recommend this onion to growers who plant large quantities for the shipping trade. Pkt, 10c; oz., 20c; $1 / 4$ lb., 65c; $1 \mathrm{lb}$, $\$ 1.90 ; 5$ lbs., $\$ 9.50$, postpaid.

MOUNTAIN DANVERS. Account of enormous yield of bulbs it is generally considered by onion growers to be the best type of semi-globe shaped onion in existence. It has a distinct and attractive shape, handsome, bright and even in color, ripens early and all at once. Necks are very small. The bulbs are firm and solid, very good keepers. It is especially adapted to heavy soils and short seasons. Pkt., 10c; oz., 25c; 1/4 lb., 75c; 1 lb., \$2.25; 5 lbs., $\$ 10.00$, postpaid.

OHIO YELLOW GLOBE. One of the best yellow globe varieties. The skin is bright, glossy orange yellow; flesh white. The bulbs are remarkably uniform in size and shape and very firm. It possesses good keeping qualities. It ripens a few days later than the Yellow Globe Danvers. Price, pkt., 10c; oz., 20c; 1/4 lb., 70c; 1 lb., $\$ 2.00 ; 10$ lbs., $\$ 20.00$, postpaid.

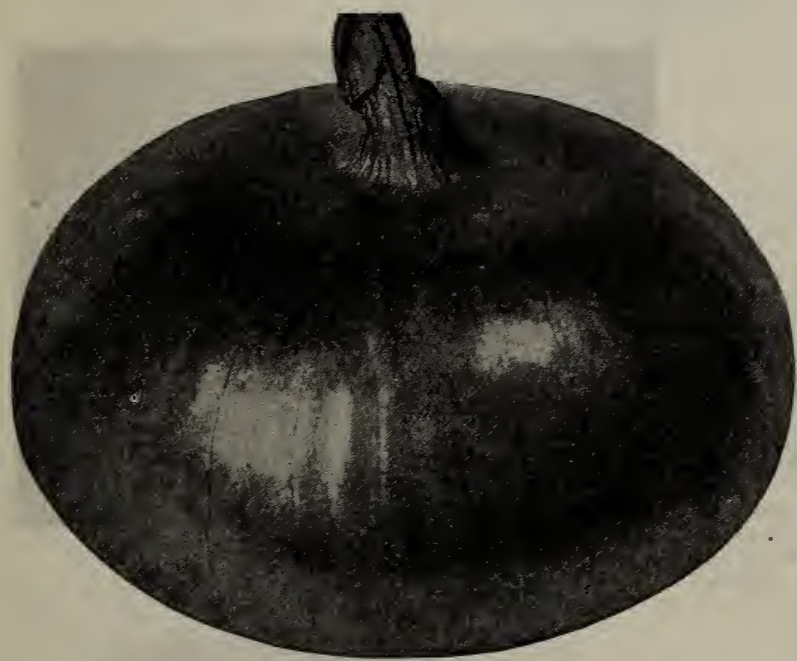

Mountain Danvers.

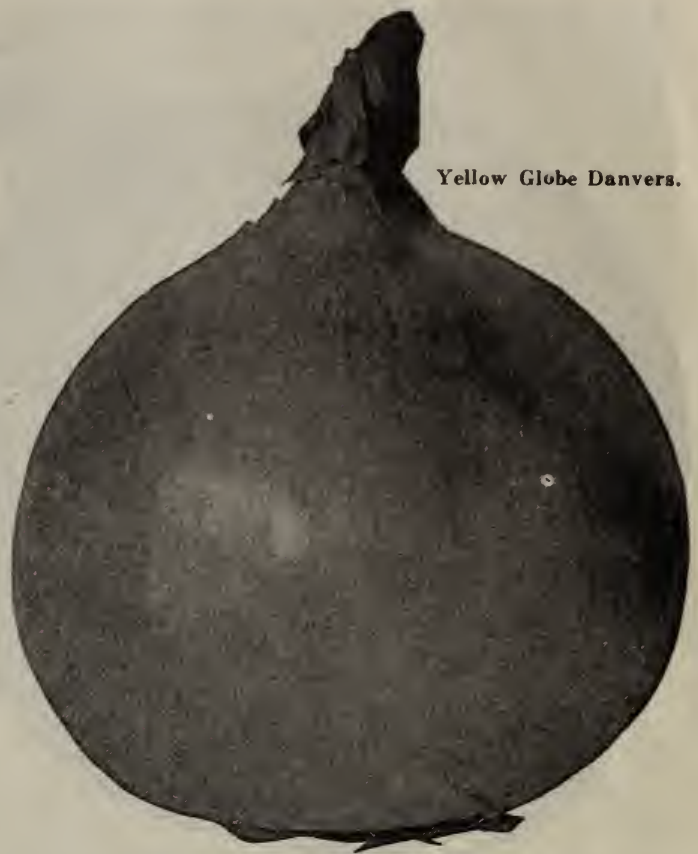

SOUTHPORT YELLOW GLOBE (Gold Seal Quality). Southport, Conn., has for many years been famous for the extra fancy onions which are shipped from that point to the principal eastern markets. These onions have been brought up to the highest standard. Productiveness, uniformity in size and good keeping have been bred into them. They produce large, perfect globe-shaped bulbs, and the color of the skin is brownish yellow while the flesh is white, fine-grained, crisp, and mild. Price, pkt., 10c; oz., 25c; $1 / 4$ lb., $75 \mathrm{c} ; 1 \mathrm{lb}$, $\$ 2.00 ; 10 \mathrm{lbs}$., $\$ 19.00$, postpaid.

YELLOW FLAT DANVERS. A good early onion, both for the home garden and for market, combining reliability in ripening with a large yield. It ripens more surely, as well as earlier, in moist locations than do the globe-shaped varieties. The thin-necked flattened bulbs are quite thick through; light yellow skin; fine-grained, mild, white flesh. Pkt., 5c; oz, 20c; 1/4 lb., 65c; 1 lb., \$1.75; 5 lbs., \$8.00, postpaid.

AUSTRALIAN BROWN. An extra early, sure crop and long keeping onion; of medium size, wonderfully hard; very attractive, both as to form and appearance; color of skin is a clear amber brown, being widely contrasted from any other onion. Pkt, 5c; large size pkt., 10c; oz.,

DAVID CROCKETT ONION. It is the best keeping large size onion grown. We have seen these onions keep well into June the following year; this is due to the very solid flesh. Account of its shape, it outyields all other standard varieties.

The bulbs run very uniform in size, are oval-shaped with a golden bronze skin, and white flesh. The flavor is very pleasant and much milder than most varieties. It is an extremely good keeper. In 1892 Mr. Crockett started this strain by selecting the most perfect ovalshaped, thick-skinned bulbs, improving it each year by careful selection, until this excellent variety was finally obtained. Pkt., 5c; large size pkt., 10c; oz., 20c; $1 / 4 \mathrm{lb}$, 65c; $1 \mathrm{lb}$, $\$ 2.00 ; 10$ lbs., $\$ 17.50$, postpaid.

SWEET SPANISH (Valencia Riverside Strain). Sweet Spanish, as the name implies, is a sweet, mild onion. Until recently this onion was grown almost entirely in Spain and large quantities were imported into this country. There are several different strains, known by the names of the district in Spain where they are grown, as Denia, Gandea, Barcelona, Valencia, etc. The strain which has proved the most satisfactory in this country is Valencia Riverside strain. The name Riverside was added to Valencia because the seed produced at Riverside is far better than any other, being milder, sweeter, more uniform in size, averaging $2 \frac{1 / 2}{2}$ to 3 inches in diameter, covered with good, dark bronze skin. An average yield of 400 sacks per acre and 550 sacks are not uncommon in Colorado. In the A'rkansas valley, they can be drilled right in the fields, but in altitudes and climate equal to Denver it is best to start the plants in hotbeds or coldframes, or we can supply onion plants of this variety. See prices on nnion plants. Pkt., 15c; 0z., 45c; $1 / 4$ lb., $\$ 1.25 ; 1 / 2$ lb., $\$ 2.25$; $1 \mathrm{lb}, \$ 4.00$. postpaid.

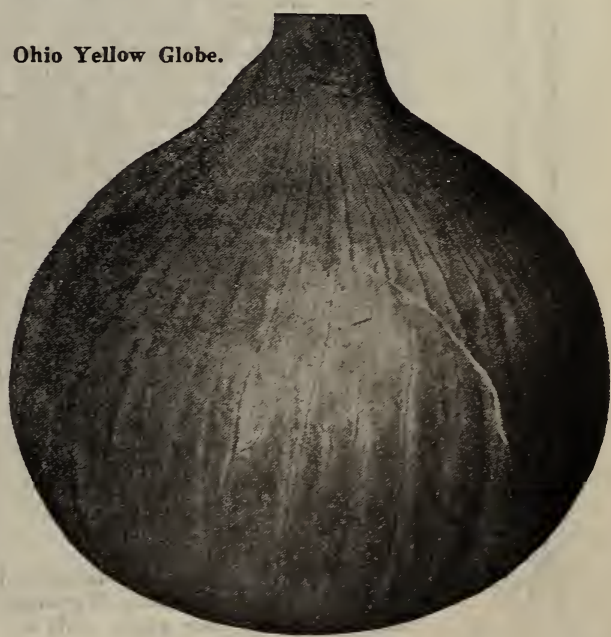




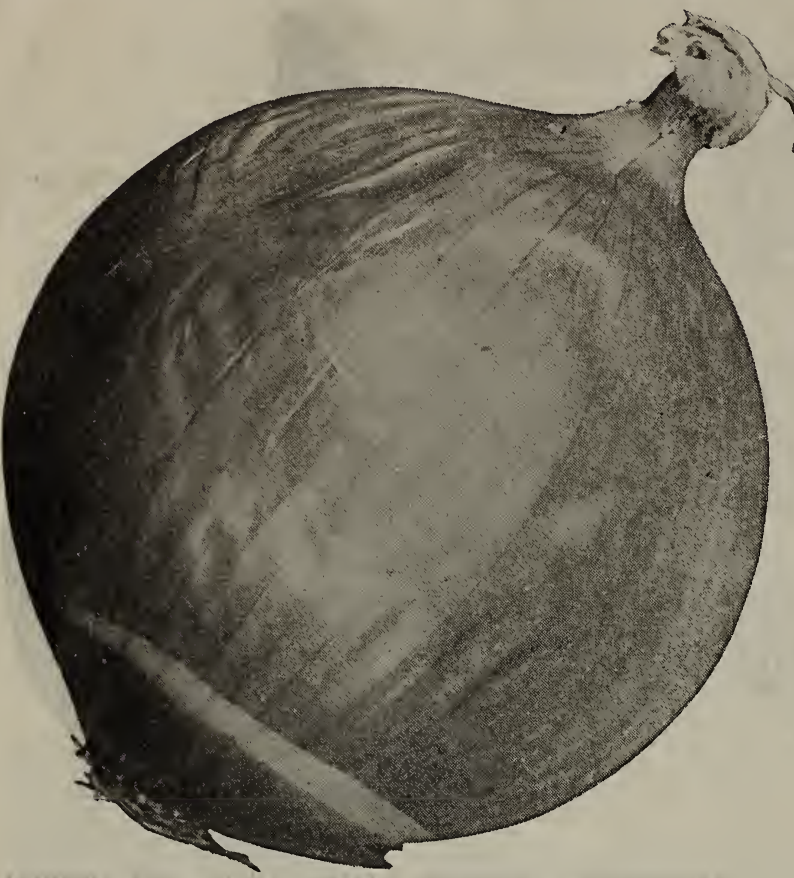

Sweet Spanish-Valencia Riverside Strain.

\section{Bermuda Varieties}

RED BERMUDA. Very flat and of a light pink color. The flesh is white, slightly suffused with pink. Postpaid, pkt., 5c; 1 oz., 25c; 1/4 lb., 90c; 1 lb., \$3.00.

YELLOW BERMUDA. The bulbs are quite broad and flat in form; flesh crisp, solid and mild in flavor; skin is light yellow. The plants are extremely thin-necked, insuring even and early ripening. Postpaid, pkt., 5c; large size pkt., 10c; 1 oz., 25c; 1/4 lb., 90c; 1 lb., $\$ 3.00$.

CRYSTAL WHITE WAX. A pure white variety, very flat and extremely early. It is of the Bermuda type and the best strains come from the Canary Islands from where we get our supply. These are the beautiful White Onions we see in our markets in early Spring. Pkt., 10c; oz., 60c; 1/4 lb., \$1.90; 1 lb., \$6.00.

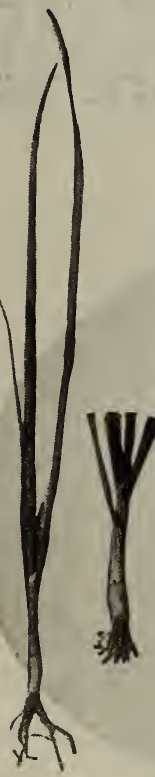

\section{ONION PLANTS}

These are rather new, but in the past three years trials have proved they are a success, and they are replacing dry onion sets, especially where they are grown for green onions for table use, as they produce a large yield of large, dry onions. They are just as easy to grow as onion sets and no higher in price. Many growers find it better and less expensive to use onion plants than to grow dry onions from seed sown in the field. This is especially true of the Sweet Spanish. These plants are field grown, which makes them very hardy; however, all plants deteriorate more or less and in order to save time and have them arrive in the best possible condition, we fill all large orders for a crate or more direct from the growers. For less amounts, we supply from stock which we carry at Denver These plants are put up 100 in a bunch or 6000 in a crate. We will be glad to supply any amount.

Prices by Parcel Post, Prepaid

$100 \quad$ Crate of

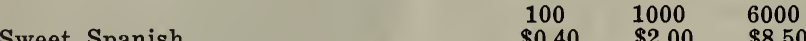

White Bermuda (straw color)

Crystal White Wax ................. $30 \quad 1.90 \quad 7.00$

The above prices are delivered anywhere in the United States except Utah, Montana, Nevada, and Wyoming, where an extra charge of $90 \mathrm{c}$ per crate will be made.

\section{ONIONS-Continued}

DENIA ONION. A large Spanish onion. An enormous It is a very desirable variety with the consuming Gibraltar and skin a little darker. In altitudes

SOUTHPORT RED GLOBE (Gold Seal Quality). The

\section{Red Varieties}

best red onion for the markets, and the only one that should 政 The skin is of the deepest red color and the flesh solid and fine grained. As a keeper it is to be compared to Yellow Globe, for it has been known to hold its color Red Globe. Pkt., 5c; large size pkt., 10c; 0z., 20c; 1/4 lb.

LARGE RED WETHERSFIELD. We have a very fine and lect strain of this sort. Color deep purplish red, flesh c large size pkt., 10c; oz., 20c; $1 / 4$ lb., 65c; 1 lb., $\$ 2.00$;

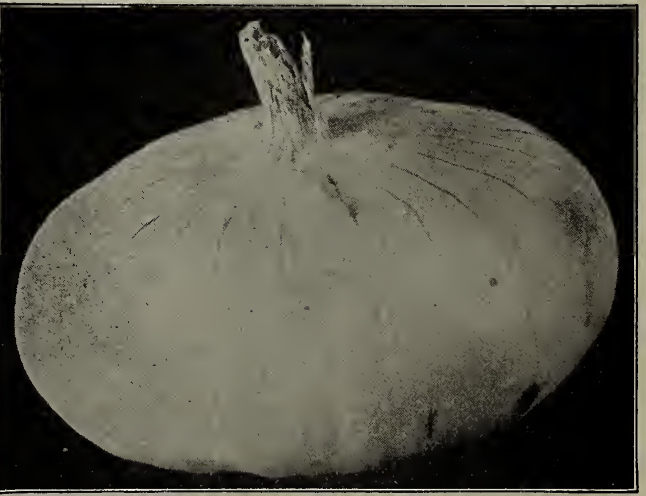

Yellow Bermuda Onion.

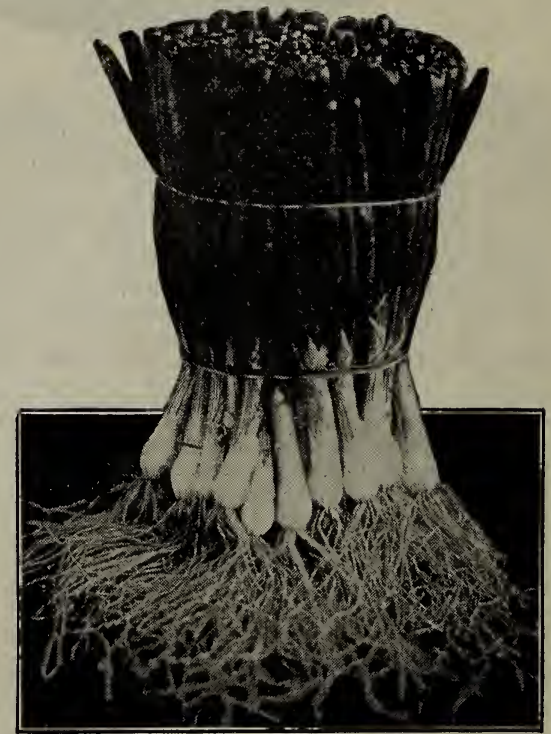

Onion Plants. 


Prices
Are
Postpaid

CULTURE. Peppers should be started in a hotbed or cold frame and transplanted about the end of May into a sunny corner of the garden, in rows about 2 feet apart, with the plants about the same distance between them in the rows. In apart, with the plants about the same distance between them in the rows. In warmer sections they can also be sown in open ground in a prepared seedbed when all danger from frost has passed, the weather has become settled and the soil warm. rows where they are to remain. Some very rich fertilizer stirred into the soil when the plants are about 6 inches high, will be found very beneficial to the crop. The peppers intended for mangoes should not be grown near the hot varieties, or they will partake of their fiery nature.

THE MIKADO (24 to 1$)$. This is, without doubt, the finest large pepper yet introduced. It is a cross between Chinese Giant and Ruby King, fully as early as Ruby King and similar in shape, but broader at blossom end, almost the size of Chinese Giant, and far more prolific, some plants producing as many as 24 marketable peppers. Exceptionally mild, can be eaten raw without fear of burning. Color of fruit green at first, turning to a beautiful shade of scarlet. Flesh thick, which enables it to hold up a long time and makes it an excellent shipper. Pkt., 10c; $1 / 4$ oz., 20c; $1 / 2$ oz., 30c; 1 oz., 50c; $1 / 4$ lb., $\$ 1.50 ; 1$ lb., $\$ 4.50$.

CHINESE GIANT (Gold Seal Quality). This is the favorite when size is wanted, being the largest pepper in cultivation, being double the size of the Ruby King. The plants are vigorous in growth, but of stalky habit, are seldom more than 2 feet in height, producing 4 to 6 peppers of enormous size, thick meated and very mild. On account of its enormous size it meets with ready sale on any market. Although not as early as the Ruby King, it matures in ample time for the heavy demand of the shippers. Large pkt., 10c; 1/2 0z., 35c; 1 oz., 50c; $1 / 4$ lb., $\$ 1.75$; 1 lb., $\$ 5.50$.

RUBY GIANT (Gold Seal Quality). In appearance the fruit somewhat resembles the Ruby King except being larger and a little broadcept being larger and a little broadPepper was introduced to the growPepper was introduced to the grow-
ers in this section by us 7 years ago,
and now it is the most popular pepand now it is the most popular pepper in Colorado. Its dark green has gained it a place in every gar den where peppers are grown for the market. Pkt., $10 \mathrm{c}$; oz., 50c; $1 / 4$ lb., $\$ 1.50 ; 1$ lb., $\$ 5.00$.

BULL NOSE or BELL. Most popular sort, being early and very productive; grows about 2 feet high, fruit remains green a long time. Large size pkt., 10c; 1/2 oz., $25 c$;

ANAHEIM CHILI. A variety produced in California and is largely used both dry and for canning. It is about 7 inches long and has very thick flesh. While this variety belongs to the Chili class, it is not as pungent as some of the smaller sorts. Pkt., 10c; oz., 40c; 1/4 lb. \$1.40; 1 lb., \$4.25.

LONG RED CAYENNE. A well known variety, having a slender, twisted and pointed pod about 4 inches long, bright red in color ; extremely strong. Pkt., $10 \mathrm{c} ; 1 / 4$ oz., 20c; 1 oz., 50c; $1 / 4$ lb., $\$ 1.50$.

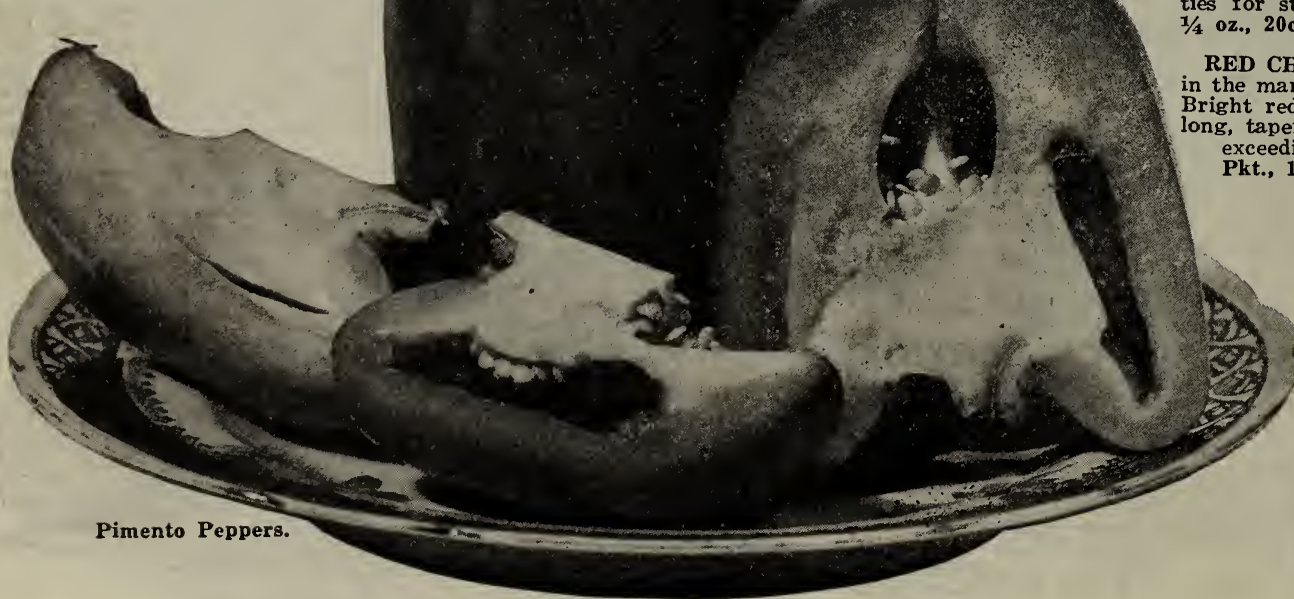

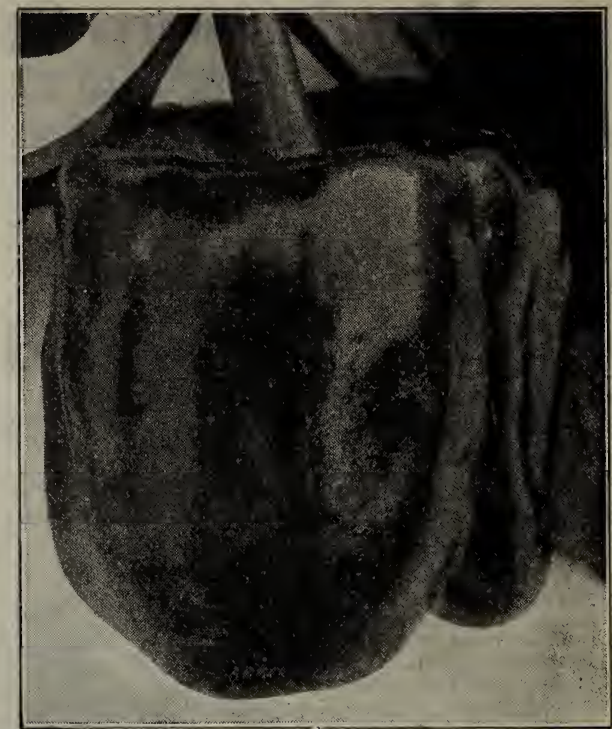

Mikado Pepper.

PIMENTO or SALAD PEPPER. This variety was introduced from Spain. While not as large as the Chinese Giant it is heavier, on account of its extremely thick flesh, which has a mild, sweet, yet deliciously pungent flavor when used either green or ripe. It is being used largely by canners, as its thick flesh allows the skin to be removed, which can be done easily by dipping them in scalding water. When used inem in scalding wild favor and deep in a salad its mild fiavor and deep make it very attractive to the eye as make it very attractive to the eye as
well as to the palate. The plant is well as to the palate. The plant is
very prolific, producing a large number of peppers, each weighing from 5 to 10 ounces. We recommend this new pepper for both the home garden and market supply. Pkt., 10c; oz., 40c; $1 / 4$ lb., \$1.35; 1 lb., $\$ 4.50$.

JERSEY GIANT. This is the earliest of all large peppers, almost as large as Chinese Giant and 3 weeks earlier. Plant of dwarf branching habit, bearing 12 to 15 fruits of a deep green color, turning to brilliant red, flesh thick and of mild flavor. Pkt., 15c; oz., 75c; $1 / 4$ lb., $\$ 2.50$; $1 \mathrm{~b}$., $\$ 8.00$.

RUBY KING. Grows about $31 / 2$ to 5 inches long and is often $21 / 2$ to 3 inches long. One of the best varie ties for stuffed pickles. Pkt., 10c; oz., 20c; 1 oz., 50c.

RED CHILI. A late variety, used the manufacture of pepper sauce. Bright red pods are about 2 inches exceedingly pungent, when ripe. Pkt., 10c; 1/4 lb., 20c; 1 oz., 50c. TABASCO PEPPER. This is the Red Hot Mamma of the pepper family and it is grown for the market as well as for making sauce. It is pungent and strong, also very prolific It is easily cathered as the frily gathered as the fruit does not adhere to the stems and grows almost erect on the branches. This variety is used in manufacturing the well known Tabasco Sauce. It is splendid for family use. Prices, pkt., 10c; oz., 50c; 1/4 lb., \$1.75; lb., 


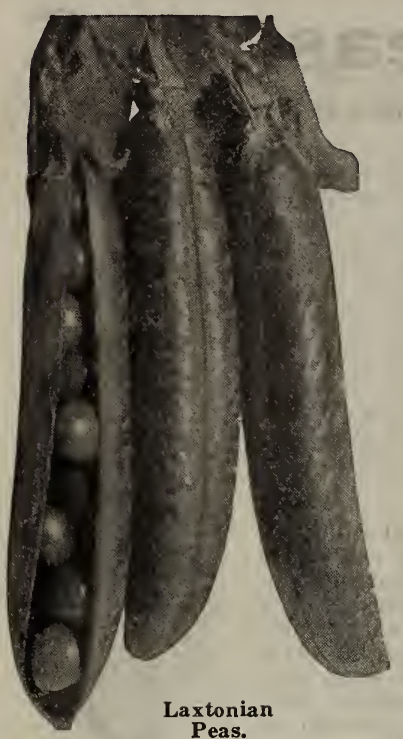

\section{PEAS-Continued}

ALASKA. Is the earliest pea on the market. It is ready 73 days from planting. It is the standard extra early market garden variety. It grows about 30 inches tall, matures a crop of uniform pods 3 inches long. The seed is small, smooth, dark green and of good flavor. Our strain is selected for its earliness and heavy bearing qualities. Postpaid, pkt., $5 \mathrm{c}$; large size package, $10 \mathrm{c} ; 1 \mathrm{lb} ., 30 \mathrm{c} ; 2 \mathrm{lbs}$., $60 \mathrm{c} ; 5 \mathrm{lbs}$., $\$ 1.50 ; 10 \mathrm{lbs}$., $\$ 2.75$. If by express or freight at purchaser's expense, 5c per lb. less. $100 \mathrm{lbs}$., $\$ 16.00$, purchaser paying express.

IMPROVED STRATAGEM (Gold Seal Quality). While not so popular in this district, yet this is one of the best peas to grow, especially in our mountain districts, because it is hardy and is a very heavy vielder of fine, well filled pods which measure about $4 \frac{1 / 2}{2}$ inches long. Vines are dwarf; grows $2 \frac{1 / 2}{2}$ feet high. Matures in 80 to 90 days from planting. Pkt., 5c; large pkt., 10c; 1 lb., 35c; 2 lbs., 65c; 5 lbs., $\$ 1.50 ; 10$ lbs., $\$ 2.75$. If by express or freight, purchaser paying charges, $5 \mathrm{c}$ per lb. less. 100 lbs., $\$ 20.00$, purchaser paying express.

LITTLE GEM. Height, 16 to 18 inches. The vines are of dwarf growth and produce an abundance of round, well filled pods $2 \frac{1}{2}$ to 3 inches long, only three days after the American Wonder. The peas are green, wrinkled, of sweet, delicious flavor and excellent quality. One of the best for family use. It remains fit for use longer than the American Wonder and Nott's Excelsior, and is considered by many to be sweeter. Postpaid, pkt., 5c; large size pkt., $10 \mathrm{c} ; 1 \mathrm{lb} ., 35 \mathrm{c} ; 2 \mathrm{lbs}$., $65 \mathrm{c} ; 5 \mathrm{lbs}$., $\$ 1.50 ; 10 \mathrm{lbs} ., \$ 2.50$. If by express or freight, purchaser paying the charges, $5 \mathrm{c}$ per lb. less.

TALL TELEPHONE. This variety has been the standard for many years past, but is now being replaced by many improved varieties, the main objection being the tall vines. Pkt., 5c; large size pkt., 10c; $1 \mathrm{lb}$., 35c; $2 \mathrm{lbs} ., 65 \mathrm{c} ; 5 \mathrm{lbs} ., \$ 1.50 ; 10 \mathrm{lbs} ., \$ 2.60$. If by express or freight, purchaser paying charges, 5c per lb. less. $100 \mathrm{lbs}$., $\$ 18.00$, purchaser paying express.

THOMAS LAXTON. This is very similar to the Gradus, except pods, which are about one-half inch shorter, but very well filled out. Tests show it to be about 2 days earlier than Gradus. Postpaid, pkt., 5c; large pkt., 10c; 1 lb., 35c; 2 lbs., 65c; 5 lbs., $\$ 1.50$; 10 lbs., $\$ 2.60$. If by freight or express at purchaser's expense, $5 \mathrm{c}$ per lb. less.

GRADUS (Prosperity). The earliest wrinkled variety. This grand, large podded, early, prolific variety has won the favor of market gardeners everywhere. The vines are very vigorous and robust, growing to a height of about 3 feet. It is not only an abundant producer, but bears continually throughout the season. It is exceedingly early for a wrinkled variety, being only a day or two later than the earliest, small, smooth sorts. The pods are very large and are invariably well filled with from 6 to 9 sweet, luscious, tender, wrinkled peas of large size and delicious flavor. The peas remain tender for some time after they are large enough to use. Postpaid, pkt., 5c; large size pkt., 10c; 1 lb., 35c; 2 lbs., 65c; 5 lbs., $\$ 1.50 ; 10$ lbs., $\$ 2.50$. If by freight or express at purchaser's expense, 5c per lb. less. $100 \mathrm{lbs}$., $\$ 18.50$, purchaser paying express.

MAMMOTH EDIBLE POD or LUSCIOUS SALAD PEA. Without an equal for sweetness and tenderness, it is a double purpose pea. The pods when half grown should be sliced and boiled like snap beans and when served with butter or sauce they make a very tempting and delicious dish, or it can be used as a shell pea and is equal to the sweetest wrinkled variety. They are grown the same as any other variety of peas. Pkt., 5c; large pkt., 10c; $1 / 2 \mathrm{lb}$, 20c; lb., 35c; 10 lbs., $\$ 2.75$, postpaid.

FIRST AND BEST. A smooth variety of early, good quality peas. Pods medium size. Matures about same time as the Alaska. Postpaid, pkt. 5c; large pkt., $10 c ; 1 \mathrm{lb}, 35 \mathrm{c} ; 2$ lbs., 55c; 5 lbs., $\$ 1.40 ; 10 \mathrm{lbs}$., $\$ 2.50$. If by express or freight at purchaser's expense, $5 c$ per lb. less.

AMERICAN WONDER. This pea, although it produces small pods, seems to win favor with all planters, as it is a very productive little plant, growing 10 to 18 inches high, and the peas are exceptionally sweet. It is easier grown than most of the large podded varieties. Postpaid, pkt., 5c; large size pkt., 10c; 1 lb., $30 \mathrm{c} ; 2$ lbs., 55c; 5 lbs., $\$ 1.35 ; 10$ lbs., $\$ 2.50$. If by freight or express at purchaser's expense, 5c per lb. less. $100 \mathrm{lbs}$., $\$ 18.00$, purchaser paying express.

\section{For Early Vine Crops}

Use Our Hotcaps

See Page 92

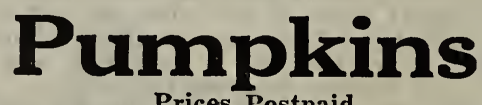

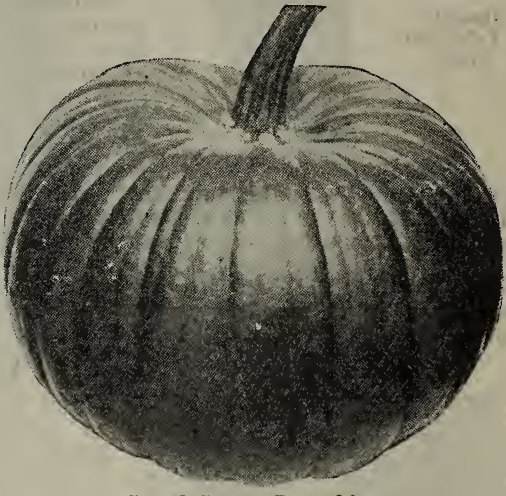

Small Sugar Pumpkin.

Large Amounts Get Special Prices

CULTURAL DIRECTIONS. Sometimes grown in cornfields, but if grown as a separate crop, seed should be planted in hills 8 to 10 feet apart each way after weather and soil get warm. Hoe often till vines begin to run. Cut pumpkins from vine after the leaves die, leaving 3 to 4 inches of stem attached, and store in a dry place. Handle carefully and avoid bruising. Use one ounce of seed to 20 hills of most varieties; 3 to 4 pounds per acre.

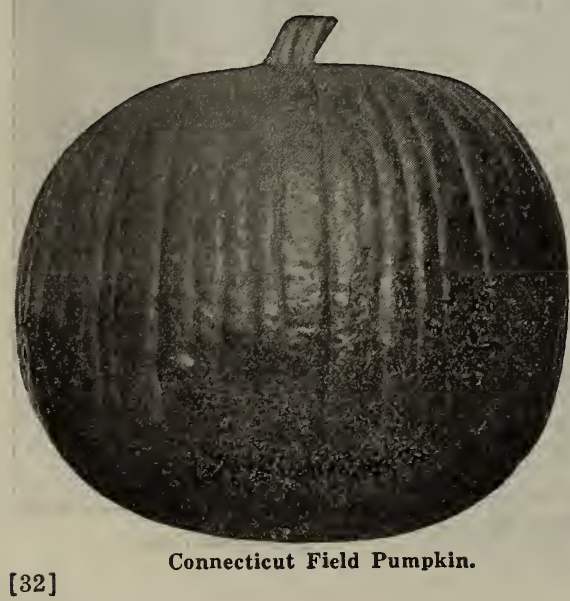

KENTUCKY FIELD (or Large Cheese). A fine pumpkin nearly two feet in diameter. Flesh yellow, extra thick, sweet, and of the finest quality. A heavy yielder and excellent keeper. Prices, pkt., 5c; oz., 10c; 1/4 lb., 25c; 1 lb., $70 \mathrm{c} ; 10$ lbs., $\$ 6.00$.

SMALL SUGAR. A small round variety; flesh thick, rich yellow, and sweet, skin a deep orange. This is the best variety for pies. Pkt., 5c; oz., 10c; 1/4 lb., 25c; 1 lb., $70 \mathrm{c}$.

CONNECTICUT FIELD. A fine large, orange colored variety, used for field culture and stock feeding. Skin smooth and ribbed; flesh brittle. Pkt., 5c; oz., 10c; 1/4 lb., 25c; 1 lb., 75c; 10 lbs., $\$ 6.00$.

MAMMOTH TOURS. A very large French variety, grown for stock feeding. Pkt., 5c; oz., 10c; $1 / 4$ lb., 25c; 1 lb., $80 \mathrm{c}$.

JAPANESE PIE. Large size, weighing from 30 to 70 pounds; color of outside rind bluish-green blotched with yellow. Flesh salmon colored, very thick and sweet; for eating and stock feeding. Pkt., 5c; oz., 15c; $1 / 4$ lb., 40c; $1 \mathrm{lb}$., $\$ 1.25$.

KING OF MAMMOTHS. The best large pumpkin in use, forming immense muskmelon shaped pumpkin, often $2 \frac{1 / 2}{2}$ to 3 feet in diameter; salmon colored; flesh bright yellow. Pkt., 5c; oz., 15c; 1/4 lb., 40c; 1 lb., $\$ 1.25$. 



\title{
SEED POTATOES-Continued
}

EARLY OHIO COLORADO DRY-LAND GROWN. These potatoes are grown for us in the dry lands of Elbert county (known as the Divide). It is our desire to have as many of our customers as possible order our Red River Early Ohios, but those who do not care to pay the advanced price will not be disappointed in our Divide Early Ohios. 5 lbs., 40c: 10 lbs. $70 \mathrm{c}: 25$ lbs. $\$ 1.25$. For larger amounts, write for special prices. If by parcel post, add postage. By express or freight, purchaser pays transportation.

RUSSETT BURBANK. One of the wonderful discoveries of Luther Burbank, and now ranks among the leading varieties of potatoes of the world. For many years this variety has been a great favorite in California, but now it is being grown extensively and with great success everywhere. The Burbank is becoming one of Colorado's best mountain varieties where at one time it was thought only Red McClures would mature and thrive. But the Burbank has proven in this country and on dry land where other varieties have failed, the Burbank has held out against the drought and heat and produced good yields and is now being planted throughout our state on the dry lands. The flesh of the Burbank is white, very mealy, and of fine flavor. The potatoes are long in shape and size, and the skin is russet. As a baking potato it cannot be surpassed 5 lbs, $50 \mathrm{c}, 10 \mathrm{lbs}$ 80c: 25 lbs., \$1.50. For larger amounts, write for special prices. If by parcel post, add postage. By express or freight, purchaser pays transportation.

RURAL NEW YORKER. A valuable variety of large size, very smooth and a heavy cropper. In quality it is unexcelled. It is the best late long keeper, and is highly recommended. More potatoes of this sort are shipped annually than any other kind, and their large, handsome appearance makes them more profitable than any other sort. Planted very extensively in potato districts. $5 \mathrm{lbs}$., 40c; $10 \mathrm{lbs}$., 75c; 25 lbs., $\$ 1.40$. For larger amounts, write for special prices. If by parcel post, add postage. By express or freight. purchaser pays transportation.

\section{ARTICHOKES}

\section{Jerusalem or Potato Artichokes}

Artichokes make an enormous crop of nutritious feed for hogs and cattle. They will yield, ordinarily, twice as much as potatoes on the same land. Should be planted and cultivated the same as potatoes, although, where desired, hogs can be turned on them after 2 weeks after the blossoms, fall, and allowed to feed on the roots throughout the Winter, except when the ground is frozen.

\section{Potato Eyes By Mail Postpaid}

We send these potato eyes delivered to your door. all transportation charges paid, so that all you have to do is to plant them and harvest a crop. We select the seed potatoes, using only the smoothest and firmest stock that we know will carry the longest after being know will carry the longest after being cut. Then we remove the eyes, leaving plant that will produce potatoes. We plant that will produce potatoes. We then pack them in lots of 25 eyes each,
all labeled so as to avoid chance of mixing the different varieties. We guar. antee these potato eyes to arrive in good planting condition. But we advise before ordering the eyes shipped from Denver, that you prepare your soil and have things ready for planting on arrival of stock.

They can be sent without any danger of ped and packed in pasteboard boxes. We, cannot furnish less than 25 eyes of $a$ sort, and those wanting larger amounts should make their orders even multiples of 25 .

Prices (any variety listed):

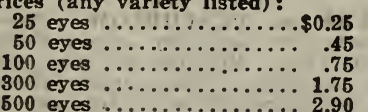

Artichokes are not entirely hardy and it is best not to dig them until ready to feed. They can be planted any time in April, the earlier the better. Plant in rows 4 feet apart, dropping the artichokes 12 to 15 inches apart in the row. It requires 200 inches apart in the row. It requires 200 lib. 15c: 10 lbs. 70 . If by parcel post add regular postage. Write for prices on larger quantities.

\section{SWEET POTATOES}

CULTURE, The plants should be started in hotbeds in March, and after danger of frost, transplanted 2 feet apart in rows $31 /$ to 4 feet apart. They do best in sandy. light soil, and should be cultivated often, especially if supply of water is scarce.

YELLOW NANSEMOND. 1 lb., 25c; 10 lbs., $\$ 2.00$.

YELLOW JERSEY. 1 lb., 25c; 10 lbs. $\$ 2.00$.

If by parcel post, add postage.

On larger amounts of potatoes, get special prices.

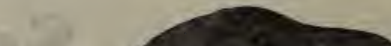

\author{
西 \\ (1)

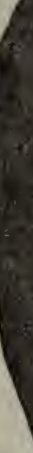




\section{RADISHES-Continued}

FRENCH BREAKFAST (Gold Seal Quality). This is an olive shaped variety and a great favorite for family use and home gardens, as it is very easily grown. The top is of rich scarlet from which color it shades gradually to white at the tip. It should be eaten when medium size. It is a good plan to sow at intervals of 6 or 7 days; this gives young, crisp, solid, and tender radishes throughout the season. Pkt, 5c; oz., 10c; $1 / 1$ lb., 30c; 1/2 lb, 50c; $1 \mathrm{lb.} .90 \mathrm{c}$, postpaid.

SPARKLER (Gold Seal Quality). A splendid variety of the Scarlet Turnip White Tipped type, but showing more white, practically the whole lower part being white, while the upper half is a bright scarlet. It makes a fine show on the market bench, is very attractive and is of good quality. Pkt, 5c; oz., 15c; $1 / 4$ lb., 35c; $1 \mathrm{lb}, 90 \mathrm{c}$, postpaid.

HARTNER'S EARLY WHITE TIPPED (Gold Seal Quality). This is the little round, red radish with the white tip, that is planted in the early Spring and matures in 30 days. The flesh is snow white, crisp, and tender. For the past 12 years we have supplied and satisfied the market gardeners of this section with this special strain. They grow evenly in size and color and produce small tops. It is by far the best round, white tip radish to plant either for the market or the little home garden. If planted at intervals of 10 to 12 days you have fresh, tender radishes throughout the entire Summer. Pkt., 5c; oz., 10c; $1 / 4$ lb., 30c; 1/2 lb., 60c; 1 lb., 90c; 5 lbs., $\$ 4.00$, postpaid.

SPARKLER EARI,Y SCARLET TURNIP, WHITE TIPPED. One of the most attractive and popular of the early turnip sorts. The roots are slightly flattened, the upper portion a deep scarlet and the under portion white, making a beautiful contrast. Our stock of this important variety is true and can be relied on to be the best of its class. Pkt., 10c; oz, 15c; 1/4 lb., 30c; lb., 90c; $10 \mathrm{lbs}$., $\$ 8.00$.

HAILSTONE (Gold Seal Quality). A pure white, round radish of very fine flavor. Pkt., $10 \mathrm{c} ;$ oz., $15 \mathrm{c} ; 1 / 4 \mathrm{lb}$., $40 \mathrm{c}$, postpaid.
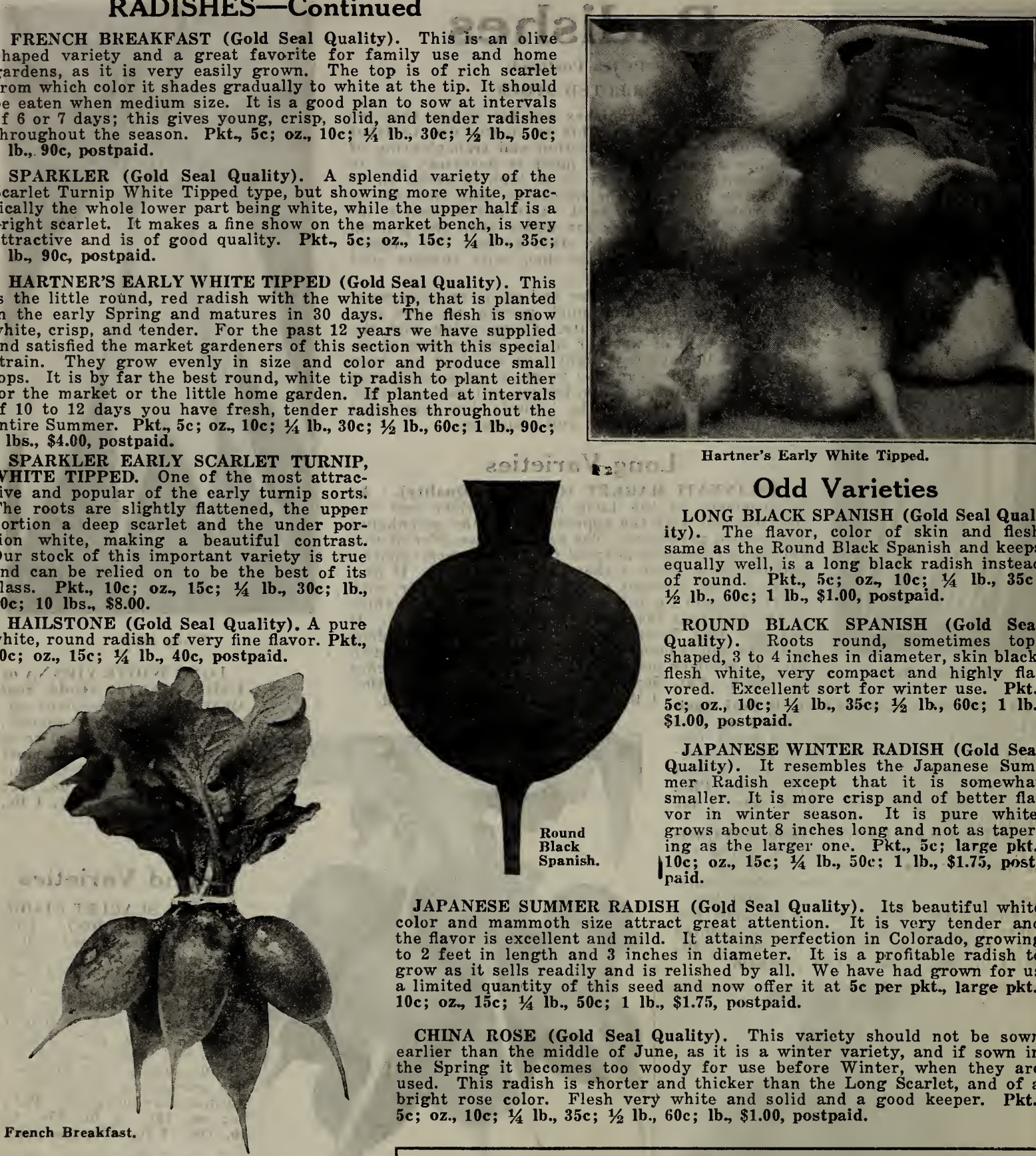

Hartner's Early White Tipped.

\section{Odd Varieties}

LONG BLACK SPANISH (Gold Seal Quality). The flavor, color of skin and flesh same as the Round Black Spanish and keeps equally well, is a long black radish instead of round. Pkt., $5 \mathrm{c} ; 0 \mathrm{Oz}, 10 \mathrm{c} ; 1 / 4 \mathrm{lb} ., 35 \mathrm{c}$; $1 / 2$ lb., 60c; 1 lb., $\$ 1.00$, postpaid.

ROUND BLACK SPANISH (Gold Seal Quality). Roots round, sometimes topshaped, 3 to 4 inches in diameter, skin black, flesh white, very compact and highly flavored. Excellent sort for winter use. Pkt., 5c; oz., 10c; $1 / 4$ lb., 35c; $1 / 2$ lb., 60c; 1 lb., $\$ 1.00$, postpaid.

JAPANESE WINTER RADISH (Gold Seal Quality). It resembles the Japanese Summer Radish except that it is somewhat smaller. It is more crisp and of better flavor in winter season. It is pure white, grows abcut 8 inches long and not as tapering as the larger one. Pkt., 5c; large pkt., 10 c; oz., 15c; $1 / 4$ lb., 50c: 1 lb., \$1.75, post-

JAPANESE SUMMER RADISH (Gold Seal Quality). Its beautiful white color and mammoth size attract great attention. It is very tender and the flavor is excellent and mild. It attains perfection in Colorado, growing to 2 feet in length and 3 inches in diameter. It is a profitable radish to grow as it sells readily and is relished by all. We have had grown for us a limited quantity of this seed and now offer it at 5c per pkt., large pkt., $10 \mathrm{c}$; oz., 15c; $1 / 4$ lb., 50c; 1 lb., $\$ 1.75$, postpaid.

CHINA ROSE (Gold Seal Quality). This variety should not be sown earlier than the middle of June, as it is a winter variety, and if sown in the Spring it becomes too woody for use before Winter, when they are used. This radish is shorter and thicker than the Long Scarlet, and of a bright rose color. Flesh very white and solid and a good keeper. Pkt., $5 c$; oz., 10c; $1 / 4$ lb., 35c; $1 / 2$ lb., $60 c$; lb., $\$ 1.00$, postpaid.

\section{Odd Varieties}

ALL SEASON RADISH MIXTURE (Gold Seal Quality). This is a well balanced mixture of every sort of radishes known and contains only the very best and truest strains. From a bed of our mixed radishes one can have radishes the entire season, for in mixing we include early round, early long, midseason and late varietics. It is quite interesting to have a mixed oed for you will find some sorts you never have seen before. As every seed will grow, we advise that you do not plant too thick so that each plant will thrive and have room to mature. Pkt., 5c; oz., 15c: 1/4 lb., 10c; 1 lb., $\$ 1.00$, postpaid.

\section{No Failures With Gold Seal Quality Seeds}

We wish to again call the grower's attention to the quality of the seed we offer. We do not hesitate to say that better seed cannot be offered as we are sure better seeds are not produced, and you will note our prices are very reasonable. We do very little advertising. We have the largest market garden trade in the West, which trade comes to us on account of GOLD SEAL quality and reasonable prices. 


\section{Squash}

All Prices Postpaid

FOR EARLY SQUASH USE HOTKAPS-SEE PAGE 92.

Squashes are divided into two different classes-summer and winter. Although they neither resemble nor taste alike, both are known as squashes. The majority of the summer varietis are the bush sorts, while the winter varieties are the running sorts.

\section{Summer Varieties}
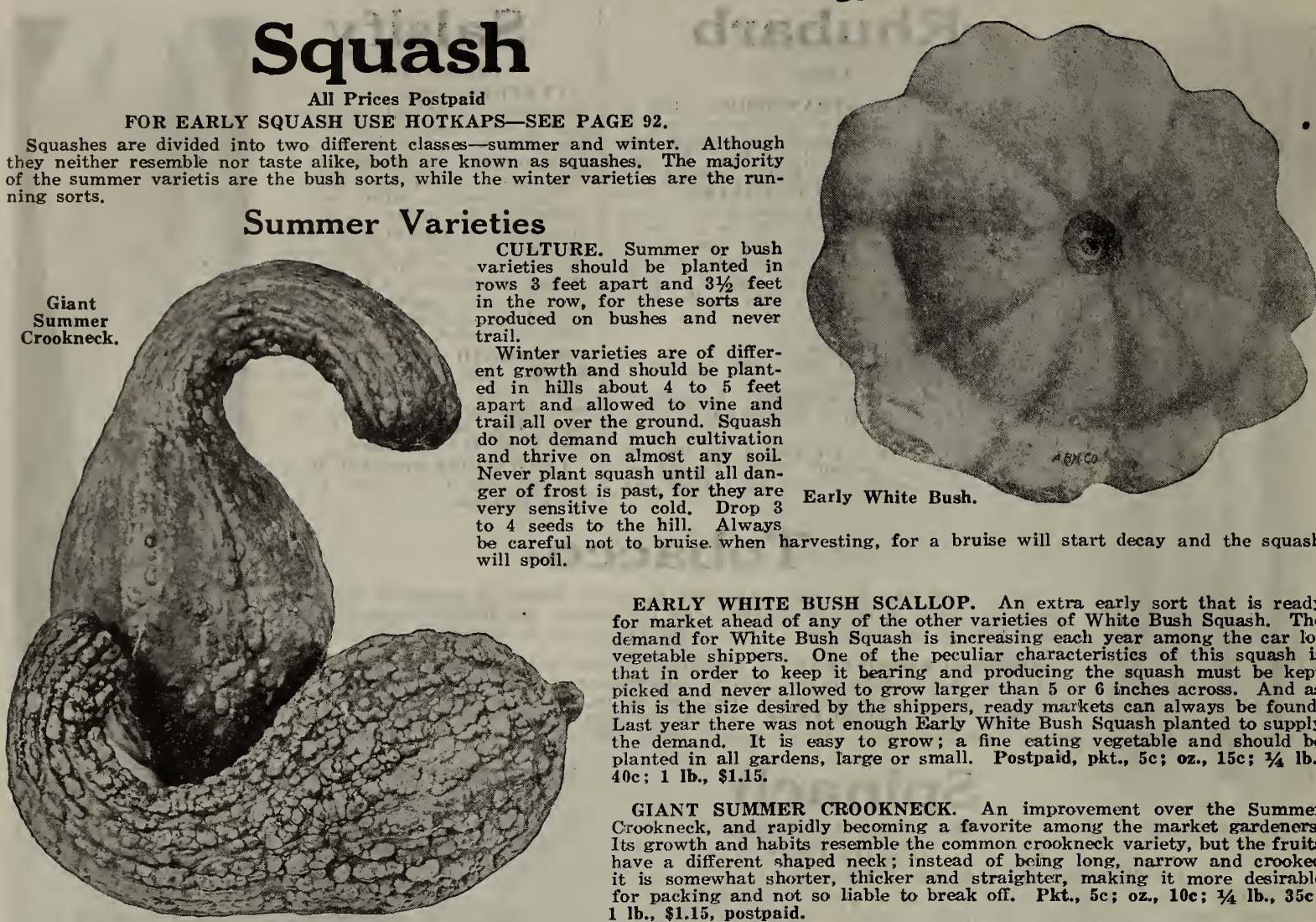
er of frost is past, for they are very sensitive to cold. Drop 3

Early White Bush. be careful not to bruise. when harvesting, for a bruise will start decay and the squash be careful

\section{Winter Varieties}

CHICAGO WARTY HUBBARD. This is the best and most popular strain of the winter squash. When thoroughly ripe its tough, warted shell is as hard as a rock, and the meat is a rich golden-orange color, possessing the highest flavor, only to be compared with that of a sweet potato. Many prefer a good ripe Hubbard Squash baked well done in a hot oven to baked sweet potatoes. Chicago Warty Hubbard, if allowed to ripen will keep in good condition, to ripen will keep in good condition, table all Winter. They are easy to grow, and pay you well for the time and trouble. Pkt., 5c; oz., 15c; $1 / 4$ lb., 40c; lb., \$1.15; 5 lbs., $\$ 5.00$, postpaid.

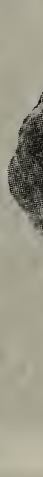

EARLY WHITE BUSH SCALLOP. An extra early sort that is ready for market ahead of any of the other varieties of White Bush Squash. The demand for White Bush Squash is increasing each year among the car lot vegetable shippers. One of the peculiar characteristics of this squash is that in order to keep it bearing and producing the squash must be kept picked and never allowed to grow larger than 5 or 6 inches across. And as this is the size desired by the shippers, ready markets can always be found. Last year there was not enough Early White Bush Squash planted to supply the demand. It is easy to grow; a fine eating vegetable and should be planted in all gardens, large or small. Postpaid, pkt., 5c; oz., $15 c$; $1 / 4$ lb., planted in all gard 1 lb., \$1.15.

GIANT SUMMER CROOKNECK. An improvement over the Summer Crookneck and rapidly becoming a favite among the market gardeners. Its growth and habits resemble the common crookneck variety, but the fruits Its growth and habits resemble the common crookneck variety, but the fruits it is somewhat shorter, thicker and straighter, making it more desirable for packing and not so liable to break off. Pkt., 5c; oz., 10c; 1/4 lb., 35c; 1 lb., $\$ 1.15$, postpaid.

GOLDEN HUBBARD. Very productive; fruits uniform in size, weighing from 6 to 8 pounds. Shaped like the Hubbard; good keeper; shell is Shaped like the Hubbard; good keeper; shell is vkt., 5c; oz., 15c; $1 / 1$ lb., 40c; 1 lb., $\$ 1.25$, postpaid.

VEGFTABLE MARROW. Any one enjoying summer varieties should plant some of this variety as it is exceedingly delicious as well as prolific. Steamed when young or can be fried as an eggplant and is equal to eggplant. The squash is 12 to 14 inches in length, is a creamy color, does not rein length, is a creamy color, does not regood sort for dry lands. Pkt., 5c; oz., 10c; 1/4. lb., 35c; 1 lb., \$1.15, postpaid.

\section{Acorn Squash}

This squash is sometimes called the Des Moines or Individual and is a small acorn shaped squash with dark green rind and is a very choice squash for serving individually by cutting it open lengthwise from stem to blossom end, and after scraping out the seed cavity and placing a large lump of butter in the one half, place the two halves back together and bake them and serve in the shell. Pkt., 10c; oz., 20c; 1/4 lb., 50c; 1 lb., \$1.50.

HUBBARD SQUASH (TRUE). The old standard variety of winter squash, and equal in every respect to the warty in growth, flavor and yield but maand equal in every respect to the warty in growth, flavor and yield, but matures a few days earlier. Practically the only difference is in the skin or shell. rough. Price, postpaid: Pkt., 5c; oz., 15c; 1/4 Ib., 40c; $1 \mathrm{lb} ., \$ 1.15 ; 5 \mathrm{lbs} ., \$ 5.00$.

PIKE'S PEAK or SIBLEY. An excellent winter squash. Fine grained and superior in flavor and keeping qualities to the Hubbard squash, but not so well known. Pkt., 5c; oz., 15c; 1/4 lb., 40c; 1 lb., $\$ 1.25$.

BOSTON MARROW. Is the favorite winter squash of the Eastern states. It is of fine flavor and a good keeper. Pkt., $5 \mathrm{c} ; 0 \mathrm{z} ., 10 \mathrm{c} ; 1 / 4 \mathrm{lb} ., 35 \mathrm{c} ; 1 \mathrm{lb} ., \$ 1.00$. MARBLE HEAD. Of bluish color, sweet and dry. Fine flavored. Shape long and pointed at both ends. Pkt., 5c; oz., 15c; 1/4 lb., 40c; $1 \mathrm{lb}$., \$1.25.

DELICIOUS. This is a splendid variety; more like the Hubbard than any other, but surpasses it in some respects for home use as it is not quite so large. The shell is not so hard; the meat is thicker and of extra fine quality. Pkt., 5c; oz., $15 \mathrm{c} ; 1 / 4 \mathrm{lb} ., 40 \mathrm{c} ; 1$ lb., $\$ 1.25$.

BANANA SQUASH. This is a rather odd squash but a great favorite wherever grown. The squash grows $11 / 2$ to $21 / 2$ feet long and about 9 inches in diameter. The skin is light olive color; flesh beautiful orange and it is recognized as the sweetest squash that grows. When matured it will keep longer than the Hubbard. Pkt., 5c; oz., 20c; 1/4 lb., 50c; 1 lb., $\$ 1.50$.

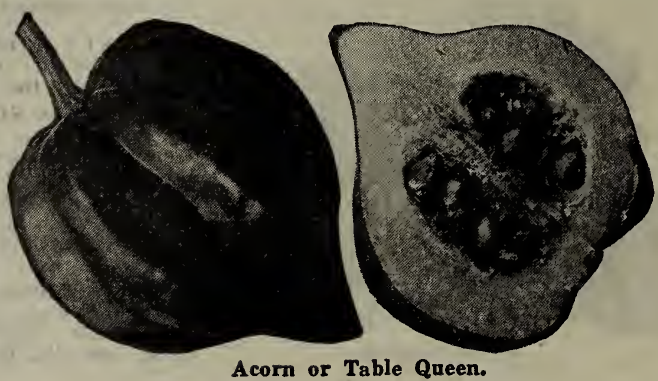




\title{
Tomatoes-Western Grown
}

\author{
Prices on Tomatoes Are Postpaid
}

CULTURE. The best crops are grown in light soil. For extra early fruit the seed should be sown in hotbeds about the first week in March. Sow seed in rows 4 inches apart and not over one-half inch deep. Enough plants for a small garden may be grown in shallow boxes or flower pots in a sunny window in the house. When the weather becomes warm out-of-doors, gradually harden them by exposing them to the air. When all danger of frost is past, set out in the open and water until the plants are established.

BEALTY (Gold Seal Quality). This splendid tomato is without doubt the most widely known and popular of all the purple fruited varieties. A hardy grower, very prolific large, always smooth and a glossy crimson with a tinge of purple; grows in clusters four to six large fruits, retaining its splendid size throughout the entire season quite early, entirely free from ribbed or elongated fuvit: flesh is entire season. Ripen skin and few seeds, seldom rots or cracks after rain ; Picked very firm, has a tough nicely. For the main crop we strongly recommend the Bcked green, it will still ripen eral marketing purposes it has no superior. Our seed is grown from selected stoek and has been tested. It can be depended upon to give the best results. Pkt., 5c; $1 / 4$ oz., $10 \mathrm{c}$;
oz., $30 \mathrm{c} ; 1 / 4 \mathrm{lb}, 90 \mathrm{c} ; 1 \mathrm{lb}$., $\$ 2.75$, postpaid.

THE WYOMING TOMATO. The standard tomato grown in this district the past twentyfive years has been the Beauty, but to tomato planters who grow for the shipping trade it is quite apparent and necessary that they have an earlier and more uniform type of tomato. This improvement we are now able to offer in the Wyoming Tomato, and in addition it is more prolific than the Beauty, stands shipping better, is more uniform in size and free from cracks and cat faces. It bears medium size fruit in clusters of four or five round, solid tomatoes, colored purplish pink. This variety has been thoroughly tried by us and we highly recommend it to growers who raise tomatoes for market and shipping trade. Pkt., 15c oz., 35c; $1 / 4$ lb., $\$ 1.00$; lb., \$3.50.

JUNE PINK (Gold Seal Quality). One of the most satisfactory, extra early varieties, yields as much as Sparks' Earliana and Chalk's Early Jewel, ripening a few days earlier than either of these. The fruit is goor size, smooth, purplish red and are
produced in great abundance. produced in great abundance. for the home garden or loca market, but will not stand shipping, as it is too tender and thin-skinned for this purpose. Pkt., 5e; large pkt. $10 \mathrm{c} ; 1 / 4$ oz, $15 \mathrm{c}$; 102 $1 / 4$ lb., $\$ 1.50 ; 1$ lb., $\$ 4.00$, postpaid.

JOHN BAER (Gold Seal Quality). The John Baer is

the largest extra early tomato grown. It is a very vigorous grower and sets its blossoms quicker than any of the early sorts. grower and sets its blossoms quicker than any of the early sorts, It does not make long vines, but covers the short stalky vines with an abundance of large size, globular, smooth, and uniform tomatoes that ripen quick and are ready for the market one week earlier than the Earliana. The color is a beautiful bright
scarlet. The fruit is coreless and has a delicious sweet flavor, being very solid, and meaty. It often has from eight to ten large, perfect tomatoes in one cluster. Pkt., 10c;0z., 30c; $1 / 4 \mathbf{l b}$. $\$ 1.00 ; 1$ lb., $\$ 3.50$, postpaid.

BONNY BEST. An early scarlet fruited tomato which has proven very successful wherever grown. It matures about ten days earlier than the Chalk's Jewel, is smooth, very even in size and a heavy producer. We recommend this variety for the home garden, canning, and shipping purposes. Pkt., 10c; oz. $30 \mathrm{c} ; 1 / 4$ lb., $90 \mathrm{c}$; $1 \mathrm{lb}$., $\$ 2.75$, postpaid.

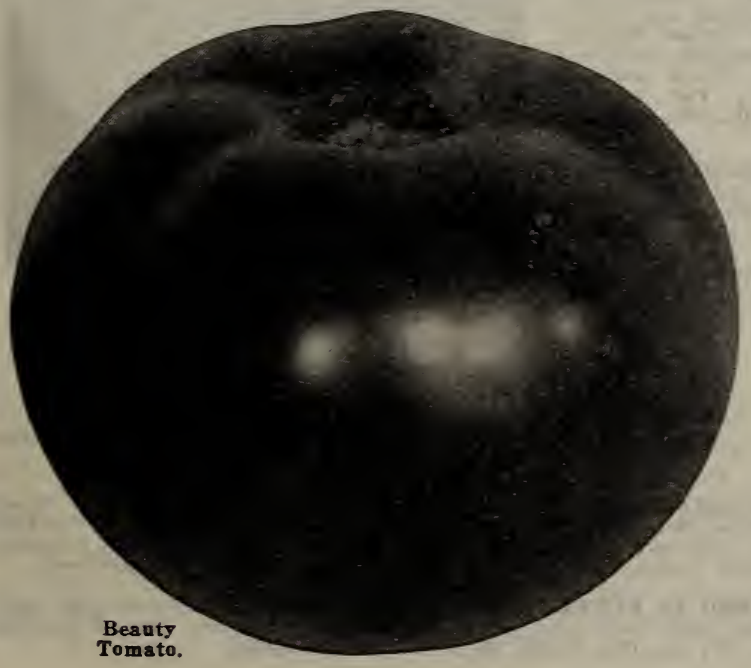

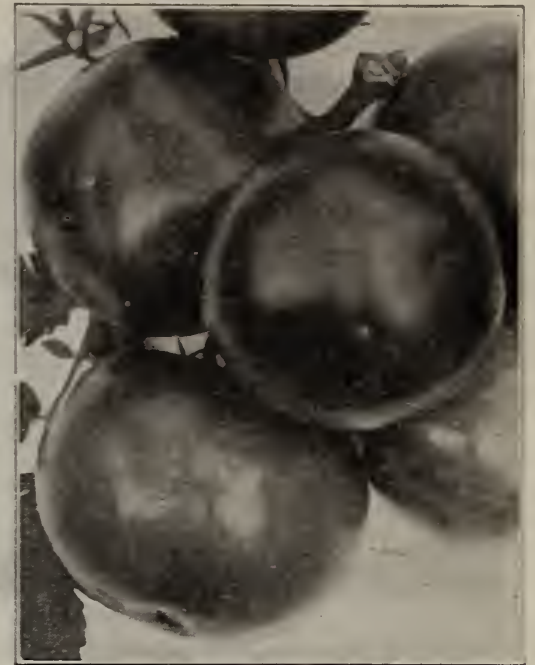

June Pink.

CHALK'S EARLY JEWEL. This is one of the most satisfactory of all early varieties. matures a week to ten days later than the Earliana. The fruit is bright red, very heavy, producing ing an excellent flavor. One of the finest for the home garden and for canning. Pkt., 5c: 1/4 1 ib., $\$ 3.25$.

EARLY BIRD (Gold Seal Quality). This new, extra early tomato is the leading early variety. Its color is dark red, it is of dwarf habit, bears large fruit, and is a heavy producer. Pkt., $\$ 3.50$, postpaid.

DWARF CHAMPION. This is an early, medium sized variety. The fruit is produced in clusters of three to five; having a glossy purple appearance, and are very solid, meaty, and thick fleshed. The plants make a sturdy, upright growth and are frequently called Tree Tomatoes. Pkt., 5c; 1/4 oz., 15c; oz., 30c; $1 / 4$ lb., 90c; 1 lb., \$3.00, postpaid.

PONDEROSA (Improved Strain). Is a purple tomato, of the same color and orade as the Beauty. It is the largest and heaviest practical variety and considered by thousands the best large slicing tomato; bears well throughout the entire season and is a fine sort for the home garden Pkt., 5c; $1 / 4$ oz., 15c; 1 oz., 35c; $1 / 4 \mathrm{lb}$., $\$ 1.15 ; 1 \mathrm{lb}$., $\$ 3.75$, postpaid.

EARLY DETROIT. A second early, medium sized, smooth, handsome, globe-shaped, purple fruited variety. Yields heavier and earlier than Beauty, which it closely resembles. Considered a better main crop Pkt., 10c; oz., 40c; $1 / 4$ lb., \$1.10; 1 lb., \$4.00. postpaid.

ACME TOMATO. Vines are large, hardy, and productive. Fruits are purplish pink, round, smooth, and of a medium size, free from cracks. Although a very good shipping variety, it is also desirable as a hom garden sort. Pkt., 10c; oz., 30c; $1 / 4 \mathrm{lb}$., 90c; $1 \mathrm{lb} ., \$ 3.25$, postpaid.

SPARKS' EARLIANA. A remarkably early tomato. Fruit of good size, red, smooth, and a very heavy yielder. Recommended as an early tomato, but not for main crop. Pkt., 5c; oz., 30c; $1 / 41$ b., $90 \mathrm{c} ; 1 \mathrm{lb}$., $\$ 3.00$.

NEW STONE. One of the best shipping tomatoes, perfectly smooth. There are more Stone tomatoes marketed than any other six varietie put together. It is a sure cropper, fruit larger and more prolific than the Beauty, and the flesh is solid and free from core. Pkt., 5c; 1/4 0z $15 \mathrm{c}$; oz., 35c; $1 / 4$ lb., $\$ 1.00$; 1 lb., $\$ 3.00$.

GLOBE. A beautiful early variety. Has firm flesh, few seeds, ripens early, is very productive and almost blight proof. This tomato shoul be planted more extensively by out-of-door planters for it is early and an abundant producer, of fine flavor and an excellent shipper. As a greenhouse tomato

Small Varieties for Preserving and Pickling

YELLOW PLCM. Yellow, plum-shaped, average one inch in diam eter; excellent flavor. Pkt, 5c; $1 / 4 \mathrm{oz} ., 15 \mathrm{c} ; 1 \mathrm{oz}, 50 \mathrm{c} ; 1 / 4 \mathrm{lb}$., $\$ 1.75$.

YELLOW PFAR. Similar to the Yellow Plum, but fruits are pearshaped. Pkt., 5c; $1 / 4$ oz., 15c; 1 oz., 50c; 1/4 lb., \$1.75.

RED CHERRY. Fruits round, bright red, presenting a beautiful appearance. Pkt., 5c; $1 / 4$ oz., $15 \mathrm{c} ; 1 \mathrm{oz}, 50 \mathrm{c} ; 1 / 4 \mathrm{lb} ., \$ 1.75$.

HUSK TOMATO. For preserving purposes only. Pkt., 5e; $1 / 4$ oz. $15 \mathrm{c} ; 1$ oz., 50c; $1 / 4 \mathrm{lb}$., $\$ 1.75$.

MIXED SMALL TOMATOES. Above four varieties. Pkt., 10c. 


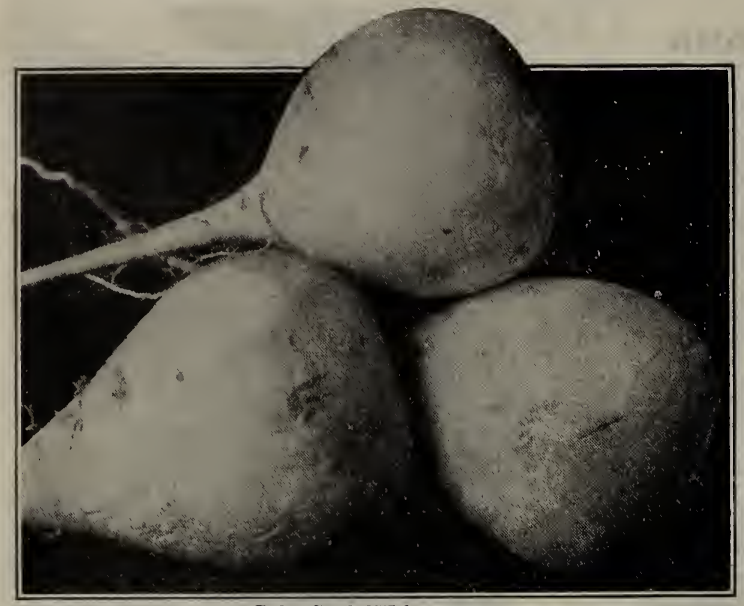

Gold Seal White Egg.

EXTRA EARLY WHITE MILAN (Gold Seal Quality). This is the earliest turnip and is grown exclusively for bunching for the early market. A fiat variety, and for this reason has practically no sale after the globe-shaped sorts are offered. Pkt., 5c; large pkt., 10c; oz., postpaid.

EARLY SNOWBALL. Very rapid grower, being white, and is the first of the globe-shaped sorts. Pkt., 5c ; oz., 10c; $1 / 4$ lb., 35c; 1 lb., 90c, postpaid.

EARLY PURPLE TOP MILAN (Gold Seal Quality). Same as Extra Early White Milan except that about one-third of the turnip is a purplish blue. Pkt., 5c; large pkt., 10c; oz., 15c; $1 / 4$ lb., $40 \mathrm{c}$; $1 \mathrm{lb}$., $\$ 1.25$, postpaid.

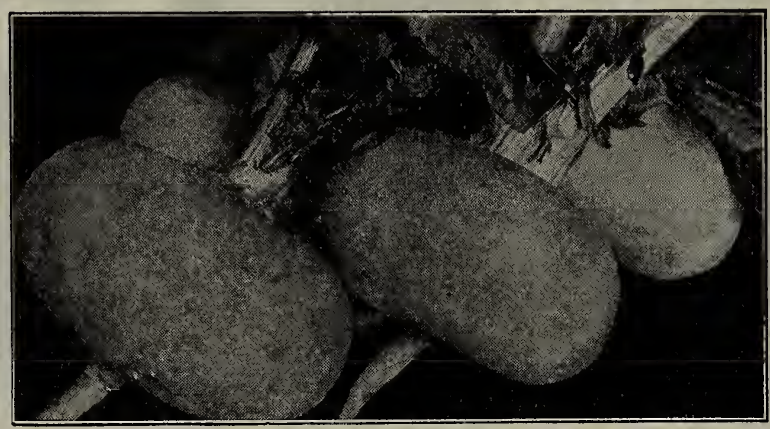

Extra Early White Milan

CULTURE. Turnip is one of the first seeds to be sown in the Spring. As soon as the ground can be worked, spade or plow deeply, and prepare the surface finely, raking off all clods and stones. Sow the seeds at once in the freshly dug soil ; sow very thinly and rake the seeds into the soil one-half inch deep. When up, thin out to three inches apart. Turnips become tough and strong during the hot weather, and the sowing should be so regulated that they will become fit for use, either early in the Summer or late Autumn. For winter use, sow from the middle of July to the end of August.

PURPLE TOP WHITE GLOBE (Gold Seal Quality). The most popular turnip in cultivation, possessing the two qualities looked forward to from turnips ; being both early and sweet. The demand for the Purple Top turnip is becoming greater each year, and in a short time it will be classed among the leading turnips for market gardeners. The flesh is snow white, crisp, sweet, and solid; skin is pure white and smooth except at the crown and shoulders of the turnip; it is colored a rich, reddish purple. A good keeper. Pkt., 5c; oz., 10c; 1/4 lb., 30c; 1 lb., 90c, postpaid.

WHITE EGG ("Gold Seal")-This strain of White Egg turnip is the standard for market gardeners who plant for sacking purposes. It is an unusually quick grower and never fails to produce even size, pure white turnips of perfect shape. After you have harvested your crop early peas, beans, cabbage, lettuce, etc., you will have plenty of time to secure a good crop of turnips of this strain from the same piece of ground. The skin and meat are ground. white as snow, being very as white as snow, being very
crisp, tender and sweet, and it is crisp, tender and sweet, and it is
known as the best turnip for known as the best turnip for
keeping or storing throughout the Winter. Due to its sweet flavor it is regarded as the finest eating turnip under cultivation. Price, pkt., $5 \mathrm{c}$; 1 oz., $10 \mathrm{c}$; $1 / 4 \mathrm{lb}$., 30c; 1 lb., 90c, postpaid.

EARLY PURPLE TOP STRAP LEAF. This is a flat shaped turnip-one-third of the upper portion is purple, balance of the skin is white. In many localities this variety is preferred on account of its fine flavor and it finds a place in many hom gardens. It is not mant hom planted by market extensively Pkt., 5c; oz., 10c; 1/4 lb., 30c; 1 lb., 90c, postpaid.

LONG WHITE or COW HORN. This variety grows large, partly above the ground. Flesh white and sweet. Pkt., 5c; oz., 10c; 1/4 lb., 30c; 1 lb., 90c, postpaid.

DANISH BORTFELDER TURNIP (Largest Turnip Grown). In countries where turnips are grown extensively for feeding purposes, the Bortfelder is a favorite. It grows two are grown extensively for feeding purposes, the Bortelder is a favorite. It grows two feet in length and five inches in diameter, and of cream color fiesh. It is a rapid grower and the most productive of all
oz., $10 \mathrm{c} ; 1 / 4 \mathrm{lb}$., 30c; $1 \mathrm{lb}$., $90 \mathrm{c}$.

POMERANIAN WHITE GLOBE. One of the most productive kinds and in good rich soil, roots will frequently grow eight pounds in weight. Perfect globe shaped; skin white and smooth. Pkt., 5c; oz., 10c; $1 / 4$ lb., 30c; 1 lb., 90c.

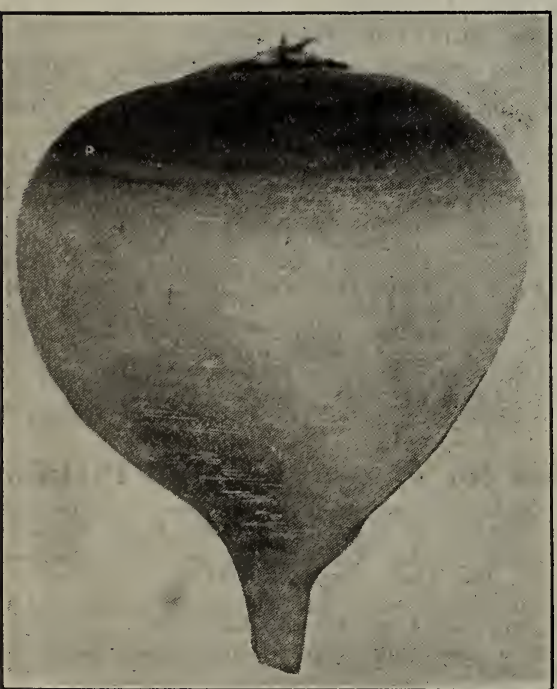

American Purple Top Rutabaga.

\section{Yellow Turnips}

GOLDEN BALL. Undoubtedly among the most delicate and sweetest flavored yellow fleshed turnips, not of large size, but firm, hard and of superior quality. Keeps well and is a fine table sort $\mathrm{Pkt}$. 5c: is a fine table sort. Pkt., 5c; oz.,
$10 c ; 1 / 4 \mathrm{lb}$., 30c; $1 \mathrm{lb}$., $90 \mathrm{c}$, postpaid.

YELL OW ABERDEEN. Very hardy hardy, productive, and a good keeper. Color pale yellow, with purple top, shaped like a globe. Firm in texture, resembling rutabagas. Good oz., 10c; $1 / 4$ lb., 30c; 1 lb., 90c, postpaid.

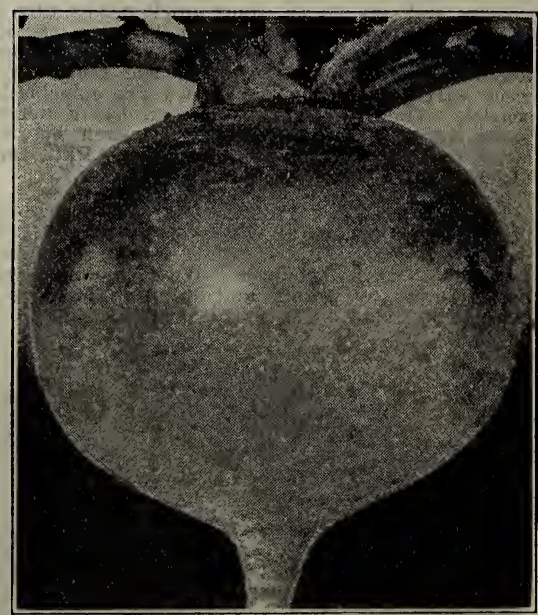

Purple Top White Globe.

\section{RUTABAGAS}

Rutabagas are excellent feed and when fed as mangels they greatly enrich the flow of milk.

BANGHOLM RUTABAGA (Gold Seal Quality). This is the largest rutabaga grown and has been awarded the highest certificate by the Danish government as the best cropping rutabaga. On several trials it has produced as much as 49 tons per acre where it is intensively grown. Pkt., 5c; oz., 10c; 1/4 lb., 30c; 1 lb., 90c, postpaid.

IMPROVED AMERICAN PURPLE TOP (Gold Seal Quality). Very hardy and pro ductive; flesh yellow; sweet and solid Good for stock or table use. One of the best yellow sorts. Pkt., 5c; oz., 10c; $1 / 4$ lb., 30c; 1 lb., 90c, postpaid. 

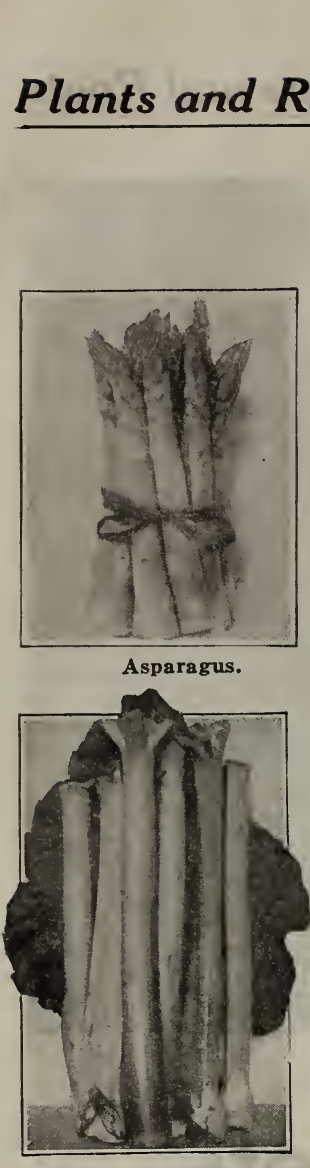

Rhubarb.

\section{Vegetable Roots}

\section{ASPARAGUS ROOTS}

The roots we offer are fresh stock grown from our best strains of imported seeds. We offer both one-year and two-year-old roots, but for good quick results we recommend the two-year-old strong, vigorous roots. The prices on asparagus roots are postpaid. The two best varieties grown in our section are the Palmetto and the Argenteuil; both produce green shoots that are tender from tips to base. We can furnish good, strong plants of the following: Giant Argenteuil, Palmetto, Conover's Colossal, Mammoth White. Good two-year-old roots, 1 dozen, 35c, postpaid; 100 for $\$ 1.50$, postpaid; 1000 for $\$ 10.00$, not prepaid.

MARY WASHINGTON. This asparagus, which has been selected by the United States Department of Agriculture, Washington, D. C., has proven to be nearly rust free. The shoots are thick and heavy. They are long and straight with closely folded tips. The color is rich dark green, tinted darker at the tips. It is a heavy yielder of exceptionally fine flavor. 1 dozen, $40 \mathrm{c} ; 100, \$ 2.00$, postpaid; $1000, \$ 13.00$, not prepaid.

\section{RHUBARB (Pieplant)}

No garden is complete without this old standard. It is easy to start and improves each year. Although we have many varieties we recommend the Strawberry, Giant Red, Large Victoria. We have only twoyear-old roots that will do well in any soil. Each, 10 c; dozen, 70 c postpaid; $100, \$ 3.75$, not prepaid. Write for special price on large amounts.

\section{HORSERADISH}

This is one of the hardiest vegetables for the garden or farm. It gives results the first year. The larger roots can be taken up and stored for winter use. If grown for the market you will find it very profitable. 1 dozen roots postpaid, $20 \mathrm{c} ; 100$ roots postpaid, $\$ 1.25$. For larger amounts get our special price.

\section{JERUSALEM ARTICHOKES}

The culture of the artichoke is similar to the potato, hence the name: "Potato Artichokes." For description see page 57. Price, 1 lb., postpaid, $15 \mathrm{c} ; 10 \mathrm{lbs}$., postpaid, 70c. Write for prices on large amounts.

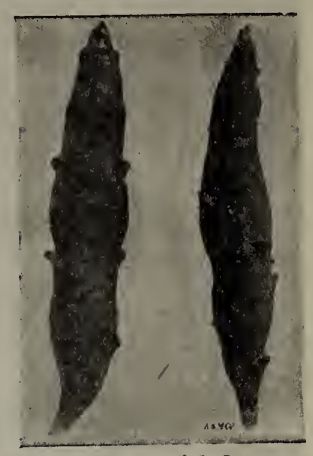

Jerusalem Artichokes.

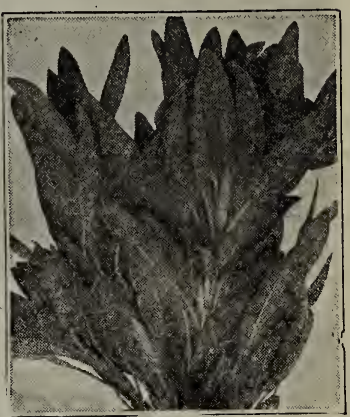

Sage.

\section{MINT ROOTS}

The true old-fashioned mint for seasoning; easy to grow and gives results the first season. Dozen, 15c; clump of roots, $30 \mathrm{c}$, postpaid.

\section{CHIVES (Schnittlauch)}

Although of the vegetable family it can also be used as a border plant for the flowers. For flavoring soups, cottage cheese, etc. When using for flavoring the tall slender leaves or tops are clipped close to the ground and chopped up fine, the same as parsley. After cutting, the tops sprout again for future use; 8 or 10 cuttings may be obtained in one season. Per bunch, large, 30c, prepaid.

SAGE

One-year clumps. Each, 30c, postpaid. TARRAGON

Highly reeommended for Tarragon vinegar. Each, 15c, postpaid.

\section{Vegetable Plant Collection 60c Postpaid}

We are offering you here a fine collection of good strong plants, a dandy assortment for an average garden. Extra care is given this collection, both as to the grade and packing, so that they will carry well by mail.
1 dozen Early Cabbage Plants.
1 dozen Late Cabbage Plants.
$1 / 2$ dozen Large Green Pepper Plants.
1 dozen Snowball Cauliflower Plants.
$1 / 2$ dozen Large Tomato Plants.

\title{
Our Easy to Grow Flower Collection
}

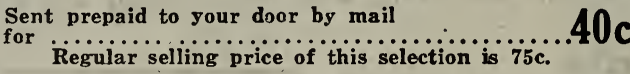

1 Pkt. Grandiflora Sweet Peas.

1 Pkt. Large Flowering Mixed Petunia

1 Pkt. Dwarf Mixed Nasturtiums.
1 Pkt. Grandiflora Mixed Salpiglossis.

1 Pkt. Cosmos.

1 Pkt. Mixed Zinnias.
1 Pkt. Dwarf French Marigold.

1 Pkt. Large Flowering Drummondi Phlox. 1 Pkt. Morning Glory, Mixed.

\section{Flowering Annuals Collection}

Alyssum, Little Gem Balsam, Defiance Mixed Calendula, Iremon Queen Calliopsis, Drummondi Centaurea, Cyanus, Double Mixed Clarkia, Finest Mixed

\section{Pkt. Each}

Cosmos, Early Flowering Mixed

Dianthus, Fordhook Favorite

Eschscholtzia, Mixed

Marigold, Tall Double Mixed

Marvel of Peru, Mixed

Nasturtium, Dwarf Our special price

separately this....................
Phlox

Poppy

Mourning Bride

Sunflower, Double Chrysanthemum, Flowered Zinnia, Giant Mammoth, Mixed

Strawflower 


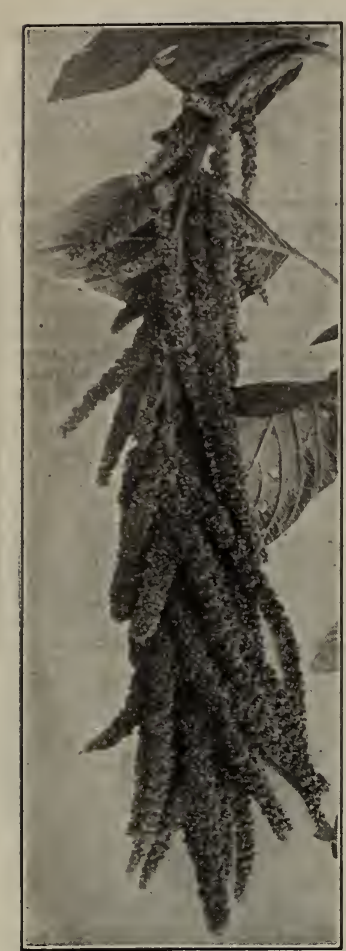

Amaranthus Caudatus.

\section{ASTERS}

The asters are now among the most interesting, beautiful and satisfactory of flowers: late years have added charming new colors and gigantic size to the kinds now being grown in this country. They thrive and flower throughout the entire Summer and there is hardly a prettier sight than a bed of asters in full bloom. They will do well in a partly shaded position where their bloscom last longer and attain a soms last longer and attain a deeper tint than in full sunshine. The aster is of easy culture and when started from seed should be sown in March or April
in the hotbed, greenhouse, or in boxes, and when the plants have three or four leaves transplant to the open, 18 inches apart each way. For aster plants, see page 66 .

\section{IMPROVED CREGO ASTERS}

This class of asters are so unique that we feel they should have a section all to themselves. Of free, sturdy growth, attaining a height of 2 to $21 / 2$ feet. The foliage is a glossy green, the branches bearing literally in masses the most graceful fluffy flowers, rarely less than four inches across, as beautiful as the most exquisite Chrysanthemum, keeping in mod other aster of this type. Blooms August to late frosts.

late frosts.

1009-Improved Crego Pink,

1010-Improved Crego Lavender.

1011-Improved Crego Crimson.

1012-Improved Crego Purple.

1013-Improved Crego Blue.

1014-Improved Crego Violet.

1016-Improved Crego Mixed.

Any of the above. Pkt., 10c; 3 pkts., 25c; $1 / 4$ oz., 25c; oz., 70c.

QUEEN OF THE MARKET ASTER

One of the finest and earliest blooming varieties. Of branching habit, 18 inches high. 1017-Mixed Colors. Pkt., 10c; 1/4 oz., 20c ; oz., 60c.

\section{FLOWER SEEDS}

\section{OUR FLOWER SEEDS ARE FRESH EACH YEAR}

There are no more satisfactory flowers than those grown from seed, especially the easily grown and expensive than a paper of seed which will furnish a large number of plants with usually enough for one

Some flowers like dahlias, etc., wilt or fade soon after they are cut. Ordinary precaution is daily change of water. The best treatment for these is to pick them at the coolest hour, either late at night or early

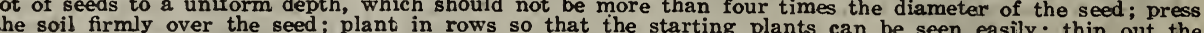
oung plants to prevent crowding and keep entirely free from weeds.

Plants are usually divided into three classes, annuals, biennials, and perennials. Annuals are plants which normally live but a single season. Biennials are plants living two years; particularly those which

ABRONIA. See Sand Verbena.

\section{ACROCLINIUM - Everlasting} A half hardy annual, producing white and rose

\section{ADONIS - Pheasant's Eye}

Flos Adonis. Feathery foliage. Hardy annual. Blood Red. Pkt., 5c; oz, 20c.

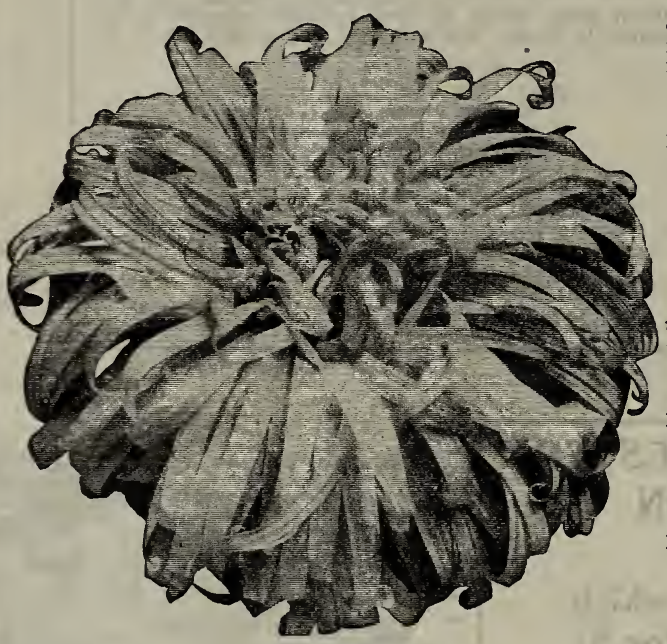

Improved Crego Aster.

\section{GIANT COMET ASTER}

Forms flowers of extraordinary size and beauty. A favorite European variety.

1018-Mixed Colors. Pkt., 10c; $1 / 4$ oz., 20c : oz., 60c.

\section{AMERICAN BRANCHING-SEMPLE'S ASTER}

The plant grows $11 / 2$ feet high. The blossoms, which are large and full petaled, are borne on long stems or branches.

1019-Mixed Colors. Pkt., 10c; 1/4 oz., 25c : oz., 75c.

\section{OSTRICH FEATHER ASTER}

The flowers of this class resemble the Japanese Chrysanthemums, with long, curved, fringe-like petals, giving a feathery appearance; of immense size. $21 / 2$ feet.

1020-Finest Mixed. Pkt., 10c; $1 / 2$ oz., 30c; oz., 50c.

\section{BALSAM - Lady Slipper}

Sometimes called "Touch-Me-Not." The colors range from white to dark purple, sometimes spotted or striped. Tender annual. 1021-Dwarf Mixed-Double. Stalks 1 foot high. Pkt., 5c; oz., 50c.

1022-Camellia Flowered Mixed. Largest double variety. Pkt., 5c; oz., 75c

\section{AGERATUM - Floss Flower}

Very attractive dwarf border flower. Free flow-

002-Dwarf Blue. Pkt., 5c; oz., 40c.

003-Mixed Colors. Pkt., 5c; oz., 25c.

AGROSTEMMA. See Rose of Heaven.

\section{ALYSSUM}

These are without doubt one of the easiest flowers grown, for borders, baskets, pots, rockwork and for cutting. In borders, sow thickly, so as to form

004-Sweet Alyssum-Common. Pure white flow. ers of a delicate fragrance. Pkt., 5c; oz, 30c.

05-Little Gem or Carpet of Snow. One of the quickest growing border plants. Pkt., 5c; oz.,

\section{AMARANTHUS, Sweet Scented}

Plants are hardy annuals and are grown for 1006-Tricolor (Joseph's Coat). Grows from 3 to 5 feet. Leaves variegated; flowers crimson. Pkt., 10c; oz., 70c.

7-Caudatus (Love-Lies-Bleeding). Long drooping crimson flower spikes with yellowish green

\section{ANCHUSA, Italica}

8-Dropmore Variety. Hardy perennial, growing about 5 feet; flowers are a clear, bright blue. kt., $10 \mathrm{c} ; \mathrm{oz}$, $\$ 2.50$.

ANTIRRHINUM. See Snapdragon. AQUILEGIA. See Columbine.

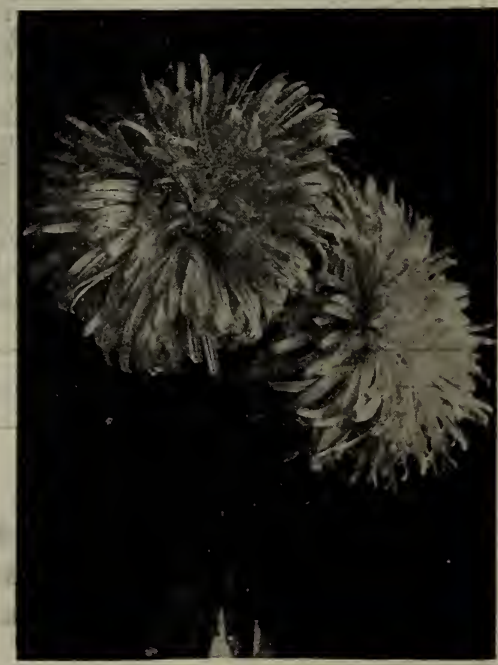

Comet Asters. 
BABY'S BREATH - Gypsophila

Small fragrant flowers, borne on long feathery stems. No flower adds more of light and grace to a bouquet than this, and when once grown will be found indispensable. 1023 -Elegans Annual. The plants are covered with pure white flowers. Pkt., 5c; oz., 30c.

1024-Elegans Rusea. A beautiful soft pink. Pkt., 10c; oz., 35c.

1025-Paniculata (Perennial): Double white, especially feathery and delicate. Pkt., $20 \mathrm{c} ; 1 / 40 z ., 50 \mathrm{c}$.

BACHELOR BUTTON. See Centaurea Cyanus.

\section{BALLOON VINE}

(Love-in-a-Puff)

Hardy annual growing $10 \mathrm{ft}$. in height. Foliage light

green. Plt., 5c; oz., 25c.

\section{BLACK-EYED SUSAN}

Hardy annual climber with flowers of buff, orange or

1027-Finest Mixed. Pkt., 10c; oz., 75c. BRACHYCOME. See Daisy, Swan River.

\section{BROWALLIA}

Blooms profusely. Excellent plant for bedding or porch boxes. Flowers are bright

\section{CALIFORNIA POPPY}

Cheerful blooms and finely cut foliage. Sow where plants are to remain. Hardy annual, grows one to one and one-half feet high.

1029-Thorburni. Coppery orange. Pkt., 10c; oz., 50c. 1030 -Golden West. Bright yellow, orange base. Pkt. 1030-Golden

1031-Californica. Rich yellow. Pkt., 10c; oz., 50c. 1032-Carmine King. Carmine-rose. Pkt., 10c; oz., 50c. 1033-Mixed Hybrids. Handsome colors. Pkt., 5c; oz., 50c.

\section{CALENDULA - Pot Marigold}

Large double flowers blooming all Summer, closing somewhat at night. Flowers grow $11 /$ to 2 feet high. In the past five years this has become very popular because it is so easy to grow, a constant bloomer, and a very desirable and decorative house flower.

1034-Double Orange King. Large, rich deep orange. Pkt., 10c; oz., 25c.

1035-Double Lemon Queen. Large lemon or sulphur. Pkt., 10c; oz., 25c.

1036-Double Mixed. Mixture of several shades of orange, yellow, and primrose. Pkt., 5c; oz., 20c.

\section{CALLIOPSIS}

One of the easiest growing annuals. Very showy and excellent for cut flowers. Flowers grow 12 to 15 inches exceller

1037-Tall Finest Mixed. Contains yellow, orange, brown, etc. Pkt., 10c; $1 / 2$ oz., 20c.

\section{CANARY BIRD VINE}

Finely cut leaves and bears a profusion of beautiful golden yellow, fragrant flowens. Tall annual climber, growing $10 \mathrm{ft}$. Easily grown.

1038-Best quality. Pkt., 10c; oz., 40c.

\section{CANDYTUFT}

Requires little care: blooms all Summer. Sow in early Spring and in August. 12 inches high. Easy to grow. 1039-Empress. Large, white trusses of branching habit very free bloomer. Recommended for bedding and cut flowers. Pkt., 5e; oz., 50c.

1040-Mixed. Áll colors. Pkt., 5c; oz., 25c.

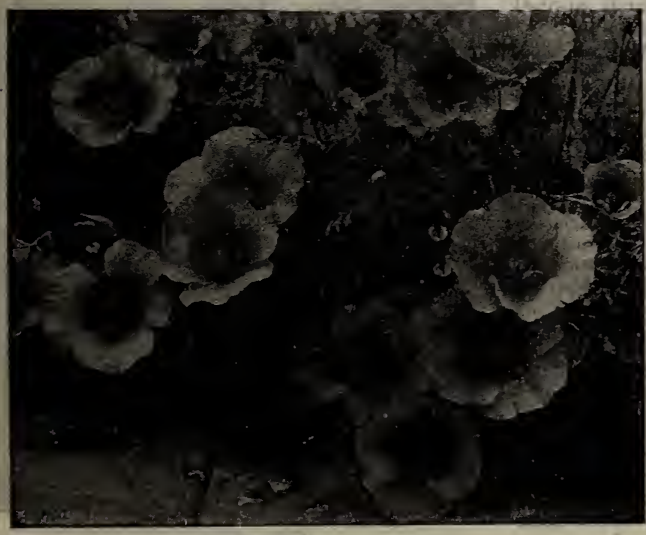

California Poppies.

\section{CANNA}

\section{(Indian Shot)}

Very showy plant with massive foliage and spikes of brilliant flowers. Seed should be soaked in warm water 24 hours before sowing. Height, three feet. 1041-Finest Mixed. All colors. Pkt. $10 \mathrm{c}$; oz., 60c.

\section{CANTERBURY BELLS (Campanula)}

Bears a great profusion of attractive, bell-shaped flowers. Hardy perennial, grows from two to four feet. 1042-Single Mixed. Pkt., 10c; oz., 50c. 1043-Double Mixed. Plt., 10c; oz., $\$ 1.00$.

\section{CASTOR OIL BEAN}

(Ricinus)

A flowering tropical appearing plant, growing to a height of 12 to 14 feet. Leaves grow to an enormous size. Used for ornamental purposes only. 1044-Zanzibarensis. Large variety. Pkt., 5c; oz., 20c.

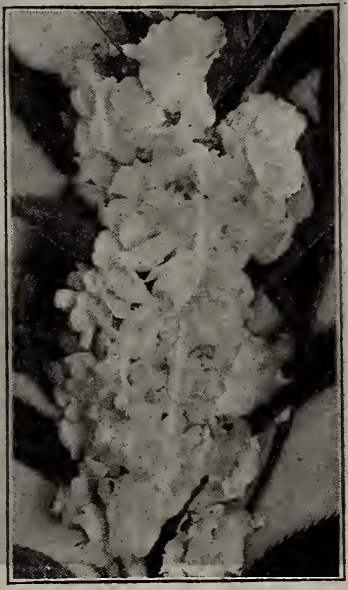

Balsam.

\section{CARDINAL CLIMBER}

An annual climber and of rapid Anth attaining a height of 20 feet. Bears many small scarlet flowers. 1050. Pkt., 15c; $1 / 4$ oz., 25c.

\section{CATCHFLY}

Forms compact round bushes; produces dense umbels of red flowers: 12 inches.

1051. Pkt., 5c.

\section{CENTAUREA}

The popular Cornflower is also known as "Blue Bottle." "Ragged Sailor," "Kaiserblume," and "Bachelor Button." These are bright flowered plants of the hardiest nature and simplest culture and yet the most attractive and graceful of all old-fashioned flowers.

\section{CENTAUREA CYANUS}

Bachelor Button, Corn Flower, Etc. 1052-Cyanus. Double, deep purple. Pkt., 10c: oz., 40c.

1053-Cyanus. Double, large blue. Pkt. $10 \mathrm{c}$ : oz., $40 \mathrm{c}$

1054-Cyanus. Mixed, blue, purple, white, pink, etc. Pkt., 5c; oz., 25c

CENTAUREA IMPERIALIS Sweet Sultin

1055-Imperialis. Yellow. Pkt., 5c; oz., 30c. 1056-Imperialis. Mixed. Pkt., 5c; oz., $50 \mathrm{c}$.

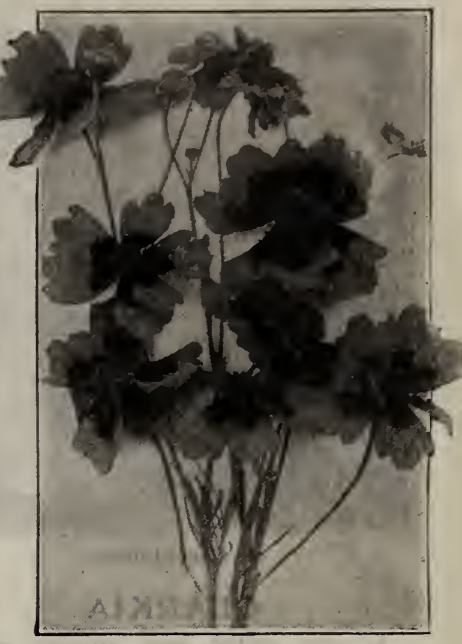

Calliopsis.

CARNATION

Are an extra vigorous race, especially adaptAor outdoor culture. They are very neat in abit and are remarkable for their rich prosion of flowers. Can be sown in early Spring oors and transplant to the open.

\section{MARGUERITE}

One of the earliest to bloom. Flowers fra. ant, deeply fringed, suited for outdoor

CHABAblooming earliest dwarf French variety. lowers in six months, large fine blooms.

-Finest Double Mixed. Pkt., 15c; 1/4 oz.,

\section{GIANT GRENADIN}

This is an extra fine double variety, far Pkt., 15c; 1/4 oz,

le Pure White. Pkt., 10c; $1 / 4$ oz., Mixed. Pkt., 10c; 1/4 oz., $40 c$.

\section{CHINESE}

\section{WOOLFLOWER}

A unique free-flowering annual whose massive globular crimson-scarlet heads resemble tufts of brilliantly colored wool. Its ease of culture and freedom of bloom throughout the Summer recommends it for general planting. 1057 - Finest quality. Pkt., $15 \mathrm{c} ; 1 / 4 \mathrm{oz}$., 50c.

\section{COCKSCOMB - Celosia} A showy annual. Anyone who grows this flower is charmed by its beauty and fantasy of form. They thrive best in a rich, warm, soil with plenty of sunshine. The heads will keep for weeks when cut and put into water.

1058-Plumosa. Dwarf. The heads of this variety are very feathery and graceful, pyramidal in shape. Pkt., $10 \mathrm{c} ; 1 / 2$, oz., 50c.

1059-Cristata. Tall. This variety has stiff, formal comb shaped heads : brilliant colors. Pkt., 10c; 1/2 0z, 50c. 1060 -Plumoss and Cristata, Mixed. Pkt., 10c ; 1/2 oz., 50c.

\section{CHRYSANTHEMUM}

Do not confuse these annuals with the winter-flowering sorts of the florists. They bloom profusely from early Summer until frost, and when grown in large beds or masses, their bright colors make a splendid show. All are fine for cut flowers. Height, 1 to $11 / 2$ feet. 1061-Finest Single Mixed (Painted Daisy). Pkt., 5c: oz. 40c (Painted 1062-Finest Double Mixed (Coronarium). Pkt., 5c; oz., 40c. 1063 -Paris Daisy (Frutescens). Pkt.,
$10 \mathrm{c}$; oz., 75e. 


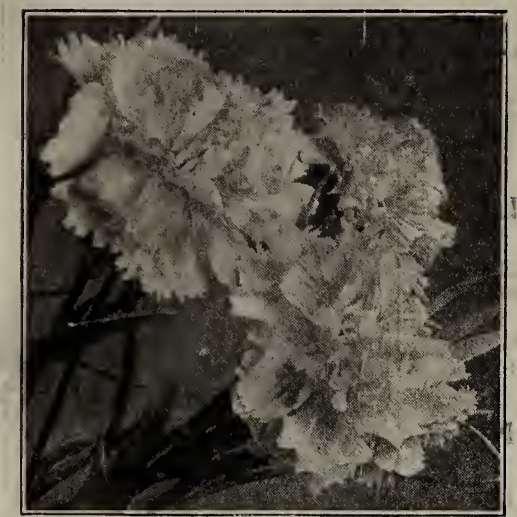

Carnations.

\section{CLARKIA}

A very pretty easy growing annual. Blooms early and freely, flowers in spikes of bright colors. Height, 2 feet. 1064--Double Mixed. Pkt., 5c; oz., 50c.

\section{COBAEA SCANDENS}

(Cup and Saucer Vine)

A perennial climber of rapid growth; growing 20 to 30 feet in a season. Bears large bell-shaped purple flowers. Free from insects.

1065. Pkt., 10c; 0z., 75c.

\section{COLUMBINE - Aquilegia}

Exceedingly showy, hardy plants, growing from 1 to $2 \frac{1}{2}$ feet high; do best in shady, moist places.

1066- Single Mixed. Pkt., 5c; oz., 75c.

1067-Double Mixed. Pkt., 10c; oz., \$1.00.

1068-Rocky Mountain. Very beautiful perennial native of Colorado. Color ranges from light to dark blue; centers cream from light to da

We can supply roots if desired. See Shrubs.

\section{COLLINSIA}

A free-flowering and easily-grown annual, reaching a height of 1 to 2 feet. Flowers white, crimson, purple, etc.
California wild flower.

1069-Best Mixed. Pkt., 5c; oz., 30c.

\section{COSMOS}

A strong, tall-growing annual, with bold flowers of exquisite daintiness and airiness, flowers of exquisite daintiness and airiness, heightened in effect by their foliage-setting of feathery green. It is most effective when
planted in broad masses or along backplanted in broad masses or along background border against evergreens or fence

1070-Early Flowering Mammoth Mixed. Earliest of all. This new strain will produce flowers in July from seed sown in duce flowers in July from seed sown in the open ground in May.

1071-Extra Early Flowering, Pink. Pkt. 5c; oz., 35c.

\section{EARLY FLOWERING DOUBLE CRESTED}

We now have an extra early flowering strain of the double crested type which we recommend very highly for their grace and beauty. They come into flower fully as early as the extra early singles and bloom freely until frost. The flowers are large, ranging from 3 to 4 inches across, the double center standing up like a cushion. Finest mixed.

1072-Mixed. Pkt., 10c; 1/4 oz., 50c.

\section{CYPRESS VINE}

A tender annual climber with finely cut leaves and small star-shaped scarlet flowers. 1074-Mixed. Pkt., 5c; oz., 35c.

\section{CUT FLOWERS}

This mixture contains all the main varieties of flowers suited for cut flowers and the ones that are easily grown.

1073-Best Mixture. Liberal Pkt., 10c; oz. 25c.

\section{DAHLIA}

Dahlias are of easy cultivation : gnowing freely in most any soil from seed in the Spring. Although perennial they er the first season if sown early. 1076-Single Mixed. Pkt., 10c; oz., \$1.25.

\section{DUSTY MILLER}

1082. An excellent plant for border, having graceful, arching silver-gray leaves Plants grow from 1 to $1 \frac{1}{2}$ feet tall. Pkt. $10 \mathrm{c} ; 0 \mathrm{z}, 40 \mathrm{c}$.

DIANTHUS, See Pinks.

DIGITALIS. See Foxglove.

DoLICHOS. See Hyacinth Bean.

DELPHINIUM. See Larkspur.

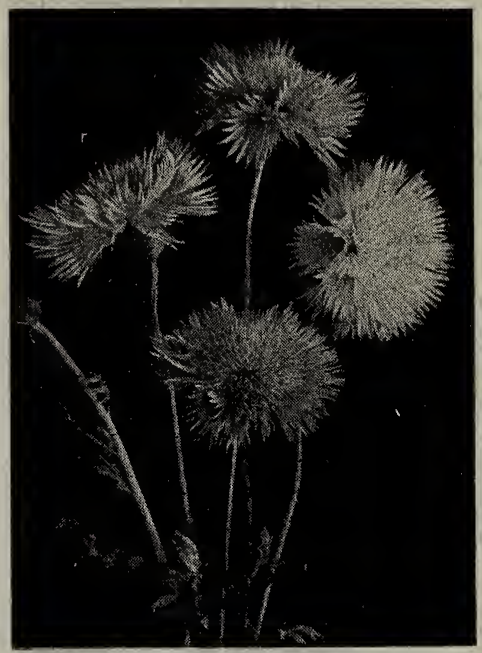

Centaurea-Sweet Sultan.

\section{DAISIES}

1077-Double English Daisy. Seed sown in early Spring will bloom the first Summer, and continue for years if given a slight proand continue for Winter. Should be sown in partial shade. H. P. 3 to 6 inches. Pkt., 10c. 1078-African Daisy (Dimorphotheca). Rare and very showy annuals, from South Africa; having daisy-like flowers of a glossy salmonorange shade with black central ring. A lovely color when flower is open in the sun. Height, one foot. Pkt., 10c: oz., \$1.25.

1079-Blue-Eyed African Daisy. Hardy annual easily grown from seed. The daisy-like flowers are silvery-white with a blue eye surder part of petals is lilac-blue. Pkt., 10c.

1080-Shasta Daisy. A hardy perennial; sometimes flower with large white petals and dark centers, measuring 3 to 4 inches across. Pkt., $10 \mathrm{c} ;$ oz., $\$ 1.00$.

1081-Swan River Daisy (Brachycome). Freeflowering dwarf annuals covered during the greater part of Summer with a profusion of pretty blue and white flowers. Suitable for edgings ; 9 inches. Pkt., 10c; oz., $\$ 1.00$.

eschscholtzIA. See California Poppy. EVERLASTING FLOWERS

See Acroclinium, Globe Amaranth, Statice and Xeranthemum.

\section{EVENING PRIMROSE}

\section{(Oenothera)}

1084. A free-flowering annual producing an abundance of large, single flowers which open in the evening. Pkt., 10c
EVERLASTING SWEET PEAS

(Lathyrus)

1083. A hardy, perennial climber, growing 10 feet high. Flowers resemble Sweet Peas, but are borne on racemes with eight to ten flowers to the stem. Pkt., 15c.

\section{FEVERFEW - Matricaria}

1085. Pretty and neat. Small, double white flower, being hardy annual, growing 2 feet high. Pkt., 5c; oz., 50c.

FIRK PLANT. See Burning Bush.

FLOWERING SAGE. See Salvia.

FORGET-ME-NOT - Myosotis

These dainty little flowers love cool, moist soils, and like pansies, bloom most freely in Fall and early Spring. They make beautiful close borders or edgings.

1086-Mixed. Pkt., 10c; 3 pkts., 25c.

\section{FOUR O'CLOCK \\ (Marvel of Peru)}

Plants are large and require plenty of space. Flowers sweet scented, funnel-shaped, bein white, red, yellow or striped. Open about o'clock in the afternoon. 2 feet. 1087-Dwarf Mixed. Pkt., 5c; oz., 20c. 1088-Tall Mixed. Pkt., 5c; oz., 20c.

\section{FOXGLOVE - Digitalis}

The tall, flower-like spikes of the Foxgloves, often 2 to 3 feet., are particularly handsome when grown among shrubbery or in masses. 1089--Mixed. Pkt., 10c; oz., 35c.

\section{GAILLARDIA}

A constant bloomer from early Summer to late Fall. Flowers scarlet and orange. While it is a hardy perennial, will bloom the first year from early planting. Height, $11 / 2$ feet.

1090 Grandiflora mixed. Pkt., 5c; oz., 35c.

\section{GERANIUM}

The must popular bedding plants and for pot culture. The blooms are very brilliant and leaves are beautifully marked.

1091-Mixed. Double and single. Pkt., 20c.

\section{GLOBE AMARANTH}

Produces small, very showy, everlasting globeshaped flowers. When in full bloom should be cut and hung up to dry. Will hold their color

092-Finest Mixed. Pkt., 5c; 1/2 oz., 20c.

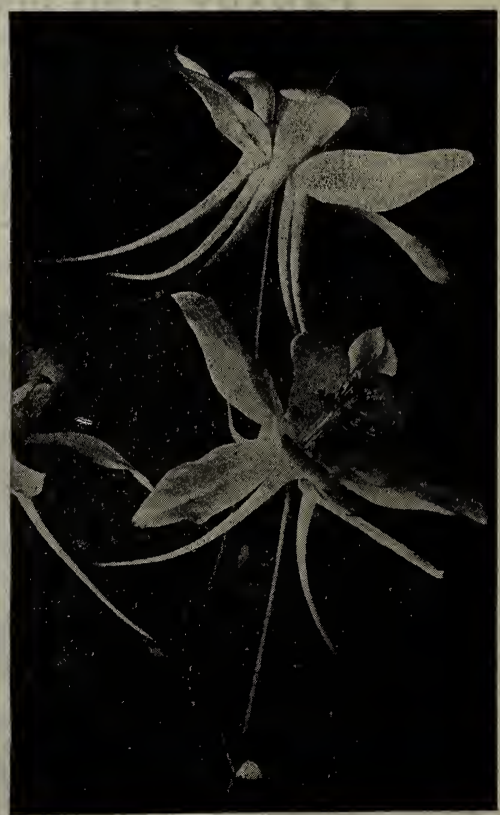

Columbine. 


\section{GODETIA - Satin Flower}

Rapid growing; large, Mallow-like flowers; very ornamental as pot plants or in mixed beds. Plants require plenty of room and thrive better in a poor soil. Two feet.

poo3-Dwarf Varieties Mixed. Pkt., 5c; 1/2 oz., $20 c$.

\section{GOURDS, ORNAMENTAL}

climber. Quick growing vines; excellent for covering arbors, walls and waste places. Gourds grow in curious shapes and are used for house ornaments.

1094-Finest Mixed Varieties. Pkt., 5c; oz., 20c.

GYPSOPHILA. See Baby Breath.

HELIANTHUS. See Sunflower.

\section{HELICHRYSUM - Giant Strawflowers}

The largest and showiest of the everlastings, are effective for winter bouquets mingled with Statice and otber dried flowers. If wanted for drying, cut with as long stems as possible when the flowers are about onethird open. Strip off all the foliage, tie in small bunches and hang heads downward in some dark dry place until cured

downward in some dark, dry place until ce.
1095 -Finest Mlixed. Pkt., 5c; $1 / 4$ oz., 20c.

\section{HELIOTROPE}

These well known greenhouse and bedding favorites are highly valued for their sweet scented flowers.

1096-Purple. Pkt., 10c; oz., \$1.50.

109 - Mixed. Pkt., 10c; oz, \$1.50.

\section{HOLLYHOCKS}

These stately, old-fashioned perennials are most striking when seen in groups or long rows against evergreen hedges, shrubbery, etc., and, in their turn form a very fine background for plants of lower growth. 1098 -Double Mixed. Plt., 10 c; oz., si.00. 1099-Single Mixed. Pkt., 5c; oz., 65 c.

\section{HYACINTH BEAN}

(Dolichos)
A fine climber with clusters of purple and white flowers.

1100-Mixed colors. Pkt., 5e; oz., 25 c.

\section{ICE PLANT}

1101. Flowers frosted or wax-like. Excel lent for hanging baskets or rockwork. Six inches. Pkt, $5 c$.

IMMORTELLES See Everlasting Flowers. IPOMOEA GRANDIFLORA See Moon Flower.

IPOMOEA PURPUREA See Morning Glor IPOMOEA QUAMOCLIT See Cspress Vine

\section{JAPANESE HOP} (Humulus)

1102 There is no hardier vine than this. Resists drought, and insects never bother it. The foliage is beautifully variegated. Pkt., 10c; oz., 75c.

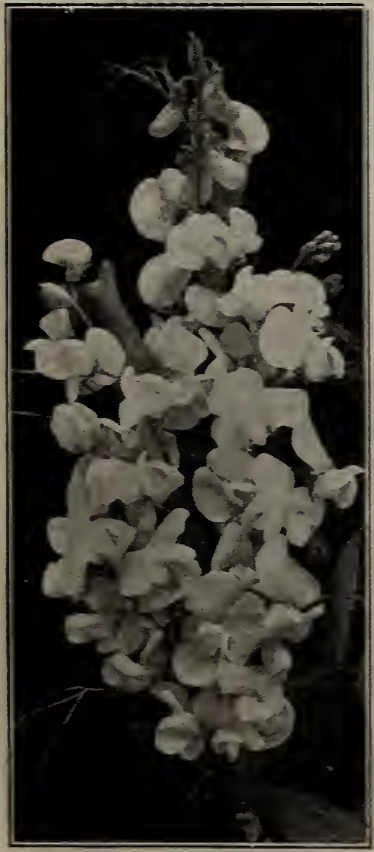

Everlasting Sweet Peas.

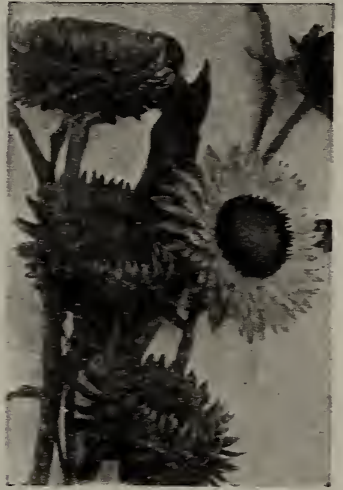

Helichrysums.

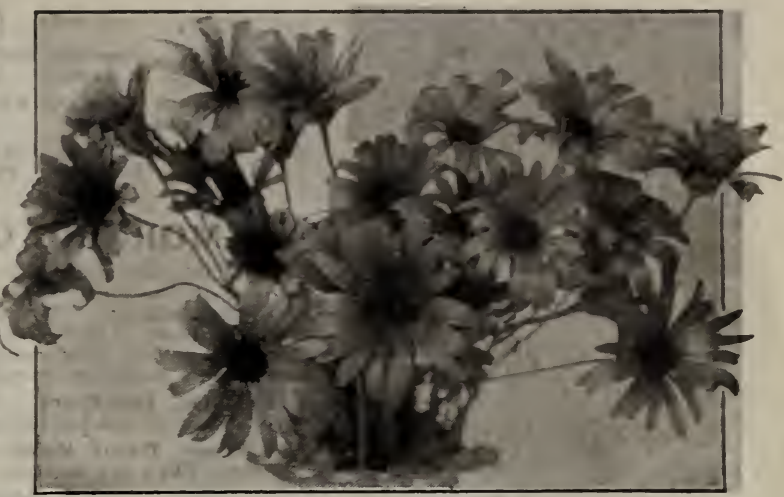

African Daisies.

\section{LARKSPUR - Delphinium}

\section{ANNUAL}

These free blooming annuals are very easily grown. Seeds planted in the open in Spring will soon produce beautiful flowers, borne on long spikes. Very effective in beds or masses. Grows two feet high.

1107 -Double Mixed. Tall. Pkt., 5c; oz. 40 e.

$1108-B l u e$. Tall. Pkt., 10c; oz, 40c.

1109-White. Tall. Pkt., 10c; 0z, $40 \mathrm{c}$

1110-Pink. Tall. Pkt, 10c; oz., $40 \mathrm{c}$. PERENIIAL

Hybrid Large Flowering. Single, semi-double and double in attractive shades of lavender, blue, and purple. The plants are tall growing and are most desirable as a background for lower growing flowers or for planting in elumps in the open border.

1111-Mired. Pkt., 10c; 1/2 0z, $\$ 1.00$.

\section{LOBELIA}

Charming little plants that bloom very quickly from seed, and continue gay with flowers all through the season.

1113-Royal Purple. Deep blue, with distinct white eye. Plkt. $10 \mathrm{c} ; \mathrm{oz}$. isc.

1114-Tall Mixed. Pkt, 10c; oz., 65c.

LOVE-LIES-BLEEDING. See Amaranthus.

\section{MARIGOLD}

Old-fashioned annuals, rich and showy, blooming continually all Summar; excellent for bouquets and a beautiful garden plant. Tall African varieties are best for garden and cutting, while French and other sorts are especially adapted for edgings.

\section{GIANT AFRICAN, DOLBLE}

corn-like ornamental grass with broad, ored seeds used for beads. Valuable for winter bouquets with everlastings. 1103. Pkt., 5c; 0z., $15 \mathrm{c}$. JOSEPH'S COAT See Amaranthus.

\section{KOCHIA}

(Summer Cypress)

This splendid ornamental annual is sometimes called Burning Bush. The plants form a dense oral bush, 2 to 4 feet high. Light green foliage, changing to carmine as Summer advances. 1104. Pht., 5c; 0z., 25c.

\section{KUDZU VINE}

(Jack-and-the-Beanstalk Vine)

Hardy perennial climber. Grows 8 to 10 feet the first season from seed, each year getting larger. Forms a dense shade; unequalled for porches, arbors, etc.

1105. Pkt., 10c; 3 for $25 \mathrm{c}$.

\section{LACE FLOWER}

Hardy annual Grows about 2 feet in beight, with lovely blue flowers. Make beautiful and lasting cut flowers. 1106. Pkt., 15c.

\section{LANTANA}

A rapid growing plant. The flowers borne in Verbens-like heads, embracing every shade of pink, purple, orange, and

white. Height, about 2 feet.
1112. Pkt., 10e; oz., 50c.
Three feet tall.

1115-Finest Mixed. Pkt., 5c; $1 / 4$ oz., $45 c$.

1116 -Orange Prince. Plkt., 5c; $1 / 4$ oz., $45 c$.

Eight inches tall.

FRENCH, DWARF DOUBLE

1117 -Finest Mixed. Pkt., 5c; $1 / 4$ oz., $45 \mathrm{c}$.

$$
\begin{gathered}
\text { MARVEL OF PERU. See Four O'Clocks. } \\
\text { MATRICARIA. See Feverfew. }
\end{gathered}
$$

Beautiful, rapid climber. Blooms profusely until late in season.

1118. Pkt., 20c.

\section{MIGNONETTE} in all gardens. Cultivated for its fragrant flowers, which come quickly. Set in compact spikes. Sow in early Spring.

1119-Reseds Odorata Grandiflora. This is the sweet scented border variety. Plst, 5c; oz., $25 \mathrm{c}$.

1120-Improved Hachet. Flowers are very large, of reddish green color, very fragrant. Plkt., 5c; oz., 50c.

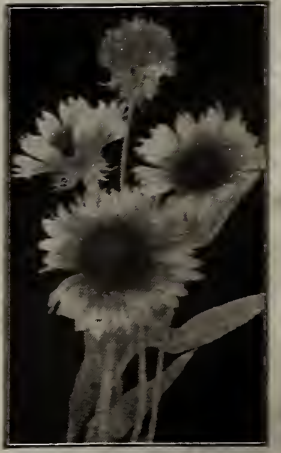

Gaillardias.

\section{MAURANDIA} the Autumn; will flower the first

A well-known favorite annua 


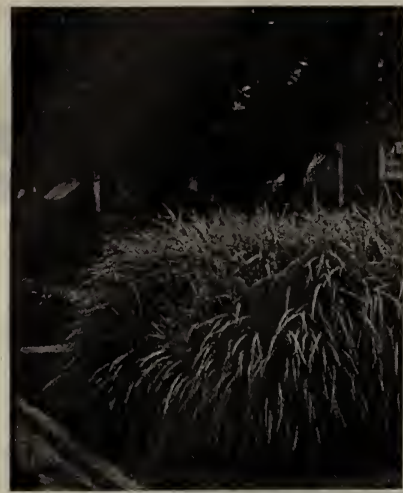

Ornamental Grasses.

1126-Blue Rochester. Heavenly blue. Pkt., 15c. 1127-Clark's Blue. Large light blue flowers.

Pkt.o, 15c. dreds of various colored flowers. Vines are very vigorous, growing to a height of 10 to very vigorous, growing to a
12 feet. Pkt., 10c; oz., 25c.

\section{MOURNING BRIDE}

\section{(Scabiosa)}

Well established garden favorites. They grow about 2 feet high and commence to bloom early in July, continuing until frost. The flowers are borne on long stems and last a long time when cut. Fine for beds or borders, growing two feet in height.

1129 -Tall Double Mixed. Pkt., 5c; oz., 70c. 1130-Dwarf Double Mixed. Pkt., 5c; oz., 70c. MYOSOTIS. See Forget-Me-Not.

\section{NASTURTIUMS}

If you have space for them, you cannot have too many Nasturtums. Easy to grow in most any soil. Plant the seed anywhere. The tall kinds are especially suitable for covering fences, rockThe tall kinds are especially suitable for covecially adapted for eries, trellises and the dwarf varieties especially adapted for borders. All Nasturtiums are very showy with their brilliant $5 \mathrm{c} ; 0 \mathrm{z} ., 15 \mathrm{c}$; $1 / 4 \mathrm{lb}$., $45 \mathrm{c}$; any six $5 \mathrm{c}$ packets, $25 \mathrm{c}$, postpaid.

TALL or CLIMBING

$$
\text { VARIETIES }
$$

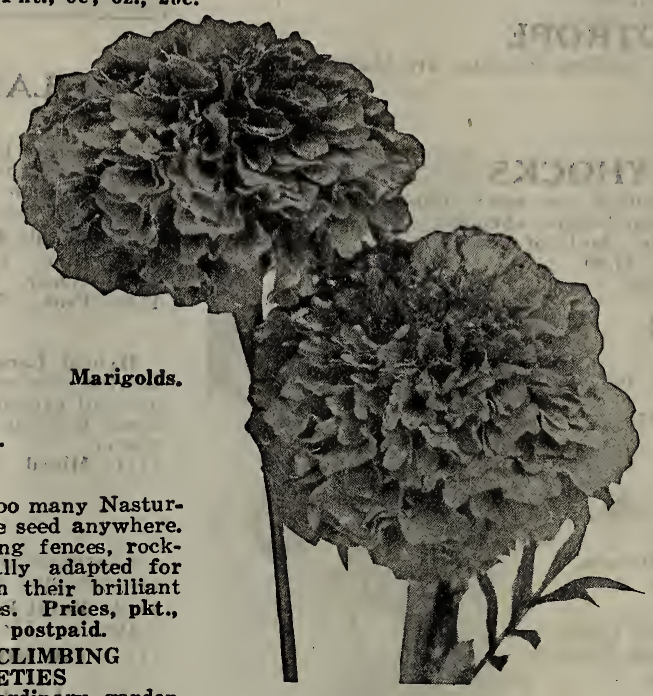

Besides their-ordinary garden use for trailing over fences, trellis, stone wal

can be used for hanging baskets and for pot plants for winter flowering as screens.

1131--King Theodore. Dark red.

1132-Heinemann. Chocolate.

1133-Jupiter. Rich yellow large flowers.

1134--Pearl. Cream white.

1135-Von Moltke. Bluish rose.

1136-Variegated Leaved. Every leaf is variegated with yellow, white and green.

1137-Mixed. Contains all tall varieties. Any of the above. Pkt., $5 c$; oz., $15 \mathrm{c} ; 1 / 4 \mathrm{lb}$., $45 \mathrm{c}$.

\section{DWARF OR TOM THUMB VARIETIES}

These have a neat, compact habit and attractive foliage, are not disturbed by insects, bloom in two months from sowing.

1138-King Theodore. Dark red flower and dark leaf.

1139-Lady. Bird. Rich yellow spotted scarlet.

1140-Golden King. Golden yellow, dark leaved.

1141--Pearl. Cream white.

1142- Empress of India. Dark scarlet flowers.

1143-Mixed. Contains all dwarf varieties. Any of the above Pkt., 5c; oz., $15 c$; $1 / 4$ lb., 45c.

\section{NEMESIA}

Pretty annual ; produces orchid-like flowers. 1144-Large Flowering. Pkt., 15c.

\section{NICOTIANA - Flowering Tobacco}

Species of tobacco. Valuable as decorative plants. Height, 3 feet Sweet scented flowers.

1145-Mixed. Pkt., 10c.

\section{NIGELLA - Love-in-a-Mist}

An easy to grow annual. Flowers blue and white, foliage fine moss.

Mignonette.

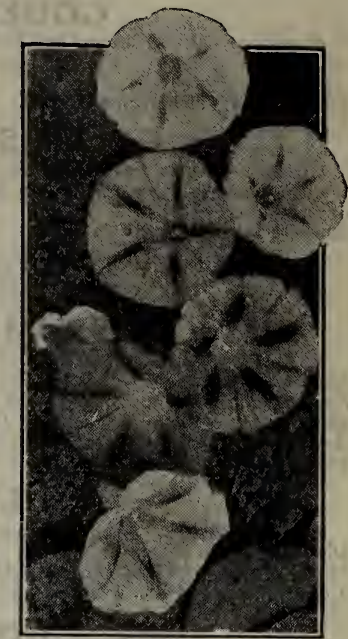

Morning Glory.

\section{MOONFLOWER}

A beautiful summer climber, grows 20 to $40 \mathrm{ft}$. high makes nice shade for porches and bears a profusion of large, trumpet-shaped flowers ; richly scented.

1123-Finest quality. Pkt. $10 \mathrm{c}$; $1 / 2$ oz., 30c.

\section{ORNAMENTAL GRASSES}

Very showy foliage; blooming during the Summer and Fall. Height, 2 feet. 1147-Mixed. Pkt., 10c.

OENOTHERA

See Evening Primrose.

\section{PASSION FLOWER}

Fast growing. Hardy perennial climber. 1152-Mixed. Pkt., 10c.

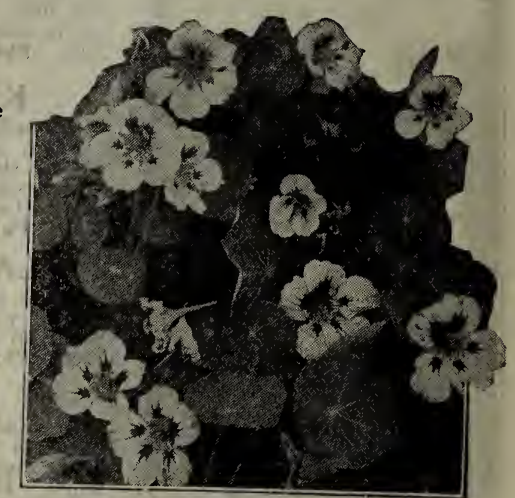

Nasturtiums. 


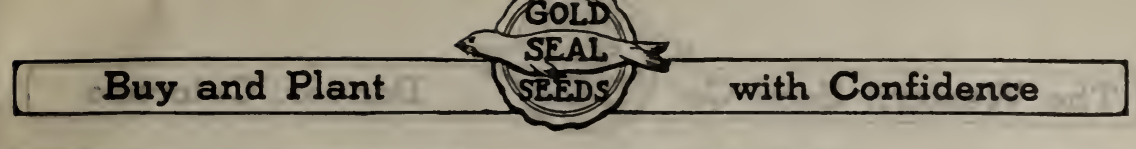

Flower Seeds

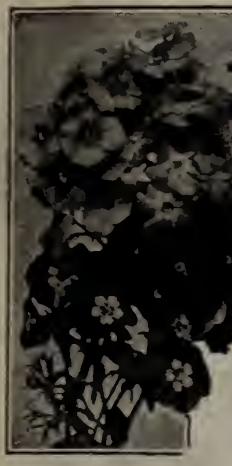

Phlox

Drummondi.

\section{PANSIES}

This flower with its alluring little faces and beautiful markings of brilliant and blending colors, if given a chance, makes one of the most popular flowers we have and it is easily grown. Best adapted to partly moist and somewhat shaded places but for large blooms, rich soil is best. Seed sown in Spring will bloom in midsummer. For early Spring flowers, sow seed in August and protect plants in cold frames or straw during Winter.

\section{BRIGHT COLORS}

A good variety of excellent colors, but flowers are only madium size 1148 -Good Colors. Pkt., 5c; 1/4 oz., 35c; oz., $\$ 1.00$.

GIANT TRIMARDEAU

This is a French variety. Flowcrs are large size, of most beautiful and varied shades, usually marked with three large blotches. We recommend this variety where a wide range of color is desired. 1149 -Mixed. Pkt., 10c; 1/4 oz., 50c; oz., $\$ 1.50$.

\section{MAMMOTH EXHIBITION}

This strain comprises a beautiful collection of colors and markings and is one of the finest mixtures both as regards size and color. 1150 -Mixed. Pkt., 20c; 1/4 oz., 80c; oz., \$3.00.

GOLD SEAL GIANTS

This superb strain selected by a leading domestic grower, is the largest and best in cultivation. Not only are the flowers of gigantic size, but for brilliancy of color and markings they are unexcelled. We especially recommend this strain for florists and those who make a specialty of growing pansy plants for commercial trade.

1151 -Mixed. Pkt., $25 \mathrm{c} ; 1 / 4$ oz., $\$ 1.50$; oz., $\$ 5.00$.

\section{PETUNIA}

There is no flower more highly prized for use in beds, massing, borders, window-boxes, baskets, and vases. Succeeds in almost any soil and produces very fragrant blooms the entire Summer. Sow thinly and do not cover seed to a depth of more than four times their size.

1153 -Petunia, Hybrida White.

$10 \mathrm{c} ; 1 / 4 \mathrm{i}$ oz., $30 \mathrm{c}$.

1154-Petunia, Hybrida Scarlet. Pkt. $10 \mathrm{c} ; 1 / 4$ oz., 30c.

1155-Petunia, Hybrida Violet. Pkt., $10 \mathrm{c} ; 1 / 4$ oz., $30 \mathrm{c}$.

1156-Petunia, Striped and Blotched. Pkt., 5c; $1 / 4$ oz., 30 c.

1157-Petunia, Hybrida. Finest mixed. Pkt., 5c; oz., 75c.

\section{GRANDIFLORA}

This is the finest Petunia grown Flowers extra large, beautifully marked, double and fringed. If you appreciate fine Petunias, try these.

1158-Double Mired. Pkt., 50c; $1 / 8$ oz., $\$ 15.00$.

1159-Giant Flufiy Ruffles, Pkt, 40 c.

11591/2-Rosy Morn. A very compact dwarf type, soft pink, especially fine for window and porch boxes. Pkt., for window and

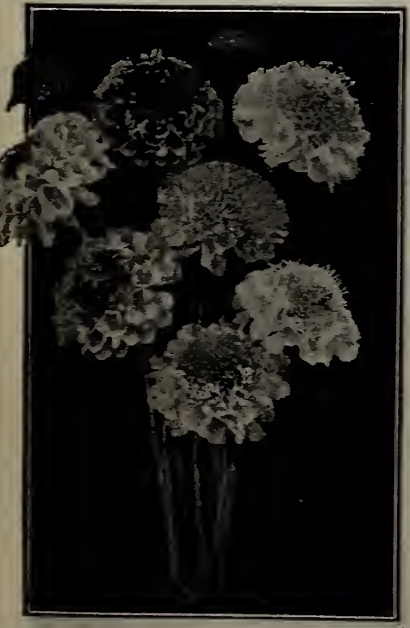

Mourning Bride-Scabiose.

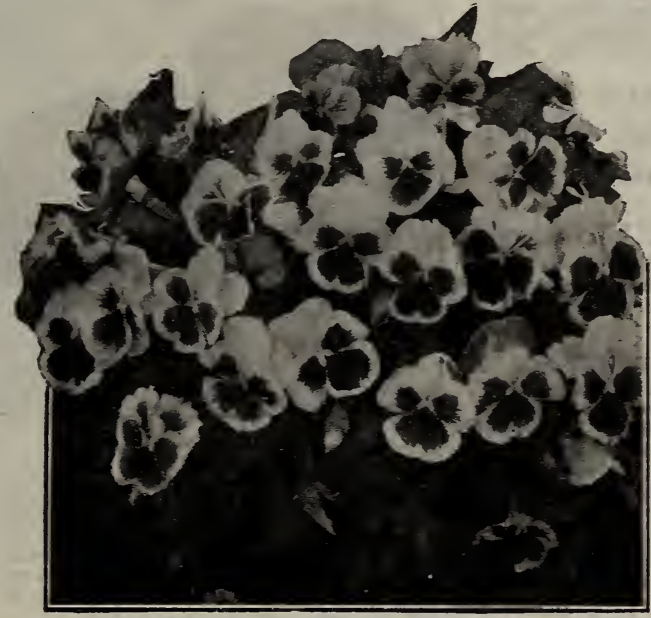

Giant Trimardean Pansies.

\section{PINKS, GARDEN - Dianthus}

This satisfactory old-fashioned flower blooms in profusion all SumTher are hardy and ow trelve to fifteen inches tall and bear marvelous brilliant and contrasting flowers, which are emphasized by stripes and dots.

116.4-Chinese or Indian Pink. Blood red, double Pkt., 5c; oz., $25 \mathrm{c}$. 1165-Chinese or Indian Pink. Extra double, mixed. Pkt., 5c; oz., 25 c.

1166--Chinese or Indian Pink. Single mixed. Pkt., 5c; oz., 25c.

\section{PORTULACA - Rose Moss}

This little annual is unexcelled for brilliancy among the flowers of low growth. Grows and blooms best in the hot sunlight, carpeting the ground with a mat of foliage, which in the afternoon is hidden with gayest of flowers. Sow seed in the open ground.

1173-Large Flowering Double Mixed. Pkt., 10c; 1/4 oz., 60c; oz. $\$ 2.00$.

1174-Large Flowering Single Mixed. Pkt., 5c; oz., 75c.

\section{PYRETHRUM}

Hardy perennial with daisy-like flowers of bright colors.

1175-Roseum (Insect Powder Plant). Single flowers of pink, rose, and white. Pkt., 10c.

1176-Golden Feather. Grows 6 inches, with rich yellow foliage. Pkt., 10c.

RICINUS. See Castor-Oil Bean.

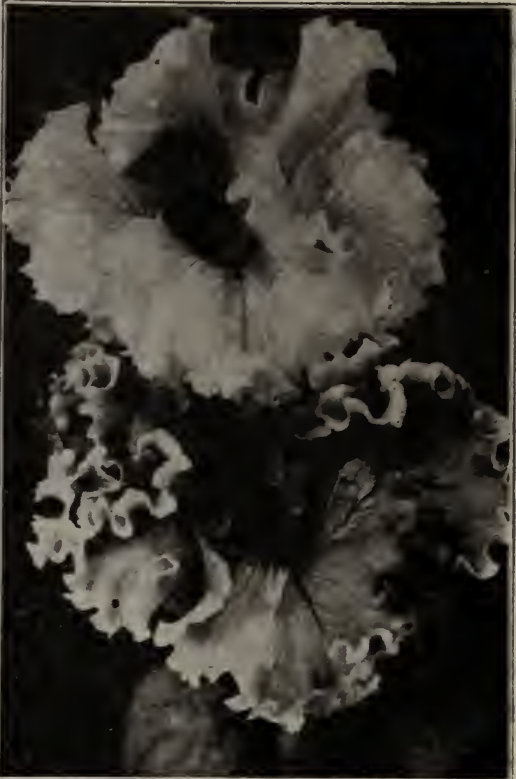

Giant Fluffy Rufiles Petunias.

PHLOX

DRUMMONDI (ANNUAL)

Being one of the prettiest annuals, hlox should occupy a prominent place every garden. Of easy cultivation, ind remarkable for profusion of bloom, continues until frost. The rich effect in beds or borders. Fine for cutting. 160 - All Varieties Drummondi Mixed. Pkt., 10c: 1/2 oz., 40c.

Fringed and Star Shaped Mixed. 10c; 1/2 oz., 40c.

Splendens. Brilliant scarlet, white

ye. Pkt., 10c; 1/2 oz., 40c.

\section{PERENNIAL PHLOX}

Individual flowers similar to the an. ual variety, but borne in clusters of 30 40 flowers on a tall stiff stem 2 to eet high.

163-Mixed. Pkt., 10c.

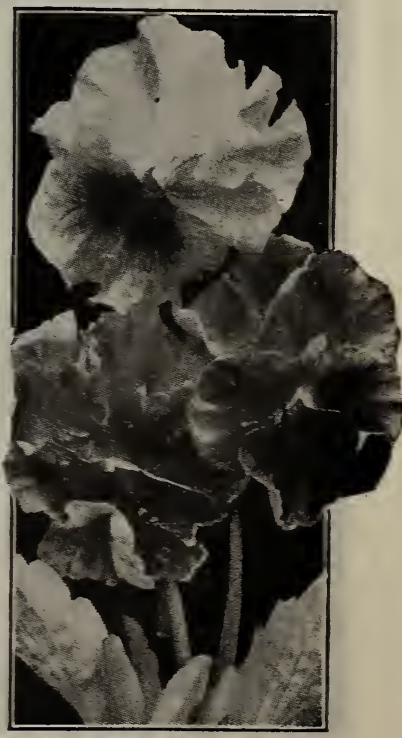

Mammoth Exhibition Pansies. 


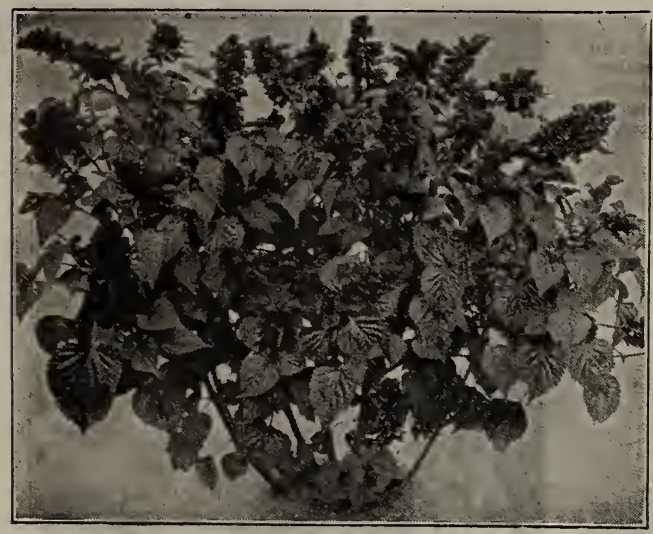

Salvia-Scarlet Sage.

\section{POPPY - Papaver}

(ANNUAL VARIETIES)

This is a quick, easily grown flower, ranging in color from pure white to darkest crimson and violet. Plant in the open and thin to 8 inches apart. They will not transplant.

1167-Flanders Field. The famous poppy of Flanders Fields. Single annual of blood red color. Pkt., 10c; oz., 30c.

1168-Shirley. Beautifully crimped petals : wonderful shades of blue, lavender, salmon, etc. Pkt., 5c;

1169-Carnation Flowered Double Mixed. Very double fringed; colors dazzling. Pkt., 5c; oz., 30c.

1170-Peony Flowered Double Mixed. Immense double, globular flowers. Pkt., 10c; oz., 30c.

\section{PERENNIAL VARIETIES}

While these are perennials, they usually bloom the first year.

1171-Oriental. Enormous flowers; deep flashing scarlet; hardy perennial, growing 3 feet in height. Pkt., 10c; 1/2 oz., 50c.

This is the new Iceland Poppy, gracefully brilliant, excellent for cutting. Plant is low and compact. 1172 -Finest Mired. Pkt., 10c; 1/2 oz., $40 \mathrm{c}$.

\section{ROSE OF HEAVEN - Agrostemma}

A hardy free blooming annual with flowers of bright rose. Two feet.

1177. Pkt., 5c; oz., 30c.

\section{SALVIA - Scarlet Sage}

A tender perennial blooming the first year from seed. Well known bedding plants with long, flaming flower spikes, displayed with striking effect against the deep green foliage. $11 / 2$ to 3 feet.

green foliage. 11/2 to 3 feet. oz., $\$ 1.50$.

1179-Bonfire. Compact bush, growing 2 feet. Pkt., 10c $1 / 4$ oz., 50c; oz., $\$ 1.50$.

1180 -Coccinea. Small scarlet flowers. Pkt., 5c; $1 / 2$ oz. $20 \mathrm{c}$.

\section{SALPIGLOSSIS - Velvet Flower}

Half hardy annual; grows 14 inches high. Flowers showy, large, funnel-shaped, mottled, veined and selfcolored. Requires rich soil.

1181-Mixed. Pkt., 10c; 1/2 oz., 50c.

\section{SCARLET FLAX - Linum}

1182-Grandiflora. A very attractive annual, growing 8 to 12 inches high. The rich, crimson flowers last but a day but they bloom continuously until frost. They like a warm sunny location. Pkt., 5c; oz., 40c.

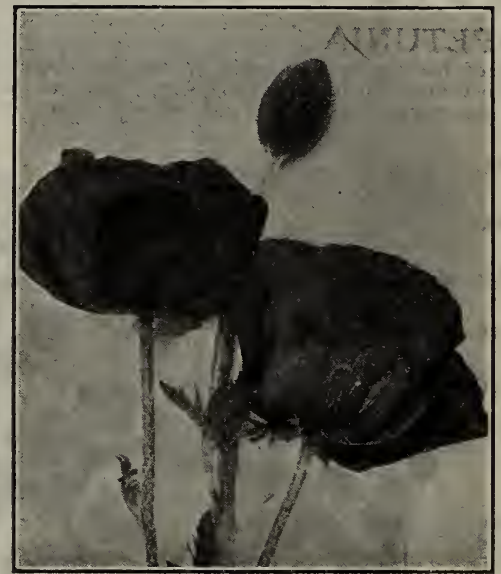

Oriental Poppies.

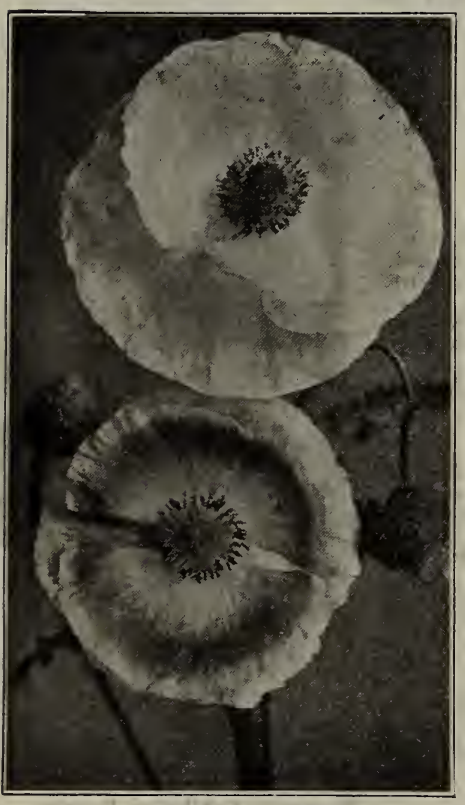

Shirley Poppies.

\section{SNAPDRAGON - Antirrhinum}

The Snapdragon is one of our finest perennials, flowering the first year from seed. Its bright-colored, curiously-formed flowers always excite interest. Height, $2 \mathrm{ft}$. 1187-Finest Tall Mixed. Pkt., 5c; oz., 75c. 1188-Finest Dwarf Mixed. Pkt., 5c; oz., 75c. 1189-White, Tall. Pkt., 5c; oz., 75c. 1190-Scarlet, Tall. Pkt., 5c; oz., 75c. 1191-Bright Rose, Tall. Pkt., 5c; oz., 75c. 1192-Golden Orange, Tall. Pkt., 5c; oz., 75c. 1193-Yellow, Tall. Pkt., 5c; oz., 75c 1194-Purple, Tall. Pkt., 5c; oz., 75c.

\section{SNOW-ON-THE-MOUNTAIN}

A very showy plant; makes a beautiful combination with other flowers.

1195. Pkt., 10c; oz., 25c.

\section{STOCKS}

Are used for bedding, borders, pot culture or bouquets. To secure early flowers, start seed in window-boxes or under glass in March or April, and transplant to the open ground in the middle of May. $11 / 2$ to 2 feet.

1197-Ten Weeks. Finest single mixed. Pkt., 5c; oz., $\$ 1.00$.

1198-Ten Weeks German. Finest double mixed, dwarf. Pkt., 10c ; oz., \$1.25.

\section{STRAWFLOWER}

See Acroclinium, Globe Amaranth, Helichrysum, Statice, Xeranthemum. Pkt. each of the above, 20c, postpaid.

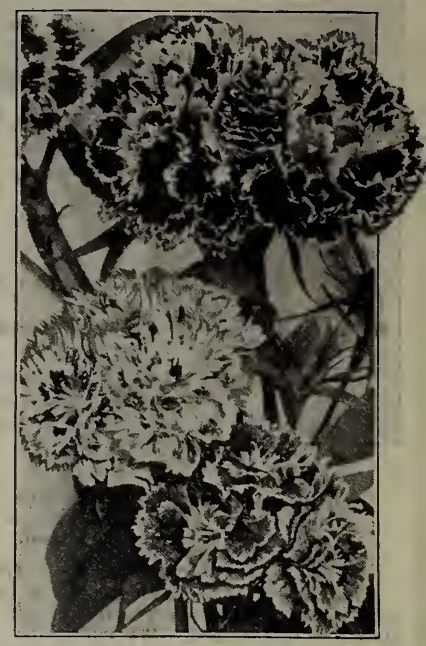

Chinese Pinks.

\section{SAND VERBENA}

\section{(Abronia)}

Very pretty, trailing plants numerous clusters of sweet scented flowers. Rosy lilac, with white eye.

1183. Pkt., 5c. SCABIOSA See Mourning Bride.

\section{SCARLET RUNNER BEAN}

Ornamental climber, with bright scarlet blooms.' Excellent for porches or trellis.

1184. Pkt., 5c; $1 / 4$ lb., 15c.

\section{SENSITIVE PLANT}

The leaves instantly fold up when touched; elegant foliage, height $11 / 2$ feet.

1185. Pkt., 10c.

\section{SMILAX}

A perennial climber with deep, glossy green leaves.

1186. Pkt., 10c.

\section{STATICE}

An easily grown everlasting annual. They prefer a sunny situation. Very satisfactory for winter bouquets after being dried. 1196 -Best Mixed. Pkt., 10c; 1/2 oz, $25 \mathrm{c}$.

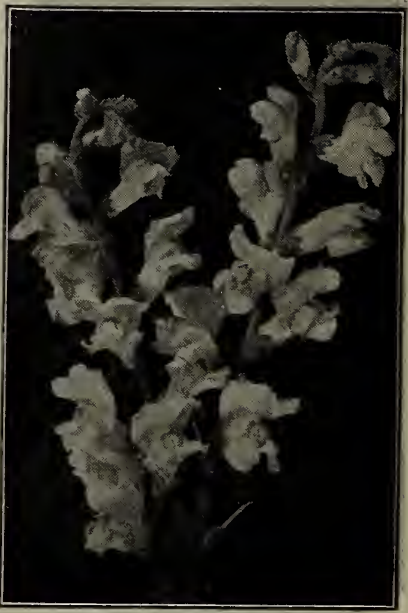

Snapdragon. 


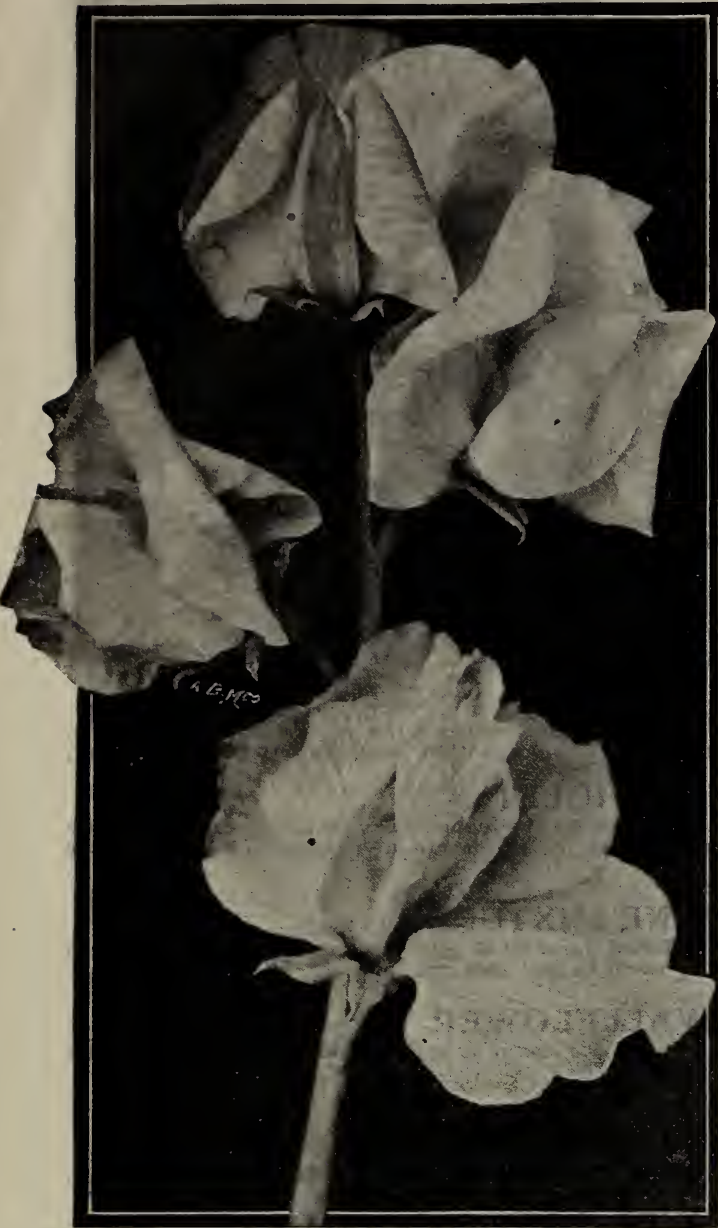

Enchantress Sweet Peas.

PURPLE

1521--Royal Purple. Large flower, color royal purple. ROSE

1522-Risobel. Large light rose.

1523-Martha Washington. Deep rose.

\section{SALMON}

1524-Barbara, Fine salmon.

1525--Stirling Stent. Salmon-orange.

SCARLET

1526-Hawlmark Scarlet. True scarlet.

WHITE

1527-Edna May, Imp. Large white waved. MAROON

1528-Othello. Dark maroon

1529-Warrior. Deep maroon.

\section{ORANGE}

1530 - Tangerine Imp. Glowing orange.

1531-Helen Lewis. Orange-pink.

1532-George Shawyer. Giant orange-salmon.

1533-The President. Orange-scarlet.

$$
\text { PICOTEE }
$$

1534-Youth. Large white pink picotee.

\section{Spencer Mixed}

The distinguished characteristics of the new Spencer Sweet Peas are the splendid form and gigantic flowers, which are waved and fluted, which often measure two inches across. The stems are very long and strong, and often bear four blossoms, which remain in bloom much longer than other sweet peas. This mixture includes all the Spencers we describe above, besides many other varieties to make a well balanced array of color and beauty. As sweet peas are one of our specialties, we aim to surpass all others in our sweet peas and we give our mixtures our special attention.

1535-Spencer Mixed. Pkt., 10c; oz., 15c; 1/4 lb., 50c; 1 lb., \$1.75, postpaid.

\section{Sweet Peas}

CULTURE. A deep rich moist soil is best suited for the growth of sweet peas. The ground should be worked or dug to a depth of six inches to one foot and mixed with bone meal or well rotted stable manure, leaving a hollow three inches deep for the seedbed. Sweet Peas should not be grown on the same soil incer the to soil from another part of the garden or grounds. Sow early, covering about one inch deep. Spring sowing should be made just as soon as the ground can be prepared. After the plants are two inches high, cultivate as they grow and a slight sprinkling of Flora Fertilizer worked into the soil will be a great benefit. When the plants are about 5 inches high some support should be furnished, such as brush, strings, wire netting, etc. One ounce of seed will plant 10 feet of drill.

\section{Spencer or Orchid Flowering Varieties}

TRUE SPENCER SWEET PEAS (Orchid Varieties). Many people believe that the Spencers are nothing more than large flowering varieties and selected from the common strains of sweet peas. But this is not true, for Spencer from the common strains of sweet peas. But this is not true, for Spencer gigantic size attained through Spencer strains could never be found in the comgigantic size attained through Spencer strains could never be found in the comvery best types of separate colors, those that we know will give satisfaction. very best types of separate colors, those that we know will give satisfaction.
Our Mixed Spencers contain all the standard varieties, including our selection of straight colors.

There are hundreds of varieties of sweet peas, and yet there is but a slight difference in many of the sorts and it is almost impossible for growers of sweet peas to decide and select the best varieties, so this year we are listing only the finest and best varieties of each class. For instance, there are many varieties of scarlet, but we list Hawlmark Scarlet, which has proven the best the world over.

\section{PRICES OF NAMED VARIETIES}

Pkt., 10c; oz., 20c; $1 / 4$ lb., 65c; lb., $\$ 2.25$, pastpaid.

$$
\text { BLUE }
$$

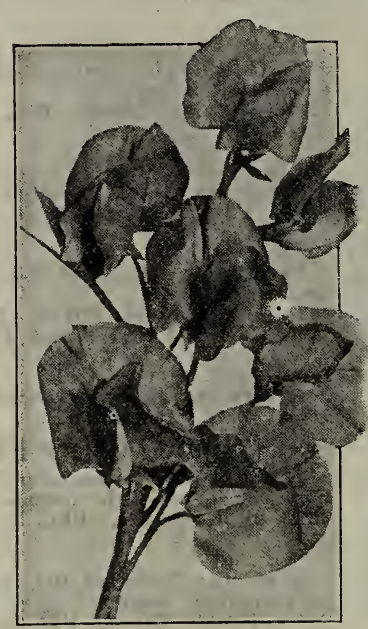

1501--Colne Valley. Light blue.

1502-Mrs. Tom Jones. Bright delphinium blue.

1503-Wedgewood. Azure blue.

1504-Commander Godsall. Violet-blue.

CARMINE
1505-Renown. Carmine rose. CERISE

1506-Royal Salute, Rich fiery cerise. 1507--Hawlmark Cerise. Rose-cerise. CREAM

1508-Dobbie's Cream. Deep primrose. 1509 -Matchless. Cream.

$$
\text { CRFAM PINK }
$$

1510-Margaret Atlee. Giant cream-pink. CRIMSON

1511-Crimson King. Rich deep crimson. 1512-King Edward. Crimson self.

\section{LAVENDER}

1513-Austin Frederick, Imp. Giant lavender. 1514-Asta Ohn. Lavender-mauve.

1515-R. F. Felton. Rosy lavender.

1516-Hawlmark Lavender. Pure pale lavender. 1517-Gladys. Lilac lavender.

\section{PINK}

1518-Hercules. Mammoth rosy pink.

1519-Enchantress. Heavy blooming pink. 1520-Afterglow. Pink lilac.

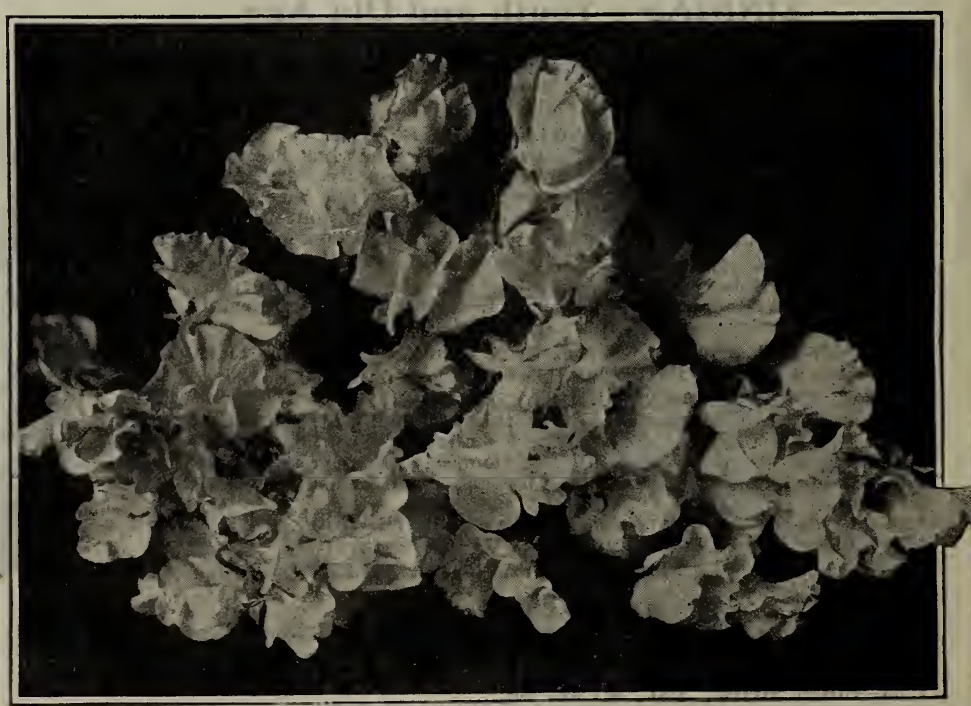

Spencer Type Sweet Peas. 


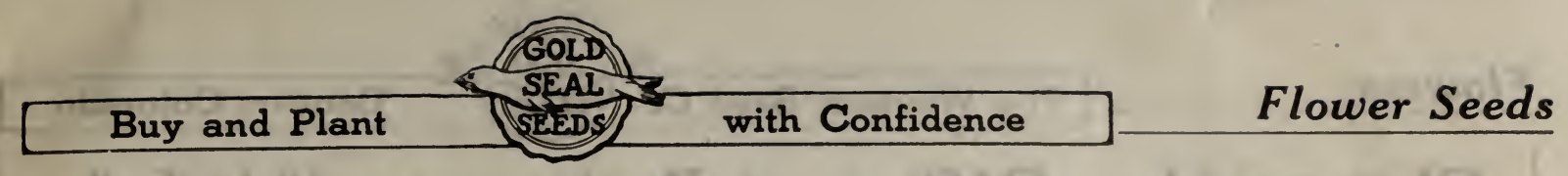

\section{SWEET PEAS-Continued.}

\section{California Giant Sweet Peas}

While the California Giant Sweet Peas are not as waved as the While the they are very beautiful and produce an abundance of flowSpencers, yet they are very beautiful and produce an abundance of howers of a large array of colors. They are a little easier to grow than
the Spencer varieties. Culture is the same as the Spencer. All varieties the Spencer varieties. Culture is the
of sweet peas do best in new soil.

\section{PRICES OF NAMED VARIETIES}

Pkt., 5c; oz., 15c; $1 / 4$ lb., $40 \mathrm{c}$; $1 \mathrm{lb}$., $\$ 1.25$, postpaid. 1636-Dorothy Eckford. One of the best of all white sorts. 1637-Hon. Mrs. Kenyon. The best yellow to date.

1638-Prima Donna. Pure pink, large flower.

1639 - Prince of Wales-Rose crimson.

1640-Lady Grisel Hamilton. Best lavender, giant flowered.

1641-Black Knight. Deep maroon.

1642-King Edward. Bright red. Large flowers.

1643-Captain of the Blues. Purplish mauve.

1644-Navy Blue. Brilliant blue.

1645-America. The brightest blood red, striped white.

1646-Miss Wilmot. Orange pink, wings rose.

Any seven 5c packages of the above California Giants, $25 \mathrm{c}$.

1647--Gold Seal Mixture. Every color of the rainbow. An almost unlimited variety of shades, tones and combinations of colors. The best limited vartesirable mixture possible to make, including the large flowand most desirable mixture possible to make, inchuding the large flowering sorts and many magnificent Spencers. It is made up regardless of expense. This mixture was especially made to
Pkt., 5c; oz., 10c; $1 / 4 \mathrm{lb}, 35 \mathrm{c} ; 1 \mathrm{lb}, \$ 1.00$, postpaid.

1648-Striped Varieties, Mixed. A beautiful mixture made up exclusively of striped, mottled, and flaked varieties. Pkt., 5c; oz., 15c ; $1 / 4$ lb., $50 \mathrm{c}$; 1 lb., $\$ 1.25$, postpaid.

1649-Solid Color Mixture. This mixture consists of the most beautiful varieties of solid colors for many of our patrons do not care for the striped or variegated varieties, but prefer a mixture containing such colors as red, scarlet, violet, blue, purple, white, pink, lavender, maroon, etc. Pkt., 5c; oz., 15c; 1/4 lb., 50c; 1 lb., $\$ 1.50$, postpaid.

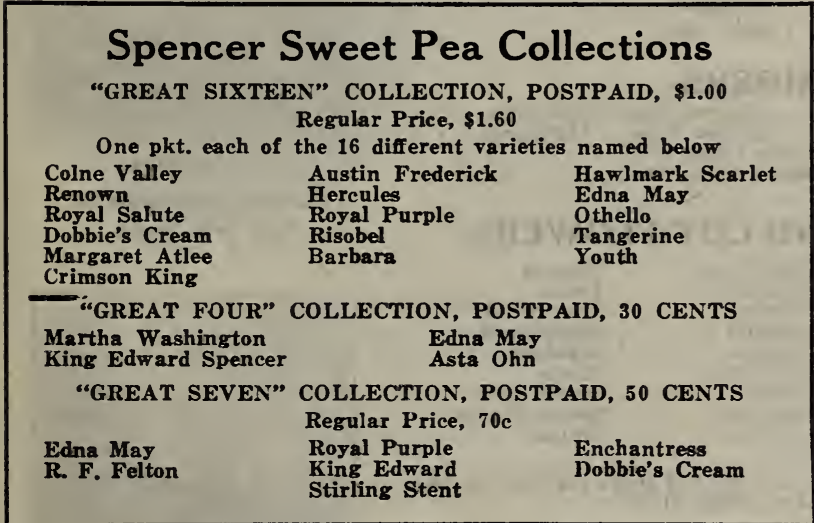

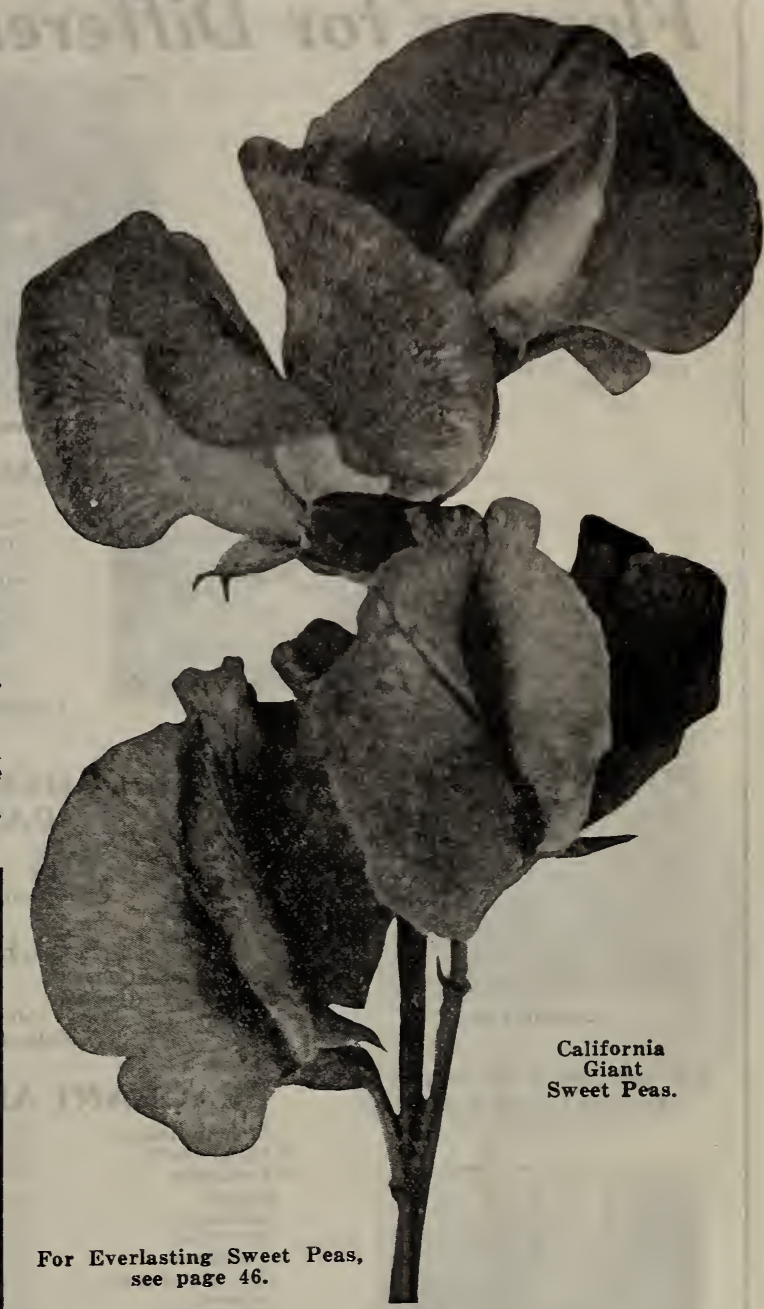

\section{Herbs}

ANISE. An annual, cultivated principally for the seeds, which have a fragrant smell and pleasant taste. Used for medicinal purposes; leaves used for garnishing and flavering. Pkt., 5c; oz., 10c ; $1 / 4$ lb., 35c; lb., \$1.25.

BASIL, SWEET. A hardy annual from the East Indies. Seeds and stems have a fiavor similar to cloves and are used for flavoring soups. Pkt., 5c; 0z., 15c; $1 / 4$ lb., 45c; lb., $\$ 1.50$.

BORAGE. Leaves used for flavoring, and flowers furnish bee pasturage; most easily grown in any waste place. Pkt., 5c; oz., 15c ; $1 / 4$ lb., 40c ; lb., \$1.25.

CARAWAY. Cultivated for its seed, which is used in confectionery, cakes, etc. Leaves are sometimes used in soups. If sown in August plants will give a fair crop the next season, but when sown
in the Spring will not generally seed until the next year. Pkt., 5c; oz., $10 \mathrm{c}$; $1 / 4$ lb., $25 \mathrm{c}$; 1b., $75 \mathrm{c}$.

CATNIP. Leaves and young shoots used for flavoring. Pkt., 5c; oz., 35c.

CORIANDER. A hardy annual, cultivated for its seed, which has an agreeable taste and is used in confectionery and to disguise the taste of medicine. Pkt., 5c; oz., 10c; $1 / 41 \mathrm{lb} ., 20 \mathrm{c} ; 1 \mathrm{~b} ., 60 \mathrm{c}$.

DILL. An annual, cultivated for its seed, which is aromatic and has a warm pungent taste. Its seeds are used for seasoning. It possesses medicinal values but its largest use is for seasoning in dill pickles. Pkt., 5c; oz., 10c; $1 / 4$ lb., 25c; 1b., 75c.

LAVENDER. An arematic and useful medicinal herb. Plt., 10c; oz., 30c; $1 / 4$ lb., 85c; lb., \$3.00.

SWEET FENNEL. A hardy perennial ; leaves used in soups, fish, sauces, garnishes, and salads. Plt., 5c; oz., 15c; $1 / 4$ lb., 45 ; lb., $\$ 1.50$.
HOREHOUND. A perennial herb with a strong aromatic smell: bitter tion of cough syrups. Does fine in poor soils. Pkt., 5c; oz., 35c; $1 / 4$ lb., $\$ 1.10$.

ROSEMARY. The leaves are aromatic and used for medicinal purposes only. Pkt., 10c; oz., 45c; $1 / 4 \mathrm{lb}$., $\$ 1.35$.

SAVORY, SUMMER. A hardy annual; when dried, stems, leaves and fowers are extensively used for soups and dressings. Pkt., 5c; oz., 15c; $1 / 4$ lb., $40 \mathrm{c}$; lb., $\$ 1.25$.

SAFFRON (Carthamus tinctorius). Used in medicine and also in dye. Pkt., 10c; $1 / 2$ oz., $25 \mathrm{c}$.

THYME. A perennial used both medicinally and as a culinary plant. The young leaves and tops are used for soups, dressings, and sauces. A tea made of the leaves sometimes relieves nervous headaches. Pkt., 10c; oz., 30c; 1/1 lb., 85c; lb., $\$ 3.00$.

SWEET MARJORAM. A perennial plant but not hardy enough to stand the northern winters. Young tender tops are used for flavoring and may be cut and dried for winter use. Pkt., 10c; oz., 30 c : $1 / 4$ lb., 85c; lb., $\$ 3.00$.

SAGE. A hardy perennial, possessing some medicinal properties, cultivated principally as a condiment, being used more extensively than any other herb for flavoring and in dressing. Pkt., 10c; oz. $30 \mathrm{c}$; $1 / 4$ lb., $\$ 1.00$; lb., $\$ 3.50$.

SORREL. Broad leaved perennial, used in soups and salads and sometimes cooked like spinach. Pkt., 5c; oz., 10c; $1 / 4 \mathbf{4 b}$. 35 c lb., $\$ 1.00$.

WORMWOOD. Leaves used as a tonic. A dry poor soil is best for this plant. Pkt., 5c; oz., $15 \mathrm{c} ; 1 / 4$ lb., $45 \mathrm{c}$; lb., $\$ 1.50$. 


\section{Flowers for Different Purposes All Are Easily}

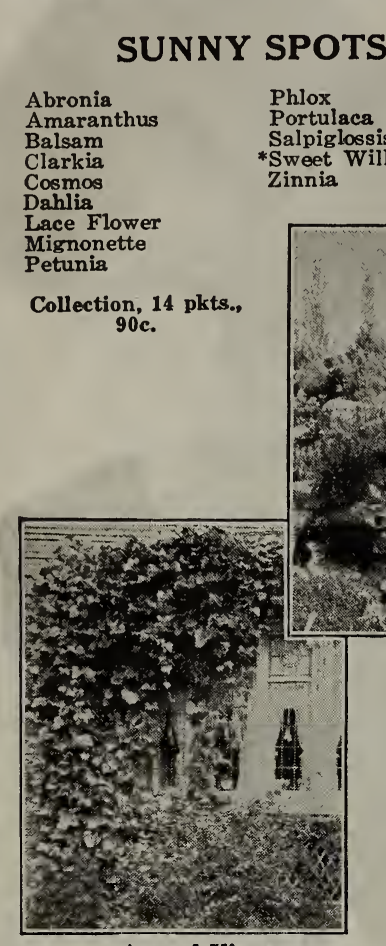

Annual Vines.

Try Gold Seal Seeds in Your

Favorite Garden Spot.

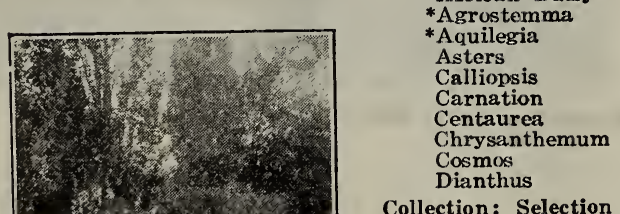

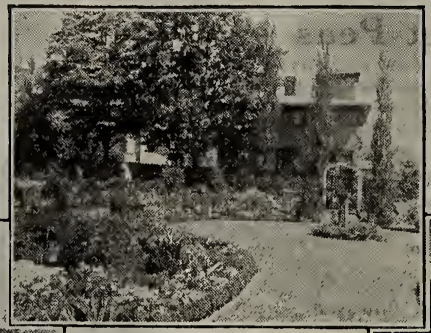

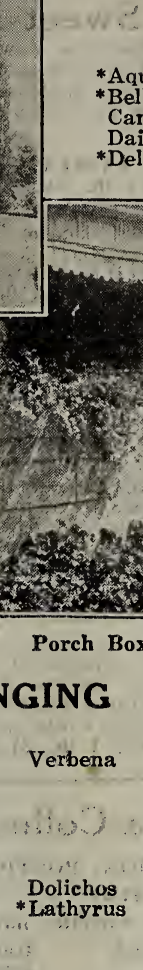

Balloon Vine Humulus
Sunny Spots.

\section{DAMP SPOTS}

*Delphinium *Heliotrop * Lobelia

*Pansy

* Snapdragon

* Snaprock

Stocks
*Wallflower

Collection, 8 pkts. $55 \mathrm{c}$.
Damp Spots.

PORCH BOXES and
BASKETS

Browallia $\quad$ Lobelia

Collection, 7 pkts., 35 c.

\section{CLIMBERS}

\section{\begin{tabular}{l|l} 
Cobaea & $\begin{array}{c}\text { Cypress Vine } \\
\text { *Kudzu Vine }\end{array}$ \\
Ipomoea & Dolichos \\
LLathyrus
\end{tabular} Morning Glory Collection, 9 pkts., 60c.}

NATURALIZING

*Digitalis

*Hollyhock

*Labelia

* Myosotis

Petunia

Phlox

*Poppy

*Sweet William

Collection, 14 pkts., $\$ 1.10$.
FRAGRANT AND CUT FLOWERS

$\begin{array}{lll}\text { African Daisy } & \text { Eschscholtzia } & \text { Petunia } \\ \text { *Agrostemma } & \text { Everlastings } & \text { Poppy } \\ \text { *Aquilegia } & \text { Gaillardia } & \text { *Pyrethrum } \\ \text { Asters } & \text { Gypsophila } & \text { Salpiglossis } \\ \text { Calliopsis } & \text { Heliotrope } & \text { Sabiosa } \\ \text { Carnation } & \text { Lace Flower } & \text { Stocks } \\ \text { Centaurea } & \text { Marigold } & \text { Sweet Peas } \\ \text { Chrysanthemum } & \text { Mignonette } & \text { *Sweet Rocket } \\ \text { Cosmos } & \text { Nasturtium } & \text { Zinnia } \\ \text { Dianthus } & \text { Pansy } & \end{array}$

Collection: Selection of 1 pkt. each of 12 of above varieties for $90 \mathrm{c}$ or the 29 pkts. listed, $\$ 1.75$.

The varieties marked with an asterisk $(*)$ are best treated as perennials.

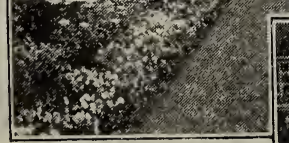

ROCK

GARDENS

Abronia

Alyssum

Candytuft

Ice Plant

Portulaca

Collection, 6 pkts.,

$25 \mathrm{c}$.

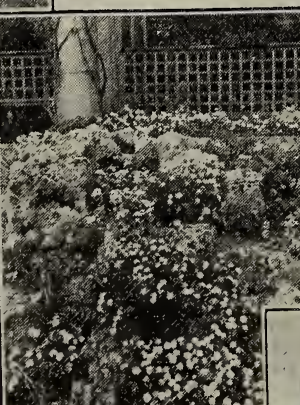

Backgrounds

Cosmos

*Delphinium

* Digitalis

* Digitalis

Rock Garden.

MASSED COLORS

$\begin{array}{ll}\text { Ageratum } & \text { Phlox } \\ \text { Candytuft } & \text { Poppy } \\ \text { Celosia } & \text { Portulaca } \\ \text { Helichrysum } & \text { Salvia } \\ \text { Nasturtium } & \text { *Sweet William }\end{array}$

Collection, 11 pkts., $60 \mathrm{c}$.
Collection, 4 pkts., $25 c$

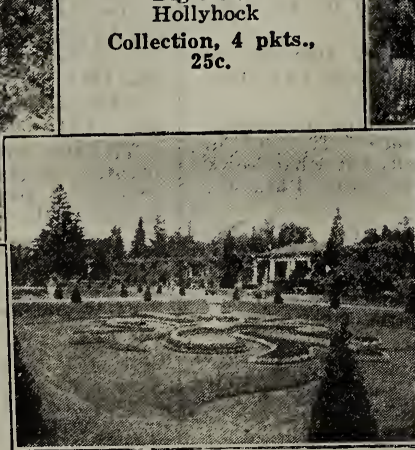

Massed Colors.

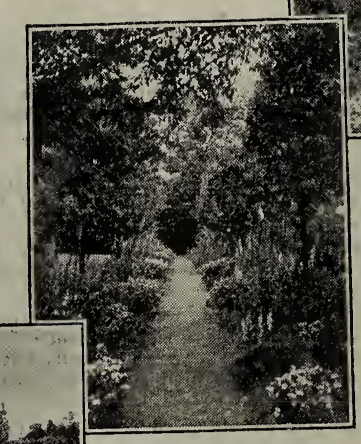

Naturalizing.

No Disappointments in Gold Seal Seeds.

Shaded Corners.

\section{EDGINGS}

$\begin{array}{ll}\text { Alyssum } & \text { Nasturtium } \\ \text { Candytuft } & \text { Pansy } \\ \text { Dusty Miller } & \text { Petunia } \\ \text { Lobelia } & \text { Phlox } \\ \text { Marigold, Fr. } & \text { Portulaca } \\ \text { Above Collection, 50c bought separately } & \text { costs 75c. }\end{array}$




\section{Nursery Stock for the West}

\section{Fruit and Shade Trees, Berries, Small Fruits, Roses, Plants and Roots}

\section{Our Stock is State Inspected and is Free From Disease}

\section{Suggestions to Planters}

We have a good supply of carefully grown nursery stock: fruit and shade trees, roses, shrubbers, plants, etc., and we believe our prices are sufficiently low to be attractive However, it is the quality and not the prices that we wish to call your attention to. Our stock is all number one and includes all the varieties which are popular and that do well in our western elimate. We, therefore, feel confident that your requirements will be taken care of to your entire satisfaction. You may be able to buy at a lower price, but not of the same quality. Remember, a low grade tree does not have the vitality to show a prolific growth and is alwass a rather poor tre throughout its life. Therefore, it is a very poor investment.

Success depends in a large measure on the treatment given to steck after it is received bs the planter. Thousands of well growp stealthy specimens delivered in first-class condition, or annually lost healthy specimens delivered in first-class condition, are annually lost throes is in the ground; preparation for their arrival should be made, everything should be ready and the trees or shrubs planted as soon as possible. As soon as jou receive your nursery stock, remove the packing, sprinkle the roots and heel in the bundle in moist ground, covering entirely about 4 to 6 inches. In planting take up only a few trees or shrubs at a time and never allow them to lay exposed to the air and sun at any time. Remove all broken roots with a sharp knife and cut back the tops about one-hall of last season's growth. Dig the hole large enough to admit all the roots in the natural position, keeping the surface soil and the sub-oil separate. In filling in sift the best soil in around the roots. When most of the soil is filled in, pour in the water to wash the soil around the roots, then pile up the remainder and tread down gently with the foot. After this the tree or shrub should only be genty with the soil gets dry about two or three inches below the surface. A mulch around the base of the tree, two or three inches thick, is very
beneficial.

\section{Prices}

Our prices on nursery stock include packing and drayage to freight or express depot, but not prepay charges. The purchaser is to pas the freight or express charges unless arrangement has been made with us before goods are shipped. Mail us your list and we will make you a special delivered price.

Upon special request we will ship fruit trees by mail but they must be cut down to comply with postoffice rules and buyer must assume risk of safe delivery.

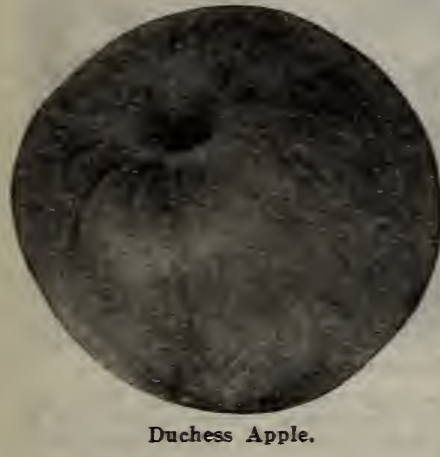

\section{Autumn Apples} MAIDEN BLCSH. Medium size, round, flusbed with red on creamy yellow; very handsome; tender flesh.

WEALTHY. The most popular early variety known; heavy producer of medium size, red apples. One of the finest early eating or cooking varieties; everyone should plant Wealthy apples.

DUCHESS OF OLDENBURG. A large sized apple of sellow color, streaked red. Very juicy and a heary rielder. Ripens in September. One of the best for Colorado.

\section{Winter Apples}

DELICIOLS. A most wonderful apple of unusually fine flavor: criginated in our western country. The fruit is large, of a brilliant, dark red color; juics, crisp, and melting. Heavy cropper.

GRIMES' GOLDEN. Medium sized, beautiful golden color; does well in the West; splendid keeper.

JONATHAN. The old standby-heary producer, brilliant red, sweet and juicy; excellent keeper.

MAMMOTH BLACK TWIG. A large, dark red apple; fine eating and cooking; good keeper.

NORTHWESTERN GREENING. Very late to ripen, but keeps solid a long time, rich golden color; very productive.

ROME BEAUTY. Extra large and handsnme, sellow, with crimson cheek; juicy and bears heavy.

STAYMAN'S WINESAP. Larger and more prolific than the old Winesap. Rich dark red firm, fine grained and juicy. Adapted to a wide range of soils and climates.

NORTHERN SPY. Vigorous growth; large, striped red, tender, juics, mild, sub-acid; ver good. A fine dessert fruit. Keeps through Winter and late into the Spring.

\section{APPLES}

\section{Summer Apples}

作 ( (n) frean when full ripe, of medium size, tender and good; free-growing and fruitful. Its early fruit is alwass wel(n) proven a

rieties of apples and crab apples: First .

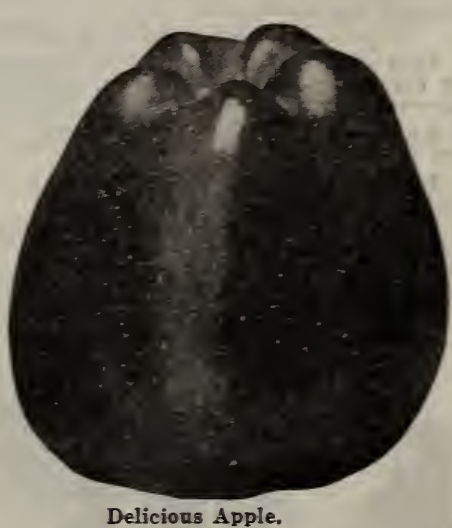

\section{Crab Apples}

HYSLOP. Large size, beautiful dark crimson, hangs in clusters. Fine for preserving. Very well known.

RED SIBERIAN. Large strong grower, pale red-yellow; good quality. Tree larze, with coarse foliage; young bearer. Fruit about 1 inch in diameter.

WHITNEY (Golden Beauty). One of the largest; jellow striped with red; excellent for cider and cooking.

FLORENCE. Originated in Minnesota. Fruit of medium size, color carmine, flesh rellowish, fine, acid, excellent for cooking and for jelly. Early bearer.

\section{PEARS}

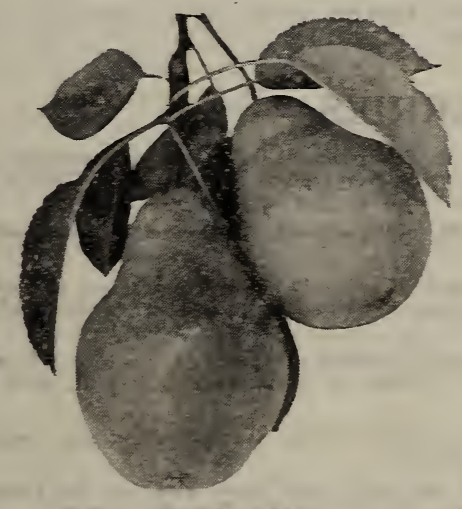

Bartlett Pears.
Prices on all rarieties of pears: First grade, $11-16^{\circ}$ and up in diameter, 5-7 high: each, $\$ 1.00$; in lots fire to ten, each, $90 \mathrm{c}$.

BARTLETT. Large, buttery, juicy, high flavored; bears early and abundantly.

FLEMISH BEAUTY. Large, red cheeked and beautiful, of excellent quality. hardy, and productive. Very popular in the Test. Ripens September and October.

KIEFFER. Its large size, handsome appearance and remarkable keeping gualities make it very desirable Ripens October and Novem. ber.

First grade, 5-8 $\begin{gathered}\text { DWARF } \\ \text { and up, } \$ 1.00 \text { each. }\end{gathered}$

BARTLETT. Same as the standard variety. DUCHESS. Flesh white with rich buttery favor, very large. 


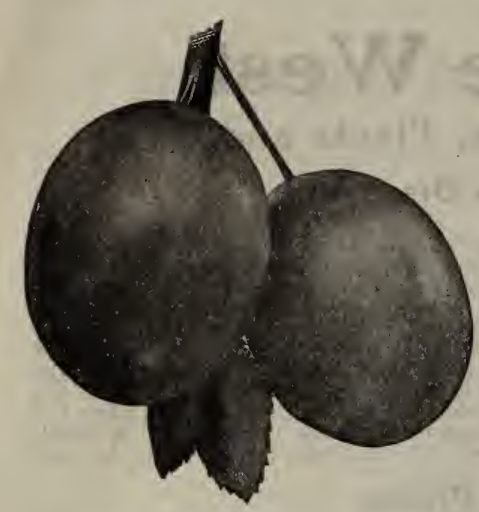

Lombard Plums.

\section{PLUMS}

The plum may not be so important as some other fruits, but it is gaining more in popularity every year and has been planted extensively the last few years. As it is a native fruit it grows easily and is a great bearer and should have a place in every orchard and fruit garden. Our list is confined to the American varieties, with the exception of one, because they are better adapted to our locality.

\section{PRICES ON ALL VARIETIES OF PLUMS}

First grade, 11-16" and up in diameter, 5-7' high; each, $\$ 1.25$; in lots of five to ten, assorted varieties if desired, each, $\$ 1.10$; larger a mounts, assorted varieties if desired, each, $\$ 1.00$.

LOMBARD. Medium to large; dark red, flesh yellow; of pleasant flavor, very prolific and does well in this locality.

MOORE'S ARCTIC. Small, purplish black, juicy, sweet, immense bearer. One of the hardiest in bud and bloom.

OMAHA. Medium size, dark red, of good quality; very hardy and heavy bearer under all conditions and ripens early. One of the most popular plums.

OPATA. A cross between Dakota Sand Cherry and the Japanese Gold Plum. A good grower, early and very productive; fruit dark purplish red color, with green flesh of a very pleasant flavor.

HANSKA. This is a cross between the Native Plum and the fragrant apricot of China. It is hardy and a strong grower; fruit of bright red color, with heavy blue bloom. Flesh is firm, yellow, of good quality and very fragrant.

WANETA. This wonderful large plum of Professor Hansen's production is the most delicious of all plums. It is hardy and very prolific; fruit of largest size, deep red color and a de-

\section{CHERRIES}

More satisfaction can be had from cherry trees than any other trees. They are a beautiful sight from blossom to fruit and very seldom fail to produce; every farm, garden or ranch should have cherries. They do not demand much attention.

\section{PRICES ON ALL VARIETIES OF CHERRIES}

First grade, 11-16" and up in diameter, 5-7' high, each, $\$ 1.40$; in lots of five or ten, assorted varieties if desired, each, \$1.25. Larger amounts, assorted varieties if desired, each, $\$ 1.15$.

EARLY RICHMOND (Pie Cherry). A reliable old standard, with dark red fruit of medium size, very productive.

ENGLISH MORELLO. Large; dark red, nearly black; tender, juicy and rich. Tree is dwarf-midseason.

LARGE MONTMORENCY. Larger and finer than the Richmond and one LARGE MONTMORENCY. Larger and finer than the Richmond and one
of the finest favored cherries in this class; valuable for canning and preserving.

OSTHEIMER. A perfectly hardy, late blooming, immensely productive variety. Large, heart-shaped, nearly black when ripe; juicy and rich.

WRAGG. Very hardy, vigorous and productive, medium dark purple, fine

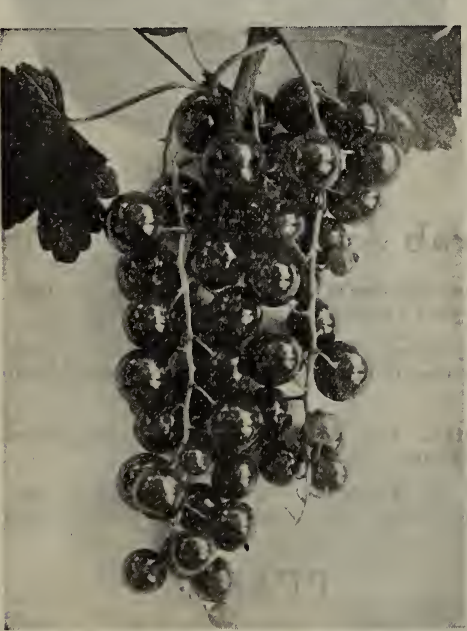
quality. Usually sure cropper. will bring greater returns in money. post, add $2 \mathrm{c}$ per plant. the table.

\section{licious flavor.}

GREEN GAGE. Large, round ovate; green, marked with red in the sun; hangs long on the tree. Ripens in September. WILD GOOSE. Well known, large deep red when ripe, of good quality. One of the best native plums.

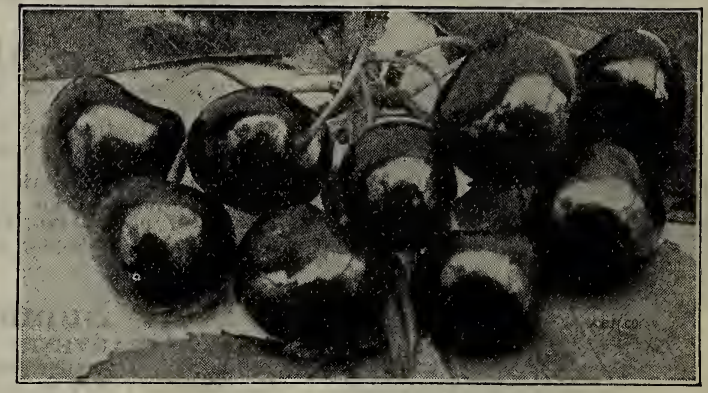

Large Montmorency Cherries.

COMPASS CHERRY. This fruit is a cross between the Sand Cherry and Miner Plum and looks more like a cherry than a plum. It is absolutely hardy everywhere. Fruit is one inch in diameter, of bright red color and of good flavor, very fine for preserves. An early bearer, often bearing fruit the next year after planting. Every back yard should have at least one or two trees.

\section{CURRANTS}

The currant is an indispensible garden fruit for the table and is a money maker, as well. It grows and bears easily in any kind of soil with very little care, but if properly cared for it

Prices, two-year-old plants, each, 25c; 5 for $\$ 1.00 ; 10$ for $\$ 1.90 ; 100$ for $\$ 17.00$. If by parcel

CHERRY. Very large berries on short clusters; a robust, fruitful sort.

LONDON MARKET. Bush vigorous, upright, with perfect foliage. Fruit is large in berries and clusters, dark red and an enormous cropper. Fine for market and table use.

PERFECTION. A cross between Fay and White Grape, retaining the valuable characteristics of both. Beautiful bright red, larger than Fay, holding its size to end of bunch; easy to pick; a superior bearer, less acid and of better quality than any other large currant in cultivation.

WILDER. One of the strongest and most productive. Bunch and berries very large, attractive bright red color, and even when dead ripe they hang on bushes in fine condition for handling until very late. A valuable market variety.

WHITE GRAPE. Very large, yellowish white. Fruit excellent quality and valuable for Perfection Currants.

\section{GOOSEBERRIES}

The gooseberry differs little from the currant in its requirements as to soil and general care. The plant is hardy; a vigorous grower, and free from mildew in our climate. The fruit is used extensively for cooking and canning as one of the popular berries for pies and jelly.

Prices, each, 25c; per 10, $\$ 2.00$; per $100, \$ 17.50$, not postpaid. If by parcel post, add $2 c$ per plant.

DOWNING. A large and handsome pale green berry of splendid quality for dessert or cooking. The bush is robust and seldom mildews. An excellent sort for family use and quite profitable
. A late for the market.

HOUGHTON. An enormously productive and always reliable old sort; of vigorous yet rather slender, spreading growth, not subject to mildew. Fruits of medium size, smooth, pale red; tender and good.

JOSSELYN. Large size, smooth, prolific, hardy and best quality. Least susceptible to mildew, both leaves and fruit, of them all. A wonderful cropper.

OREGON CHAMPION. Berries large, brownish red color, very sweet and fine for table use and pies. Bush a strong grower, healthy, and a very prolific bearer. Fine for market.

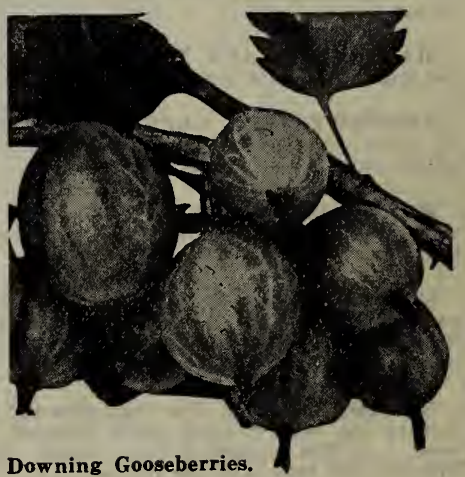




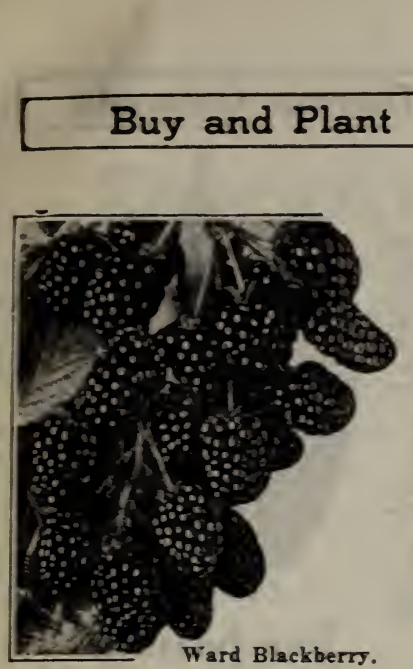

with Confidence

Fruit

\section{BLACKBERRY PLANTS}

Raspberries and blackberries are rery profitable fruits for the home and market. They are of delicious flavor and ean be used for the table in mang ways.

Prices, each, 10e; per 10,60c; per 100, \$4.00, not postpaid. If by pareel post, add 1c per plant.

ELDORADO. Of late introduction, being vigorous and hardy in most localicies. The berries are large col black, flavor sweet and melting and have no bard core. Very firm and therefore an ereellent market variety.

SNTDER Berries of medium size, sweet, melting. Verg hardy and wonderfully produetive. Valuable for cold climates, as it leads where kardiness is a consideration. Early.

WARD. Originated in New Jersey. A seedling of Kittatinns, which it resembles, baving all of its good qualities and none of its defects. Healthy, strong grower, with sturdy canes producing fine, large fruit, black throughout, without core, and of excellent quality. The bushes are corered with its fine fruit

EARLY HARVEST. Its earliness, combined with good shipping qualities, makes it a very profitable rariety. The fruit is of medium size, firm, and attractive in appearance. Dwarf and compact grower.

\section{BLACK RASPBERRY PLANTS}

CUMBERLAND. "The business Blackeap." It is of wonderful productiveness; producing regularly and uniformly very large crops. In size the fruit is simply enormous, far surpassing any other variety.

GREGG. Early; rery large and productive.

KANSAS BLACKCAP. Berries lange; heavy bearer.

\section{RED RASPBERRY PLANTS}

Prices, each, $10 \mathrm{c}$; per $10,60 \mathrm{c}$; per $100,23.50$, not postpaid. If by parcel post, add $1 \mathrm{c}$ per plant.

CUTBBERT. A strong grower and very productive, large bright red, fruit firm, of vert fine quality. Season medium to late; a good one for market or home use. Is doing very fine quality.
well everywhere.

KING. Several of our best fruit growers consider this the best of the red raspberries. It has large and attractive, bright red fruit, of good flavor; ripening with the earliest and firm encugh to keep for some time, in hardiness and productiveness all that could be desired.

LOUDEN. This rariety is a marrel of productiveness and hardy to the tips of its shoots. Its lange and beautiful, rich, dark crimson fruits are of good flavor; ship better and hang longer after ripening than those of any other variety.

MARLBORO. A profitable early market berry, with large erimson fruits of good quality and firmness. This variety is very hardy and well suited to the North.

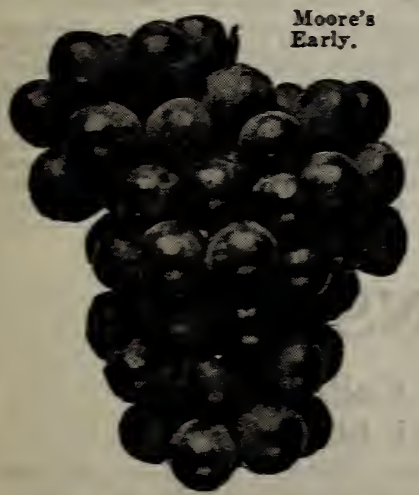

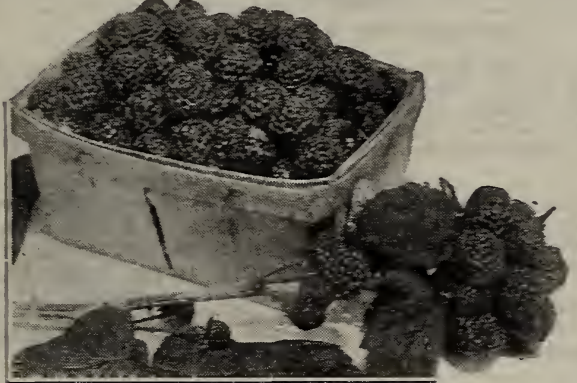

Cumberland Black Raspberries.

\section{HARDY GRAPE VINES}

Everyone should plant grapes in the home garden. No part of the fruit garden gives you rreater pleasure and more satisfaction than the greater pleasure and more satisfaction than the any ordinary soil. They can be trained over frames, trellises or doorways and are ornamental as well as useful. Make jour own grape juice.

CONCORD (Black). The fine old market leader, with large, handsome clusters of big luscious grapes. Entirely hardy, productive and reliable: succeeds well over a great extent of country.

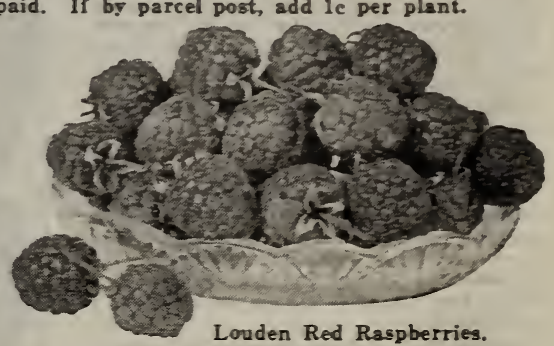

\section{EVERBEARING RASPBERRIES}

ST. REGIS. Berries bright crimson, of large size, fine and meaty, with a rich, luscious, true raspberry flasor. It is wonderfully prolific, the fruit beginning to ripen with the earliest and continuing well into Ostober. The canes are stocky, of strong growth, with an abundance of dark green, feathery foliage Prices, each, 10c; per 10, 70c; per $100,84.00$, not postpaid. If by parcel post, add le per plant.

\section{DEWBERRIES}

LUCREFIA. In size and qualits this lowgrowing or trailing blackberry equals any of the upright sorts. Its berries ripen before raspberries are gone, are large, soft, sweet, and luscious throughout, with no hard core. The vine is perfectly hards, healths, and exceedingly fruitful with large showy blossoms. ceedingly fruitful, with large showy blossoms. May be grown orer walls, trellises or rocky slopes, where there is no room for other berries.
Prices, each, 10c; per $10,65 \mathrm{c}$; per $100, \$ 4.00$. not postpaid. If by parcel post, add le per plant.

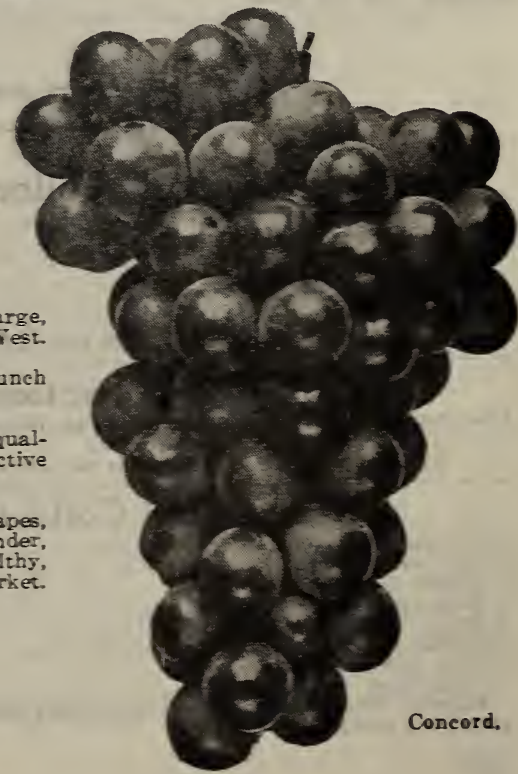

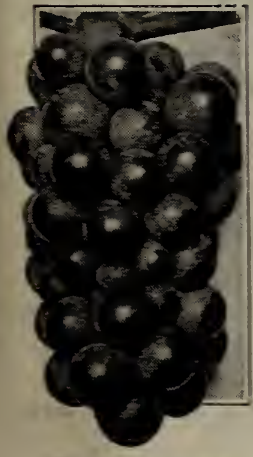

MOORE'S EARLY (Black). Clusters of medium size; berries large round, black, with heary blue bloom. Extra early, successful in the West

NIAGARA (The White Concord). One of the leading white sorts, bunch large, compact; berry large yellowish white.

WORDEN (Black). Resembling the Concord, but larger and better qual ity, and five to ten days earlier. A vigorous, hardy, and very productive grower.

WTOMING (Red). One of the most beautiful of the red or amber grapes, brighter colored than Delaware, earlier, nearly twice as large; flesh tender, juicy, sweet, with a strcng, native aroms. The vine is hards and healthy, with thick, leathery foliage. The best of the red grapes for early market.

\section{Prices of Grapes}

Concord-Each, $20 \mathrm{c}$; per 10, $\$ 1.75$; per $100, \$ 15.00$.

Other Varieties-Each, 25e; per 10, \$2.00: per 100, $\$ 18.00$.

Not postpaid; if by parcel pust, add $2 \mathrm{e}$ per plant. 


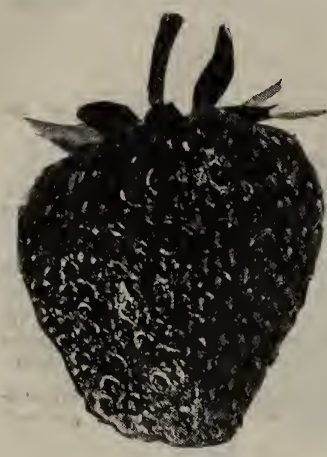

Hood River.

\section{Strawberries}

CULTURE. A good many people overlook the strawberry, thinking the plants demand too much care, but this is not true. Strawberries will succeed in any soil that is adapted to ordinary farm or garden crops. For fiel culture set in rows three feet apart, 18 inches in rows; for garden, 15 inche each way, leaving pathway every third row. The ground should always be kept clean and well cultivated. In Winter a covering of leaves, straw or some kind of litter will protect the plants. Do not cover them until the ground is frozen, or so deep as to smother plants, and remove covering before growth starts in the Spring.

\section{Standard Varieties}

AROMA. A large, bright scarlet berry of a roundish, conical shape. Not A canning and shipping berry.

FREMONT WILLIAMS. A new, large, late season strawberry that has proven itself for western and more particularly the Denver market. The
berries are very large, blunt-shaped, glossy and unsurpassed in beauty.

As a shipper, it is hard to beat on account of its firmness. The plants make a large bush and winter better than any other variety known. On account of its good keeping quality it makes an excelgood keeping quality it makes an excellent shipper. If you want a large, wellshaped strawberry that w'll outsell anywonder.

DR. BURRILL (The Million Dollar Strawberry). The Gem of Perfection. Berries large, dark red, of the best qual. ity and uniform in size and shape. This ity and uniform in size and shape. This blooming and fruiting season is extra long and it is a wonderful producer; midseason.

GIBSON. A new variety of merit: bears with Dunlap, but owing to its productiveness continues until quite late; large, glossy berries of good quallate; large, glossy ber
ity. Strong grower.

HOOD RIVER. This variety has won great favor out West, and just before any of our home-grown berries are ready

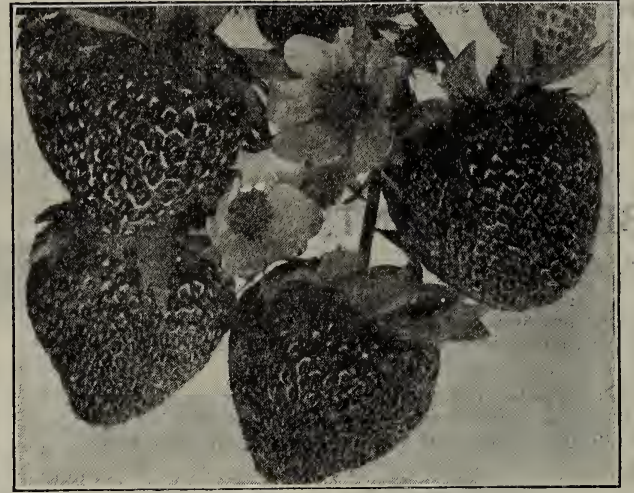

Mastodon-The Best Everbearer.

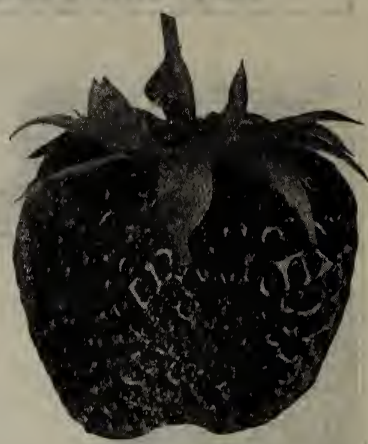

Fremont Williams.

\section{Everbearing} Strawberries our market requires a number of cars of Hood River berries from Oregon, and it was through these shipments that our trade became acquainted with the berry. The Hood River berry produces dark red fruit, very heavily meated, and inRiver berry produces dark red fruit, very heavily meated, and infrom the best berry men of Edgewater, Colorado. For large amounts, from the best berry men
write for special prices.

RIDGEWAY. A very large, midseason, handsome berry, of heavy yielding power; the berries are very solid and stand shipping great distances; very highly flavored and juicy; excellent for preserves. distances; very highly flavored and juicy; excellent
A dandy for either the home garden or the market.

SENATOR DUNLAP. A very hardy midseason variety that produces a heavy yield of large, richly colored strawberries that command good prices on the market. The plant makes a very heavy foliage and is a good keeper through the Winter.

Prices, postpaid: 25 for $40 \mathrm{c}$; 50 for $60 \mathrm{c}$; 100 for $90 \mathrm{c}$. If by express at buyer's expense, 25 for $30 \mathrm{c} ; 50$ for $50 \mathrm{c} ; 100$ for $80 \mathrm{c}$. Not postpaid, 1000 for $\$ 6.50$.

Have your ground ready and we will so you will receive them in nice fresh condition, well packed, just when you are ready for them.

PROGRESSIVE. This is the old variety of everbearing which still holds a prominent place among the everbearing strawberries. It is a strong grower, has dense foliage, fruit medium and dark collored, of the finest flavor. Price, 1 dozen, 25c; 50 plants, \$1.00; 100 plants, $\$ 1.50$; 1000 plants, $\$ 12.00$, postpaid.

SUPERB. Splendid bearer, larger than Progressive, but not so rich in flavor. A strong grower. Price, same as Progressive.

PRIDE OF DENVER. This strictly high class variety is a Colorado product of great merit. It makes a perfect growth during the entire season. The berries are large, deep colored and of excellent flavor. A fine cropper. Price, 1 dozen, 35c; 50 plants, $\$ 1.25 ; 100$ plants, $\$ 2.00$, postpaid.

MASTODON. This new variety is the last word in everbearing strawberries. Mastodon is a thrifty grower, a heavy cropper, berries are of the finest quality and as large again as any other variety. Price, 1 dozen, 75c; 50 plants, $\$ 2.75 ; 100$ plants, $\$ 5.00$, postpaid.

\section{SPECIAL COLLECTIONS.}

\section{Small Fruit Collection}

6 Red Raspberry, Cuthbert ...........................\$0.60

3 Grape, Moore's Early $\ldots \ldots \ldots \ldots \ldots \ldots \ldots \ldots \ldots \ldots \ldots \ldots \ldots \ldots \ldots, .75$

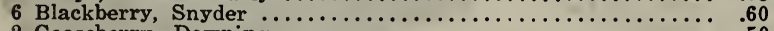

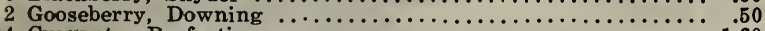

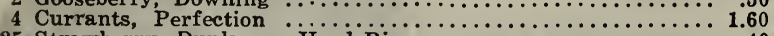

25 Strawberry, Dunlap or Hood River $\ldots \ldots \ldots \ldots \ldots \ldots \ldots \ldots \ldots \ldots . .60$

Regular price, $\$ 4.45$; cost you $\$ 3.50$, postpaid.

\section{Shrub Collection}

\section{Golden Bell 1 Snowberry 4 Van Houttei Spirea 2 Lilacs Regular price, $\$ 8.00$, postpaid; our price, $\$ 6.50$, postpaid.}

\section{Perennial Collection}

2 Oriental Poppy $\ldots \ldots \ldots, \ldots \ldots \ldots \ldots \ldots \ldots \ldots \ldots \ldots \ldots \ldots \ldots, \ldots 0.50$

2 Orien

2 Chrysanthemu

1 Golden Glow

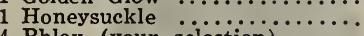

4 Phlox (your selection)

2 Shasta Dais

2 Baby Breath (i............ $\$ 2.75$, not postpaid.

[58]

\section{Dahlia Collection $\$ 1.50$}

We are making a special offer of thirteen good roots, our selecill different colors, no two alike, postpaid, $\$ 1.50$.

This collection contains some of our finest varieties on which we have a surplus.

\section{Dahlia Collection \\ $\$ 1.75$}

We will send postpaid, any eleven of our $20 \mathrm{c}$ dahlias for $\$ 1.75$, your selection.

\section{Dahlia Collection $\$ 2.00$}

We will send, postpaid, any ten, your selection, of our $25 \mathrm{c}$ dahlias, for $\$ 2.00$, postpaid.

\section{Rose Collection}

We will send postpaid, any fiye roses listed at $60 \mathrm{c}$ or $65 \mathrm{c}$ each, your selection, for $\$ 2.75$, or ten for $\$ 5.00$. 


\section{Deciduous Ornamental Trees}

Many people are realizing nowadars that by expending a little time and study they can have well kept and attractive looking grounds, adding to the beauty and comfort of the home and increasing the value of the property. There is an ornamental decidwous tree for almost every purpose, whether for shade, for hiding objectionable sights, or for beauty or utility. Our list comprises all those varieties which are well adapted to our western elimate. You will find many interesting trees, suitable for your individual tastes.

Note: We divide the ornamental trees into two classes-those suitable for street planting, "Class A" " those suitable for lawns, "Class B." "Those that can be used for the letter after each variety.

BIRCH, AMERICAN WHITE (A). A medium sized tree with smooth white bark Bires, will even in poor and dry soils. Very attractive and and handsome foliage. Thrives well even in

AMERICAN ELM (A). 6 to 8 feet. Easily distinguished by its wide, arching top, vase-like form and pendulous branchlets. Next to the oak, this is the grandest and most picturesque of American trees, Yellow or brown in Fall. Price, each, $\$ 1.00$. 10 for $\$ 9.00$, not postpaid.

AMERICAN LINDEX (AB). A stately tree, with large, shining cordate leaves. Valuable for its beautiful white wood; flowers in July. A valuable lawn tree and should be used for this purpose. Price, each, $\$ 1.60 ; 10$ for $\$ 15.00$.

CATALPA SPECIOSA (AB). A handsome large foliaged tree. It is very hardy and a rapid grower; foliage heart shaped and dark green. The flowers are two inches in diameter and come in large pyramidal panicles, color white, striped yellow, dotted reddish and violet. Blooms early in Summer, followed by long seed pods in Átumn. A fine tree for the lawn. 8 to 10 feet. $\$ 1.00$, not postpaid.

CATALPA BUNGEI (Umbrella Catalpa) (B). Grafted on stems five feet high, it makes an umbrella-shaped top without pruning. Perfectly hardy, and flourishes in almost all soils and climates. Leaves large, glossy, heart-shaped, deep green, lying like shingles on a roof; a! wass making a symmetrical head. One of the most unique

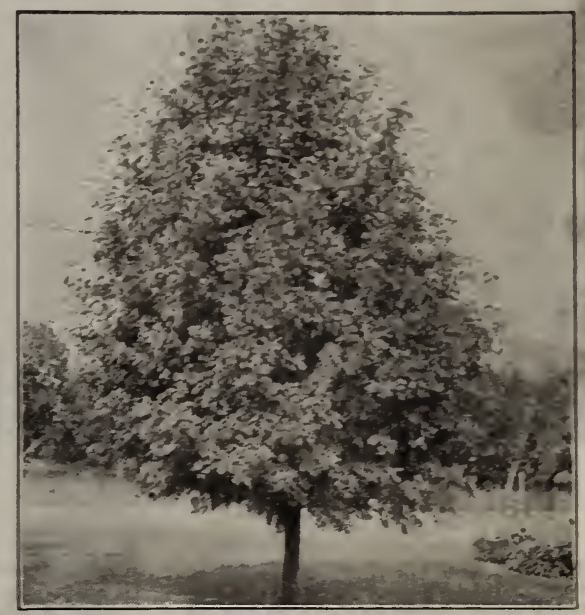

Mountain Ash. trees: desirable for lawn, park and ceme$\$ 16.00$.

CRAB, BECHTEL'S DOUBLE FLOWERING (B) Makes a medium sized tree: perfectly hardy, does well in a medium dry
soil. Blooms appear to be delicate pink, soil. Blooms appear to be delicate pink,
perfectly double small roses of delicious fragrance. The only sweet-scented double crab. 4 to 5 feet. Price, not postpaid: Each, $\$ 2.00$.

RUSSIAN OLIVE (AB). 5 to 6 feet. A very hardy and handsome species that in some sections forms a small tree, 8 to 12 feet bigh. The leaves are particularly handsome, willowlike and a rich silvery white. The flowers are small, golden jellow and very fragrant, followed by yellow fruits, very fragrant, followed by yellow fruits, Which are covered with silvery scales. $\$ 1.00$; per $10, \$ 9.00$.

GOLDEN RCSSIAN WILLOW (B). At the present time one of the most planted of all willows and a very important tree, both from an ornamental and economical standpoint. It makes a round top tree of symmetrical form. One of its strongest ornamental features is the bright clear ornamental features is the bright clear golden sellow bark which offers a contrast
wherever used. Not postpaid: Each, 75c; wherever used $10, \$ 6.50$.

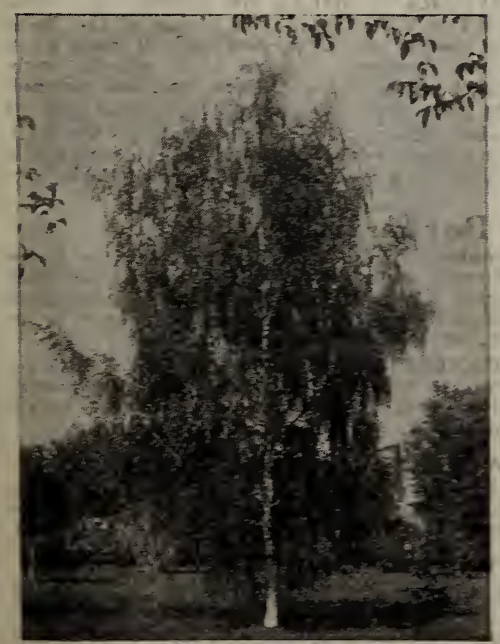

Cut-Leared Weeping Birch.
LARCH (Larix Europea). A lofty, rapid growing, pyramidal tree, with delicate light green foliage and drooping branches, with the charcteristics of an evergreen, except that it drops its foliage in the Fall. Very beautiful and fine for specimens on the lawn. 3 to 4 feet. $\$ 1.40$ each, not postpaid.

BLACK WALNUT. A splendid shade and ornamental tree and the best tree for Colorado. It should be planted more in this country. Because of its deep tap root, only small sizes should be set. 6 to 8 feet. $\$ 1.00$ each; per ten, $\$ 9.50$.

MOUNTAIN ASH (European) (B). Hardy tree; bead dense and regular, beautiful fernlike green foliage; covered from July tili Winter with clusters of bright, red berries. The combination of foliage and clustered fruits makes this one of the most striking and beautiful trees that grow. Not postpaid: Each, $\$ 1.00$; per 10, \$9.00.

SYCAMORE, AMERICAN (Platanus) (AB). Noble, upright growing tree, with spacious head and large deep green foliage. 6 to 8 feet. $\$ 1.50$ each.

OAK, RED (AB). A large native tree with deevly cut, bright green leaves which turn purplish crimson in Autumn. 5 to 6 feet. $\$ 2.00$ each.

SOFT or SILVER MAPLE (A). 6 to $8 \mathrm{ft}$. A hardy, rapid-growing native tree of large size. Valuable for proutucing a

NORWAY MAPLE (A). 6 to 8 feet. Native of Europe; a large, handsome tree, with broad, deep green shining foliage. Very desirable for street, park or lawns. The Norway Maple characteristically makes the roundest head; is colored the deepest, coolest green; and furnishes the densest shade of the entire list of good trees. Price, each, $\$ 1.75 ;$ per $10, \$ 15.00$, not postpaid.

SUGAR or HARD MAPLE (A). 6 to 8 feet. This tree is chieftain of its clan; straight, spreading, symmetrical, of grand proportions, often 40 feet in height, and longer lived than most men who plant it. It grows well in all except damp, soggy soils, and roots deeply, allowing grass to grow close to its trunk. Its bold leaves have very rich autumn tints of clear jellow and scarlet. Price, each, \$1.40; per 10, \$12.00, not postpaid.

WEIR'S CUT LEAVED SILVER MAPLE (AB). 6 to 8 feet. One of the best cut or dissected leaved trees, of rapid growth. Not postpaid: Each, \$1.50; per 10, \$13.50.

SCHWEDLER'S MAPLE (AB). The beautiful leaves attract attention at all seasons, but are especially fine in Spring when their gleaming red and purple contrasts brightly with the delicate green of other trees. In midsummer they are purplish green, in Autumn golden yellow. 5 to 6 feet. $\$ 3.00$ each.

BOLLEANA POPLAR (AB), 6 to 8 feet. Similar to Lombardy in habit, but broader, with leaves glossy green above, silvery beneath. Each, $\$ 1.50$; per $10, \$ 12.00$, not postpaid.

CAROLINA POPLAR (A). 8 to 10 feet. Unexcelled for quiek growth and effect. Its rapid growth gives an air of luxuriance to places where other trees appear starved. Showr and cheery from the constant movement of its glossy, silver-lined leaves, yet always casting a dense, cool shade. Not postpaid: Each, $75 \mathrm{c}$; per $10, \$ 6.50$.

CANADIAN POPLAR (AB). 6 to 8 feet. This poplar is related to the Cottonwrood, resembles it somewhat. Extremely hardy, is especially adapted to severe and exposed localities; more desired than the Cottonwood because it does not shed cotton and is more shapely in form and general growth. Not postpaid: Each, $\$ 1.00$; per 10, $\$ 9.00$.

LOMBARDY (AB). 8 to 10 feet. Pemarkable for its picturesque tall, spirelike form; desirable as quick growing street trees. Not pastpaid: Each, $\$ 1.00 ;$ per $10, \$ 9.00$.

SILVER LEAVED POPLAR. Large growing; leaves dark green on upper side, silver underneath. Each, $\$ 1.00 ; 10$ for $\$ 0.00$, not postpaid.

\section{Weeping Deciduous Trees}

CUT LEAVED WEEPING BIRCH (B). One of the most elegant of all weeping trees. Its tall, slender, yet rigrous Browth, with graceful drooping habit, silvery white bark and delicate cut leared foliage males it one of the most attractive trees. It is especially orna. mental. 5 to 6 feet. Price, $\$ 2.75$ each, not postpaid.

MULBERRY TREE (Weeping) (B). A graceful and beautiful hardy tree, forming a perfect umbrella shaped head, with long slender, willowy branches, drooping to the ground and gracefully swaying in the wind. Foliage small, lobed and of a beautiful fresh glossy green. One Jear heads, $\$ .75$ each, not postpaid.

WEEPING WILLOW (Niobe) (B). A handsome tree, slender leaves, green above, silvery beneath. The twigs and bark tinged dark red. 5 to 6 feet. $\$ 1.00$ each. 


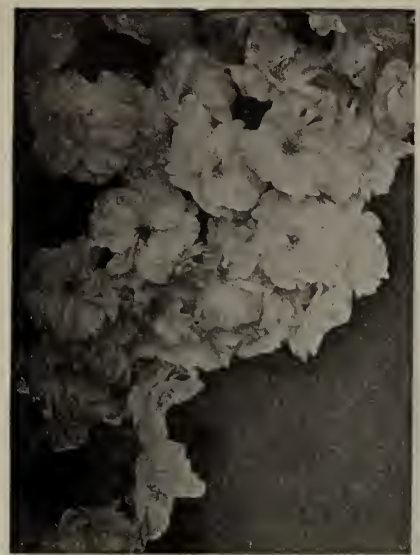

Flowering Almond.

\section{Elder - Sambucus}

Although the elders are attractive in flower and fruit, they are chiefly grown for their beautiful leaves, which make admirable fillers among other shrubs. Being rather tall growing and of robust habit, their use should be confined to backuse should be confined to back

AMERICAN ELDER (Canadensis) (L). Immense flat topped cymes of white flowers in early Summer, followed in August and September by luscious black fruits-the source of Mother's "Elderberry Pie." 3 to 4 feet. Each, 60 c, not prepaid.

CUT-LEAVED ELDER (Canadensis Acutifolia) (L). One of the best cutleaved shrubs. 3 to 4 feet. Each, 60c, not prepaid.

GOLDEN ELDER (S. Nigra Aurea) (L). Contrasted with other shrubs, the golden yellow leaves of this European elder gives heightened effects in tone and color. Flowers white in flat topped cymes. Grows naturally 10 to 15 feet but can be pruned into neat, compact little bush. Each, 60c, not prepaid.

\section{Feather Bush - Tamarix}

AMURENSIS (L). The hardiest variety. The loose, rose colored flowers are borne along its branches, the foliage is light and feathery. If cut back each Spring before the growth starts, the bush will be more graceful during the season. May be planted on moist ground as well as dry. 3 to 4 feet. Each, 50c, not prepaid.

\section{Golden Bell}

FORSYTHIA SUSPENSA (M). This splendid old shrub lights un the garden with glinting masses of yellow early in the Spring hefore the leaves appear. Has a drooping habit. 3 to 4 feet. Each, 60c, not prepaid.

\section{Honeysuckle - Lonicera}

The upright honeysuckles have bright and pretty fragrant flowers, followed by showy berries that last through the Fall. Make very desirable and attractive shrubs.

WHITE (M). Flowers blush white, 3 to 4 feet. Each, 60c, not prepaid.

ROSE or PINK (M). Deep rose pink flowers, 3 to 4 feet. Each, 65c, not prepaid.

RED (M). Blossoms are a very pronounced red; one of the best honeysuckles. 3 to 4 feet. Each, 65c, not prepaid.

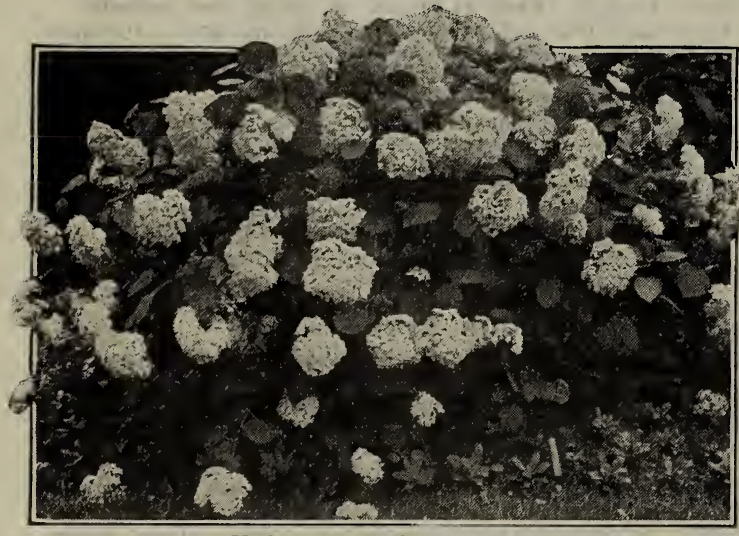

Hydrangea-Hills of Snow.
Flowering Almond

ALMOND (M). Spring flowering shrubs, blooming very gaily beAle leaves appear. Their growth is dwarf, bushy, and com pact; slender branched; when in bloom completely hidden by beautiful, double flowers of rose or white, snuggling tight to the twigs

\section{Butterfly Bush}

BUDDLEIA (Butterfly Bush) (S). A most beautiful shrub that produces of beautiful lilac colored flowers. It is a rapid grower and will leaves or manure, to insure a heavier growth the next season. It will bloom from June until frost. Extra strong plants. 50c each, not prepaid.

\section{Dogwood}

CORNUS SIBIRICA ALBA (M). Red stemmed. Clusters of fine white flowers, succeeded by a fall crop of ornamental berries; stem

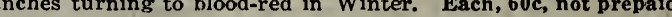

CORNUS STOLONIFERA, LUTEA (Flaviramea), (M). Yellow stemmed. Clusters of white flowers, stems, and branches are yellow. Each, 60c, not prepaid.

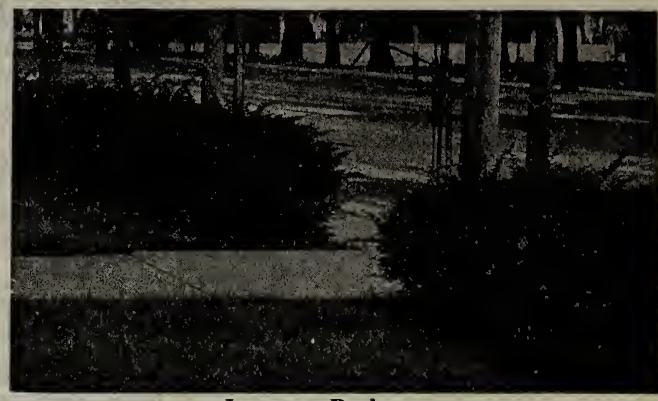

Japanese Barberry.

\section{Rose of Sharon}

HIBISCUS ; ALTHEA (S). One of the best known shrubs with handme plain and varie fol foliage bearing large single and double flowers in red, pink, and white in August and September. They are very hardy, easily cultivated and will bloom until their growth is cut off by frost. 3 to 4 feet. Each, $60 \mathrm{c}$, not prepaid.

\section{Hydrangea}

ARBORESCENS GRANDIFLORA or HILLS OF SNOW (S). This hardy A merican shrub grows 4 to 6 feet high and is one of the finest of this class of plants. The blooms are of largest size, of pure snow white and the foliage is finely finished. Blooms after all the early hrubs, from June until August. 2 to 3 feet. Each, 80c, not prepaid.

PANICULATA GRANDIFLORA (S). A good one to follow Hills of Snow, blooming profusely when other shrubs are failing in the Fall Blossoms open white, assuming rose and bronze tints on the sunny side Blossoms open white, assuming rose and bronze tints on the sunny side
and drooping gracefully of their own weight. 2 to 3 feet. Each, 80c, not prepaid.

\section{Barberry}

JAPANESE (Berberis Thunbergi) (D). A very popular low hedge plant of great hardiness : flowers followed by bright red berries that remain on plant until February. Foliage small dark green, turning to brilliant colors in Fall. Effective for use in edging shrubbery or in masses. $11 / 2$ to 2 feet. Each, 50c; 10 for $\$ 4.00$, not prepaid.

NEW RED-LEAVED JAPANESE BARBERRY. Similar in all repects to the green-leaved, but the foliage is of a rich, lustrous, bronzy red. It should be planted in a sunny exposure to bring out and retain its full red color. $11 / 2$ feet to 2 feet. $\$ 2.00$ each, not prepaid.

\section{Flowering Quince}

(Pyrus Japonica) (S). Very ornamental in early Spring, as its bright scarlet flowers completely cover the branches before the leaves are formed. Makes a good hedge. 2 to 3 feet. Each, 75c, not prepaid.

\section{Flowering Plum}

PURPLE-LEAVED (Pissardi). A small treelike shrub. The young branches are a dark purple; the lenves when young are lustrous crimbranchanging to dark purple th early Spring yofore the leaves unfold the tree is covered with flowers. Each, $\$ 1.00 ; 10$ for $\$ 8.00$, not prepaid. 


\section{Lilacs}

LILAC, COMMON PURPLE (Syringa Vulgaris) (M). The lilac is familiar to everyone, with its fine, heart-shaped foliage and splendid panicles of typical lilac flowers, which are of delightful fragrance and borne in magnificent clusters in May. It is still a favorite, in spite of the newer hybrids, of which it is the parent. Each, 75 , not prepaid

LILAC, COMMON WHITE (Syringa Vulgaris Alba) (M). Similar to the former, with pure white, very fragrant flowers and handsome foliage. Each. 75c, not prepaid.

LILAC, PERSIAN (Syringa Persica). This variety has smaller leaves than the common lilac. Its branches are slender and straight; the bright purple flowers are borne in loose panicles in a fine graceful form. 3 to 4 purple flowers are borne in $\$ 1.00$ each, not prepaid.

LILAC, HUNGARIAN (Syringa Josikaea). A fine distinct species of treelike stowth, with dark shining leaves and purple flowers. It blooms a month later, after all other lilacs are done blooming. Esteemed for its fine babits and foliage. 2 to 3 feet. $\$ 1.00$ each, not prepaid.

\section{Shrub Roses}

The roses we mention here grow too large to be planted with other bush roses and should be used only in connection with shrubbery or as specimens on lawns. Their beautiful blooms, ornamental foliage, bright berries, brilliant autumn colors and picturesque habit of growth make them very de sirable for every garden of ang size.

HUGONIS (Chinese Briar). A striking attractive new shrub, with clean healthy foliage of the briar tspe. When in bloom it is a shimmering mound of gold and very fragrant. A most decorative shrub from early Spring until late in Fall. $75 \mathrm{c}$ each.

F. J. GROOTENDORST. This is a Polyantha-Rugosa and new in its class. It has continuous blooming qualities, is of rugged hardy growth, with foliage shing and leathery. The blooms come in clusters of a rich, red color from early Summer until Fall. 65c esch.

ROSA RUBIGINOSA (English arching branches. Bright pink single flowers, followed by red berries gle flowers, followed by red berries that are retained all Winter. Foliage and flowers both have a rich, paid.

HANSA. Valuable for its great bardiness and vigor, flowers lange and double, of a reddish violet color, foliage always free from insect foliage always
pests. $65 \mathrm{e}$ each.

\section{Snowball}

VIBLRNUM OPULIS STERILE. A grand hardy shrub. The flowers ppear in numerous compact balls in the Spring. Well known and justly popular. 3 to 4 feet. $75 \mathrm{c}$ each, not prepaid.

VIBLRNCM DENTATUM (L) A perfect upright growing shrab. with heart-shaped leaves, bright green in Summer, changing later to a rich purple and red. The handcome creamy-white flowers are fol owed by blue-black berries. 3 to 4 feet. $75 \mathrm{c}$ each, not postpaid.

VIBURNUM OPULES (High Bush Cranberry) (L). The well known variety in old gardens. Grows 8 to 10 feet tall, bearing its alls of white flowers in great pro fusion in Mas and June, followed by scarlet fruits in clusters. 4 feet. $75 \mathrm{c}$ each, not postpaid.

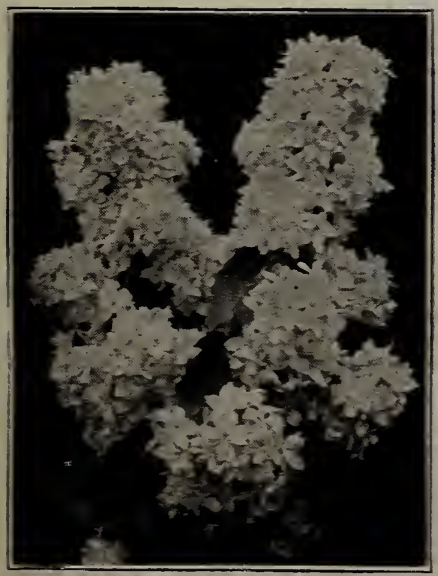

Lilac.

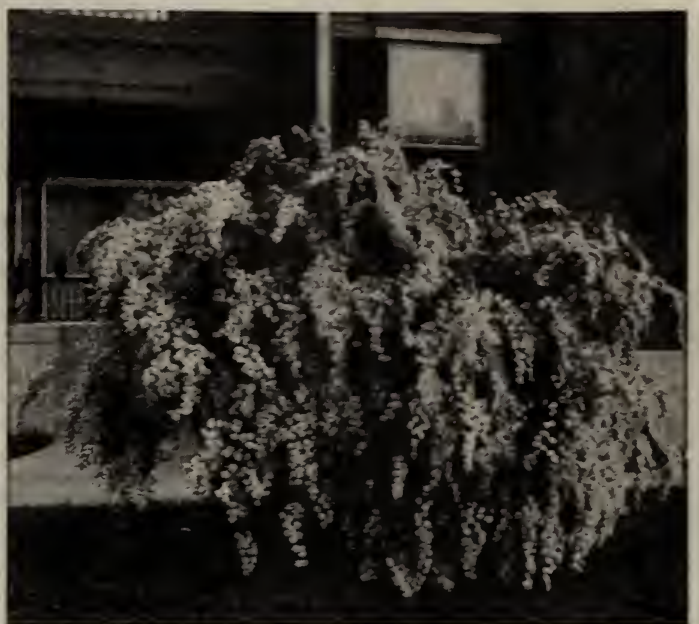

Spirea Van Houttei.

\section{Mock Orange}

MOCK ORANGE (Philadelphus Coronarius) (L). The Mock Orange is undoubtedly one of the best known and most popular shrubs, and, in spite of the great number of new plants which have been introduced, the old Philadelphus holds its own and more freely than ever. It is also known as Srringa in some localities. The shrubs are nsually tall, vigorous orous grower, with large foliage and fowers, and so ar Their flowers are very sweet-scented, milk-white, in most Their flowers are very sweet-scented, milk-white, in most
cases, and beautiful for cutting. Each, 65c, not prepaid.

\section{Kerria}

KERRIA JAPONICA (Japan Cochorus) (S). A handsome, green-leaved shrub, growing 4 to 5 feet tall.Graceful slender. drooping branches, painted with a wealth of rich dark yellow flowers in June, and to some extent all Summer. 2 to 3 feet. $85 \mathrm{c}$ each, not postpaid.

\section{Snowberry}

SYMPHORICARPOS RACEMOSU'S (White Snowberry) (S). Inconspicuous rose-colored flowers in June and July followed by large clusters of milk-white fruits which remain far irto the Winter. Each, 65c, not prepaid.

SYMPHORICARPOS VULGARIS (Indian Currant Coralberry) (S). Similar to the White Snowberry excep that its fruits are red, and that the smaller, red berrie cluster in thick ropes about the weighed-down stems. Each, $63 \mathrm{c}$, not prepaid.

\section{Sweet Scented Shrub}

Weigela.

\section{Spirea}

All of the spireas bloom with a riotous extravagance which makes them quite striking. Their individual style, color, and habits of Their individual sty growth differ so markedly that a collection of and still avoid the monotony of repetition.

ANTHONY WATERER. Dwarf, bushy, spreading iype, with large, deep red flowers. Blooms freely throughout the Summer until late in Fall. Fine for border or foundation planting. Each, 80c, not prepaid.

BILLIARDI. A strong grower; dull green foliage, dense panicles of bright pink flowers. Blooms during July and August and occasion. ally during the Fall. Each, 65 , not prepaid.

THUNBERGI. This Japanese species forms a dense fluffy bush, 3 to 5 feet high, with feathery foliage of yellowish green, changing in Autumn to bright red and orange. Flowers borne the entire length of the stem. One of the earliest to bloom. $60 \mathrm{c}$ each, not prepaid.

PRUNIFOLIA, TRUE BRIDAL WREATH (M). Beautiful white flowers, double and very profuse Foliage scarlet in Autumn. Each, $75 \mathrm{c}$, not prepaid.

VAN HOUTTEI (M). This is one of the finest ornamental shrubs in our whole collection, and much used in all good landscape work. Its branches droop with singular grace under their white burden of flowers in late under their white burden of
Spring. Each, 50c, not prepaid
This is one of the most desirable shrubs. The wood is fragrant. Flowers are of a rare chocolate color, having an exquisite pineapple fragrance. They bloom in June and throug

\section{Sumac}

Nothing will make a more attractive corne in the garden than a large clump of Sumac. The foliage is very graceful, on some varieties fernlike, and every lover of nature thrills at the gorgeous color display of its foliage in Autumn.

RHL'S GLABRA LACINIATA (S). A variety with deepls cut fernlike foliage which torn 4 feet. 65 each, not prepaid.

STAGHORX SUMAC (Rhus Typhina) (L) A large shrub or trea brilliant foliage and scarlet fruit in Autumn. 3 to 4 feet. Each, $75 c$, not prepaid.

\section{Weigela}

Beautiful shrubs that bloom in May, June, and Juls. The flowers are produced in so great profusion as to almost entirely hide the foliage.

DIERVILLA (Eva Rathke) (M). A charming new weigela; flowers brilliant crimson; a beautiful, distinct, clear shade. 2 to 3 feet. Each, $90 \mathrm{c}$, not prepaid.

ROSEA VARIEGATED (S). An exceedngly pretty rariety, the variegation being very distinct. 3 to 4 feet. Each, 90c, not prepaid. 


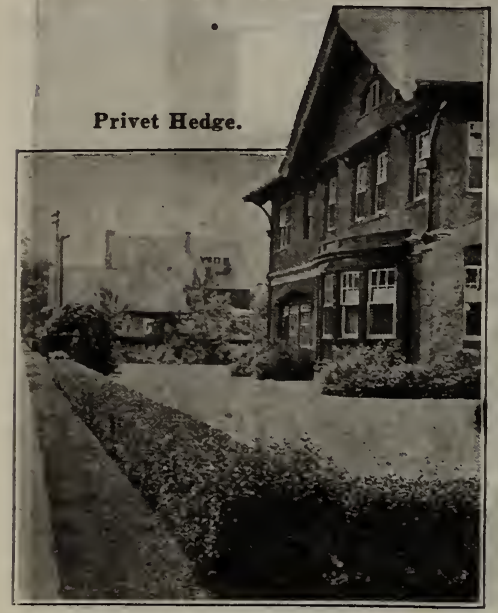

\section{Privet - Ligustrum}

Besides being one of our best hedge plants, various species of privet form interesting groups on the lawn.

They are almost evergreen; of dense compact habit. The flowers are fragrant, and are fllowed by pretty sprays of different colored berries.

AMOOR RIVER NORTH (L. Amurense) (M). Of similar form and habit to the California type, not so shiny, but reputed to be hardier. 2 to 3 feet. Per 10, \$2.00; per 100, $\$ 16.00$, not prepaid.

IBOTA (Chinese Privet) (M). Spreading and tall growing, the hardiest of the group Color grayish green, fruits black. 2 to 3 feet. Per 10, $\$ 2.00$; per 100, $\$ 16.00$, not prepaid.

IBOLIUM. This is a cross between Ibota and California Privet. The foliage resembles that of California, but Ibolium is much hardier, more branching and more spreading in growth It drops its foliage completely in Winter. Very popular privet. 18 to 24 inches. Per 10, \$2.00; per 100, \$15.00, not prepaid.

VULGARIS (English Privet). Grayish green leaves, white flowers and black fruit. Very hardy. $1 \frac{1}{2}$ to 2 feet. Per $10, \$ 2.00$; per $100, \$ 16.00$, not prepaid.

\section{HARDY CLIMBING VINES}

Plant more vines and plenty of them. There is hardly anything that will add so much attractiveness to the home as some well selected vines. They give an air of homelike seclusion, which is very pleasing. The following list embodies all popular varieties for all purposes.

\section{Ivy}

AMERICAN IVY; VIRGINIA CREEPER; WOODBINE. Fine for covering porches, verandas or trunks of trees. Very popular because it is a very hardy and rapid grower. It must have some kind of netting or framework on which to cling. Price, 2-year-old: Each, 35c; 5 for $\$ 1.50$, postpaid.

ENGELMANNI. This is the most satisfactory for our western country as it is very hardy; a rapid grower; more beautiful than the American Ivy; it requires no support on such surfaces as stucco walls or rough brick but on very smooth surfaces it does not cling. Price, 2-year-old roots: Each, $35 \mathrm{c} ; 5$ for $\$ 1.50$, postpaid.

BOSTON IVY. This is the variety that clings tightly to all surfaces whether smooth or rough. Leaves are deep green, smaller than the other ivies; however, it is not so popular in our western country as it grows very slowly in this climate. Price, 2-year-old plants: Each, 75c; 5 for $\$ 3.00$, postpaid.

\section{Clematis}

The finer varieties of clematis are today the most showy and effective of all the handy climbing vines known, so far as richness of color and elegance of form of flower is concerned. Their exceedingly rapid growth makes them very valuable for pillars and trellises, pegged down for rockork, old trees, and stumps.

JACKMANI. The flowers, when fully expanded, measure 5 to 6 inches in diameter, of intense violet purplish color, with a rich velvety appearance; bloom continuously until frost. Each, $85 \mathrm{c}$

PANICULATA (Sweet-Scented Japan.) Are of very rapid growth, quickly covering trellises and arbors with handsome, clean, glossy foliage. The flowers are medium sized, white in color, very fragrant and of a shiny appearance, blooming in August and September. Each, 50c.

MADAME EDOUARD ANDRE. Flowers large, of a beautiful velvety red, very free flowering and a continuous bloomer. Each, 85 c.

COCCINEA. A native southern species; hardy; flowers small, bright scarlet. A very interesting plant. $50 \mathrm{c}$ each, not postpaid.

RAMONA. A strong rampant grower and very hardy. It is a free and perpetual blooming variety. The color of the flower is deep sky blue, and the largest of any kind. Each, 85c.

\section{Honeysuckle - Lonicera}

Their vining qualities are all that can be desired, but the delightful fragrance of their flowers makes the strongest bid for favor. The honeysuckle perfume is loved throughout the world.

BELGICA (Monthly Fragrant). One of the prettiest, with numerous sprays of red and yellow. Each, 60c; per 10, \$5.50.

HALLIANA. Color, an intermingling of white and yellow; extremely fragrant and most satisfactory. Each, 50c; per 10, \$4.50.

SEMPERVIRENS (Scarlet Trumpet Honeysuckle). Trumpet-shaped flowers of bright searlet. Each, 65c; per 10, $\$ 6.00$.

\section{Assorted Vines}

CHINESE MATRIMONY VINE (Lycium Chinense). A general utility hardy climbing vine that

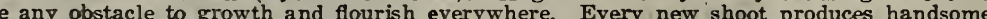

CIN N AMON VINE. Well known hardy climber, quick grower, with glossy heart-shaped leaves and sweet-scented flowers. $15 \mathrm{c}$ each ; $\$ 1.50$ per doz., postpaid.

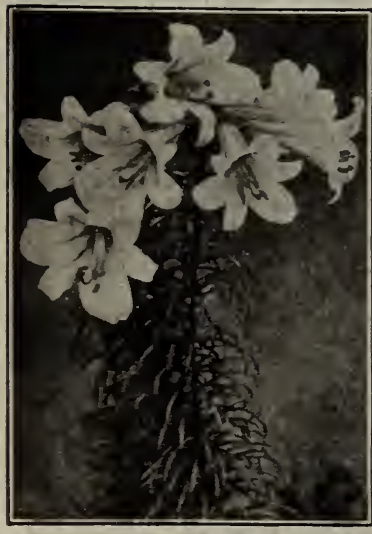

Regal Lily.

\section{flowers and later a prodigious crop of scarlet berries nearly an inch long. Each, 50c; 10 for $\$ 4.00$.}

JAPANESE KUDZU VINE (Pueraria Thunbergiana). The fastest growing vine; when established making 12 to 14 inches a day. The rosy purple, pea-shaped flowers are borne in racemes in August. Large plants. Each, $40 \mathrm{c} ; 10$ for $\$ 3.00$.

TRUMPET VINE (Bignonia Radicans). A splendid, hardy climbing plant, with large, trumpet-shaped, scarlet flowers in August. Two-year-old: Each, 40c; per 10, \$3.50.

WISTERIA (Sinensis). Chinese Purple. The long, twining branches bear great sprays of foliage, while its charming flowers $s$ way with every passing breeze. Each, $75 \mathrm{c} ; 10$ for $\$ 6.50$.

WISTERIA (Sinensis Alba). Of similar habit to Sinensis, but with pure white flowers. Each, 75c; 10 for $\$ 6.50$.

MADEIRA VINE. A beautiful, rapid growing vine, with dense foliage, white, fragrant flowers. A hardy plant if protected during the Winter. Strong tubers, $15 \mathrm{c}$ each; $\$ 1.50$ per doz., postpaid.

\section{HARDY LILIES}

LILY-OF-THE-VALLEY. This highly perfumed, delicate and refined looking lily should be given a space in every garden. It does best in a shady corner and spreads rapidly. Every year you find more plants. They show early in the Spring and are one of the first to bloom. It is very hardy and needs attention in the Fall to carry them through the Winter. 6 pips for $40 \mathrm{c} ; 12$ for $70 \mathrm{c} ; 100$ for $\$ 6.00$.

TIGER LILY. Large flowers of orange color, spotted black, often 2 to 3 blooms to the stem; grows about 4 to 5 feet high and makes a dandy background. Should be planted about 1 foot apart. Each, 20e; dozen, \$2.00.

LEMON LILY. A pretty plant with long narrow leaves and flower stalks 2 to 3 feet high. These are crowned in June with delightfully fragrant, beautiful lemon-colored flowers, 3 to 4 inches in diameter. A very popular variety. Makes a magnificent display when planted in a large bed. Each, 25c; dozen, \$2.50.

LILIUM AURATUM (Gold-Banded Lily of Japan). Flowers 8 to 10 inches in diameter. Color white, thickly studded with chocolate crimson spots and a bright golden band through the center of each petal. Good sized bulbs, 40c each.

LILIUM REGALE or MYRIOPHYLLUM. A new lily of rare beauty from northwestern China. The flowers are white, slightly suffused with pink, canary yellow at center, and very fragrant. Large bulbs, 50 c each, postpaid. 


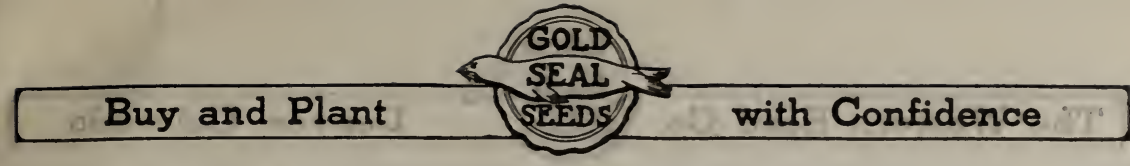

\section{Roses}

All the roses we send out are No. 1, field-grown, healthy, two-year-old, and not grafted. These roses are ready to bloom the first season after planting. Should you receive your roses by Express or Mail and they appear dry and shriveled, which may be due to delay in transit, put them in a cool and moist place, cover them entirely about 6 or 8 inches deep for about 4 or 5 days, then dig them up and plant them in the proper place. You will find your roses have regained their good color and the bark is smooth and full. At no time after unpacking should the roots be exposed to the sun and wind. Place the roses in a bucket of water; it won't hurt if the plants are soaked thoroughly.

Roses are easily grown, but never plant them carelessly. Roses are sure to die unless you plant them in a hole that is large enough so as not to cramp the roots. Place the soil about the roots; add plenty of water and pack firmly. A little well-rotted manure, mixed with the manure, mixed with the soil, is very beneficial; don't expect roses that are
planted in April or May to start growing in a week or 10 days; give them at least 3 weeks to start. Provisions should be made for good drainage, if the location is not naturally drained.

The rose delights in an open air situation, unshaded by trees or buildings. All the types are very partial to clay types are very partial to clay ordinary soil, if enriched with well-rotted barnyard manure. After the plants have been

Gruss an Teplitz.

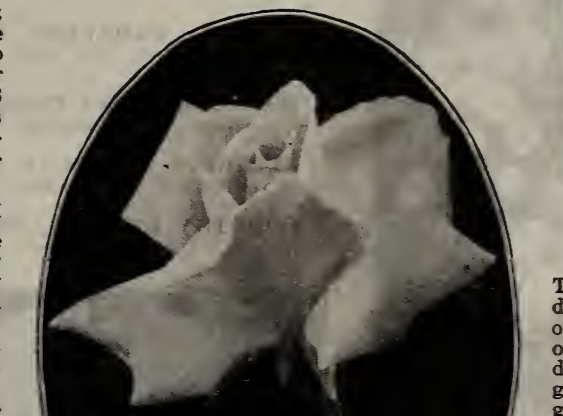
by frequent

The rose should be given plenty of water in the summer months when it is extemely hot and dry, eutting down the water supply in the Fall. An occasional soaking with weak manure water during the blooming season is most beneficial to all rarieties of roses.

H. P.-Denotes Hybrid Perpetual.

H. T.-Denotes Hybrid Tea.

WHITE KILLARNEY, H. T. A sport from Killarney; it is pure white in color, long in bud, of fine form. $60 \mathrm{c}$ each.

PINK KILLARNEY, H. T. Deep shell pink, long pointed buds with large flowers; very

I.A FRANCE, H. T. Bright satiny pink, with silver reflex. $60 \mathrm{e}$ each.

GENERAL SUPERIOR ARNOLD JANSSEN H. T. Light crimson or carmine red, blooms on stately stems, fragrant, and long lasting. A very strong, free flowering very strong, free flowering each.

GENERAL JACQUEMIVOT $\mathrm{P}$ let crimson; an old favorite and one of the best known roses in cultivation. $65 \mathrm{c}$

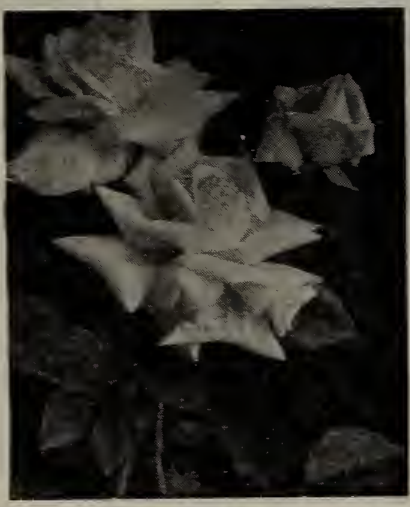

Los Angeles.

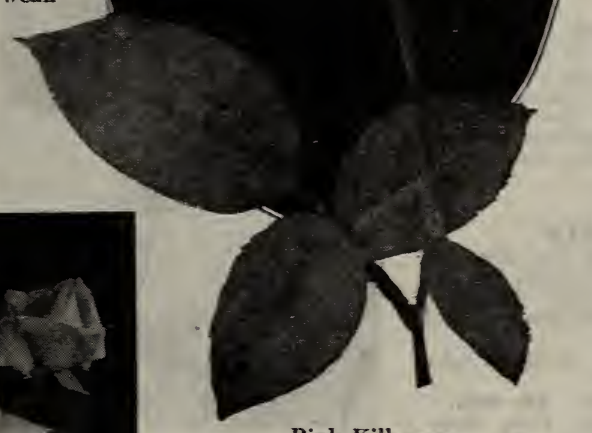

Pink Killarney.

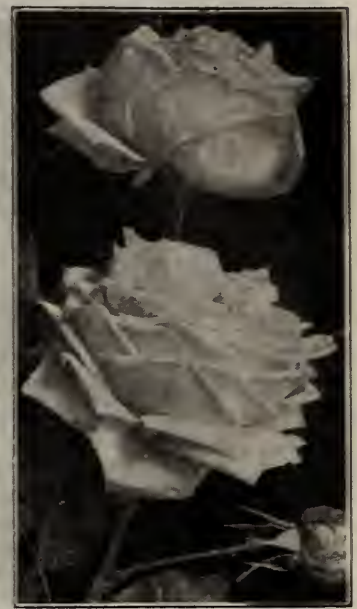

La France.

KAISERIN AUGUSTA VIC TORIA, H. T. This is a splen. did rose of a creamy white col. or. The buds are pointed, opening into a superb ful double flower of delightful fra. grance. Should be in every garden. $75 \mathrm{e}$ each.

GEORGE ARENDS, H. P Clear, brilliant pink, good bud
and perfect formed flower. Strong grower and in every way worthy. $65 \mathrm{e}$ each.

GRLSS AN TEPLITZ, H. T. Brightest scarlet crimson; growing freely and flowering in cold sections. 60e each.

OPHELIA (Golden), H. T. Rich apricot-yellow color. slightly paler at the edges. A very beautiful rose, and very popular. $75 \mathrm{e}$ each.

FRAU KARL DRUSCHKI, H. P. Pure snow white, long pree and constant bloomer. 6 c each.

BETTY, H. T. The flowers are deliciously fragrant of very large size full and beautiful. The exquisite color being copper, overspread with a beautiful golden yellow. $60 \mathrm{c}$ each.

RADIANCE. A great garden rose; large globular flowers; color brilliant rosy carmine, with rich pink tints; splendid grower, one of the best. Each, 65 c.

RED RADIANCE, H. T. The color is a splendid even shade of clear red, without a trace of any other color. It is a remarkable bloomer, being constantly in flower from early Spring until freezing weather. Extra hardy, prolific grower; one of the best outdoor weather. Extra hardy, prolific each.

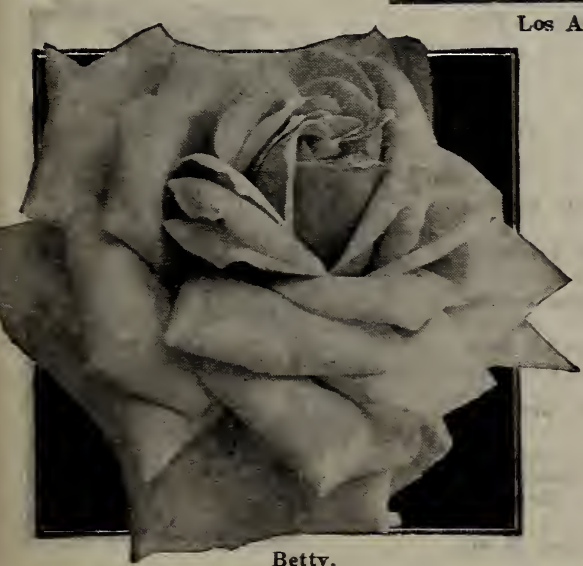

LOS ANGELES, H. T. One of the grandest all around roses of American origin ever put on the market; of vigorous growth, with long stemmed flowers of a luscious flame pink, toned with coral and shaded with gold at the base of the petals; buds are long and pointed. Each, 75c.

BLACK PRINCE, H. P. Deep crimson. Large, full, and globular. 60 c each.

CAPTAIN CHRISTY, H. P. Has foliage of rare beauty, dense and deep green in color. The very large, full flowers are of pale peach color, deepening towards the center to rosy crimson, and blooms almost the entire season. $60 \mathrm{c}$ each.

SUNBURST, H. T. Deep cadmium yellow, with orange sellow center; large, full, and beautiful form. $80 \mathrm{c}$ each.

AMERICAN BEAUTY, H. T. Too well known to need description; color rich red, passing to crimson. $65 \mathrm{c}$ each.

CAPT. HAYWARD, H. P. Of largest size. Color, glowing crimson, very bright and rich; about the best $H$. $P$. in its class. $60 \mathrm{c}$ each.

GENERAL MacARTHUR, H. T. Bright scarlet, large, full, and very free, erect branching habit and very perpetual. One of the finest and most fragrant roses grown. 60e each.

MADAME EDOUARD HERRIOT, H. T. Deep terra-cotta or reddish-copper; free and strong. The "Daily Mail" Rose. 80 each. 


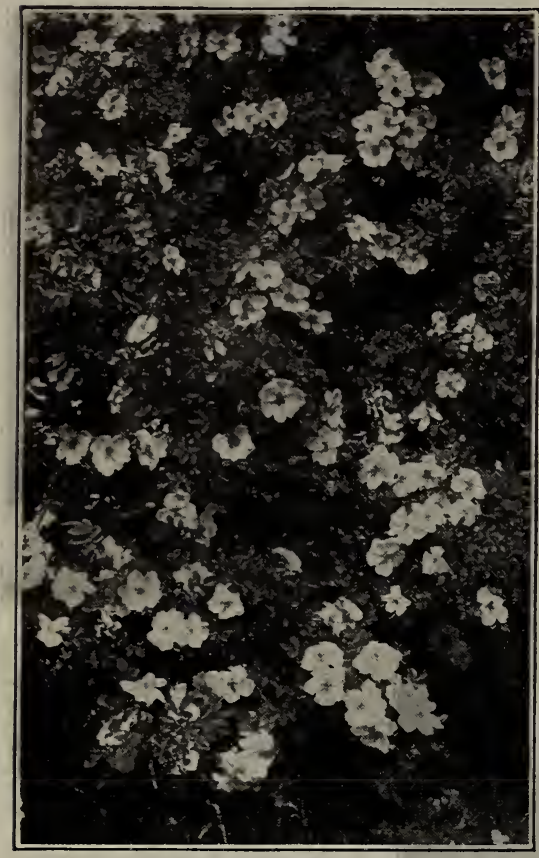

Rosa Hugonis.

PAUL'S SCARLET CLIMBER. The most brilliant rose known, because of its clear, vivid, brilliant rose known, because of its clear, vivid,
shining scarlet; in large, semi-double flowers, which remain long in good condition on the plants. The flowers never turn blue. A wonderful rose for pillars and trellises, strong grower, heavy foliage, free from insects and disease. Each, 75c.

\section{Baby Ramblers}

A type of rose derived from the climbing Polyantha, dwarf in habit. It blooms the entire Summer until late in the Fall. They are very useful for bedding, edging borders, and cemetery purposes.

BABY CRIMSON RAMBLER. Brilliant ruby red. $65 \mathrm{c}$ each.

BABY DORO'HY. Pure pink. 65c each. CATHERINE ZEIMET. White Baby Rambler. Snow white, double flowering. 65c each.

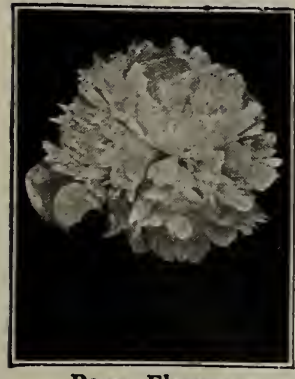

Rosea Elegans.

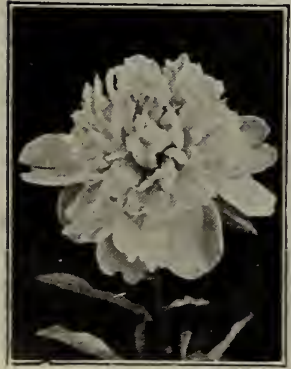

[64]

Edulis Superbe.

\section{ROSES-Continued}

HIS MAJESTY, H. P. Dark crimson shaded vermilion. Some class it as a Hybrid Tea. $60 \mathrm{c}$ each.

PAUL NEYRON, H. P. Deep rose, immense size; hardy, and vigorous. 60c each.

ULRICH BRUNNER, H. P. Cherry-red, very large and fine form; fragrant. 60c each.

CONRAD F. MEYER, H. P. This rose is classified by some as the best Hybrid Perpetual ever grown, free bloomer, large double, and cup-shaped, intense pink, very fragrant. 60c each.

$\left.\begin{array}{l}\text { F. J. GROOTENDORST } \\ \text { ROSA RUBIGINOSA } \\ \text { HANSA } \\ \text { HUGONIS }\end{array}\right\}$ Sce Page 61.

\section{Climbing Varieties}

CRIMSON RAMBLER. An old favorite, very hardy, of quick growth and very strong. Satisfaction sure. $60 \mathrm{c}$ each.

WHITE DOROTHY PERKINS. Same as the original Dorothy Perkins, except color is clear white. Fills long felt want for a hardy white climber. $60 \mathrm{c}$ each.

CLIMBING AMERICAN BEAUTY. Heavy strong grower, hardy everywhere; color, rich red fading to crimson. Very popular. $65 \mathrm{c}$ each.

DOROTHY PERKINS, PINK. Beautiful deep pink. Too well known for further description. One of our best climbers. 60c each.

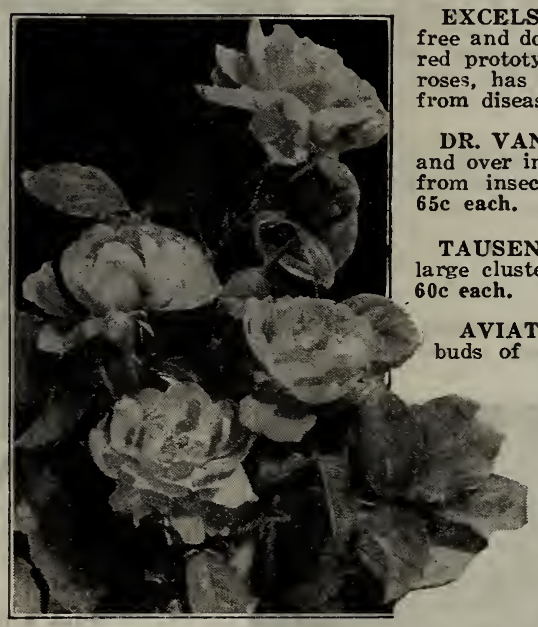

Paul's Scarlet Climber. each.
EXCELSA. A radiant, blood red cluster rose, as 年 clean foliage and proves always free rom disease. $60 \mathrm{c}$ each.

D. VAN FLEET. Flowers when open are 4 inches and over in diameter. It is absolutely hardy and free Color flesh pink. A very fine rose.

TAUSENDSCHOEN, Soft pink, flowering freely in The clusters; vigorous and almost free from thorns.

VIATEUR BLERIOT, H. W. Exquisite little fron-yellow, shaded apricot, opening to a lighter shade; of a delightful magnolia fragrance; blooms in clusters, thrifty growers, with a fine glossy foliage. Each. $65 \mathrm{c}$.

SHOWER OF GOLD, H. W. Deep golden yellow, very double, free and lasting; glossy bronze foliage. Each, 60c.

MARY WALLACE, H. W. Flowers are semi-double, well formed, very large, of a bright clear rose pink color, with salmon base, Each, 65c.

\section{PEONIES}

There is no other plant that will make such a magnificent display of rich colors and give as much satis faction in return for the trouble that you put in its cultivation. You should not be disappointed if the peonies do not ouite come up to expectations the first year, for the second and succeeding years will make up for this if it should so happen.

The culture of the peonies is very easy and it does not require any certain soil, either sandy or heavy will do. The earth must be spaded certain soil, either sandy or heavy will do. The earth must be spaded deep. A little manure mixed in would not hurt. After your ground is 1 to 2 inches. Then give them plenty of water for best results. The 1 to 2 inches. Then give them plenty of water for best

FAUST. Shell pink. Midseason.

ROSEA ELEGANS. Soft pink. Midseason.

RUBRA TRIUMPHANS. Dark red. Early midseason.

EDULIS SUPERBA. Rose pink, very early.

GENERAL McMAHON. Bright crimson.

DUKE OF WELLINGTON. Ivory white with creamy white center. Very large. Late.

OFFICINALIS RUBRA (Old Red). Flowers of a bright crimson, quite double, and globular. Very early and fine.

QUEEN VICTORIA. A good-sized flower; outside pure white, center creamy white; inner petals usually tipped carmine; early.

FESTIVA MAXIMA. Pure white center, prominently speckled with crimson; outer petals faint lilac white; extra large blooms, long stems; one of the finest and newest sorts; early.

Prices on above varieties, large healthy roots: Each, 50c; per ten, $\$ 4.00$, postpaid.

FELIX CROUSSE. Has large, globular flowers, solid and compactly built from edge to center, of a rich, brilliant, dazzling red. Exception-
ally fiery, bright and effective. None better. Late midseason. 75c each, ally fiery,

postpaid. postpaid.

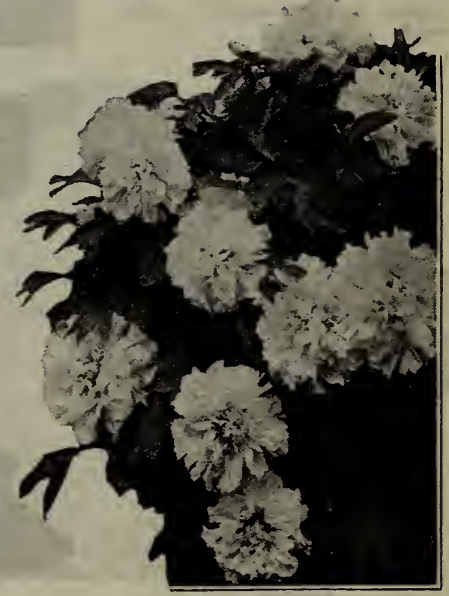

Festiva Maxima. 


\section{CANNAS}

In preparing the ground for the canna, earth should be maded at least 2 feet deep and plenty of stable manure mixed in The root must be set about 8 to 10 inches from the surface and 2 feet apart, and then with little attention, the plants will bloom heavily.

HUNGARIA. The best pink canna, very compact, almost dwarf, and of a very luxuriant growth. Leaves bluish green, never burn; flowers very large with immense petals; color purest La France pink. Each, 25c; doz., \$2.50.

KING HUMBERT. The greatest favorite today; scarlet flowers, bronze leaves. This remarkable Gold Medal canna has been the sensation of the last few years. Each, 20c; doz., \$2.25.

FLORENCE VAUGHAN. Bright, rich golden yellow, spotted with red; 4 feet. Each, 15c; doz., $\$ 1.50$.

EUREKA. Large white blossoms on strong stems, an early sort, blooming through the entire Summer. Straight beds of this sort are very popular; 4 feet. Each, 20c; doz., \$2.25.

ORANGE BEDDER. Green foliage. Color bright orange with just enough scarlet suffusion to intensify the dazzling mass of color. 4 feet. Each, 20c; per doz., \$2.25.

MRS. ALFRED CONARD. Exquisite salmon-pink flowers of the largest size, produced in fine spikes well above the foliage. 4 feet. Each, 20 c; per doz., $\$ 2.25$.

THE PRESIDENT. Flowers of immense size, with glowing scarlet color. Leaves rich green. 4 feet. Each, 20c; per dozen, \$2.25.

\section{CALADIUM - Elephant Ear}

A grand tropical looking plant, sometimes used for the center of the lawn when the southern or tropical appearance is wanted for the garden. No plant or flower could give the same satisfaction as the caladium. The leaves oftentimes grow very large, measuring 3 feet long and $11 / 2$ feet wide, attaining a height from 2 to 4 feet. Large selected bulbs. Each, 20 c; per doz., $\$ 2.25$.

\section{TUBEROSES}

Grown for their fragrant spikes of heavy waxen flowers. Below we are offering two of the most commonly grown, and both are old standards of the garden.

PEARL. Dwarf and double; white, and very fragrant.

VARIEGATED. Single, white; very early.

Price, either variety: Each, 10c; doz., $\$ 1.00$, postpaid.

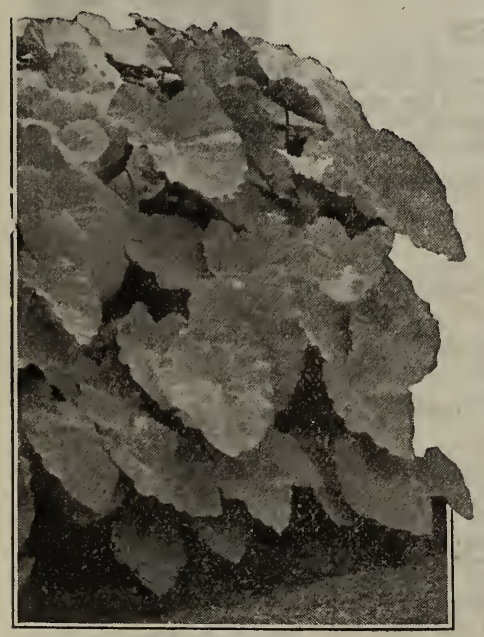

Caladium.

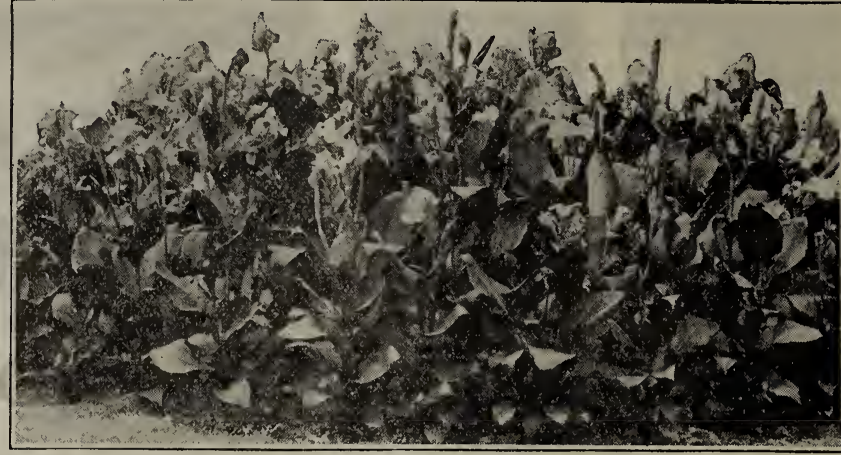

Cannas.

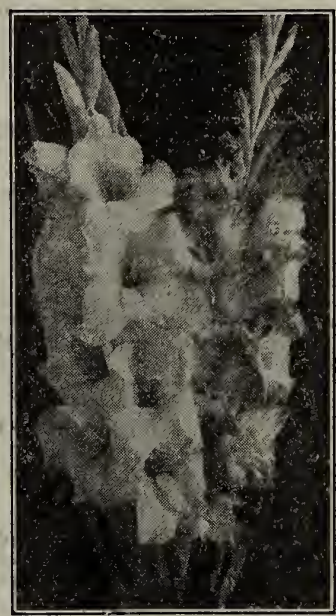

Gladiolus.

\section{GLADIOLI}

One of the most attractive of summer flowering bulbs is the gladiolus. A nice feature of this bulb is the culture; it does not require very much attention and only the res takes the usual amount of watering that is given any ordinary garden. In setting out the bulbs, try to select a sunny spot of fairly rich soil and spade deeply, then place your bulb in firmly 4 to 5 inches from the surface.

WILBRINCK. Fresh pink with creamy blotches, fine; extra early.

NIAGARA. Beautiful creamy yellow, primrose yellow throat.

PRINCE OF WALES. Delicate salmonrose of great value.

EARLY SUNRISE. Red, salmon-yellow throat, one of the earliest.

L'IMMACULEE. Pure white; medium size flowers.

LOUISE. Exquisite shade of bright lavender growing brighter toward center.

BARON HULOT. Deep rich purple.

E. J. SHAYLOR. A beautiful pure deep rose-pink.

FLORA. Fine golden yellow.

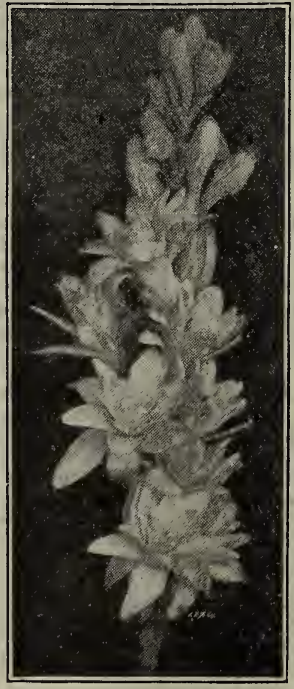

Tuberose.
ALICE TIPLADY. Bright orange, large open flowers, fine stems. HALLEY. Salmon-pink, very early.

MRS. FRANCIS KING. Vivid scarlet, long spikes.

MRS. FRANK PENDLETON. Bluish pink with brilliant carmine blotches.

Price, $10 \mathrm{c}$ each; any 3 for $25 \mathrm{c} ; 6$ for $45 \mathrm{c} ; 80 \mathrm{c}$ per doz., postpaid.

GLADIOLI IN MIXTURE, Special. A choice collection of many colors in mixture, suitable for massing. 40c per doz.; $\$ 2.75$ per 100 .

OUR OWN MIXTURE. Consisting of all good bulbs of different shades and a very good mixture. 30c per doz.; $\$ 2.25$ per 100 .

\section{SUMMER BEDDING PLANTS}

Many annuals that are used for bedding have to be started in the house or under glass in order to be ready in time for outdoor planting, so we have arranged to grow these and you may secure the plants ready to bloom. Many people do not have the time and patience to grow and care for the young plants and prefer to set the plants out and have flowers with less labor and care. We are listing below some of the popular varieties, which were grown from our best seed and are true in form and color. Ready about May 1st. LOBELIAS. $\$ 1.00$ per doz.; 5 doz., $\$ 4.50$, postpaid.

CALENDULAS. 10c each; $\$ 1.00$ per doz., postpaid.

CARNATION, Mixed Colors. 15c each; $\$ 1.50$ per doz., postpaid. PETUNIAS, Assorted Colors. 10c each; $\$ 1.00$ per doz, postpaid. VERBFNAS, Mixed Colors. 10c each; $\$ 1.00$ per doz., postpaid. ZINNIAS, Mixed Colors. $10 \mathrm{c}$ each; $\$ 1.00$ per doz., postpaid. SNAPDRAGONS, Assorted Colors. 10c each; $\$ 1.00$ per doz., postpaid.

MARIGOLD. $10 \mathrm{c}$ each; $\$ 1.00$ per doz., postpaid.

\section{Pansy Plants}

The plants offered by us are grown from our Gold Seal mixture and produce larger flowers than any variety grown. But remember, the pansy cannot and will not live up to expectations unless placed on strong ground that has been heavily fertilized with well rotted barnyard manure, and in most cases does best in a shady location. Always remember that pansies must have plenty of water. 1 doz. plants ready to bloom, 60c;5 doz., $\$ 2.50$, prepaid. Young plants, mixed colors, per $100, \$ 3.25$, not prepaid.

\section{Aster Plants}

CREGO GIANTS. The plants we offer are the best quality grown from the finest seed. We usually can offer them in separate colors-as crimson, pink, blue, lavender, purple or can furnish mixed colors. Price, postpaid, 60c per doz.; 5 doz., \$2.65. Ready about May first. 


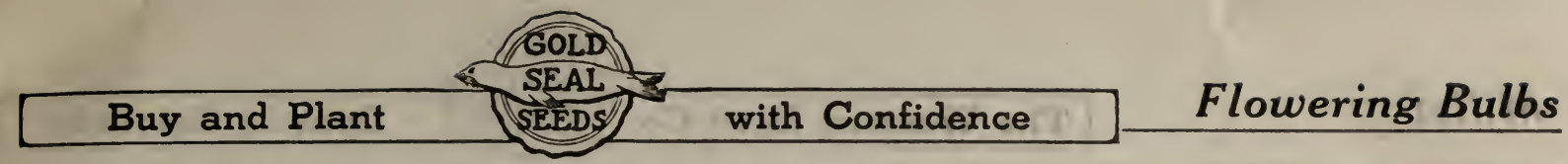

\section{Dahlias (Western Grown)}

Too many people think of dahlias as the old-fashioned, either red, yellow or white stiff flowers, but, each year there has been a great improvement in
dahlias, and the late creations are wonderful. Very few flowers can compare with them; such a wide range of color and shape, and the most pleasing thing about the dahlias is the never failing, wonderful results with such little care.

The sorts we are offering are of the best quality, strong and true to name In our lists we have included the late creations of such noted dahlia specialists as Judge Marean, Wilmore and Davis.

CULTURE. Pick a sunny spot if possible and spade well; do not use too much manure, for a small quantity goes far with the dahlia; then lay the root on its side about 4 inches from the surface. In covering, be sure to have the soil packed firmly about the tuber or roots; plant only when the soil is dry, then water sparingly.

Some flowers like dahlias, etc., wilt or fag soon after they are cut. Ordinary precaution is daily change of water. The best treatment for these is to pick them at the coolest hour, either late at night or early in the morning. Dip two or three inches of the stems in boiling water for two or three minutes and then place in cold water in a cold place. Do not hold flowers over the hot water, but dip the stems from the side, being careful not to heat the flowers. Another success is to dissolve an aspirin tablet in the vase.

\section{Peony-Flowered Dahlias}

GEISHA. Scarlet and gold, shaded to amber yellow. Each, 75c.

ISA. Fawn pink, changing with age to amber yellow. Each, 50c.

JESSIE SEAL. Clear old rose. Flowers very large. Each, \$1.00.

LE GRANDE LILAS. Royal purple. A wonderful dahlia. Each, 50c.

LAURA BARNES. Immense orange-red flowers. 50c each.

DIEMANT VAN BIJSTEIN. Rich lavender. Each, 50c.

QUEEN OF ROSES. Salmon-pink. Each, 75c.

RUTH NICHOLS. An immense flower of rich, dazzling red. Each, 50c.

SOUTH POLE. White Each, 50c.

SWEETHEART BOUQUET. Salmon-rose, shaded fawn. Each, 50c.

\section{Show Dahlias}

A. D. LIVONI. Rich pink, finely formed. Each, 20c. BON TON. Ball shaped, deep garnet red. Each, 20c.

GLOIRE DE LYON. Largest white dahlia in cultivation. Each, 20 c. BON TON. Ball shaped, deep varnet red. Each, 20c.

HELEN HOLLIS. Orange-scarlet. Each, 25c.

MAUDE ADAMS. Pure white; overlaid clear pink. Each, 25c. PURPLE GEM. Rich royal purple. Each, 20c.

W. W. RAWSON. White overlaid with delicate lavender. Each, 25c.

\section{Pompon Dahlias}

(These are the small variety-long lasting after cut). AMBER QUEEN. Rich clear amber. Each, 25c. CATHERINE. Primrose yellow. Each, 25c.

GIRLIE. Pure lilac. Each, 25c.

PRINCE CHARMING. Cream, heavily tipped purple. Each, 25c. JOE FETTE. A splendid new white. Each, 25 c. SUNBEAM. Crimson. Each, 25c.

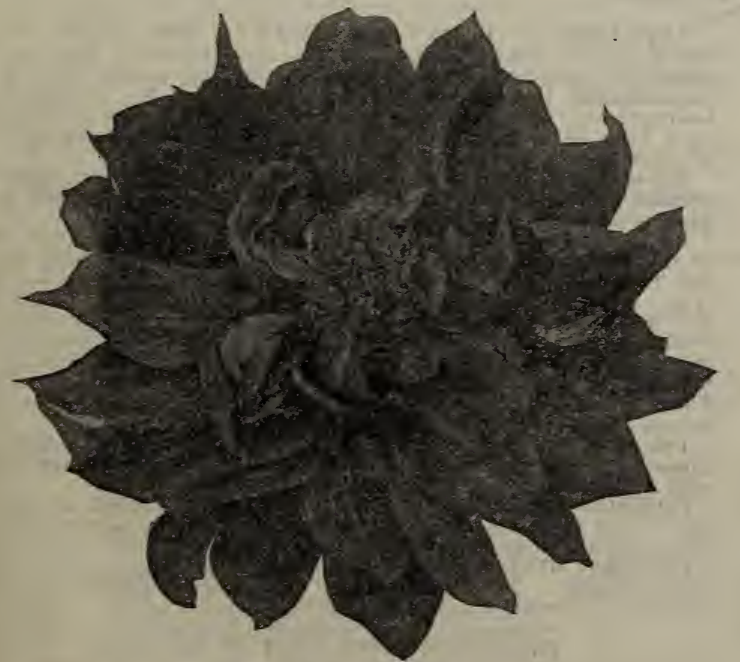

Peony-Flowered Dahlia.

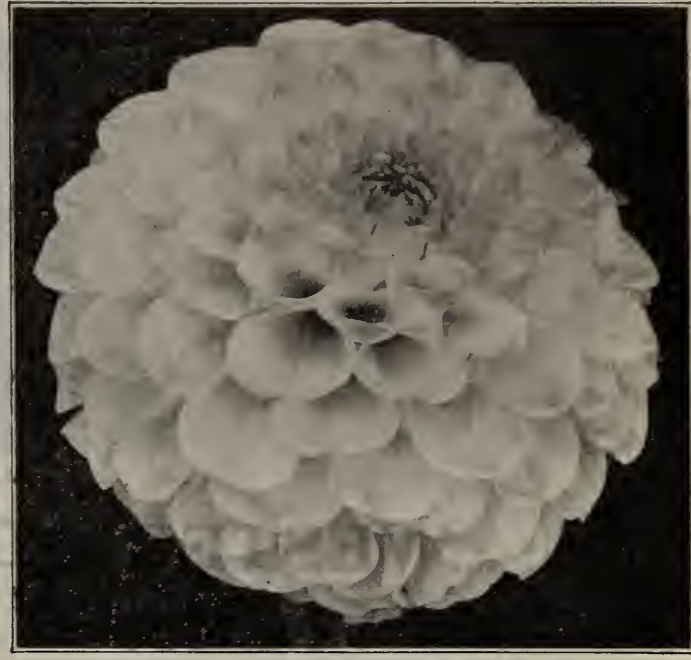

Show Dahlia.

\section{Decorative Dahlias}

AMUN RA. Copper and burnt orange. Each, $\$ 1.00$. BERCH VAN HEEMSTEDE. Clear rich yellow. Pkt., 25c. CHICOTA. Golden yellow of large size. Each, 50c. CROMSTOCK. Yellow; very good. Each, 50c. DELICE. Rosy pink of perfect form. Each, 25c. FRANCIS CLARKE. Almost black. Each, 25c.

JACK ROSE. Richest, velvety crimson dahlia ever grown. Each, 20c. JUDGE MAREAN (Judge Marean Creation). Salmon pink, orange and gold. Each, $\$ 1.00$.

GRAND MANITOU. Purple streaked and mottled with crimson. Each, $25 \mathrm{c}$.

LUCY DAVIS. Rich golden apricot. Each, 50c.

MABEL THATCHER (Judge Marean Creation). Pale yellow. Each, 50c.

MAID OF KENT. Intense scarlet variegated with pure white. Each, 20c.

MELROSE. Lilac-pink. Each, \$1.00.

MILLIONAIRE. Lavender-pink. Each, 50c.

MOONBEAM. Clear canary yellow. Each, 25c.

MONS. LeNORMAND. Bright yellow, striped and speckled with red. Each, 50c.

MRS. J. G. CASSATT. Mauve-pink. Each, 25c.

MRS. HARTONG. Light fawn suffused with pink. Each, 20c.

MRS. I. DE VER WARNER (Judge Marean Creation). Mauvepink. Each, 75c.

MRS. KARL SALBACH. Lavender-pink. Each, 50c.

PAUL BONYON. Gold and apricot. Each, 25c.

PINK JACK ROSE. Lavender with a beautiful tint of blue. Each, 20c.

PRIDE OF CALIFORNIA. Very large, vivid red. Each, 50c. QUEEN MARY. Shell pink. Each, $25 \mathrm{c}$

VENUS (Judge Marean Creation.) Creamy white suffused with lavender. Each, 50c.

\section{Cactus Dahlias}

ATTRACTION. Clear lilac-rose. Each, 50c. CHIPETA. Rich amaranth red. Each, $50 \mathrm{c}$

COUNTESS OF LONSDALE. An exquisite shade of rich salmon, apricot at base of petals. Each, 25c.

F. W. FELLOWS, Orange and scarlet. Each, 50c.

GEN. BULLER. Rich velvety crimson. Each, 20c.

GEO. WALTERS. Salmon-pink, suffused with old gold. Each, 50c. GOLDEN WEST. Old gold. Each, 50c.

KALIF. Nine inches in diameter; pure scarlet. Each, 50c.

MRS, DOUGLAS FLEMING, White Each, 50c

MRS. H. J. JONES. Bright red, tipped and edged with pure white Each, 25c.

MRS. W. E. ESTES. Largest and best snow-white dahlia. Each $\$ 1.00$.

RHEINKOENIG. Pure snowy white. Each, 25c.

THE GRIZZLY. Maroon. Each, $\$ 1.00$

WODAN. Salmon-rose, shading to old gold in center. Each, 50c. 


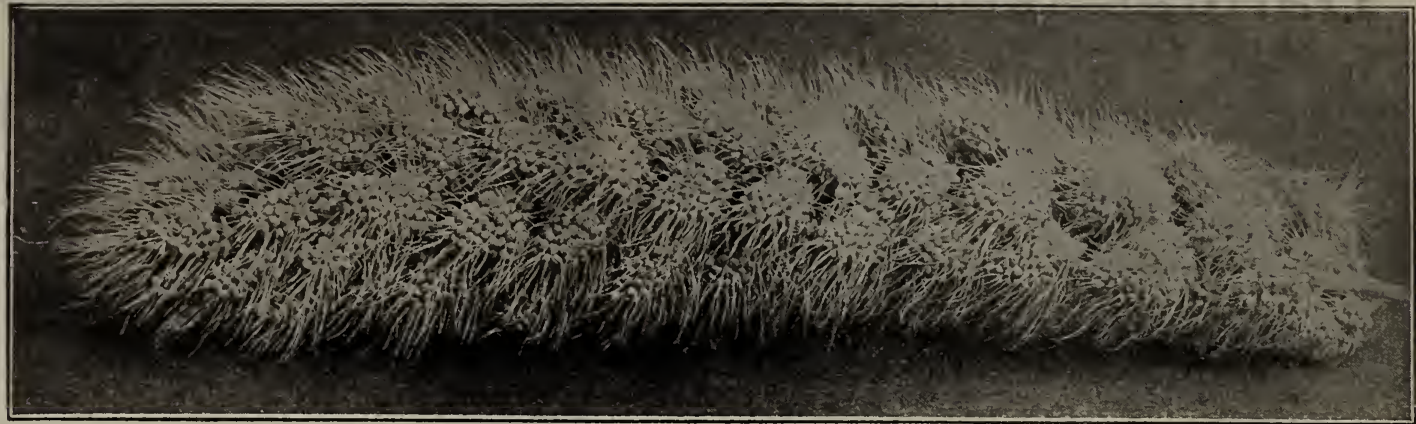

White Wonder Millet.

\section{WESTERN DRY LAND SEEDS Millet}

Millet is a wonderful forage and hay crop. It affords a quick, luxuriant growth of hay of good feeding value and requires no cultivation. It grows rank and tends to check weeds, and can be used in this way to good advantage in irrigated districts to clean up weedy fields. On account of the compact character of millet and the large amount of seed, a given bulk of millet hay will go farther than an equal amount of ordinary hay. Millets may be fed green or cured. The value of millets for late planting and emergency crops after others fail should not be overlooked. They can be planted late in July and still make considerable forage. Sow about thirty pounds to the acre.

WHITE WONDER MILLET. Two very striking features of White Wonder Millet are its extreme earliness and the size of the heads, which are from eight to eighteen inches long. The foliage is heavy the leaves broad and it is a very heavy producer, but the fodder cures readily. White Wonder Millet crowds Siberian for first place in earliness and $\mathrm{Bic}$ German for first place in productiveness, and has already taken the place of Common or Golden Millet. Laboratory tests show that White Wonder Millet contains a lower percentage of fiber than Hog Millet, is therefore more fattening, making the grain more desirable for feed. Prices, $1 \mathrm{lb}$., 10c; 6 lbs., 50c; 25 lbs., \$1.45, not prepaid. Please write for general quantity prices or subrait list of your requirements for special quotations.

SIBERIAN or RED RUSSIAN MILLET. This is a very fine variety, originally imported from Russia. It is earlier than German, is extremely hardy and withstands drought wonderfully. It produces big and the forage is quite palatable. Cattle like the hoy and many feeders claim that Siberian Millet is not so apt to cause abortion as other millets. The seed is borne plentifully and is readily purchased for poultry feeds. Prices, 1 lb., 10c; 6 lbs., 50c; 25 lbs., \$1.45, not prepaid. Please write for general quantity prices or submit list of your requirements for special quotations.

HOG or MANITOBA MILLET. This is the Proso Millet or Common Millet of the Old World, where it has been, since prehistoric times, an important grain crop for human food. In addition to the names Proso and Proso Millet, this crop is of ten called Hog Millet because of its frequent use as hog feed; Broom Corn Millet because of the head or panicle which somewhat resembles Broom Corn; and also Early Fortune, Manito and Dakota Millet.

Hog Millet seed has a slightly higher feeding value than oats and is eaten readily by all kinds of live stock and greatly relished by poultry. It is not as desirable for hay or forage as German or Siberian Millet and when desired for that purpose should be cut early. There is a good demand for the grain for feeding purposes. quantity prices or submit list of your requirements for special quotations.

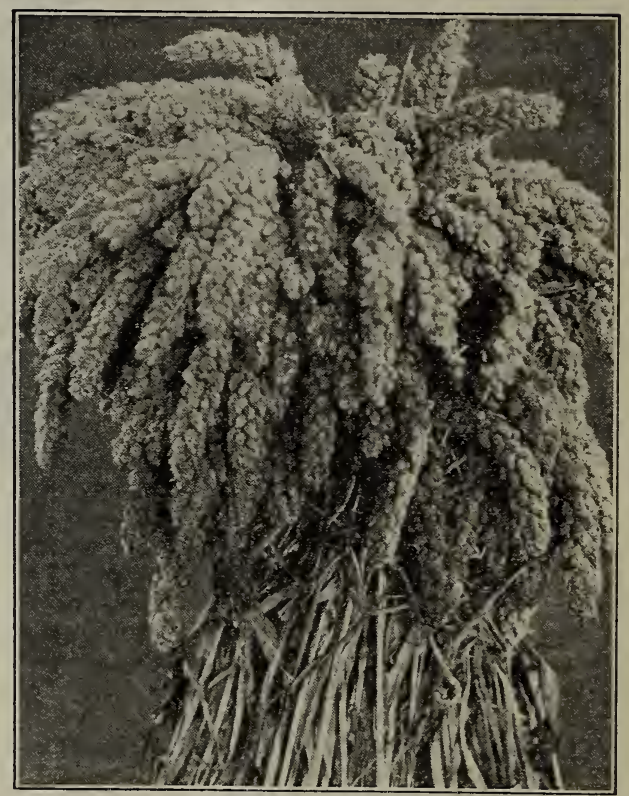

Big German Millet.

JAPANESE or BARNYARD MILLET. This variety is often calle reduce its qualities. It is the largest growing millet and is highly recommended for feeding dairy cattle. It does best on moist, rich lowlands and does not withstand drought well. Grows from six to nine feet tall. It makes good hay and is relished by all kinds of stock.

Prices, 1 lb., 15c; 5 lbs., 60c; 10 lbs., $\$ 1.00 ; 25$ lbs., $\$ 2.00$, not prepaid. Please write for general quantity prices or submit list of your requirements for special quotations.

BIG GERMAN MILLET. Above is an actual photograph, taken in the field, of Big German Millet-not Liberty nor Golden Milletbut True Big German. The seed we offer of this variety is true to type. Note the extremely long heads crowded full with myriad seeds. type. Note the extremely long heads crowded full with myriad seeds. See the small stems, luscious and highly palatable, clustered thick with fine narrow leaves that all live stock relish. Without a doubt this is the leading millet for hay and forage, for general feeding, for milk production. Be sure to get the genuine Big German Seed. This seed is higher in price than other

Prices, 1 lb., 10c; 6 lbs., 50c; 15 lbs., $\$ 1.00 ; 25$ lbs., $\$ 1.50$, not prepaid. Please write for general quantity prices or submit list of your requirements for special quotations.

COMMON MILLET. The seed of White Wonder Millet is now as low priced as the seed of Common but its worth is much oreater. Plant White Wonder instead of Common.

GOLDEN MILLET. This variety has also been supplanted by white Wonder. It is small seeded and a scant yielder and unlike the other varieties serves no distinct purpose.

Soak seed two hours in Formaldehyde. One pint to forty-five galHog or Manitoba Millet. lons of water. Copper Carbonate also effective. 


\section{WESTERN DRY LAND SEEDS}

In many sections of the West the rainfall is so slight and ground moisture so little that it is impossible to grow crops of the standard grains and grasses, and the acquirement of forage in these regions is a problem. On this page and those immediately following you can learn of many crops that have proven successful and have made farming profitable in the arid regions. But do not think that their gainful use ends with the dry
more prolific.

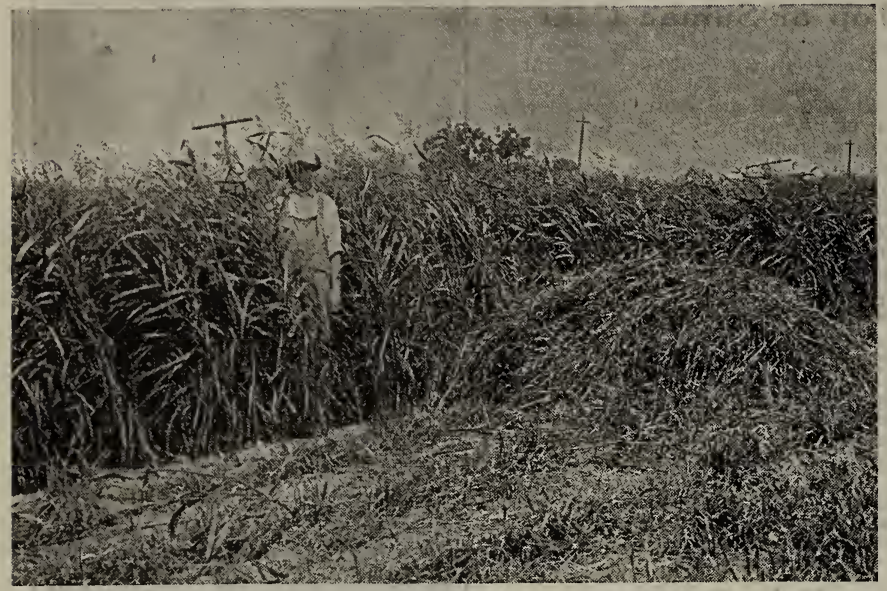

Sudan Grass.

\section{FETERITA}

Feterita is a native of Africa and is a leading variety in part of the Sudan region and has been grown in this country since 1906 . The heads are elongated and the seeds are bluish white and slightly larger than milo. The heads are always erect. Feterita appears to be able to withstand more drought than milo and sometimes produces a crop under conditions where milo fails. It is adapted to all purposes for "which the kaffirs and milos are used, and is among the earliest of the non-Saccharine sorghums. This might prove very valuable the earlest of the non-saccharine sorghums. This might prove very valuable as a catch crop after some earlier spring crop had failed. The grain is soft heavy growth, stools heavily, as many as six to eight shoots come from a single root. For hay, plant 20 to $30 \mathrm{lbs}$. to the acre, $8 \mathrm{lbs}$. for seed. Prices, $1 \mathrm{lb}$, $15 \mathrm{c} ; 5$ lbs., $50 \mathrm{c} ; 25 \mathrm{lbs}$., \$1.50, not prepaid. Please write for general quantity prices or submit list of your requirements for special quotations.

\section{SUNFLOWERS}

Those who have grown sunflowers in the arid regions, both for seed and silage, are very enthusiastic over the results obtained.

Sunflower silage is very pallatable. Cattle and sheep relish it, and stock will
S eat it as readily as they do corn silage. Some-
times in making the change from one to the other

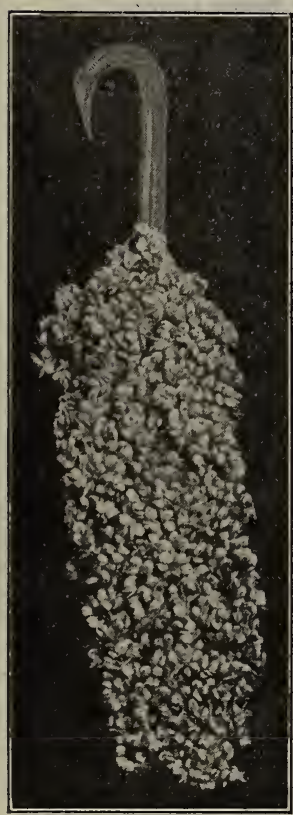

Dwarf Crookneck Milo [70]

\section{SUDAN GRASS}

Sudan Grass is a grain sorghum and is non-saccharine. However the straw is very palatable and is eagerly consumed by all kinds of livestock. It is very nutritious and has proven
to be a valuable feed for both milch cows and beef stock.

Although this wonderful forage crop is an annual and lacks an underground root system, yet it can be pastured to goor advantage and under favorable conditions two cuttings of hay may be obtained. It does not make permanent pasture. It has been found profitable to sow peas or soja beans with
Sudan Grass in sections where the rainfall is not too scant. Sudan Grass makes the heaviest yields on rich, loamy ground but has been grown successfully on every kind of soil from heavy clay to light sand. It is also looked upon with favor as a paying crop in districts where there is not with favor as a payir
a lack of moisture.

Plant when all danger of frost is over and the ground is thoroughly warm as the plant requires warmth and is not suited to altitudes above 7,000 feet. Sow ten to fifteen pounds per acre for hay and about five pounds for seed.

Cut for hay as soon as the grass is fully headed, with binder or mower as preferred. If planted in drills the crop can be conveniently handled with a corn binder. Northern grown seed is usually free from Johnson Grass. Prices, $1 \mathrm{lb}$. $15 \mathrm{c} ; 5$ lbs., 60c; 10 lbs., $\$ 1.00 ; 25$ lbs., $\$ 2.00$, not prepaid. Please write for general quantity prices or submit list of your requiremnts for special quotations.

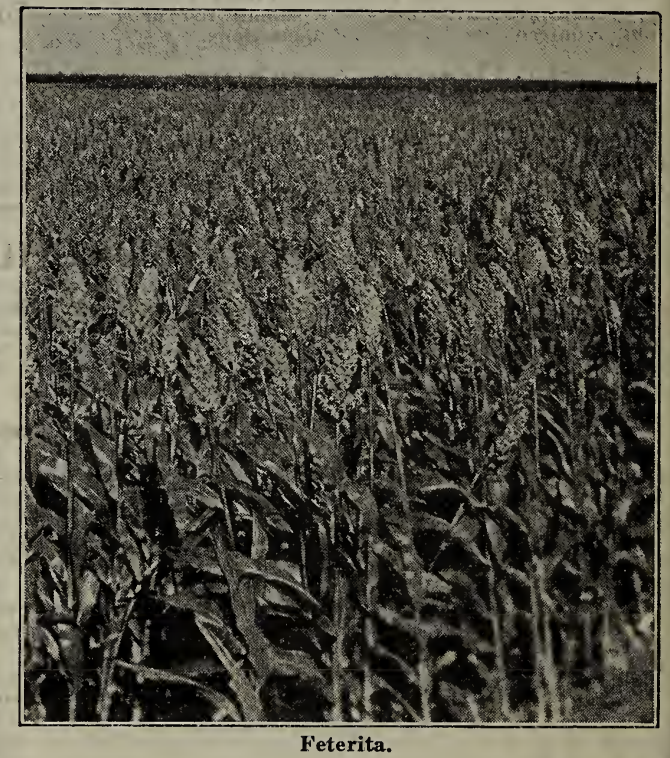
it takes a few days for stock to become accustomed
to sunflower Silage. Its feeding value is high. It has been found to produce as much milk and but terfat as corn.

Sunflowers may be sown earlier than corn as light frost does not injure them after the plants are up. But on the other hand they grow so rapidly, they may be sown as late as July 1st to 15 th and satisfactory silage obtained but not mature seed when sown so late. They are often used to replant when corn has failed. On dry land, sunflowers have yielded from 3 to 8.5 tons of silage per acre and 37.6 tons per acre is one of the largest yields reported. Plant close in the drills four to five inches a part, rows thirty to forty-two inches apart and cultivate and handle similar to corn. Five to six pounds per acre is usual amount sown. Prices, 1 lb., $25 \mathrm{c} ; 5$ lbs., $\$ 1.00 ; 10$ lbs., $\$ 1.80$, not prepaid. Please write for general quantity prices or submit list of your requirements for special quotations.

\section{MILO MAIZE}

Milo Maize stalks contain practically no juice and are, therefore, not so palatable as many of the other grain sorghums, but the grain is very valuable for feeds, especially in prepared poultry feeds, and is very fattening for poultry or cattle. Sow about ten to fifteen days later than the average time for planting corn or as soon as the soil has warmed up to a considerable extent and danger of frost is over. For grain or seed, sow 5 to $6 \mathrm{lbs}$. to the acre and 20 to $30 \mathrm{lbs}$. for hay.

DWARF YELLOW MILO. Sometimes called in local sections, Double Dwarf, averages three feet high and has the greatest adaption and is the most valuable for the production of grain.

WHITE MILO MAIZE. This variety has white seeds as the narne indicates. Does not yield as well as yellow maize and has no advantage over Dwarf Yellow Milo.

DWARF CROOKNECK MILO. The heads on this variety are pendant and the stalk arches to the heads like the curve on a walking cane. Grows about five feet high and produces grain abundantly. It is sometimes called Single Dwarf.

STANDARD MILO. Grows to a height of seven or eight feet, producing an abundance of fodder that makes excellent silage.

Prices, $1 \mathrm{lb}$., 10c; 6 lbs., 50c; 25 lbs., \$1.50, not prepaid. Please write for general quantity prices or submit list of your requirements for special quotations. 


\section{Western Clover Seed}

Clovers, being leguminous crops, are soil builders and are very useful for the farm or ranch. They are used for mixtures of hay and pasture as well as sown alone.
The different kinds grown in the West are fully described below. The best variety for your land can be readily chosen from these descriptions. We are offering only one grade in each variety and that is the best and purest obtainable.

\section{White Blossom Sweet Clover}

Melilotus Alba or White Blossom Sweet Clover, or Bokhara Clover, as it is also called, is a hardy biennial plant, erect and branching in growth. It starts up very early in the Spring and in its second year it reaches a height of from 5 to 12 feet.

early in the Spring and in its second year it reaches a height of from 5 to 12 feet. It seems to grow in all climates and with little regard to the character of the soil. It is found growing in gravel pits, heavy clay soils and sometimes in almost pure sand. And when planted in ground containing alkali, for one or two seasons, it leaves the
soil fertile. Not particular as to moisture, it stands more dry weather than alfalfa. It sends its roots to a great depth. It is a legume like red clover and cow peas, and, like these plants, has the faculty of extracting nitrogen from the air and storing it up in the roots, thus fertilizing the soil for the use of succeeding crops.

It is a valuable forage crop; while some animals refuse it at first because. of its peculiar taste and odor, they soon learn to like it and thrive on it. In food value it does not differ greatly from alfalfa. For hay it should be cut early and is handled in much the same way as alfalfa. A second cutting can usually be secured 40 to 60 days later, if not pastured. It is also used to some extent as an ensilage crop, put into the silo and fed successfully in this way.

silo and fed successfully in this way. light with a drag such as the branch of a tree or a small bush. If conditions are right, the increased yield of corn, the fall pasturage from the clover, the green manure to be plowed under in the Spring as food for the succeeding crop, will make the planting well worth while. Try it and you will be a sweet clover fan.

Prices, Hulled-1 lb., 20c; 5 lbs., 75c. Scarified-1 lb., 25c; 5 lbs., \$1.00; 10 lbs. $\$ 1.50$, not postpaid. If wanted by parcel post add postage. Please write for general quantity prices or submit list of your requirements for special quotations.

\section{Yellow Blossom Sweet Clover}

Melilotus Officinalis or Yellow Blossom Sweet Clover is similar to the White Blossom, and will grow on almost any kind of soil. It is more spreading in habit and does not grow as tall and large as the White Blossom, and for that reason makes a finer and more tender hay. Cattle prefer it to any other sweet clover. It is ten days earlier than White Blossom and on that account is given preference for planting in high altitudes, and is highly recommended for pastures and used in pasture mixtures. See Morton's Pasture Mixture, page 74. Do not confuse this biennial variety with Annual $25 \mathrm{c} ; 5$ lbs., $\$ 1.00 ; 10$ lbs., $\$ 1.50$, not postpaid. If wanted by parcel post add postage. Please write for general quantity prices or submit list of your requirements for special quotations.

\section{Hubam Sweet Clover}

Hubam Clover is an annual plant with a white blossom and was first discovered in 1916, and has now demonstrated that it will do in one year what other clovers do in two. It is a wonderful fertilizer, adding nitrogen and humus to the soil and making a splendid summer and fall pasture. It is a rich hay crop and a a splendid summer and fall pasture. It is a rich hay crop and a
wonderful honey producing plant. It grows 3 to 7 feet high in 4 to 7 months after planting and seems to thrive well in every state. 7 months after planting and seems to thrive well in every state.
Sow 12 pounds per acre broadcast or 3 pounds in cultivated rows in the Spring. Our seed is Colorado grown. Prices, $1 \mathrm{lb}$., 40c; 5 lbs., $\$ 1.90 ; 10$ lbs., \$3.50, not postpaid.

\section{White Dutch Clover (TRIFOLIUM REPENS)} OR LAWN CLOVER

A small, close growing, useful clover of unusual dwarf habit, used extensively in the making of lawns. In fact, no lawn seems just right unless it has a sprinkling of this little white-blossomed clover mixed through it. It is a rapid grower of spreading habit, and can be cut very close to the ground without injury to the plant, which, after cutting, will start making another growth at once.

When used in a mixture for lawns, use two parts of White Clover to ten parts of Kentucky Blue Grass. For pastures use 10 to 12 pounds of White Clover mixed with 20 to 25 pounds of grass seed to the acre. This will give an excellent stand that will form a heavy sod that is almost impossible to stamp out. Prices, 1 lb., $55 \mathrm{c}$; 5 lbs., $\$ 2.50 ; 10$ lbs. $\$ 5.00$, not postpaid. Please write for general tions.

\section{Medium Red Clover}

Red Clover (Trifolium pratense) can be seeded any time from April to October, at the rate of 15 pounds to the acre, and makes a fine early spring pasture. Red Clover is a legume and is there-

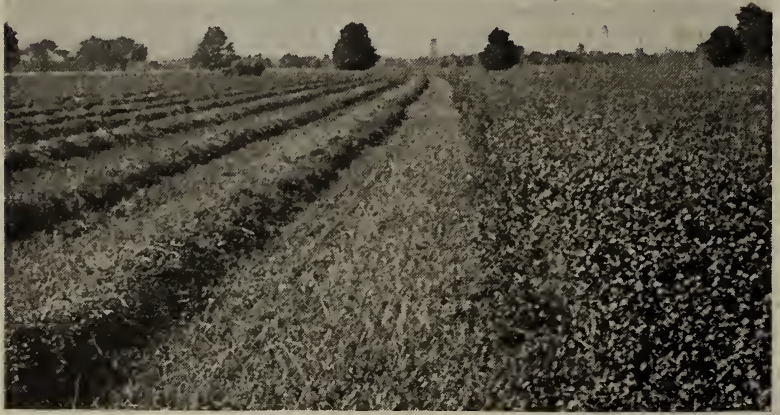

fore a fine soil builder. The hay is fine for all kinds of stock. It can be planted with numerous grasses when hay or pasture is desired, for hay produced from Red Clover is very nutritious and fattening. The seed we are offering is very pure and free from all injurious weed seed. Prices, $1 \mathrm{lb}$., 55c; $10 \mathrm{lbs}$., $\$ 5.00$, not postrequirements for special quotations.

\section{Mammoth Red Clover}

Especially adapted for poor ground and will produce more hay or forage than any clover in the same length of time, but only affords one cutting. It is used mostly for building up run down farms. 8 to 10 pounds of seed to the acre will give you an excellent stand. This is also a pasture clover and is especially valuable on light, sandy soil, supplying excellent grazing, makes good hay if cut when young, but if left too long the stems become thick and woody. Mammoth Red Clover is very valuable for fertilizing purposes, for it restores fertility to depleted soils. The foliage, flower and stem are darker in color than Medium Red Clover. For pasture this clover is hard to beat, being a vigorous grower. Prices, $1 \mathrm{lb}, 55 \mathrm{c} ; 10 \mathrm{lbs}$. 5.00. not postpaid. Please write for general quantity prices or submit list of your requirements for special quotations.

\section{Alsike Clover (TRIFOLIUM HYBRIDUM)}

This is undoubtedly the best high altitude clover for hay and is planted extensively throughout the Rocky Mountain regions where alfalfa often winter-kills. Although not a very heavy yielder, it bears a very thick growth of leaves and blossoms on thin stems, making it a valuable forage crop. When grown alone will make a mair stand the first year, but the second and succeeding years the fair stand the first year, but the second and succeeding years the best results are obtained. Many of our stockmen who raise hay have made it a practice to plant timothy with the alsike and they reap
the finest and most nutritious hay ever fed in the Rockies. The seed we offer is hardy. It was grown in the high altitudes of our mountains where the seasons are short. This makes it pure because the foul seeds that you so often find mixed with the alsike cannot grow in these altitudes. One ton of alsike contains more protein than not postpaid. Please write for general quantity prices or submit list of your requirements for special quotations.

Alfalfa, clovers, soy beans, vetches, peas. beans, cowpeas, peanuts, and other legumes should always be inoculated with Nitragin. The lack of necessary bacteria in the soil is often the cause of a poor legume crop-a weak start-or a total failure. See page 87 .

Under supervision of U. S a total failure. See page 87 . authorized to issue verified-origin seed certificates for alfalfa, clovers, and seed corn, the locality of production of which has been verified by a Federal seed inspector. 


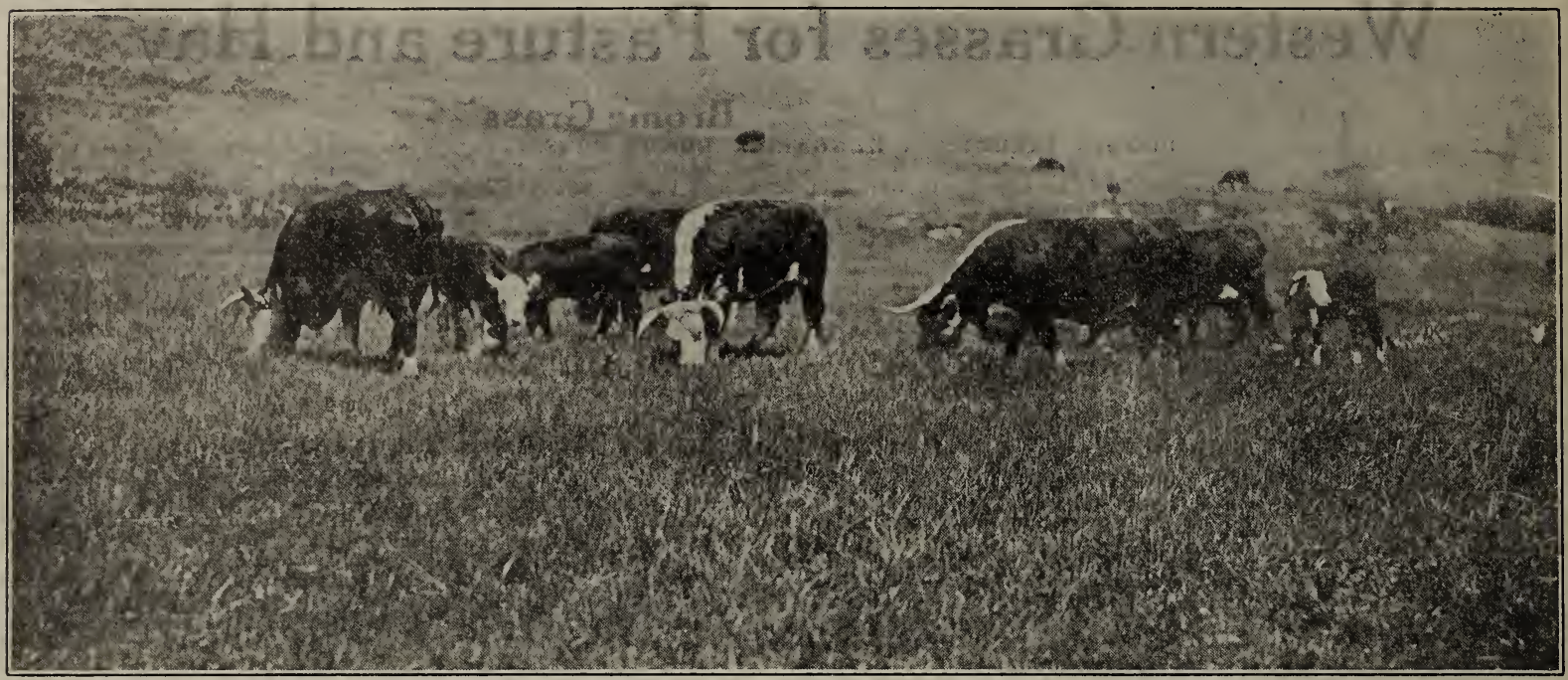

\section{Grasses for Many Purposes}

\section{Alsike and Timothy Mixed}

In cleaning timothy for seed there is always a certain amount of mixed clover and timothy that is taken from the timothy, as it is impossible to separate the two by machinery. So we are offering you a mixed seed, consisting of about 25 per cent of alsike clover and about 75 per cent of fancy timothy seed. To those who are going to plant timothy and clover together, money can be saved by buying this seed, for it is much cheaper already mixed. An excellent stand can be secured by planting 12 to 15 pounds of this mixture. Alsike and timothy hay is much richer in feeding value than timothy alone, for alsike is one of the best clovers for hay, being finer and more leafy than other sorts. Prices, not prepaid: being finer and more leafy than other sorts. Prices, not prepaid: $1 \mathrm{lb} ., 30 \mathrm{c} ; 5$ lbs., $\$ 1.25 ; 10$ lbs., $\$ 2.25 ; 25$ lbs., $\$ 5.00$. Please write
for general quantity prices or submit list of your requirements for for general quantit
special quotations.

\section{Western Wheat Grass}

This is the valuable plant that grows wild over our western country and thrives well in Colorado, Wyoming, New Mexico, and North Dakota. It is the famous bunch grass of the Canadian Northwest. It is one of the best and is the surest hay grass for these sections. It produces large quantities of hay and makes excellent permanent pasture. It, like the wild buffalo grass, is the natural grass of the west and particularly adapted to our prairie soils. It also does well West and particularly adapted to our prairie soils. It also does well on land impregnated with alkali. It withstands drought and the jounds of seed is usually sown to the acre, and if planted with Brome, $71 / 2$ pounds to the acre. The seed being quite heavy, may be sown with any ordinary grain seeder. Plant 1 to 3 inches deep. Prices, not prepaid: $1 \mathrm{lb} ., 20 \mathrm{c} ; 5 \mathrm{lbs}$., 90c; $10 \mathrm{lbs}$., $\$ 1.50$. Please write for general quantity prices or submit list of your requirements for special quotations.

\section{Sheep's Fescue (Festuca ovina)}

is a bunch grass, growing in tufts 3 to 6 inches in diameter, with wirelike leaves 2 to 4 inches long, of bluish gray. When mixed with other grasses it is excellent for fairways on poor sandy soils. Sown alone it is too bunchy. Price, not prepaid: $1 \mathrm{lb}$., 50c; $5 \mathrm{lbs}$. $\$ 2.40 ; 10$ lbs., $\$ 4.50$.

\section{Hard Fescue (Festuca duriuscula)}

A variety of sheep's fescue. Leaves broader, wirelike, not flat. Grows in bunches if sown alone. Will thrive on thin, sandy soil and is used for the "rough." Price, not prepaid: $1 \mathrm{lb}$., 50c; $5 \mathrm{lbs}$., $\$ 2.40 ; 10$ lbs., $\$ 4.50$.

\section{Red Fescue (FESTUCA RUBRA)}

Is also called Creeping Fescue on account of its creeping habit. Well adapted for dry, sandy, inferior soils, on exposed hillsides and in the shade. A very fine grass for putting greens. Prices, not in the shade. A very fine grass for putting $\mathrm{g}$
prepaid: $1 \mathrm{lb}$., $50 \mathrm{c} ; 5 \mathrm{lbs}$., $\$ 2.40 ; 10 \mathrm{lbs}$., $\$ 4.50$.

\section{Chewings Fescue (Festuca Chewings)}

This grass spreads out, forming a plant one foot in diameter, making a solid compact turf of a dark green color. It grows exceedingly well on soils of a sandy nature and is now recognized as one of the leading grasses for putting greens. Prices, not prepaid: one., $1 \mathrm{b0c} ; 5 \mathrm{lbs}$., $\$ 2.90 ; 10 \mathrm{lbs}$., $\$ 5.50$.

\section{Mountain Meadow Mixture}

Will do well in high altitudes, making a heavy, thick sod that withstands the severe colds. Can be sown in the Fall or. Spring, using about 25 pounds to the acre. On account of its rapid growth satisfaction is attained the first year. An excellent sort for mountain meadows and high lands. If allowed to grow, it will produce a fine crop of clean, nutritious, well-proportioned hay, which may be cut and cured for winter use and the field can be pastured without injury to the next year's crop. Prices, not prepaid: 1 lb., 40c; 5 lbs., $\$ 1.75 ; 10$ lbs., $\$ 3.25 ; 25$ lbs., $\$ 7.50$. Please write for general
quantity prices or submit list of your requirements for special quantity p
quotations.

\section{Morton's Pasture Mixture}

The Colorado Agricultural College recommends the following ratio for a well-balanced permanent pasture mixture and gives these quantities as the proper amounts to sow per acre, reseading the clover every two years:

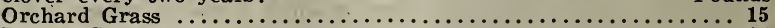

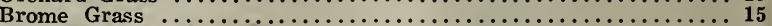

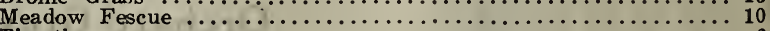

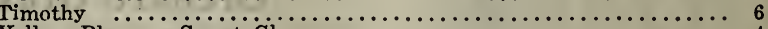

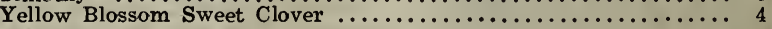

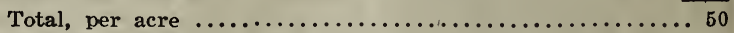
These seeds should not be mixed before sowing. Sow the grass seeds separately from the timothy and clover. The better the quality of the seeds used in the mixture the better the stand obtained.

If cattle are eating quietly instead of hunting for feed, their gain will be quicker with more profit. Good pastures will also turn dairying into a profitable business. Arrange to have better pastures and better stock.

\section{Mixture for Alkaline Lands}

Experiments conducted under supervision of the Department of Botany of the Colorado Agricultural College have shown that the following mixture gives fine results on lands infested with alkali: Yellow Sweet Clover (Melilotus Officinalis) ............... Slender Wheat Grass or Western Wheat Grass (Ägropyrum

Tenerum ) ........................................

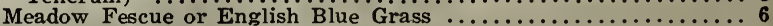

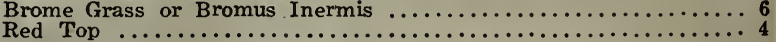

Total Pounds per Acre .30

This mixture has done well under very severe conditions.

\section{Rough Stalked Meadow Grass (POA TRIVIALIS)}

A spreading, thickly matted grass with narrow leaf blades, flat and dark green in color. Forms a fine turf and is suited for moist and shady situations and stiff clay soil. Used for fairways under trees. Price, not prepaid: $1 \mathrm{lb}$., $\$ 1.00 ; 5 \mathrm{lbs} ., \$ 4.85$.

Better Seeds-Better Crops. Better Pastures-Better Stock. 


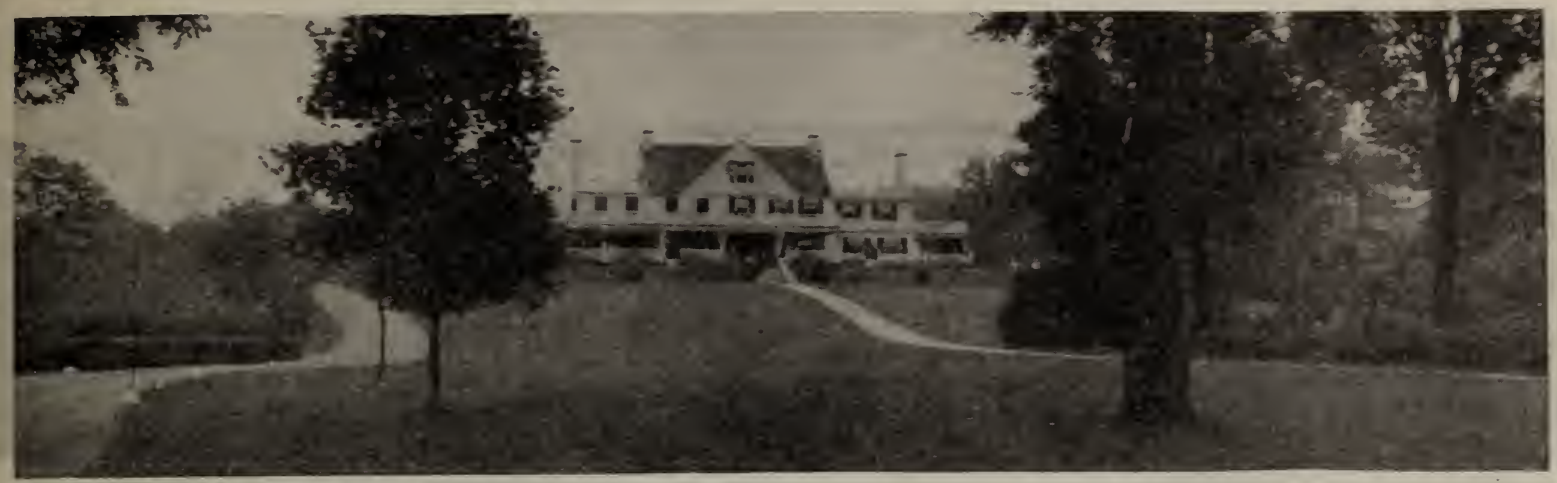

\section{Western Lawn Grass Seed}

HOW TO MAKE A LAWN

If a lawn is to be established about a new dwelling and such land is corered by clay from excavations and by refuse from building is covered by clay from excavations and by portion of this sterile operations, it wil with good, fine, loamy soil to a depth of at least soil and replace it with good, fine, loamy soil to a depth of at least a foot. Work into this soil a liberal quantity of pulverized sheep manure, about 100 pounds to 1,000 square feet. This fertilizer is a quick, sturdy growth of grass. It is better to use pulrerized manure as it can be easily incorporated in the soil, and the plant food it contains is quickly arailable, but there are other fertilizers that may be used.

The seed will germinate quicker if subsurface moisture has been stablished by thoroughly wetting the soil at intervals of a few days before the seeding. After this has been done and the ground leveled off even with the walks, rerake the surface, making it finely pulrerized, then roll or tamp the ground and sow the seed, using one pound to 100 square feet

Select good Kentucky blue grass. It makes a nice, velvety lawn. But some people prefer a sprinkling of white clover. This is a very fine seed and one pound of white clover to four pounds of blue grass is a suitable ratio. In shady places and north exposures, Kentucky blue grass does not do so well and hardier grass may be required.

After spreading the seed as uniformly as possible rake it in lightly, but see that the seeds are all covered. Then firm the soil. This is best accomplished by rolling. If no roller is available, tamp the soil It is now a good idea to spread a mulch of pulverized sheep manore, or other fine manure, over the surface of the newly-made lawn. nure, or other fine manure, over the surface of the newir-made lawn. This helps to retain the moisture and prevents the soil from crust-
ing after irrigation. The young blue grass plant is not strong

\section{Kentucky Blue Grass (POA PRATENSIS)}

Makes by far the most beautiful lawn. It is often planted in conjunction with white clover. If sown by itself for a meadow or pasture, sow about 28 pounds to the acre. When planted for lawn, about 150 pounds to the acre, or one pound to every 100 square feet. This makes the best, sweetest, and most nutritious pasture for all stock. It is the first to start up in the Spring and remains green cold hot sun or tramping of hofs. The roots are so thick and stout that they form a tough sod. It is often sown in a mixture. It will do well on almost any land. Prices on best grade, not prepaid: 1 lb. 40c; 5 lbs., $\$ 1.75$. Please write for general quantity prices or submit list of your requirements for special quotations.

\section{Emerald Lawn Mixture}

Ar unrivaled mixture of the purest and cleanest seed. It contains only the highest grade of grasses suitable for the purpose of making a beautiful, durable, and lasting lawn. Our Emerald lawn grass germinates quickly, roots deeply, withstands the extreme heat of Summer and the severe cold of Winter; makes a beautiful, rich, $10 \mathrm{lbs}, \$ 3.50 ; 25 \mathrm{lbs}$, $\$ 7.50$. Please wite for general quantity prices or submit list of your requirements for special quotations.

\section{English or Perennial Rye Grass (LOLIUM PERENNE)}

Rye grass, like Kentucky blue grass, forms a dense, even sod, and grows so quickly that by its use a fine lawn may be had in six weeks from sowing. It makes a quicker, leafier growth than any other grass, succeeds in the shade as well as in the sun, and may be sown with good results in orchards or woodland pastures. Prices, imported seed not prepaid; 1 lb., 30c; 5 Ibs., \$1.40; 10 lbs, $\$ 2.70$ 25 lbs, \$6.50. Please write for general quantity prices or submit $t$ of your requirements for special quotations.

\section{South German Creeping Bent Grass (AGROSTIS SPECIES)}

As this grass is low growing or creeping in its habits, spreading by means of runners, it tends to form a close, heary, velvety turf that can be cut close without spoiling the appearance of the lawn. These characteristics help it to smother dandelions, weeds, and crab grass and it is being used for that purpose. Prices, not prepaid : 1 lb., $\$ 1.25 ; 5$ lbs., $\$ 5.50$. Please write for general quantity prices or submit list of jour requirements for special quotations.

\section{enough to break a heary}

Commence watering as soon as the seed is sown. It is best to wet the soil thoroughly at intervals of a few days, rather than to sprinkle lightly every day. Watering in the evening after the heat
of the day is past is most efficient. Use a very fine spray. A mist is best, and do not, under any circumstances, use a heary stream, or else the seed will be washed out.

Seeding may be done in the Spring, early enough to permit the plants to establish some root growth before real hot weather commences. Successful planting can be made in August and September. To secure a soft, even, elastic surface, a lawn should be frequently mowed, but it should not be cut very close at first as this will expose the roots to the sun. It is best to cease moving in the Fall
before the winter's cold sets in so that the roots mas be protected before the winter's cold sets in so that the roots may be protected
by a moderate growth of foliage. by a moderate growth of foliage. Spring, rake in some new seed. A thick turf makes a finer looking lawn and it is harder for weed seeds to get a start when there are no open spaces between the tufts of grass. They do not have as good a chance to take root

\section{Fertilizing}

Every lawn needs an annual dressing of fertilizer. Bone meal and pulverized sheep manure are put up in convenient form to handle. They are excellent substitutes for stable manure do not add a crop of weed seeds to the lawn, and are not unsightly and obnoxious. Some kind of plant food should be applied early every season so that the spring snows and spring rains will carry the fertilizing elements down to the grass roots, where they will do the most good.

\section{Canada Blue Grass (POA COMPREsSA)}

Somewhat resembles Kentucky blue grass, but does not grow so tall. It is grown very extensively in Canada and is especially adapted to our western country. It will stand more drought and is more hardy than Kentucky blue grass; thrives on most all kinds of soils. As it is a native Canadian grass, it stands the cold, serere Winter. It makes excellent lawns and pastures, but when planted for pasture $50 \mathrm{c} ; 5$ lbs., $\$ 2.25$.

\section{Bermuda Grass (CrNodor DACTrLON)}

A southern grass with dwarf habits, long creeping stems rooting at the joints that corer the ground with a matting of fine turf.
Not suited for northern latitudes. Price, not prepaid: 1 lb., 50c; 10 lbs., $\$ 4.50$.

\section{White Dutch Clover}

Adds to the appearance of the lawn and is the only clover that should be sown in lawns. For prices and complete description, see page 72 .

\section{Colonial Bent Grass (AGrostis TENUIS)}

This is a rery fine leaved grass that grows quite dense and compact. By some authorities it is considered the best trpe of the bent grasses for lawn making. It is now being used on golf courses and $\$ 1.50 ; 5$ lbs., $\$ 6.25 ; 10 \mathrm{lbs}$., $\$ 11.50$. Please write for general quantity prices or submit list of your requirements for special quotations.

\section{Cocoos Bent Grass (Agrostis Maritima)}

This is also known as Seaside Bent or Oregon Bent. It is a true creeping bent, a native of our western coastal regions and is used on the putting greens of golf courses. It is a rapid grower, heals quickly, and is capable of resisting serere drought, coming quickly to life as soon as moisture is supplied. Prices, not prepaid: $1 \mathrm{lb}$.,
$\$ 1.75 ; 5 \mathrm{lbs}$., $\$ 7.50$. Please submit list of your requirements for special quotations.

\section{Golf-a-Lawn (AGROSTIS SP.)}

An improved, selected strain of Seaside Bent, grown in Oregon, and shipped to us in sealed bags. Prices, not prepaid: $1 \mathrm{lb}$, \$2.25; 5 lbs., $\$ 11.00$. 


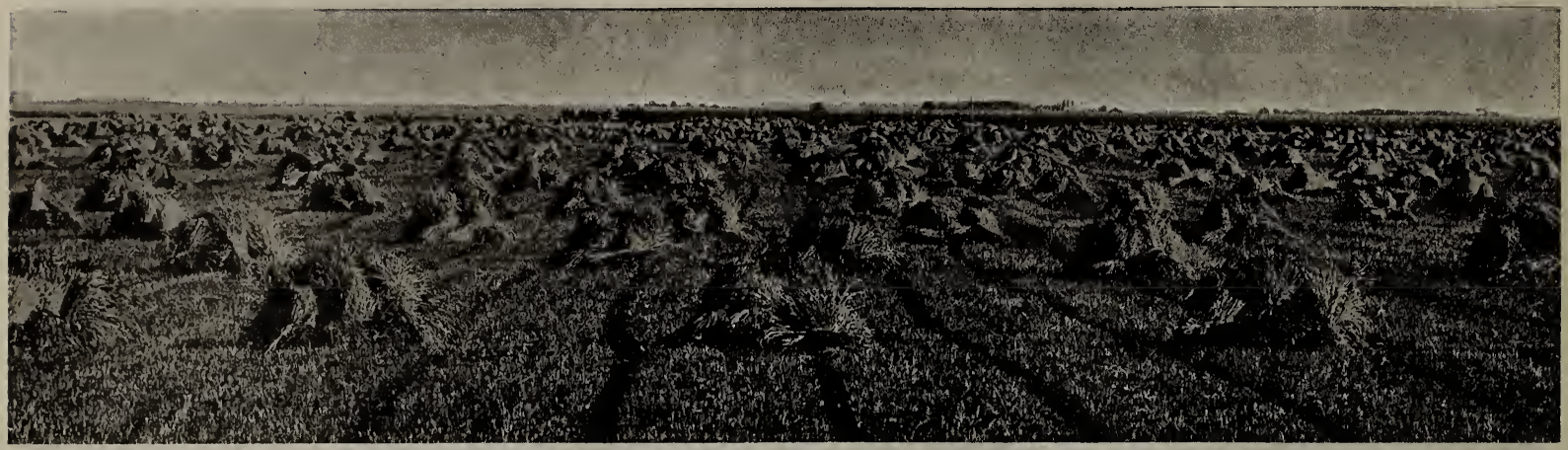

\section{Western Seed Wheat}

\section{Marquis Wheat}

Is a very early, beardless, hard, red, spring wheat, very productive. It has higher milling and baking qualities than most of the varieties of spring wheat known today, and will almost always grade No. 1 . Besides being about 10 days earlier than most spring wheats it generally outyields them and has been known to produce 45 to 60 bushels per acre.

As it is short, stiff strawed, it is not likely to lodge and stands up well under irrigated conditions in Colorado. The grain is plump and of a dark red appearance. Prices, not prepaid: 1 lb., 15c; 5 lbs., 50c; 10 lbs., 80c; 25 lbs., \$1.50. Please write for general quantity prices or submit list of your requirements for special quotations.

\section{Kitchener Wheat}

Kitchener wheat is a new type of spring wheat that originated in 1911 in Saskatchewan, Canada, from a single plant selection from Marquis. It is an absolutely new and distinct variety. Large, plump berries are carried on multitudes of uniform stems of exceptional length and strength. This carries the head and straw very erect and prevents the wheat from leaning over. The wheat is very vigorous and ripens about the same time as Marquis, but the grains are larger, fuller, and plumper. It is easy to thresh. It has given good results in districts of light rainfall and has suffered less damage from hail than other varieties. In Saskatchewan yields of 63 and 80 bushels per acre have been recorded.

80 bushels per acre have been recorded. In normal seasons it is a sure indication that the crop is ready
to be cut when it shows a purple band of color below the head and another near the ground, although the head and the rest of the straw show some green.

Sow 20 to 30 pounds on dry land and 70 to 75 pounds on irrigated land. Prices, not prepaid: 1 lb., 15c; 5 lbs., 50c; 10 lbs., 80c. Please write for general quantity prices or submit list of your requirements for special quotations.

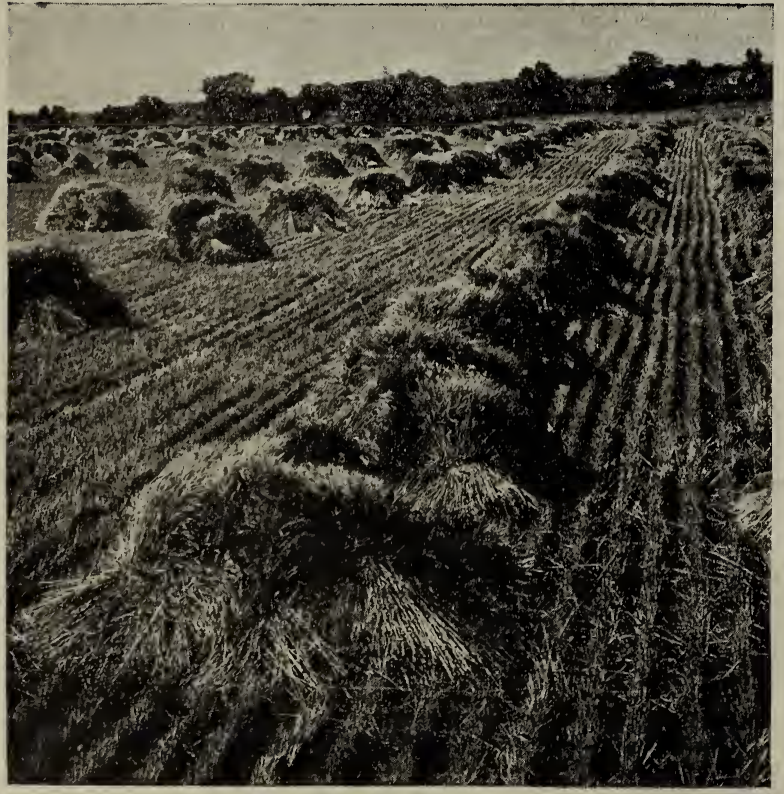

[76]

\section{Defiance Wheat}

The old standard variety of spring wheat planted extensively in the Middle West as the main crop wheat. The Defiance is a perfect wheat with extraordinarily heavy yielding qualities. The kernel is plump, and if harvested before being allowed to over-ripen, it never shells out of the hull. The stalk is medium in height and makes excellent straw. It is not termed a dry land wheat, but oftentimes good yields are reported from dry lands. Defiance is considered one of the best milling varieties grown. It is beardless. Prices, not write for general quantity prices or submit list of your requirements for special quotations.

\section{Macaroni or Durum Wheat}

This wheat grows very strong and with surprising rapidity, so rapidly as to get ahead of the weeds, and not only are the growing qualities in its favor but it is also a heavy yielder. Macaroni wheat produces as good a yield of grain to the acre as most any other variety. It does not shell or bleach and is hail proor to a certain extent, owing to the tightness of the hull. It is not a milling wheat, but is grown only where other varieties do not mature or thrive, wheat very seldom fails to produce grain even on our dry lands where it has won the favor of the dry farmers as a sure wheat crop. It has a very hard kernel and is known as a glue wheat, and is bearded. Prices, not prepaid: 1 lb., 15c; 5 lbs., 50c; 10 lbs., 80c; 25 lbs., $\$ 1.50$. Please write for general quantity prices or submit list of your requirements for special conditions.

\section{Turkey Red Winter Wheat}

A standard red bearded wheat with very strong straw. It is early, ripening before rust and insects appear. Average yield is 30 to 40 bushels to the acre. The kernels are large, red, and hard, and it is in good demand by millers and most always grades No. 1 . Prices will be supplied upon request throughout the Summer. Prices, not prepaid: 1 lb., 15c; 5 lbs., 50c; 10 lbs., 80c; 25 lbs., $\$ 1.50$. Please write for general quantity prices or submit list of your requirements for special quotations.

\section{Kanred Winter Wheat}

Kanred wheat is the product of a single head of wheat selected in 1906 from a hard winter variety that had been introduced from Russia by the United States Department of Agriculture.

An early maturing wheat generally makes a bigger yield, as it escapes the hot winds and drouth, occasional rust, and is generally harvested before the season for hail. On the whole, it can be said that as far as known, Kanred always ripens earlier than Turkey red. Careful experiments by agricultural experiment stations show that Kanred is markedly resistant to rust, that it is immune to certain kanred is markedly resistant to rust, that it is immune to certain kinds of black stem rust and has been injured much less than other varieties when orange leaf rust was prevalent. Other experiments bushels per acre more than Turkey red. It is bearded. Prices, not prepaid: $1 \mathrm{lb}$., 15c; 5 lbs., 50c; 10 lbs., 80c; 25 lbs., \$1.50. Please write for general quantity prices or submit list of your requirements for special quotations.

TREATMENT FOR BUNT OR STINKING SMUT IN WHEAT

Dust seed grain with copper carbonate two to four ounces to the bushel. Mix in a barrel mixer so that all grains are covered with the dust. Treatment can be made at any time and grain can be stored without injury. 


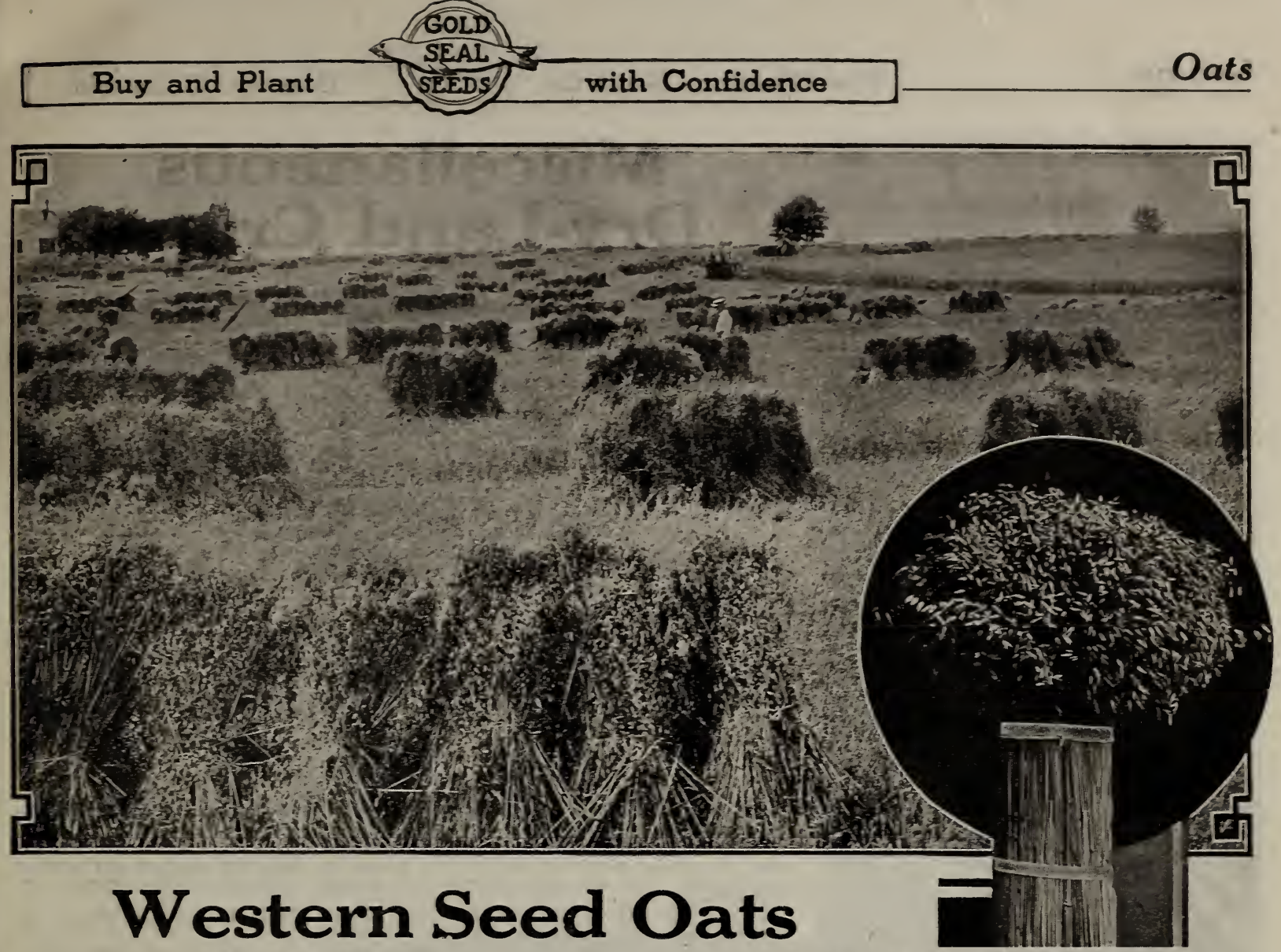

Bliss Side Oats

A selection from the white Russian side oats which has been and still is in some sections a favorite with many. Mr. E. R. Bliss, of Weld County, striving to get oats that were pure, made the field selection from heads showing desirable characteristics and has care fully developed from this.

This oat is registered under the rules of the Colorado Seed Growers Association and tested by the Colorado Seed laboratory.

Experience shows that the type of head which this oat has with the grain all drooping from one side of the stem, is not damaged so badly by grasshoppers and light hail as the branched tspe of head. feeding is desired, this is one of the best that ean be planted for that purpose. The Bliss side oats ripen uniformly, the fields present a very attractive appearance, and the vield of grain is usually very satisfactory. Owing to the small size of the grain, many are led to believe it has not the feed value of larger oats, but it is true that the percentage of meat to the hull is about the same as in the larger types and the thin hull permits it to be more easily digested.

The side oat has proven to be a very satisfactory cat for mountain districts.

Our first offering will be registered stock grown by Bliss.

Prices, not prepaid: 1 lb., 15e; 5 lbs., 50c; 10 lbs., 80c; 25 lbs., \$1.50. Please write for general quantity prices or submit list of your requirements for special quotations.

\section{Silver Mine Oats}

This oat has the reputation of being an exceedingly herry and reliable vielder. The heads are very large in proportion to the stiff, bright, clean straw. The sprangle top heads, although long, are borne low down on the stalk, which seems to prevent lodging. The demand for this variety last season exhausted our supply and we suggest early orders to avoid disappointment. Prices, not prepaid: $1 \mathrm{lb} ., 15 \mathrm{c} ; 5 \mathrm{lbs} ., 50 \mathrm{c} ; 10 \mathrm{lbs}$., $80 \mathrm{c} ; 25 \mathrm{lbs}, \$ 1.50$. Please write for
general euantity prices or submit list of your requirements for special general gua
quotations.

\section{Abundance Oats}

Originated in Canada, are of the Swedish select type and are known by a great many other names in different parts of the country. Grain is plumper than Victory and not so long. They have won Sweepstakes several times at the International grain and hay shows and at the Colorado State seed show. Prices, not prepaid: 1 lb., 15c; 5 Jbs., 50c; 10 lbs., 80e; 25 lbs., $\$ 1.50$. Please write for general quantity prices or submit list of your requirements for special quotations.

TREATMENT FOR LOOSE SMUT AND COVERED SMUT

Add one pint formaldehyde to forty gallons of water and sprinkle on forty bushels of grain. Cover with sacks or canvas for two to four hours.

\section{Colorado No. 37 Oats}

This variety was produced by selection. The original mother plant was selected from a field of oats in the San Luis Valley, but further purification and selection has been made by the agronomy department at the a r panicled white oat ment at the but the straw is stiff and it is well adapted for irrigated conditions and cocler dry land conditions. It yields well and has led other varieties over a period of years. Prices, not prepaid: $1 \mathrm{lb}$., $15 \mathrm{c}$; $5 \mathrm{lbs}$, $50 \mathrm{c} ; 10$ lbs., 80c; 25 lbs., $\$ 1.50$. Plcase write for general quantity prices or submit list of your requirements for special quotations.

\section{Victory Oats}

Ever since the war many different oats have been sold under the name of Victory. Some of these were good and some not so good but it was apparent that no one knew which was the true Victory as introduced into Canada from Sweden. The oats now registered under the name Victory in Weld County are all from the same imprese secured as second generation seed from the Canadian government breeding plots in Edmonton, Alberta, Canada, in 1924

This Victory is a Swedish type oats with large-sized plump grain and thin hull. The plants are hardy and yield well under irrigation. Genuine Victory oats are good size, plump, solid grain and are especially desirable because of the thin hull and plump kernel; orer 90 per cent of the grain is meat. This is very essential to good oats. More grains set on the head than varieties that have a big, thick hull. Victory oats are the hardiest oats grown; they are early and make

One field of registered oats in Weld County yielded 102 bushels per acre and the average of four growers was 88 bushels. Prices, not prepaid: $1 \mathrm{lb}, 15 \mathrm{c} ; 5 \mathrm{lbs} ., 50 \mathrm{c} ; 10 \mathrm{lbs}$, $\$ 1.50$. Please write for general quantity prices or submit list of your requirements for special quotations.

\section{Swedish Select Oats}

It is an abundant yielder of heavy fine grains. It is rigorous and produces fine straw of excellent quality. The seed we offer is especially adapted to our western country, being earlier and more drought resistant than the oats offered from other sections. As it produces excellent straw it is grown extensively in our mountains and cut just before the grain ripens and used for hay. Prices, not prepaid: $1 \mathrm{lb}$., $15 \mathrm{c}$; 5 lbs., 50c; $10 \mathrm{lbs} ., 80 \mathrm{c} ; 25 \mathrm{lbs}$., $\$ 1.50$.

\section{Kherson or Mountain Oats}

This is the earliest oat known. It is also adapted to dry land Although it does not grow as long as most other varieties yet it is a heary vielder. The grains are rather slender but the kernel is quite plump. This year we will be able to supply Registered Kherson $10 \mathrm{lbs}, 80 \mathrm{c}: 25 \mathrm{lbs}$. $\$ 1.50$. Please write for general quantity prices or submit list of your requirements for special quotations. 


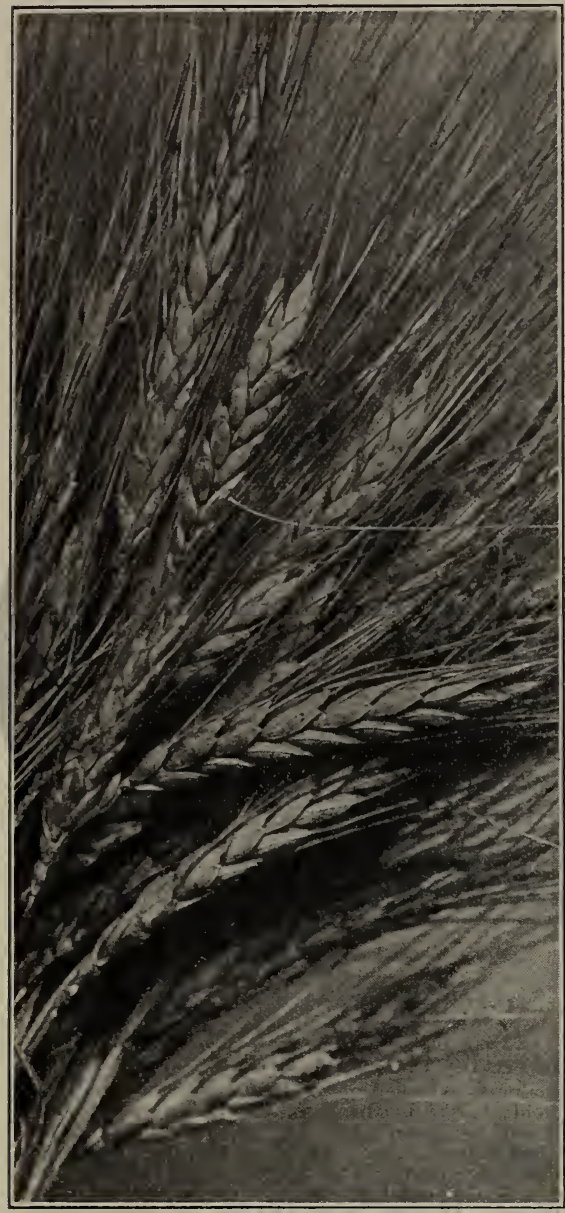

Speltz.

\section{Miscellaneous Dry-Land Crops}

\section{Speltz or Spring Emmer}

The wonderful merits of this grain have placed it at the top of the list, especially among the dry-land farmers.

As seen in the picture, it resembles barley and wheat, and is classed with them. It will make a crop under the most unfavorable soil and weather conditions, and is one of the first spring grains to ripen, being of very rapid growth. If it is feed that you desire, don't overlook speltz, for all kinds of stock do well on it and you can harvest more speltz from an acre than either oats, wheat or barley.

Each year we are having more calls for speltz, and in almost every case where small quantities were sold for trial purposes, the growers are now planting on a large scale. If you have never tried this grain, we urge that you give it a trial, and make it a good one, for it is a certain pleaser. In planting speltz you sow from 50 to 75 pounds to the acre but on dry land 40 to 50 pounds are sufficient. When ready to buy
for special price; state the quantity wanted and we will gladly submit samples.

Prices, lb., 15c; 5 lbs., 50c; 10 lbs., $80 \mathrm{c} ; 25 \mathrm{lbs}$., $\$ 1.50$. Please write for general quantity prices or submit list of your requirements for special quotations.

\section{Western Flax Seed}

Flax is one of the most dependable and profitable crops grown in the West. Because of its short growing season and quick maturing qualities it may be planted as late as the middle of June and make a matured crop almost anywhere in the United States, and is one of the most desirable late crops to grow on fields where clover pasture or meadows have winter-killed or have been destroyed by the effects of water and ice. Flax takes less fertility and moisture from the soil than the grains, clovers or grasses during its growing season. This has been proven by careful soil tests.

Flax will vield 10 to 20 bushels per acre under favorable soil and weather conditions and is usually much more profitable than any of the grains: Flax straw is saleable and is now used in large quantities by manufacturers of upholstered furniture and insulation for building purposes.

It may be used with success as a nurse crop for the clovers and grasses as it does not shade the seedling plants as much as the grains and takes less moisture and fertility from the soil. Flax is a most desirable crop to grow on native sod the season it has been plowed.

Treating flax seed with formaldehyde will destroy wilt germs and thus prevent infecting the soil. Sow more flax this year and every year.

Prices, $1 \mathrm{lb} ., 20 \mathrm{c} ; 5 \mathrm{lbs}, 90 \mathrm{c} ; 10 \mathrm{lbs} ., \$ 1.75$. Please write for general quantity prices or submit list of your requirements for special quotations.

\section{Dwarf Essex Rape}

A forage plant of highest value. It can be sown in April for an early crop, and for Fall crop in July, August, and September, and still later further South. In a few weeks from the time of sowing hogs and cattle can be turned on it. Under favorable conditions rape is ready for pasturing sheep or cattle within six weeks from time of sowing, and on an average one acre will carry 12 to 15 sheep six weeks to two months. When on the rape they should at all times have access to salt. Pigs and cattle are also very fond of it. The plant is a rank grower and should have heavy manuring as well as high cultivation. Any corn soil will grow rape. Sow the seed by the end of June and the crop can be ready to feed at a season when it is most now the seed by the end of June and the crop can be ready to feed at a season when it is most and clean, sow broadcast; if not so clean, sow in drills and cultivate as for corn. When sown broadcast, use 5 to 6 pounds, and if in drills, 2 to 3 pounds to the acre.

Prices, purchaser paying express or freight charges: $1 \mathrm{lb}$, 25c; 5 lbs., $\$ 1.00 ; 10 \mathrm{lbs}$., $\$ 1.75 ; 25 \mathrm{lbs}$. $\$ 3.75$. Please write for general quantity prices or submit list of your requirements for special quotations.

\section{Buckwheat}

Buckwheat does best where the climate is moist and cool, but it is sensitive to cold. It is a short season crop, maturing in 10 to 12 weeks and can be sown later than any other grain crop. It is a
good crop for poor, thin land, does well on acid soils and serves to make hard land mellow and friable and is a good crop to use in preparation for such a crop as potatoes. Sow 1 to $1 \frac{1}{2}$ bushels per acre. Light, well-drained soils are best for this crop.

JAPANESE BUCKWHEAT. Entirely distinct from all other varieties. It has the advantage of remaining for some time in bloom and produces seed earlier. On this account it can be grown farther North. It resists drought and blight very well. As much as 40 bushels to the acre have been harvested of this variety, making it very profitable to raise.

SILVER HULL BUCKWHEAT. This valuable variety originated abroad. It is early; remains longer in bloom than other sorts. A fine variety for honey bees. The grain is of beautiful light gray color and has a thin husk.

Prices, $1 \mathrm{lb}$., $15 \mathrm{c} ; 5 \mathrm{lbs} ., 60 \mathrm{c} ; 10 \mathrm{lbs} ., \$ 1.00$. Please write for general quantity prices or submit list of your requirements for special quotations.

\section{Peanuts}

Can be successfully grown in almost any place where corn succeeds, but thrive best on light sandy soil. The vines are valuable feed for horses, cattle, and sheep. One acre will produce from one to two tons of vines. The nuts are relished by nearly everyone and contain a large percentage of nutriment.

IMPROVED LARGE VIRGINIA PEANUTS. A very profitable variety to grow. The vines make valuable forage for stock. By mail, postpaid, large pkg., 10c; 1 lb., 30c. Not postpaid, 5 lbs., $\$ 1.00$; 10 lbs., $\$ 1.75$.

SPANISH PEANUTS. Pods are small, remarkably solid, well filled, and of an extra fine quality. Yield per acre very large, Large pkt., $10 \mathrm{c} ; 1 \mathrm{lb}$., 30c, postpaid. Not postpaid, 5 lbs., $\$ 1.00 ; 10$ lbs., \$1.75.

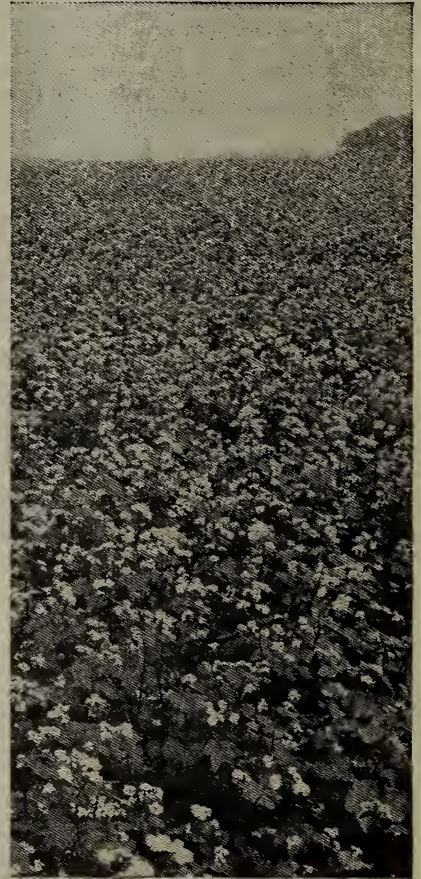

Buckwheat, 


\section{Western Seed Grains}

\section{Trebi Barley}

Imported by the U. S. Department of Agriculture in 1905 from Asiatic Turkey where it had been under irrigation for many years. Trebi is a six-rowed, pure line variety with heads similar to those of Coast barley. Under government tests in California and Minnesota it did not show up well, but when taken to experiment station made pure line selection that greatly improved its yield and quality and distributed it to our western farmers.

It was introduced into northeast Colorado from Idaho about 1920 , and has led other varieties in both yield and quality of grain. It has been in Weld County only three years and is replacing all other varieties by leaps and bounds. Eight growers who had registered fields in 1926 averaged 76 bushels on 115 acres.

The kernels are large and bluish in color and the awns, while long, break off more easily than those of the Coast variety and cause it to thresh out much cleaner. Lamb and cattle feeders in Weld County much the Coast variety and cause it to thresh out much cleaner. Lamb and cattle feeders in Weld County

prefer it to other varieties for feeding. We unhesitatingly recommend this barley for irrigated farms. of years at several dry land experiment stations, and in years with a fair amount of rainfall it has proven to be one of the best. However, under actual dry farming conditions in Logan County, it is gaining popularity rapidly.

Prices, $1 \mathrm{lb} ., 15 \mathrm{c}$; 5 lbs., 50c; $10 \mathrm{lbs}$, , 80c. Please write for general quantity prices or submit list of your requirements for special quotations.

\section{Bald or Hulless Barley}

This is one of the many forage plants that have met with success in our western country and is one of the best crops for green feed. It is very early and grows rapidly, which makes it a favorite where green feed is wanted. It can be used as cured hay, but should be cut or harvested when it is in the milk stage. If allowed to mature will make an excellent grain, which resembles wheat. It is not a milling variety, but when ground is an excellent feed for stock, which do well on it. It resists drought remarkably well. It will make a large crop of grain in dry seasons, even when wheat will fail. Yields well on poor lands and better on good land. It has no beard and shells off its hulls the same as wheat.

Prices, $1 \mathrm{lb}$, $15 \mathrm{c} ; 5 \mathrm{lbs} ., 50 \mathrm{c} ; 10 \mathrm{lbs} ., 80 \mathrm{c} ; 25 \mathrm{lbs} ., \$ 1.50$. Please write for general quantity prices or submit list of your requirements for special quotations.

\section{Colsess Barley}

Colsess barley is a six-rowed hooded variety of hybrid origin, produced and developed by the Agronomy Department of the Colorado Agricultural College. It is the result of a cross between Coast and Success. Heads are more compact and darker than Success but resembling Coast in color. It has been developed to supply a demand for a high yielding barley that is free from beards that many stock feeders object to because of trouble caused by the stiff awns in the threshed rrain snd stran.

From the tests conducted by the Colorado Experiment Station it has outyielded all other hooded varieties and compares
very farorably with the highest yielding bearded varieties. It has proven itself to be especially well adapted to mountain regions and high altitudes, as it is one of the earliest high-yielding varieties.

The straw is stiff, causing it to stand up well under irrigation and it shatters less than Coast or Success. As a beardless variety, under irrigated conditions, it can be depended upon to give greater yields than any other beardless variety yet tried.

Prices, 1 lb., $15 \mathrm{c}$; 5 lbs., 50c; 10 lbs., 80c. Please write for general quantity prices or submit list of your requirements for special quotations.

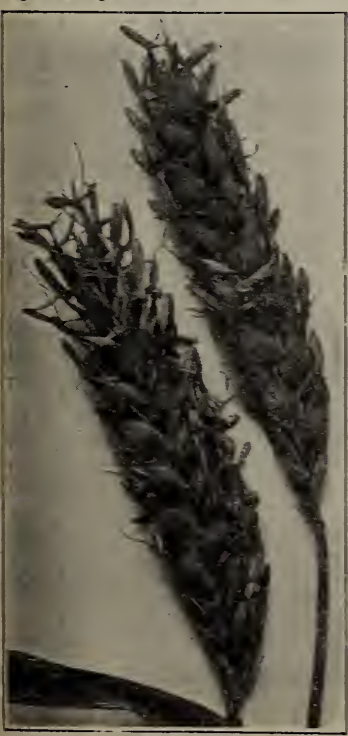

Colsess Barley.

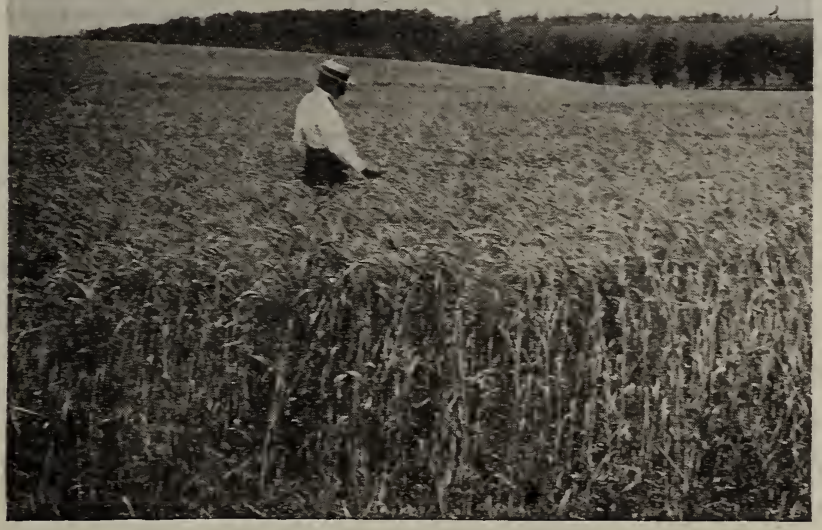

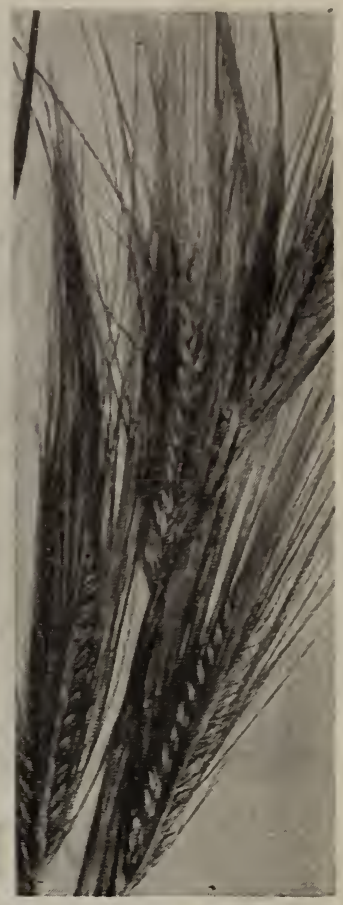

Trebi Barley.

\section{Hulless Blue}

\section{Barley}

While Blue Barley has suffcient hall to hold it in the heads these hulls are easily separated in threshing and the grain shells out like wheat. It is very early, matures in 60 to 90 dass, according to soil and locality. The grain is blue, resembling wheat in shape and exceedingly heary, weighing 60 pounds to the bushel. ing very early and providing rich feed. It should be cut just before it becomes ripe and while the straw is green. In this condition it is relished by all kinds of stock. The straw is stiff and straight, and seldom if ever does it lodge. Blue Barles is bearded. 10 lbs., $80 \mathrm{c} ; 25 \mathrm{lbs}$., $\$ 1.50$. Please write for general quantity prices or submit list of your requirements for special quotations.

\section{Oderbrucker Barley (Six Row)}

Oderbrucker is a tall, heary-strawed barley that stands up well and gracefully. The heads are usually large and long and are completely filled out with very plump grains that are brighter and whiter than any other barley. Our seed of Oderbrucker barley was grown from seed furnished by a careful and successful grower, who took great pains to keep the field clean and free from other grains and our large cleaning machines have graded it so that it is the best grade of barley ever offered by us

Prices, $1 \mathrm{lb}$., $15 \mathrm{c} ; 5 \mathrm{lbs}, 50 \mathrm{c} ; 10 \mathrm{lbs}$., S0c; $25 \mathrm{lbs}, \$ 1.50$. Please write for general quantity prices or submit list of your requirements for special quotations.

\section{Spring Rye}

As a cleaning crop for the purpose of eradicating wild oats and other foul seeds, Spring rye can not be Aeaten It is an excellent soiler and can be produg on wheat would be a comparative failure. Sow Spring rye on ground where winter grain has been killed or blown out or where a fall crop has not been planted. It makes excellent early pasture or may be cut and cured for hay. When sown with vetch its value for pasture and hay is greatly enhanced. It does not grow as tall as Winter rye and the straw is finer but it usually yields well and there is generally a good market
for the grain. Prices, $1 \mathrm{lb}, 15 \mathrm{c}$; $5 \mathrm{lbs}$., $50 \mathrm{c} ; 10 \mathrm{lbs}, \mathrm{s0c} ; 25 \mathrm{lbs}$, $\$ 1.50$. Please w rite for general quantity prices or submit list of your requirements for special quotations.

\section{Rosen Winter Rye}

Selected in 1909 at Michizan Agricultural College from Russian and has made good here, increasing the rje yields to a remarkable degree, even to the extent of excluding the common variety of fall rye. Rosen rye stools well and for this reason is recommended by the Agronoms Department of the Colorado Agricultural College for sowing in the Spring for use as a temporary pasture. Its superiority is shown on dry land as well as irrigated. Since rye is a cross fertilized plant, it becomes it a biennial and it is highly important to get pure seed. Spring and sumer general quantity prices or submit list of your requirements for special quotations. 


\section{Field Corn}

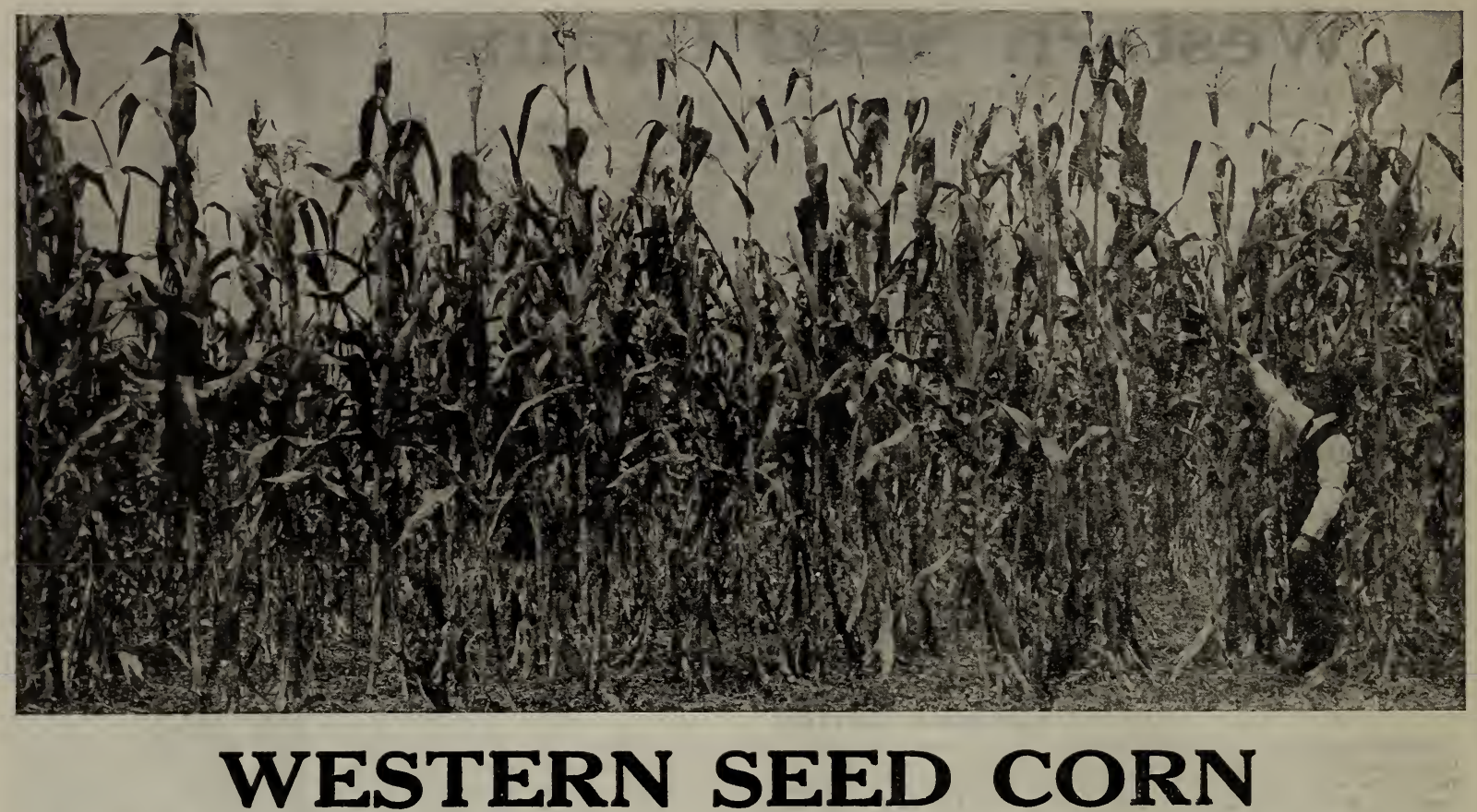

The following tabulation gives average descriptions of the different varieties of field corn named. Of course there will be a variance as to time of maturity, height of stalks, size of ears and yields; dependent on when and where the crops are planted, the kind and fertility of the soil and climatic conditions.

\begin{tabular}{|c|c|c|c|c|c|c|c|}
\hline $\begin{array}{l}\text { Av. No. Days } \\
\text { Planting to } \\
\text { Maturity }\end{array}$ & $\begin{array}{c}\text { Average } \\
\text { Height } \\
\text { of Stalk } \\
\text { Feet }\end{array}$ & $\begin{array}{l}\text { No. of } \\
\text { Rows of } \\
\text { Grain } \\
\text { on Cob }\end{array}$ & $\begin{array}{l}\text { Average } \\
\text { Ear } \\
\text { Length } \\
\text { Inches }\end{array}$ & $\underset{\text { Characteristics }}{\text { Ear }}$ & $\begin{array}{c}\text { Color } \\
\text { Grain }\end{array}$ & Cob & $\begin{array}{l}\text { Distance } \\
\text { of Ears } \\
\text { Above } \\
\text { Ground }\end{array}$ \\
\hline Minnesota No. 13 & 6 to 8 & 12 to 16 & 7 to 10 & Smooth Cylindrical & Yellow & Red & 4 feet \\
\hline Colorado Yel. Dent 90 & 6 to 8 & 12 to 18 & 8 to 12 & Smooth Cylindrical & Yellow & Reddish & 3 to $4 \mathrm{ft}$. \\
\hline Swadley & 5 to 7 & 12 to 16 & 7 to 9 & Cylindrical & Light Yellow & White & 3 feet \\
\hline Golden King & 6 to 8 & 12 to 16 & 8 to 10 & Cylindrical & Light Yellow & White & 3 feet \\
\hline Reid's Yel. Dent & 7 to 10 & 18 to 24 & 10 to 11 & Somewhat Smooth & Deep Yellow & Red & 4 to $5 \mathrm{ft}$. \\
\hline Pride of the North 80 to 90 & 6 to 8 & 12 to 16 & 8 to 10 & Snooth Cylindrical & Yellow & Bright Red & 3 feet \\
\hline King of the Earliest 90 to 100 & 6 to 9 & 18 to 24 & 9 to 10 & Somewhat Rough & Deep Yellow & Red & 4 feet \\
\hline Northwestern Dent Under 90 & 5 to 7 & 12 to 14 & 7 to $91 / 2$ & Smooth Tapering & Red & White & 3 to $4 \mathrm{ft}$. \\
\hline White Australian 85 to 90 & 5 to 8 & 12 to $16^{5}$ & 12 & Smooth Cylindrical & White & White & $3 \mathrm{feet}$ \\
\hline Western White Dent 90 to 100 & 6 to 8 & 16 to 20 & 10 to 14 & Slightly Rough & White & White & 4 feet \\
\hline $\begin{array}{ll}\text { Gehu } & 80 \text { to } 90 \\
\end{array}$ & 4 to 6 & 12 to 14 & 5 to 7 & Smooth Tapering & Yellow & White & 2 feet \\
\hline Hickory King & 10 to 12 & 16 to 18 & 10 to 12 & Large & White & White & 6 feet \\
\hline $\begin{array}{l}\text { Squaw, Blue and } \\
\text { White Flint } \\
\end{array}$ & 4 to 5 & 8 & 8 to 10 & $\begin{array}{l}\text { Smooth } \\
\text { Tapering }\end{array}$ & $\begin{array}{r}\text { Red, Blue } \\
\text { and White } \\
\end{array}$ & White & 2 feet \\
\hline Calico & 6 to 8 & 20 to 24 & 9 to 12 & Large $\quad$ Mottled $\mathrm{R}$ & ed, White, Yel. & White & 4 feet \\
\hline Iowa Silver Mine & 7 to 9 & 16 to 20 & 9 to 12 & Slightly Rough Cyli & ndrical White & Small White & 4 feet \\
\hline Colorado Giant Fodder 110 & 10 to 12 & 20 to 24 & 10 to 12 & Rough Cylindrical & White & Small White & te 4 to $5 \mathrm{ft}$. \\
\hline Red Cob Ensilage 110 & 10 to 14 & 20 to 24 & 9 to 12 & Smooth Cylindrical & White & Red & 5 feet \\
\hline Eureka & 12 tor 15 & 18 to 24 & 12 & Large & White & White & 6 to $7 \mathrm{ft}$. \\
\hline Improved Leaming & 10 to 12 & 20 to 24 & 10 to 12 & Rough & th Reddish Cast & Small White & te 4 feet \\
\hline Iowa Gold Mine & 10 to 12 & 20 to 24 & 10 to 12 & Rough & Golden Yellow & Small White & 4 feet \\
\hline
\end{tabular}

Under supervision of the U.S. Department of Agriculture, we are authorized to issue verified-origin seed certificates for alfalfa, clovers, and seed corn, the locality of production of which has been verified by a Federal seed inspector. 


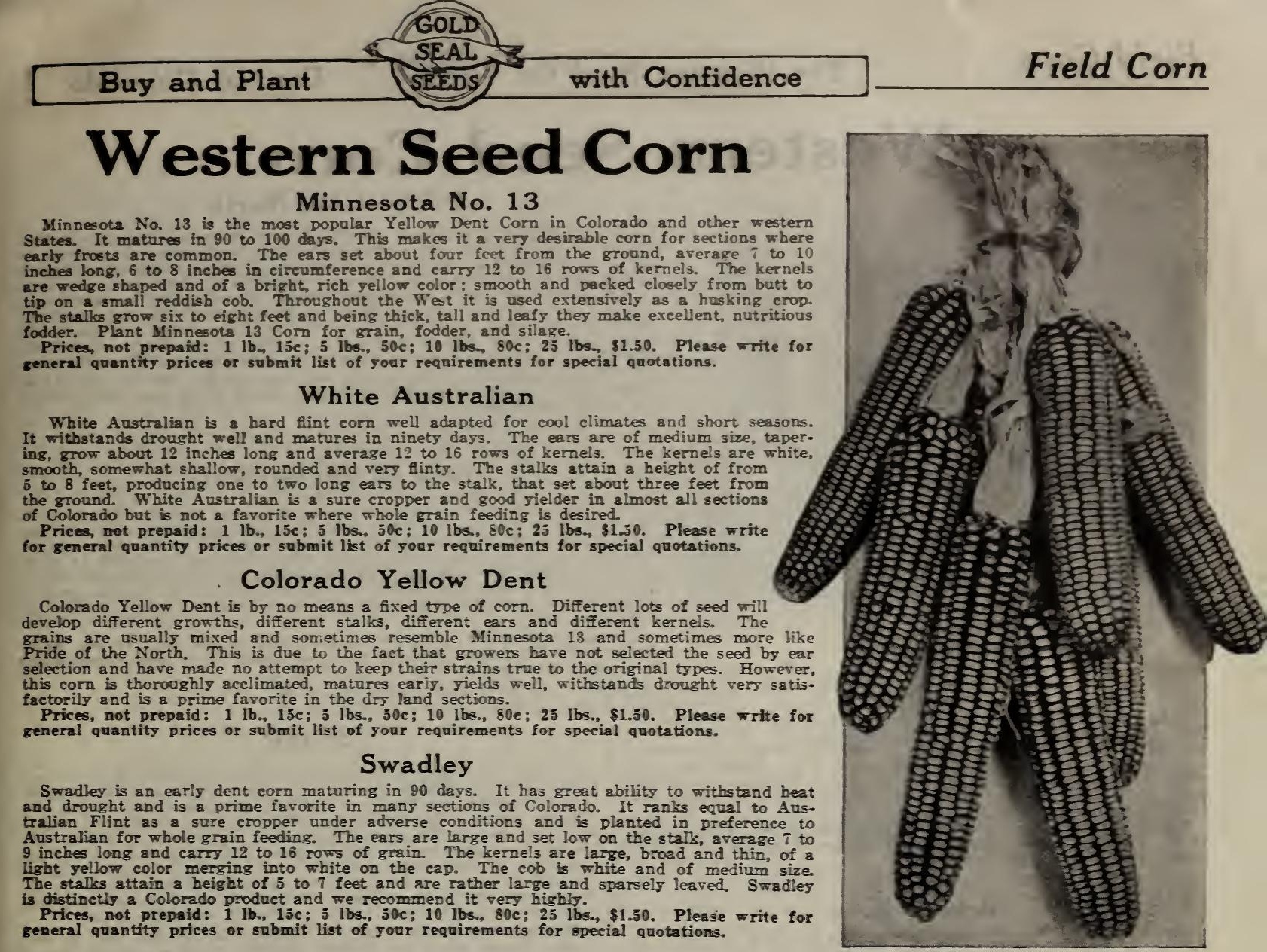

Vinder supervision of the U.S. Department of Agriculture, we are anthorized to issue verified-origin seed certificates for Te are anthorized to issue rerified-origin seed certificates for
alfalfa, clovers, and seed corm, the locality of production of alfalfa, clovers, and seed corn, the locality of productich
which has been verified by a Federal seed inspector.

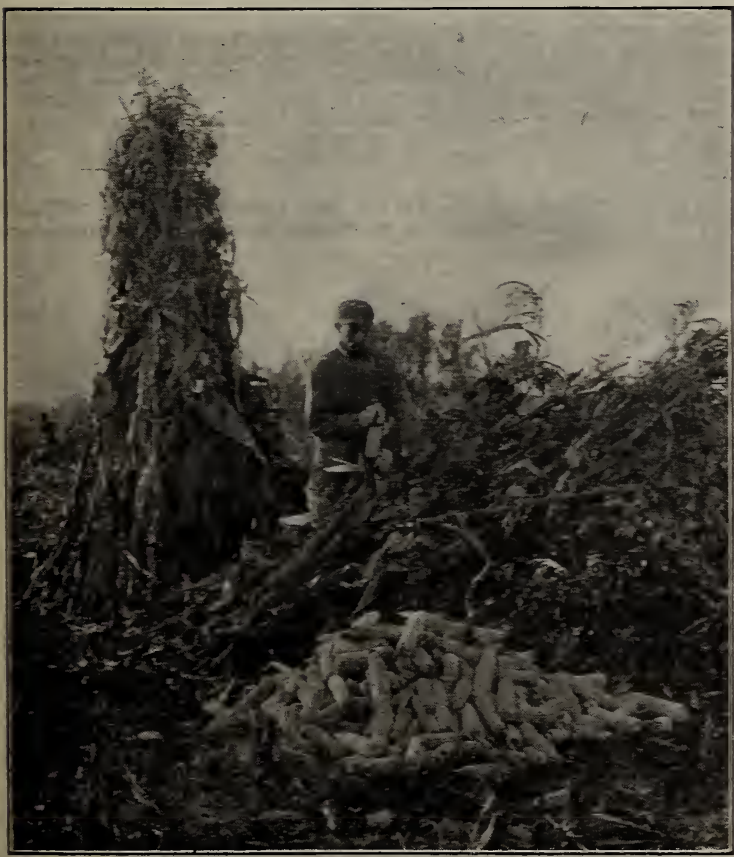

Minnesots No. 13.

\section{Western White Dent}

Western White Dent is a sbort season corn requiring about 90 days to mature. This makes it very desirable where a soft white corn is sought. The stalks average six to eight feet tall with ears 10 to 14 inches long and with 16 to 20 rows of nice, white kernels. The ears are large and the cob small and white. Thes set high making this rariety suitable for husking. It is also a very efficient corn for silage and fodder.

Prices, not prepaid: $11 \mathrm{~b}, 15 \mathrm{c} ; 5 \mathrm{lbs}, 50 \mathrm{c} ; 10 \mathrm{lbs} 80 \mathrm{c} ; 25 \mathrm{lbs}$; 1.50 . Please write for general quantity prices or submit list of your require ments for special quotations.

\section{Northwestern Dent}

Northwestern Dent is a short season corn maturing in 90 to 95 days. This makes it a very desirable corn for sections where the time between the late and early frosts is short. The ears set 3 to 4 feet above the ground, are of medium size, average 7 to 91,6 inches long and carry 12 to 14 rows of grain. The kernels are shallow and have a light reddish color with a copper rellow spot in the crown. The stalks grow 5 to 7 feet high and are very thin and leafy. It is, therefore especially well adapted for fodder and bundle feeding but on account of the size of the

cob and its shallow kernels it is not considered a husking corn. write for general quantity prices or submit list of your requirements for special quotations.

\section{Golden King}

Golden King is an early dent corn, being an improved type of Swadles. It matures in 90 days and is well adapted to short seasons and dry lands. The stalks grow to a medium height with ears about three feet from the ground. The ears are medium sized, about 10 inches long. The grains are deep and broad, light jellow color merging to pale yellow at the cap. The cob is white. It makes a good husking com and is very desirable for whole grain feeding.

Prices, not prepaid: 1 lb., $15 \mathrm{c}$; 5 lbs, $50 \mathrm{c} ; 10 \mathrm{lbs} ., 80 \mathrm{c} ; 25 \mathrm{lbs}, \mathbf{\$ 1 . 5 0}$ Please write for general quantity prices or submit list of your requirements for special quotations.

\section{Reid's Yellow Dent}

Reid's Yellow Dent bears the name of its oririnator, James I Reid, of Illinois who many jears aro fired a t5pe that experts have failed to change for the better. It recuires about 110 dars to mature and should change for the better. It requires about 110 dars to mature and should subject to early frosts. The ears are large, averaging 10 to 11 inches in length, slowly tapering, and have a well rounded butt. The grains are jellow, very deep and closely packed on a small cob, the tip and butt of which they almost entirely corer. The leaves and stalks of rapidly becoming the most popular all-around purpose corn that can be grown. 


\section{Western Seed Corn}

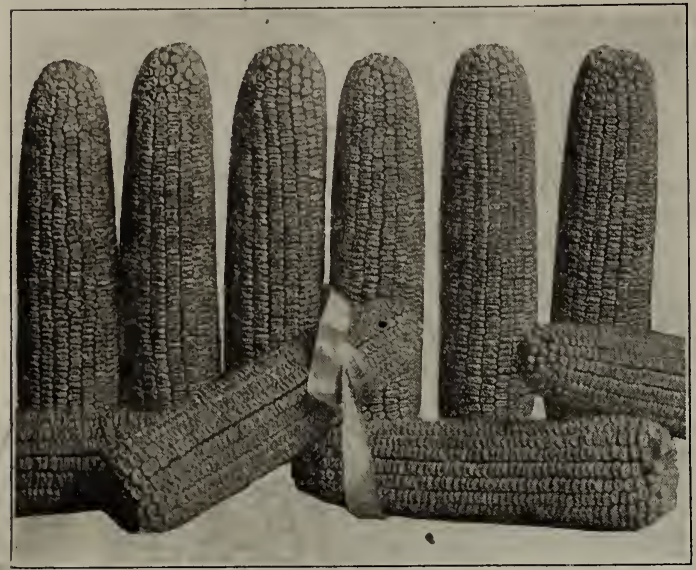

King of the Earliest.

\section{Pride of the North}

Pride of the North is a good variety of extra early yellow dent corn that originated in Northern Iowa more than thirty years ago. It matures in eighty to ninety days. The ears are set low, about one-third of the length of the stalk above the ground. They are medium to small sized, with deep yellow kernels set, solidly on a small bright red cob. Two or more good, well developed ears are frequently found on a single stalk and sometimes there will be three to four stalks to the hill. The stalks are small, well proportioned, short jointed and leafy. Pride of the North withstands drought with credit and is very popular for early feed or for late planting.

Prices, not prepaid: 1 lb., 15c; 5 lbs., 50c; 10 lbs., 80c; 25 lbs., $\$ 1.50$. Please write for general quantity prices or submit list of your requirements for special quotations.

\section{King of the Earliest}

King of the Earliest is an early yellow dent corn that matures in 90 to 95 days. As it withstands adverse conditions to a marked degree, it is very suitable for early planting and can be safely planted as far north as any dent corn. The ears are medium sized, 9 to 10 inches long, with 18 to 24 rows of kernels. The cob is small. The grains are deep somewhat rough, and of a deep yellow color and closely set on the cob. The stalks grow to a good height, are small and leafy. The ears set about four feet from the ground.

Prices, not prepaid: 1 lb., 15c; 5 lbs., 50c; 10 lbs., 80c; 25 lbs., $\$ 1.50$. Please write for general quantity prices or submit list of your requirements for special quotations.

\section{Calico}

Calico is a medium early, mixed dent corn maturing in about 100 days. The ears are large, 9 to 12 inches long and average twenty rows of grain but the cob is small. The kernels are variegated being speckled cr mottled red, white, and yellow. The stalks are very speckled or mottled red, white, and yellow. The ears are carried leafy and attain a height of six to eight feet. The ears are carriedcient feed and it is relished by stock.

Prices, not prepaid: 1 lb., 20c; 5 lbs., 75c; 10 lbs., 90c; 25 lbs., $\$ 1.85$. Please write for general quantity prices or submit list of your requirements for special quotations.

\section{Hickory King}

Hickory King is a very long season variety of white dent corn requiring at least 120 days to mature and for this reason is only recommended for planting in southern districts. It grows very tall. The ears are large, set about six feet from the ground with 16 to 18 The ears are large, set about six feet from the ground

rows of large, deep, broad kernels. The cob is white. $\$ 1.25$. Please write for general quantity prices or submit list of your requirements for special quotations.

\section{Hartner's Rainbow Flint}

This is an early maturing corn and is very desirable for dry lands and short seasons. It is a flint, resembling White Australian in habit and size of kernels. The grains are variegated and highly colored. Having had a long maturing season this Fall, we expect to be able to furnish good seed of high germination. This is not possible every year.

possible every year. Prices, not prepaid: 1 lb., $15 \mathrm{c} ; 5$ lbs., $50 \mathrm{c} ; 10 \mathrm{lbs}$., $90 \mathrm{c}$. Please
write for general quantity prices or submit list of your requirements for special quotations.
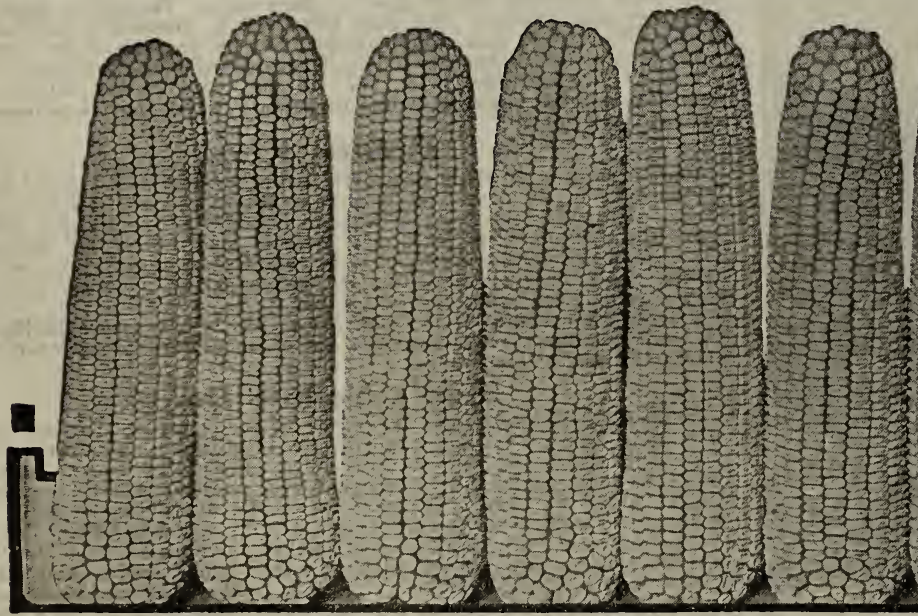

\section{Squaw}

Squaw corn is supposed to be a mixture of the various sorts once grown by North Dakota Indians. It is sometimes called Blue Squaw. It is very early, requiring not over 90 days to mature and is a very vigorous plant. The ears are small, averaging about eight inches long, set close to the ground, and carry eight rows of grain. The kernels are somewhat shallow, rounded, smooth, and flinty and are a mixture of blue, white, and yellow colors. Squaw corn is adapted for hog or sheep pasture. It yields much better than would be expected from such a short plant. In sections where the growing season is short it is the only kind of corn that will make grain.

Prices, not prepaid: $1 \mathrm{lb}$., 20c; 5 lbs., 75c; $10 \mathrm{lbs}$, 90c; 25 lbs. \$1.85. Please write for general quantity prices or submit list of your requirements for special quotations.

\section{Gehu Flint}

Gehu is a yellow, dwarf, flint corn that grows 4 to 6 feet high and matures in 80 to 90 days. It is not generally used as a husking corn as the ears set close to the ground, but this feature makes it very desirable for early hogging down. It usually produces more than one ear to the stalk. The ears are 5 to 7 inches long, $4 \frac{1}{2}$ to $51 / 2$ inches in circumference and very tapering. The kernels are shallow, smooth, hard and of an orange or dark yellow color. It is the earliest yellow corn.

Prices, not prepaid: $1 \mathrm{lb} ., 15 \mathrm{c}$; 5 lbs., 50c; $10 \mathrm{lbs}, 80 \mathrm{c}$. Please write for general quantity prices or submit list of your requirements Write for general quan
for special quotations. 


\section{Western Field Peas and Vetch}

\section{Field Peas}

No other grain crop, except perhaps oats, can be devoted to so great a variety of uses. The grain is possessed of a relatively high feeding value, and the same is true of the straw. As a pasture for certain kinds of livestock, peas may be made to serve an excellent purpose. The value of the crop for soiling and fodder uses is excelled rore is no kind of liveonis by to which peas cannot be fed to advantage.

\section{San Luis Valley Peas}

This variety is also called Colorado Stock Peas, and has been grown for years in the San Luis Valley in Colorado. The stockgrowers in these regions found them valuable for fattening hogs and sheep. The custom was to allow the stock to graze on the pea fields eating the vines and seed. Pea fed pork is much Recent years have ceen a big demand for these peas as a food and large quantities have been shipped to and large

This is and foreign market It produces a large quantity of vines, that make a fine hay, and the is very fattening for sheep, hogs, etc. When sown for seed about 80 pounds per acre, but for hay it may be sown as late as July, when 100 pounds

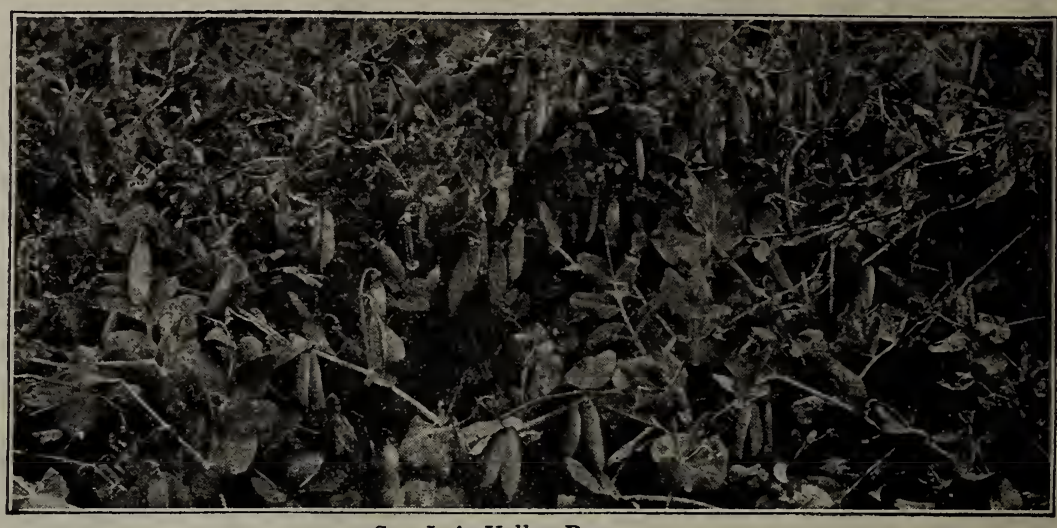

San Luis Valley Peas.

\section{Whip-poor-will Cow Peas}

Sometimes called Shinney Peas. The Whip-poor-will is more largely grown than any other cow pea, probably because of its lon vine, usually six feet long, and because of its large yield of both hay and peas. It matures early, makes an upright growth, makin it easy to cut Has brown speckled seeds that are easily threshed. Recommended where an early variety is wanted.

Prices: Lb., 20c; 5 lbs., 90c; 10 lbs., $\$ 1.50 ; 25$ lbs., \$2.75. Please write for general quantity prices or submit list of your requirements for special quotations.

\section{Sand or Hairy Vetch}

SOUTHERN BLACK-EYED PEAS most extensively grown of all Black-Eye varieties. The seed resembles a bean in shape. They make a large vine growth and are an excellent soli improver. The peas mand during the Winter. They are also used green during the Summer. Many people plant Southern Blackeye Peas in the garden

ye Peas in the garden. eral quantity prices or submit list of your requirements for special quotations.

\section{Canada Field Peas}

Are one of the very best soiling crops for the North. They are sometimes grown alone, but the most satisfactory dairy results comes from sowing with oats, rye or barley. They make good ensilage, and rom for either freen or they are an admirable food either gren in the Spring, and will be ready to cut in May or June.

Prices: Lb. 20c; 5 lbs, 90c; 10 lbs, \$1.50; 25 lbs., \$2.75. Please write for general quantity prices or submit list of your requirements for special quotations.

Alfalfa, clovers, soy beans, vetches, peas, beans, cow peas, peanuts, and other legumes should always be inoculated with Nitragin. The lack of necessary bacteria in the soil is often the cause of a poor legume crop-a weak start-or a total failure. See page 87
Winter Vetch is a mighty fine crop to sow in the Fall just as soon as the crops have been harvested and on up to November first. Vetch. being a leguminous plant like alfalfa and peas, gathers nitrogen from the air and stores it in the roots, thereby adding plant food for the idle months this crop is slowly but surely enriching the soil at no trouble or expense to the grower. The soil is kept in better condition for Spring planting and is freer from weeds. If the Winter and Fall season has been inclined to be warm and open a good growth will have been obtained and there will be a big quantity of vegetation to plow under in the Spring. This green manure supplies moisture as well as food to the Spring crop and many times gives it a start that puts it through the dry season. If a good inoculation is applied to vetch seed the yield is increased.

Prices: Lb., 30c; 5 lbs., $\$ 1.25$; 10 lbs., \$2.25. Please write for special quotations. other plants that take all of their food from the soil. Thus, during general quantity prices or submit list of your requirements for

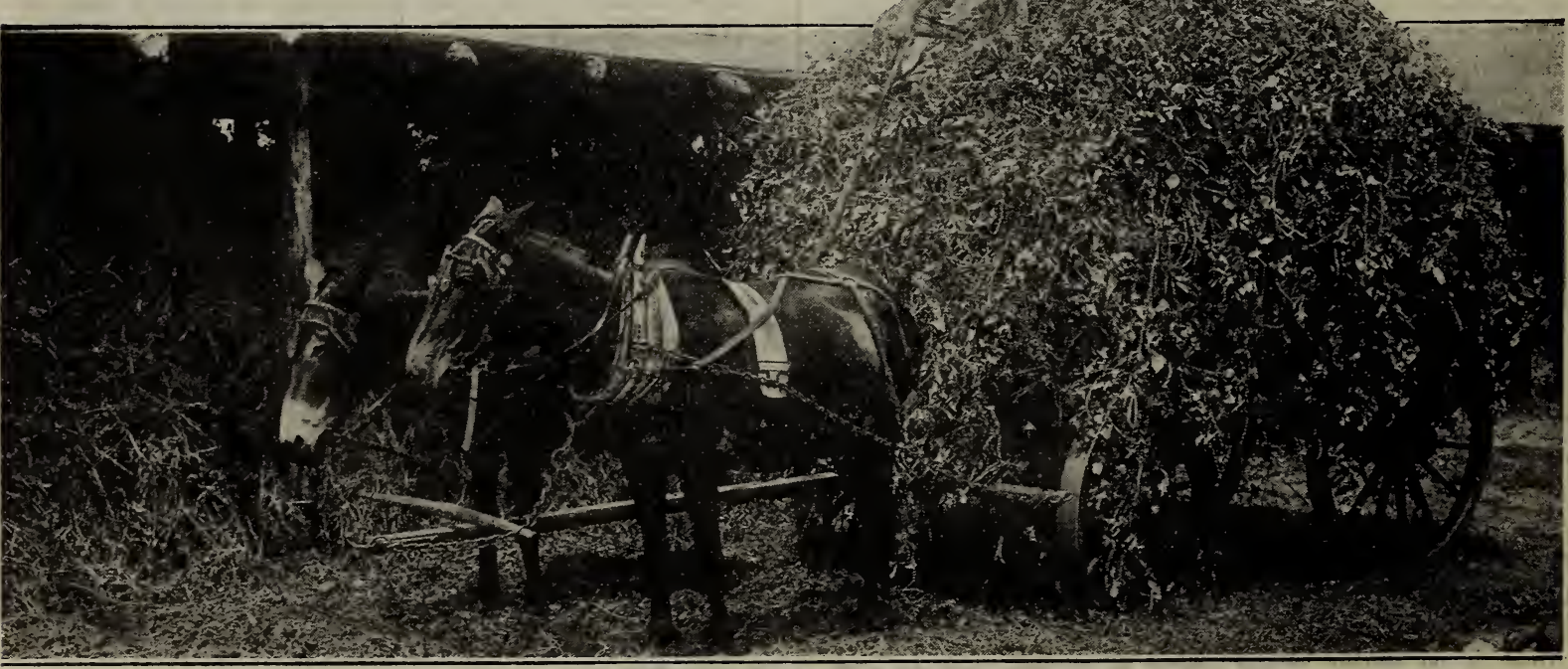

Whip-poor-will Cow Peas. 


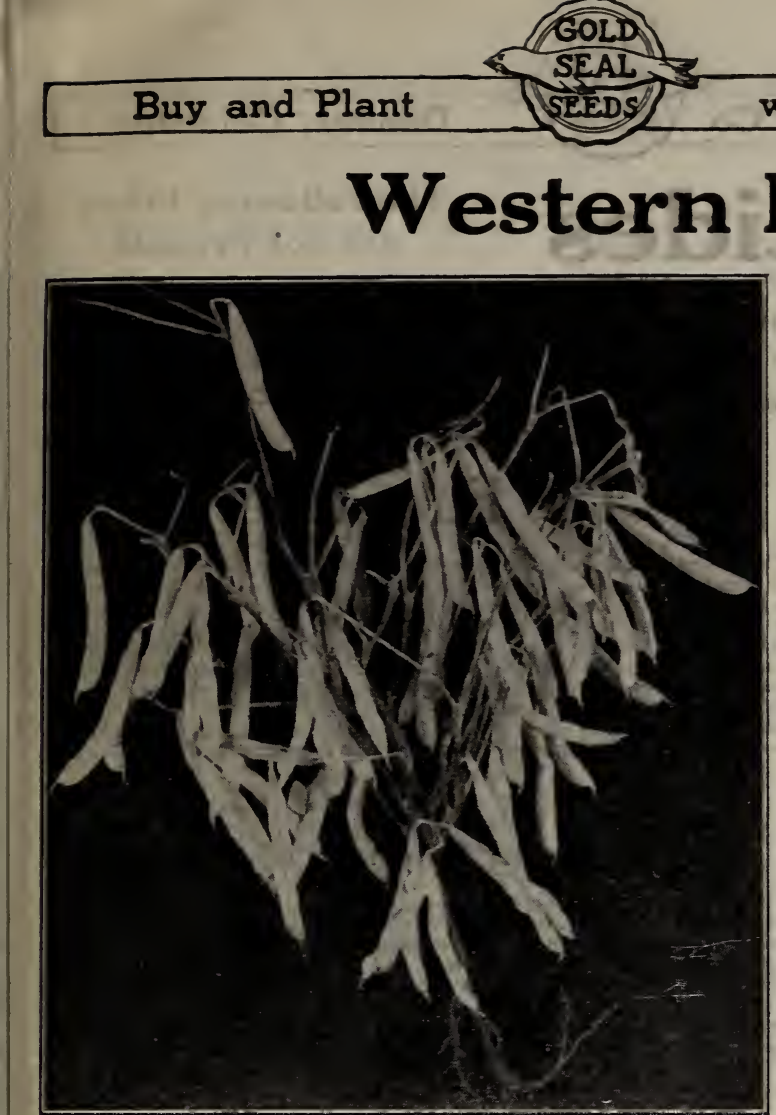

Navy Beans.

\section{Pinto Beans (Mexican)}

The leading commercial bean of the West. The Pinto Bean will grow on dry land and yields as high as 1,100 pounds per acre have been reported, while on irrigated land, 2,500 nounds have been secured from one acre. It is easily grown and requires little attention. There is now an established demand from Eastern and Southern markets for this variety. Our seed stock is select, hand picked and grown in Colorado on dry land.

Prices: Lb., 20c; 5 lbs., 75c; 10 lbs., \$1.25. Please write fort general quantity prices or submit list of your requirements for special quotations.

\section{Stock Beans}

\section{Early Soja Beans}

A valuable forage plant, little affected by heat and drought. Is one of the most nutritious of all vegetable products. It will produce from 20 to 30 bushels to an acre. For pasturing or feeding as green fodder it is very valuable; also a good fertilizer.

Prices, 1 lb., $25 \mathrm{c} ; 5$ lbs., $\$ 1.00 ; 10 \mathrm{lbs}$., \$1.75. Please write for general quantity prices of submit list of your requirements for special quotations.

\section{Ito San Sojas}

A very satisfactory variety to grow in a short season. Produces seeds fairly well, and matures in 95 to 100 days. Branches well, so as to be very easily harvested. The plants are of medium size, averaging 25 to 30 inches in height. Will mature as far north as Wisconsin and Michigan.

Prices, 1 lb., 25c; 5 lbs., $\$ 1.00 ; 10 \mathrm{lbs}$., \$1.75. Please write for general quantity prices or submit list of your requirements for special quotations.

\section{Hollybrook Early Sojas}

Make a quicker growth and mature their crop two weeks earlier than the Mammoth Yellow Soja It makes a large yield both of fora earlier than the Mammoth Yellow Soja. It makes a large yield both of forage and peas and acquisition. Sown as a forage or hay crop it is much easier to cure and handle, and makes even a more nutritious crop than cow peas.

Prices, Ib., 25e; 5 lbs., \$1.00; 10 lbs., \$1.75. Please write for general quantity prices or submit list of your requirements for special quotations.

\section{Inoculate Your Beans with Nitragin}

Alfalfa, clovers, soy beans, vetches, peas, beans, cow peas, peanuts, and other legumes should always be inoculated with Nitragin. The lack of necessary bacteria in the soil is often the cause of a poor legume crop-a weak start $\rightarrow$ or a total failure. See page 87 .

\section{Red Kidney Beans}

Will produce crop of first class beans and are a success in the They are excellent canners and richly flavored. They are tion is useless. Their habits of growth are similar to the pinto. is quite a large local demand for the dry beans,

Prices: Lb., 25c; 5 lbs., $\$ 1.00$; 10 lbs., \$1.75; 25 lbs., \$4.00. lease write for general quantity prices or submit list of your re

\section{Broad Windsor Beans}

These beans are hardy and can be treated in about the same man They should be planted in rows from twelve to eighteen eans are very much in favor in Europe, where they are cooked hile green; but also the dried beans are much used in the kitchen the pods, while quite young, are eaten. The beans have an

Prices, (Hand Picked): Lb., 25c; 5 lbs., \$1.15; 10 lbs., \$2.25.

\section{Red Mexican Beans}

These are similar in size and shape to the Pinto Bean and in their mand for these beans for Chili. They are excellent cookers. A

Prices: Ib $25 \mathrm{c}^{\circ} 5$ lbs $\$ 1,00,10$ lbs, $\$ 175$ Please rite for quantity prices or submit list of your requirements for pecial quotations.

\section{Navy or Pea Beans}

The best known white bean in the world. More Navy Beans are than all other varieties combined. They always comman

the other varieties, except Limas. large yields when grown under irrigation.

Prices: Lb., 25c; 5 lbs., $\$ 1.00 ; 10$ lbs., \$1.75. Please write for Great Northern or Large White Marrowfat

This bean is similar to the Navy and often sold as such. It is avy would fail. It is a heavy yielder and the beans have a very e favor when ccoked or baked. This variety is in great demand as Wean for Winter use and will give satisfaction on either dry or

Prices, 1b., 25c: 5 lbs. \$1.00; 10 lbs., \$1.75. Please write for eneral quantity prices or submit list of your requirements for special quotations.

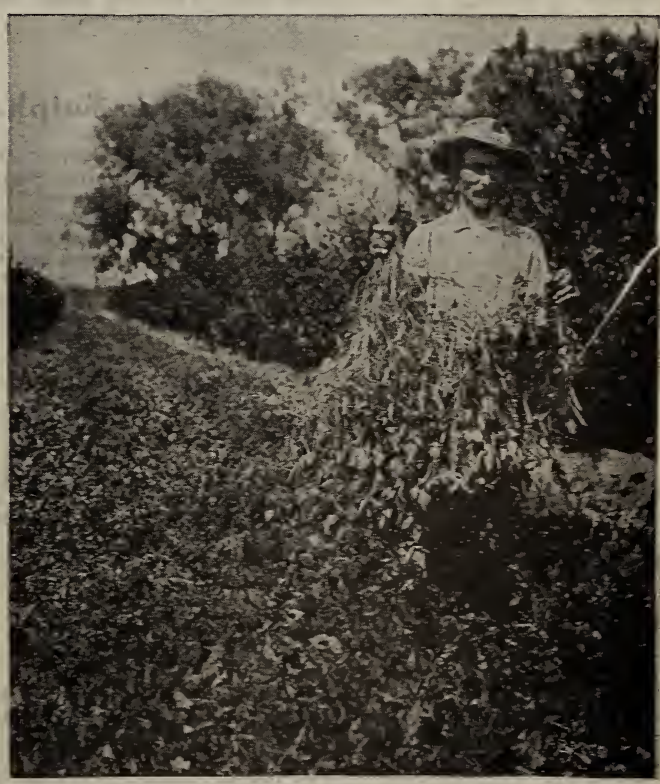

Soja Beans. 
Poisons Cannot Be Sent by Mail
Insecticides

The Following Prices are not Prepaid

Spraying materials may be divided into three general classes: Poisons, Contact Solutions and Fungicides. The first two are Insecticides, while the third is used for protection against infection by fungous diseases.

\section{The Poisons}

The poisons are used against surface chewing or biting insects, such as most caterpillars and leaf beetles, potato bugs, tomato and such as most caterple codling moths, bud-worms, fruit worms, etc. tobacco worms, apple codling moths, bud-worms, fruit worms, etc. No spraying material is a the leaves and remain in the form of a thin film. are sprayed upon the leaves and remain in the form of a thin film, or coating. The poisons act by being taken into the stomachs of
the insects while eating. In this group come Paris Green, Arsenate of Lead.

\section{Powdered Arsenate of Lead}

is an effective insecticide for leaf eating insects on tender foliage Prices, not prepaid: $1 / 2$ lb., 25c; $1-1 b$. carton, $40 \mathrm{c} ; 4-1 \mathrm{~b}$. bag, $\$ 1.25$. Complete insecticide catalog and prices on larger quantities on application.

\section{Paris Green}

is a strong effective poison for leaf eating insects. Prices, not prepaid, $1 / 4-1 b$. fibre carton, 20c; 1-lb. fibre carton, 50c; 4-lb. metal containers, \$1.95. Complete insecticide catalog and prices on larger quantities on application.

\section{The Contact Solutions}

The contact solutions are used to combat sucking insects, such as plant lice or aphis, thrips, leaf-hoppers, apple red bugs, and the various kinds of scale. As these insects obtain their food by inserting tubes or bristles under the surface and sucking the plant juices, they will not be affected by the poisons. Fortunately this class of insects have generally very soft bodies, and the contact solutions are insects have generally very soft bodies, and the cor clogging up their designed to act upon these by caustic action, or by clogging up their breathing tubes. They have no effect on the hard exteriors of the insects mentioned in the preceding paragraph. These materials must be applied very thoroughly so that each insect will be touched by a
particle of spray. In this group come Fish Oil Soap, Dry LimeSulphur, Tobacco Solutions and special Tobacco Dusts.

\section{"Black Leaf 40" Nicotine Sulphate}

This is splendid for use as a contact spray to kill green and wooly aphis, plant lice, red sniders, cabbage aphis and onion thrips. It is especially effective for the green aphis on sweet peas, roses, and apple trees, as it kills the insects as soon as it touches them; but if apple trees, as it kills the insects as soon as the leaves, flowers or used according to directions does not injure the leaves, flowers or fruit. Spray apple trees when the tips of the buds are green, $\% / 4$ pint to 100 gallons of water. For sweet peas and roses, use 40 drops of $35 \mathrm{c}$; $1 / 2 \mathrm{lb}$., \$1.25; 2 lbs., \$3.25; $10 \mathrm{lbs.}$. \$13.50.

\section{Tobacco Dust}

Finely ground Tobacco Dust is a very effective weapon against Aphis and Lice on all plants. Splendid fertilizer also and preventative for insects in the ground and around roots. 1 lb., 10c; 3 lbs. $25 \mathrm{c} ; 100$ lbs., $\$ 5.25$.

\section{Fish Oil Soap}

Fish Oil Soap is excellent as a wash for keeping the trunks of trees bright and free from insects, for it not only kills the insects trees bright and free from insects, for it not only kills the insects on the surface, but it penetrates into the crevices and destroys eggs and larvae. It is recommended for use against many varieties of the Mealy Bug. Makes an excellent summer spray. 1 lb., 25c; 5 lbs., $\$ 1.00 ; 10$ lbs., $\$ 1.75$.

\section{The Fungicides}

The Fungicides are used to give protection against infection by such fungous diseases as potato blight, grape mildew, apple scab. strawberry leaf-spot, peach scab, etc. They act mainly by preventing the fungus "spores" (which correspond to the seeds of higher plants) from germinating when they alight on protected foliage. plants) from germinating when they alight on protected foliage. As all fungicides are preventives and not cures, do not wait until a disease, which you know is prevalent in the neighborhood, actually establishes itself on your trees or crops, before applying, as then it
is in many cases too late. In this group come Bordeaux Mixture in is in many cases too late. In this group come Bordeaux Mixture in
powdered form, Dry Lime-Sulphur, Blue Vitriol and Formaldehyde.

\section{Blue Vitriol or Sulphate of Copper}

This is a sure preventative of smut in your grain and when the seed goes through a solution of vitriolized water the crop produced therefrom will be clean and free from smut. We handle only the crystal form ready to dissolve and use. One pound of Blue Vitriol dissolved in 20 gallons of water makes a suitable solution for treating 30 bushels of wheat or barley for smut. It is not so handy to prepare for use as Formaldehyde but it is somewhat cheaper and we prepare for use as Formaldehyde but it is somewhat cheaper and we
believe more effective. A mixture of five pounds of Blue Vitriol and believe more effective. A mixture of five pounds of Blue Vitriol and
five pounds of lime added to 60 gallons of water is very effective for five pounds of lime added to 60 gallons of water
celery. 1 lb., 20c; 5 lbs., 85c; 10 lbs., $\$ 1.50$.

\section{Formaldehyde}

It is of pronounced efficiency in destroying disease germs affecting both animal and plant life and is successfully employed as a preventative of such fungous diseases as potato scab, onion and grain smuts, musty corn and other affected seeds, damping off of seedlings, club root of roses, etc., for the restraining of decay in vegetables, fruits, etc and as an antiseptic wash and spray for bark diseases, canker and wounds in trees. The dintion fpray for bark diseases, canker (1 pint) formaldehyde to 15 or 20 gallons of water. Formaldehyde is put up in pint or pound bottles and this quantity added to 40 gallons of water will treat 30 bushels of wheat or barley, or 40 bushels of oats for smut or 60 bushels of flax for wilt. 1-lb. can, 55c; $5-1 b$, cans, $\$ 2.50$.

\section{Copper Carbonate}

Experiments by the extension service of the Colorado Agricultural College show that Copper Carbonate is very efficient for the control of Bunt or Stinking Snut of wheat. As it contains a higher per cent of copper than prepared formulas, it is not necessary to use so much. Two or three ounces of 52-54 per cent Copper Carbonate per bushel of grain is sufficient. The value of Copper Carbonate is determined by its metallic Copper content. Do not be misled into buying inferior carbonate. Copper Carbonate with less metallic Copper can be bought for less. 5 lbs., $\$ 1.75 ; 10$ lbs., $\$ 2.80$.

\section{Bordeaux Mixture}

For fungous diseases. Prices, not prepaid: 1/2-1b. carton, 25c: 1-lb. carton, 40c; 4-lb. bags, $\$ 1.40$. Complete insecticide catalog and prices on larger quantities on application.

\section{Dry Lime-Sulphur}

For dormant spraying against scale. Prices, not prepaid : 1 lb., 30c; 5 lbs., $\$ 1.30$; 10 lbs., $\$ 2.50$. Complete insecticide catalog and prices on larger quantities on application.

\section{Devoe's Double Duty Spray}

This is a combination spray in powdered form and will be available this year. Write for full description and prices. 


\section{Devoe "Sure-Noxem" \\ INSECTICIDE AND FUNGICIDE}

For use on Cabbage, Cauliflower, Tomato Plants, Cucumber Vines, Melon Vines, Currant Bushes, Gooseberry Bushes, and other vegetables and shrubs of many kinds.

Not prepaid, 1-lb. sifter top can, 20c; 5-lb. bag, 75c. Write for prices on 100-1b. metal drums.

\section{Hammond's Slug Shot}

This is one of the oldest and most reliable insecticides on the market. It comes in fine powdered form and is easily distributed by dusting, or can be mixed with water and used in a spray.

It is very effective in killing currant worms, potato bugs, cabbage worms, chicken lice, slugs, etc.

$1 \mathrm{~b}$, put up in can with perforated top $\ldots \ldots \ldots \ldots \ldots \ldots \ldots \ldots . \$ \ldots 0.20$ 5 lbs., put up in packages.............................. 10 lbs, put up in packages

\section{Nicofume Liquid}

This is a highly refined solution of "free" nicotine, containing 40 This is a highly reflis solution of "freth for spraying and fumiper cent nicotine. This may be used both for spraying and fumigating. It is an effective remedy for green Aphis and other insects rate of 1 to 2 teaspoonfuls to the gallon of water. Directions on each package. 1/4 1b., 75c; 1 lb., $\$ 2.00 ; 4-1 b$. tins, $\$ 7.00 ; 8-1 b$. tins, $\$ 13.00$, by express or freight.

\section{Nicofume Paper}

By using this paper greenhouse men will find the destroying of lice, etc., very easy. It is a slow-burning paper, saturated with nicotine and is not at all injurious to tender plants. 24 sheets in

\section{Powdered Sulphur}

It has been proven and so recommended by the University of California that if you sulphur your grape vines and orchards six times fornia that if you sulphur your grape vines and orchards six times they will not be affected by Mildew or Red Spiders. Sulphur is a good fertilizer and beneficial results will be obtained if you incorIt will help to exterminate cut worms.

Our powdered Sulphur or Flour of Sulphur is very pure. Per lb., $10 \mathrm{c} ; 100$ lbs., $\$ 5.00$.

\section{Hydrated Lime}

\section{Finels Polrerized}

Lime is a wonderful element for sweetening soils, correcting acid Lime is a Through the use of lime, a much thicker turf of Blue Grass can be obtained. Scatter light and evenly 2 to 4 pounds per 100 square leet of lawn.

Price, not prepaid: 10 lbs., $35 \mathrm{c}$; 50 lbs., $\$ 1.00$.

\section{Common Sense Rat Exterminator}

Destroys rats under all conditions. They eat it in preference to any food. No stench. It dries up the carcass, leaving only the pelt. as so little is required. Price, 30c, not postpaid.

\section{Moore's Prepared Poison Grain}

Certain and speedy destruction to ground squirrels, gophers, prairie dogs, rats, mice, etc., and easy to use; cheap and will kill ten where traps and other devices get one. All experienced pest fighters find poisoning the best method, but it must combine three points. It must be something they will eat, thoroughly poisoned and placed where

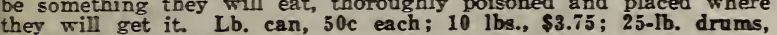
$\$ 7.50$, not postpaid.

\section{Gas Ball Rodent Killer}

Is a ball which, when lighted and rolled down into the burrow, pours Is a ball which, when lighted and rolled down into the burrow, pours forth a deadly poisonous gas that carries death to any living thing in the burrow. Aithough it means absolute destruction to rodents, injured or endangered by its use. It is non-explosive, does not deteriorate with age and is cheaper than similar material on the marset. It kills the squirrel, gopher and prairie dog at small expense and no danger to stock and is non-poisonous to handle and a sure
killer. Dozen, 60c; carton of $125, \$ 3.50$, not prepaid. Write for prices on larger quantities.

\section{Grasshopper Poison Mash}

This can be used effectively and is one of the very best methods for controlling a grasshopper plague
25 lbs. bran
1 lb. Paris Green.
3 gal. water 2 arts cheap syrup

A little vinegar may be added to give the mixture an odor.

Mix thoroughly.

The above quantity of materials properly strewn, is sufficient to sow around 5 or 6 acres and will completely cover 3 acres. This poison should be sown broadcast where the hoppers are most abundant. Do not drop in piles.

Paris Green is just as effective as White Arsenic. Set out in May, June or July.

\section{Mouse Seed} Kills mice without bait, traps or muss. It is safest to use where
there are children or pets. The seeds are unpleasant to the taste but are attractive to mice. Small package, $25 \mathrm{c}$.

\section{High Grade Fertilizers}

BONE MEAL. Contains the essential elements that grass requires and is a very efficient fertilizer. It may be broadcast as a top dressing at any time with beneficial results.

Quantity Required. For lawns, pastures and hay lands, $10 \mathrm{lbs}$. to 200 sq. ft. For trees and vines, 2 to $4 \mathrm{lbs}$. each. For garden crops, 1 ton per acre harrowed in. For rose beds, pot plants, etc., 1 part to 50 of soil. 4 lbs., $25 \mathrm{c} ; 10$ lbs., $50 \mathrm{c} ; 25 \mathrm{lbs} . \$ 1.00 ; 50$ lbs., $\$ 1.60$ 100 lbs., $\$ 2.75$.

VEGETABLE FERTILIZER. This fertilizer is especially prepared and highly recommended for all vegetable crops. It gives most excellent results, on peas, beans, cabbage, melons, and tomatoes. Use 400 to 500 lbs. per acre. A good substitute for stable manure, or can be used in connection with it. This also makes an excellent beet
fertilizer. 10 lbs., $65 \mathrm{c} ; 25$ lbs., $\$ 1.00 ; 50$ lbs., $\$ 1.50 ; 100$ lbs., $\$ 2.50$

LAWN DRESSING. It contains just the right proportions of the elements which nourish and feed grass into a luxuriant growth. It produces a rich green color and insures a permanent evenness ove the whole surface of your lawn. 4 lbs, $25 \mathrm{c} ; 10$ lbs, $50 \mathrm{c} ; 25$ lbs $\$ 1.00 ; 50$ lbs., \$1.50; 100 lbs., \$2.50.

SHEEP MANURE. Analysis: Ammonia, 21/2 per cent; Phosphoric Acid, 11/2 per cent: Potash, 11/2 per cent. This is one of the most complete fertilizers known to science. It can be used separately or in combination with the special purpose fertilizers. Sheep Manure is considered the best fertilizer for lawns and truck gardens, and contains no strong odor that usually accompanies animal fertilizers, $\$ 12.00$; ton, $\$ 20.00$, at warehouse.

NITRATE OF SODA. A fertilizer very quick in action and used for the nitrogen it contains. It creates rapid growth, is odorless, rery quickly and entirely soluble. It should be applied only when the plants are above ground, usually in combination with other
chemical fertilizers. Very good for sweet peas, etc. 1 lb., $15 \mathrm{c}$; $10 \mathrm{lbs}$, $\$ 1.20 ; 100 \mathrm{Ibs}$., $\$ 8.50$.

FLORA FERTILIZER. There are three elements which we must heavily draw upon, of the many which are necessary to maintain plant life, namely: Potash, Phosphoric Acid, and Nitrogen. Flora Fertilizer is guaranteed to contain these three elements as follows: Potash, 6 per cent; Phosphoric Acid, 11 per cent; Nitrogen, 4 per cent. It is odorless and one-fourth as much Flor Fertilizer is re quired as other Commercial Fertilizers. 2-1b. can, 35c; 5 lbs., 70 c; 25-lb. sack, $\$ 2.00$, not prepaid.

\section{Stim-U-planT}

Growers of fine flowers, shrubs, and vegetables for the best markets and for exhibition, fertilize and stimulate them frequently, a little at a time An excellent fertilizer for this purpose is Stim-UplanT, an odorless, highly concentrated plant-food, in tablet form, with guaranteed chemical analysis of 11 per cent nitrogen, 12 per cent phosphoric acid, 15 per cent potash. The proportions are accurate, there is no wasted filler, and in this form you apply plan food exactly when and where and as needed.

Order Stim-U-planT tablets with your seed and plant order. Trial size, $15 \mathrm{c}$; small size, $25 \mathrm{c}$; 100 tablets, $75 \mathrm{c} ; 1000$, $\$ 3.50$.

\section{Nitragin}

Larger crops in field and garden if you use Nitragin, the Improved Soil Inoculator. It restores and maintains soil fertility. Alfalfa, clover, sorghums, vetches, peas, beans, cow-peas, peanuts and other legumes should always be inoculated with Nitragin. The lack of necessary bacteria in the soil is often the cause of a poor legume crop-a weak start-or a total failure. Nitragin now comes in bushel sizes instead of acre sizes. This means a lower cost per acre.

Prices below cover all legumes except Soy Beans and Cow Peas $1 / 4$ bushel size.......................... \$0.40, postage $\$ 0.04$ $1 / 2$
1
1
bushel

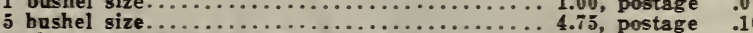
Garden size (for $S$ weet Peas, Peas and Beans)... .20, postage $\quad .02$

Prices on Soy Bean and Cow Pea Culture.

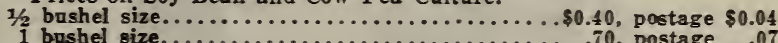

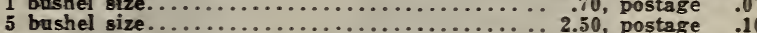

IMPORTANT-When ordering always name the seed you wish to inoculate.

Postage need not be added for Nitragin if there are other items on your order.

\section{Army or Cutworm Bait}

No spray is effective against army worms or cutworms. To combat these, poison hait must be resorted to. One good formula is to stir 2 quarts of cheap molasses dissolved in $31 / 2$ quarts of water into mixture of $20 \mathrm{lbs}$. of dry bran and $1 \mathrm{lb}$. of Paris Green. Scatte in fields after sundown, taking care not to allow mixture to fall on plants. 


\section{Planet Jr. Farm and Garden Tools}

A Complete Catalog Sent on Request.

Space will not permit us to fully list and describe the entire Planet Jr. Line of Garden Tools. The few that we are showing below are the best known of this world famous line. However, we will gladly send a complete Planet Jr., Catalog free of charge, on request. There has been another reduction in prices this year. We are selling at factory price, f. o. b. Denver.

\section{No. 4 Planet Jr. Hill and Drill Seeder,} Wheel Hoe, Cultivator and Plow

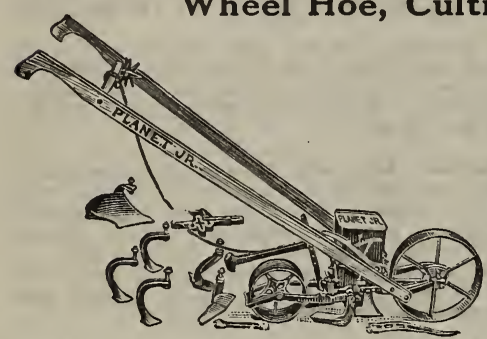
$\$ 18.00$

This accurate, easy running tool sows all garden seeds from smallest up to peas and beans in hills, $4,6,8,12$ or 24 inches apart, or in drills at the proper thickness and depth; rolling down and marking the next row all at one passage. By removing the seeder and substituting the tool frame you have a complete Single Wheel Hoe which plows, hoes, cultivates easily and thoroughly all through the season.

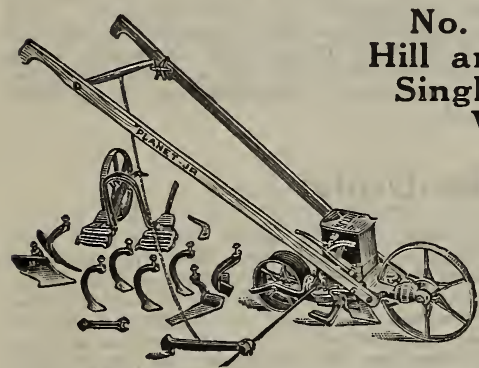

No. 25 Planet Jr. ill and Drill Seeder, gle and Double Wheel Hoe

$\$ 21.50$

Holds $2 \frac{1}{2}$ quarts.

Weight, 61 lbs.

This is a splendid combination for a family garden, onion grower or large-scale or large-scale gardener. As a Seeder it is the same as the No. 4 and to straddle rows. Hoes work close without injuring plants; cultivator teeth and plows do thorough work. Cutting tools specially hardened. Two acres a day can be worked with this tool.

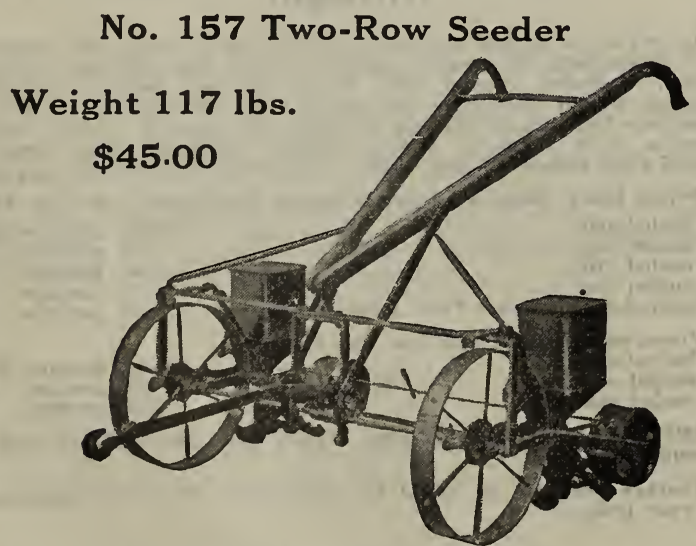

The No. 157 is now equipped with the New Multiple Seeder units which have a capacity of 5 quarts of seed. It is also equipped with a larger drive wheel which sets the frame several inches higher than formerly. This two-row seeder runs so lightly that one man can push it: but for all day work, a man or boy pulling on the front makes the draft extremely light for both. However, a horse is usually used. With the No. 157 you can sow rows from 10 to 36 inches y used. With the No. 157 you can sow rows from 10 to 36 inches of gear for moving from place to place. Saves seed and makes the of gear for moving from
No. 3 Planet Jr. Hill and Drill Seeder

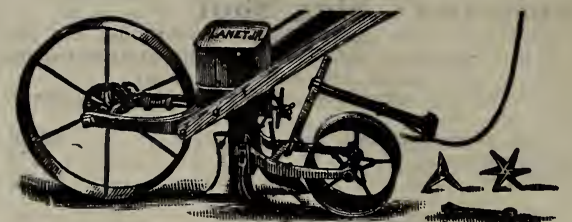

$\$ 17.50$

Holds 3 quarts. Weight, 43 lbs.

A favorite tool with onion growers, market gardeners and seedsmen. Has 15-inch steel driving wheel. The V-shaped opening plow is adjustable for depth and leaves the seed in a narrow line, permitting close, rapid cultivation with wheel hoes, Sows uniformly in mitting close, rapid cultivation with wheel hoes. Sows uniformly in is sufficient to warrant the use of separate seeders and wheel hoes, is sufficient to warrant the use of separate seed
we specially recommend this very popular drill.

\section{Planet Jr. No. 26 Drill Seeder}

This Planet Jr. product has extra substantial, wide tread wheels, front and rear, that run easier and cover more evenly than any machine you have ever seen. It involves new principles in seed dropping and the hopper is detachable, making it convenient for emptying seed. This machine is shaft driven, eliminating the annoy-
ance of loose chains. We recommend it to anyone wanting a real ance of loose chains. We recommend it to anyone wanting a real $\$ 20.00$.

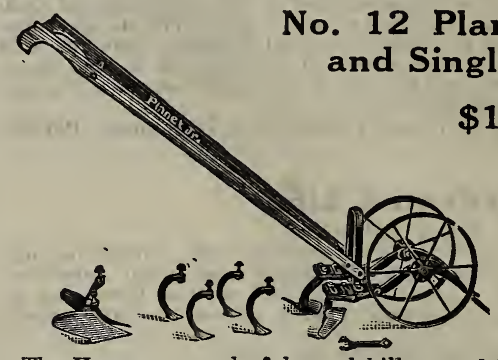
$\$ 10.75$ The Hoes are wonderful weed killers and leave the ground almost level. Cultivator Teeth for deep or shallow work. Plows are valuable for opening furrows, covering or plowing to or from the crop.

No. 13 Planet Jr.

No. 13 Planet Jr., double and single wheel hoe equipped with one pair 6 -inch oil tempered hoes. Weight, $28 \mathrm{lbs}$. Price, $\$ 8.00$.

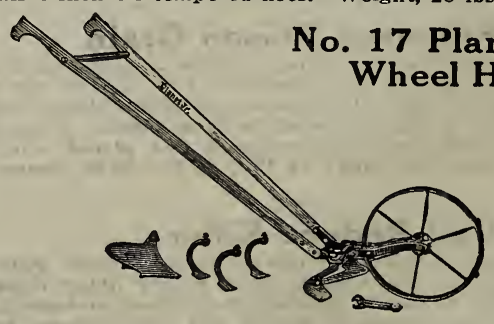

Weight, 33 lbs. 14-inch Steel Wheels A Double and Sin. gle Wheel Hoe in one. Straddles crops till 20 inches high then be worked between the rows with 1 or 2

\section{ning steel wheel. They take the drudgery out} give bigger, better crops. Lasts a lifetime.

No. 17 $1 / 2$ Planet Jr. Single Wheel Hoe

No. 171/2 Planet $\mathbf{J r}$. is equipped with one pair six-inch hoes, three cultivator teeth, oil tempered, and leaf lifter. Weight, 21 lbs. Price, $\$ 6.75$.

No. 18 Planet Jr. Single Wheel Hoe No. 18 Planet Jr. is equipped with one pair six-inch hoes only. Weight, 19 lbs. Price, $\$ 5.75$.

\section{Extras for Planet Jr. Hand Tools}

6-inch Hoes, pair..................................... $\$ 1.30$

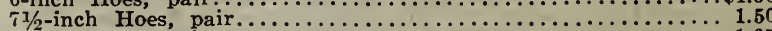

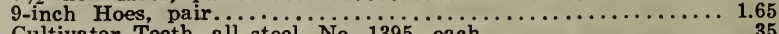
Cultivator Teeth, all steel, No. 1395, each...................35 Plows for single wheel Hoes, each $\ldots \ldots \ldots \ldots \ldots \ldots \ldots \ldots \ldots \ldots . .1 .30$ Plows for double wheel Hoes, pair $\ldots \ldots \ldots \ldots \ldots \ldots \ldots \ldots \ldots, 1.40$

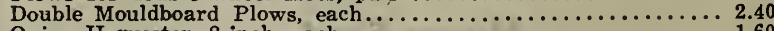

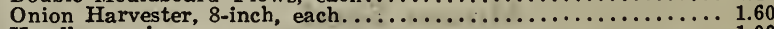
Handles, pair........................................... 1.00 Rakes, three tooth, pair........................................ 1.00

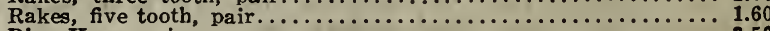

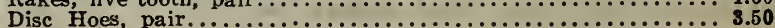




\section{Garden Tools}

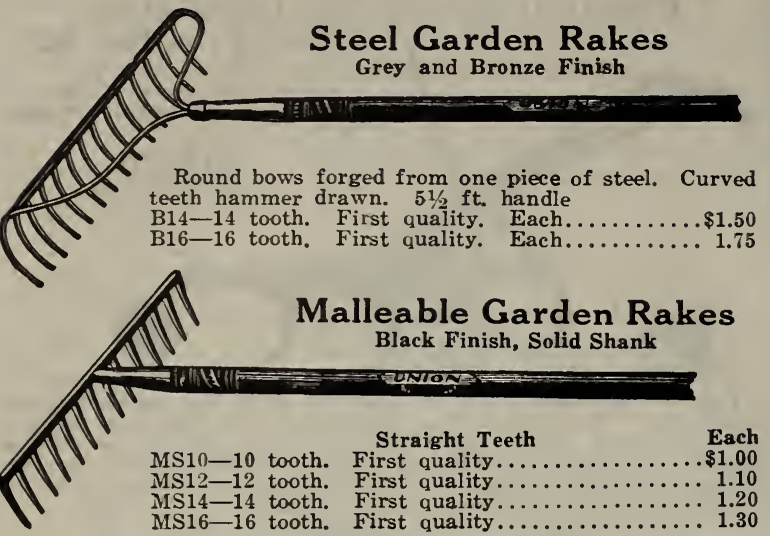

Solid Socket Mortar Hoes

First Quality

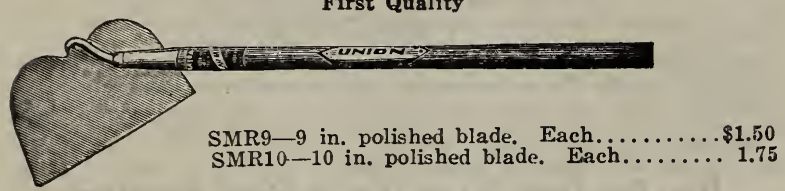

Field and Garden Hoes Solid Socket-First Quality

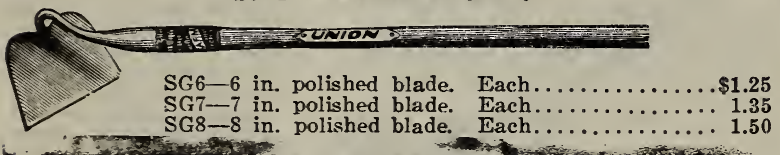

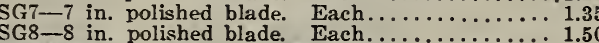
Beet Hoes

Solid Socket--First Quality

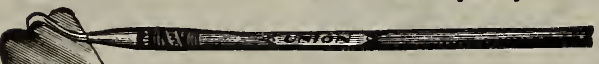

BTH6 6 in. polished blade, solid shank. Each......\$1.00

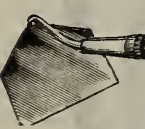

SBT4-4 in. Celery Hoe, $41 / 3 \mathrm{ft}$. handle.......\$1.25 SBT6-6 in. Nurseryman's Hoe, $41 / 3 \mathrm{ft}$. handle. 1.25 SBT7-7 in. Nurseryman's Hoe, $41 / 3 \mathrm{ft}$. handle. 1.35 SBT6-With 18 in. handle................ 1.00

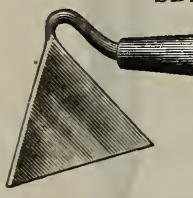

\section{Onion Weeder} OW-3 in. steel blade, bronze finish, 8 -in.
handle. Each.........................

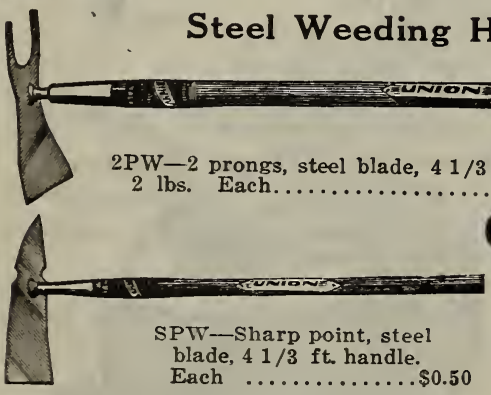

Planters Eye Hoe

SEOOO-Dutch or Potato Hoe. 6-inch half polished blade, Scovil field pattern. Fine for crushing lumps. Weight, 3

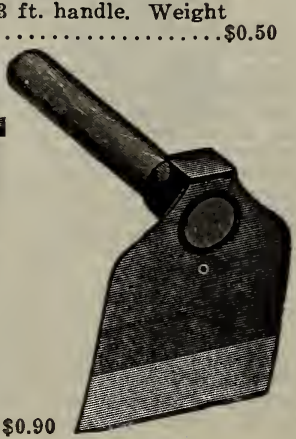

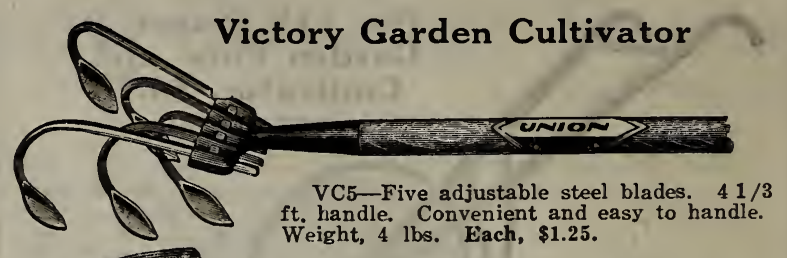

\section{Garden Dibbers}

For Transplanting Plants and Bulb

No. 218-Wood handle, hardened steel point. Weight, 1 lb. Each 50c, postage extra.

No. 220-All iron, hardened steel point. Weight, $1 \mathrm{lb}$. Each, 50c, postage extra.

\section{Asparagus Knife}

Tool steel, hand made.

Good for digging dandelions

as well as cutting asparagus.

Each, 35c; postpaid, $45 c$.

\section{Weeders}

THE IDEAL WEEDER

is one of the best weed. ers ever used in a garden. grade steel and will last a lifetime. Each, 25c; postpaid, 30c.

\section{HANDIEST
LANG'S
TOOL}

Popular, labor-saving, low priced cultivating de

vices. Style A. Three galvanized tines. Width, 2 inches; length, $91 / 4$ inches. Four Style (Illustrated). Width, 3 inches; adjust-

Width, 3 inches; adjust
able: length, 10 inches.

$40 \mathrm{c}$ esch or $50 \mathrm{c}$, post. paid.

Style G. Four galvanized tines. Width, 5 inches; adjustable; length, 57 inches. $\$ 1.00$ each, by express, not prepaid.

\section{Spading Forks}

\section{Handles}

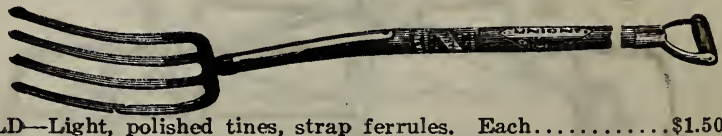

SALD-Light, polished tines, strap ferrules. Fach.......... TAHD-Heavy, polished tines, strap ferrules. Each............

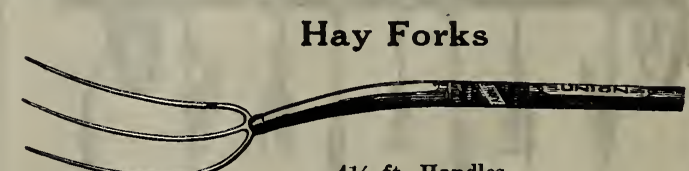

AS1341/2-Four 13-inch tines, strap ferrules. A good alfalfa fork. Each, $\$ 1.75$.

KS154 $1 / 2$-Four 15-inch tines, deep dish, strap ferrules. Kansas header fork. Each, $\$ 2.00$.

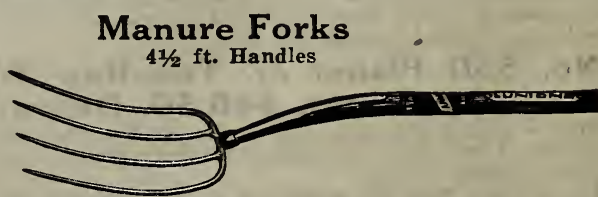

S441/-Four polished tines, strap ferrules. Each...........\$1.65 S541,-Five polished tines, strap ferrules. Each................. $\mathrm{S} 641 / 2$-Six polished tines, strap ferrules. Each.............. 2.00 Irrigating Shovels 


\section{Pruning Shears}

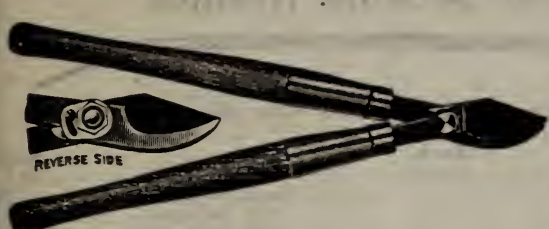

No $2030-30$-in handle, both sides drop forged from $s$ pecial alloy steel, polished and tempered; reinforced ferrules, polished: natural fipish. Hardwood handles; lock nut. Each, \$2.85, not postpaid.

No 4663 -Crucible steel blades, polished and tempered; double flat brass springs : ratchet, lock nut. Polished malleable iron handles. Weight, each, $11 / 4 \mathrm{lbs}$. Length, $91 / 2$ inches. Each, \$2.50, not prepaid.

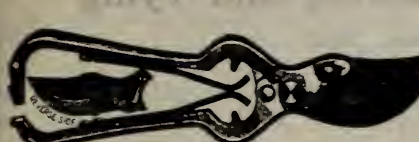
No. 466 -9 inch, prol quite so smooth a finish. Each, $\$ 2.25$, not prepaid.

No. $4667-9$ inch black same as above. Finished in salack-a mighty good shear. Each, \$2.25, not prepaid.

No. $101 \mathrm{~T}-8$ inch Western Hedge Shears. Straight forged steel blades; notched. Each, \$2.50, not prepaid.

No. 101T-9-inch Blades. Each, \$2.75, not prepaid.

\section{Lettuce Trimming Knife}

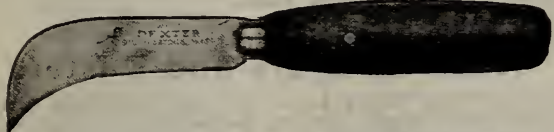

This is the style of knife used in the big lettuce loading sheds for trimming Head Lettuce. Made of high carbon polished steel. It is light, strong, and durable. Each, 50c.

\section{Garden Trowels}

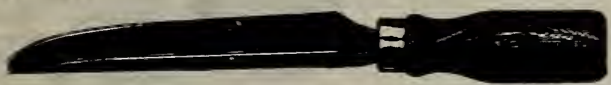

TRANSPLANTING TROWELS. The blade and shank of this trowel are made of one piece of heavy sheet steel, the shank being straight with the blade. It can be used as a trowel and dibble. Each, 25 ; postpaid, 35c.

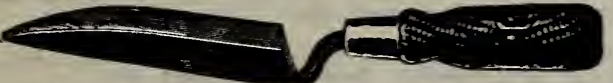

GARDEN TROWELS. English pattern, extra heavy, shanks riveted on blade by new method. An extra fine tool for setting plants and flowers. Each, 30c; postpaid, 35e.

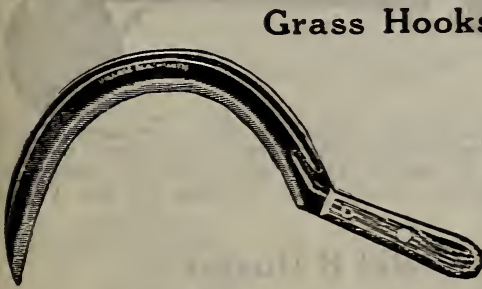

No. 4-Grass Hook, cutlery steel; corrugated, tempered blade; ground wide, thin and sharp. not postpaid, each, 60c.

No. 33-Grass Hook, with patented offset, swings perfectly in the hand with little muscular effort. Forged cutlery steel, tem pered, forged wide, ground with a long bevel, sharp, and whetted. Price, not postpaid, each, $\$ 1.00$.

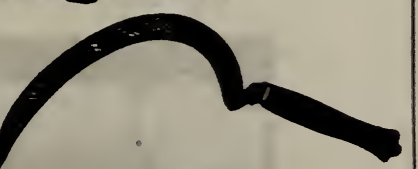

\section{Grass Shears}

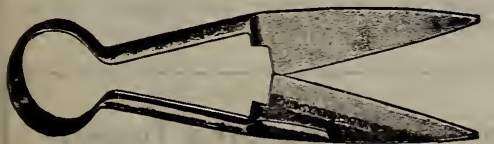

Grass Shears ; $5 \frac{1}{2}$ inch blade. Each, 75 , not postpaid.

Galvanized Watering Pots

Or sprinkling cans. Very convenient for hotbed use.

No. $616-6$ quart. Each, not postpaid...................\$ $\$ 0.85$

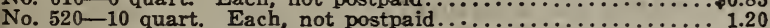

No. $526-16$ quart Each, not postpaid......................... 1.70

\section{Cyclone Seed Sower}

The Cyclone Sower is guaranteed to distribute seed perfectly, and will not throw seed in an and will not throw seed in an operator, but direct and evenly to the land. Sows clover, tim. othy, red top, alfalfa, osts, rye wheat, millet, buckwheat, turnip and other varieties of farm seeds. Clover seed is sown at a width of 18 feet: timothy, 15 feet: alfalf 8,20 feet :- wheat, 25 feet millet, 18 feet: oats, 18 feet.

Price, \$2.50 each, postpaid. $\$ 2.25$ each, not postpaid.
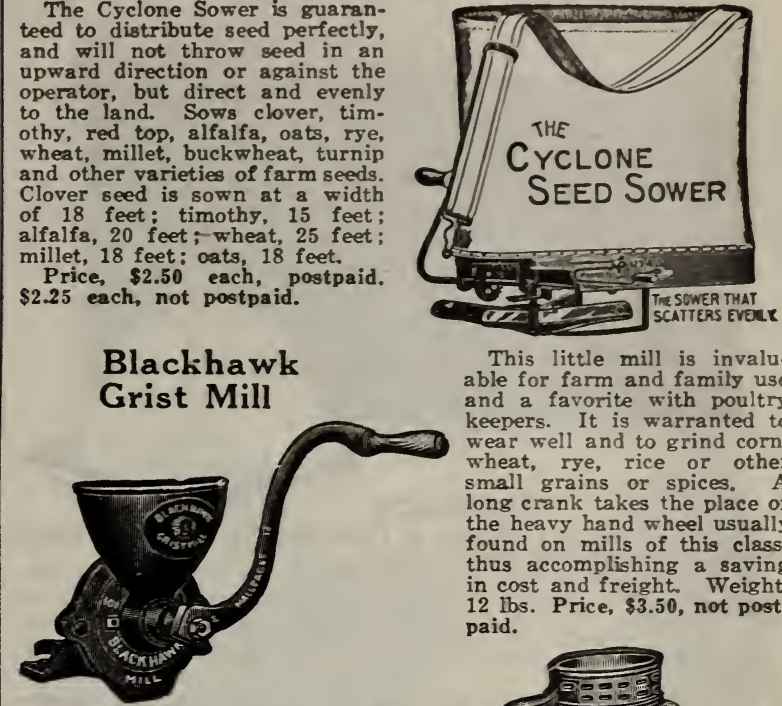

This little mill is invaluable for farm and family use and a favorite with poultry keepers. It is warranted to wear well and to grind corn, wheat, rye, rice or other small grains or spices, A long crank takes the place of the heavy hand wheel usually found on mills of this class. thus occompls thus accomplishing a saving in cost and freight. Weight, 12. paid.

\section{Blackhawk Corn Sheller}

This is a substantially made tool, easy to run; a boy can shell a large quantity a day with this machine. We have never known one to get out of order-will last a lifetime. Mailing weight, 12 lbs. Price, $\$ 3.25$ each, not postpaid.

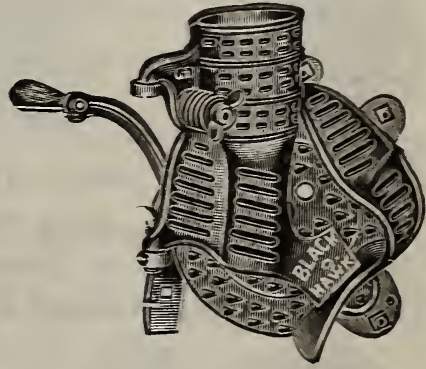

\section{Husking Tools}

Not Postpgid Unless Included with Snfficient Other Goods No. 200-Husking Peg. 16 gauge steel, heavy leather strap and lining. Each, 15c.

No. 202-Husking Peg. Like No. 200 but with large leather guard to protect first finger. Each, 20c.
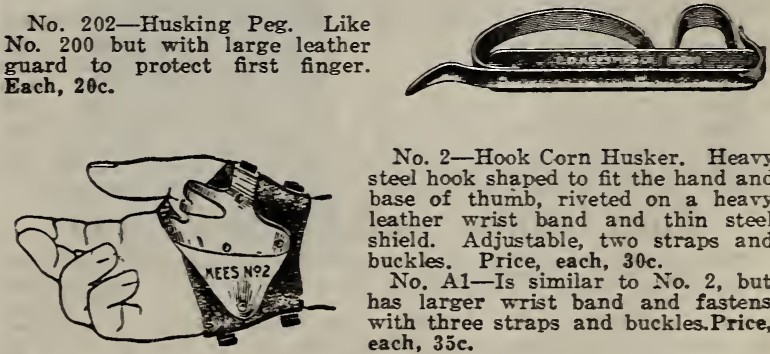

No. 2-Hook Corn Husker. Heary steel hook shaped to fit the hand and base of thumb, riveted on a heary leather wrist band and thin steel shield. Adjustable, two straps and buckles. Price, each, 30c.

No. A1-Is similar to No. 2 , but has larger wrist band and fastens with three straps and buckles.Price, each, $35 \mathrm{c}$.

No. 10G-Adjustable Corn Husk er. Two hooks that may be adjusted to different positions. The palm is lined with soft leather. Fastens with three buckles. Price, each, $45 \mathrm{c}$

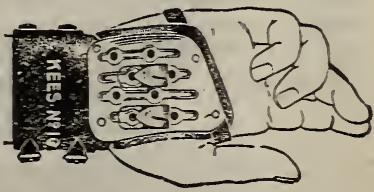

\section{Traps}

Catch the mice and rats and prevent loss.

Victor Mouse Traps. Three for 10c.

Victor Rat Traps. Each, 20c.

Not prepaid unless included with other goods.

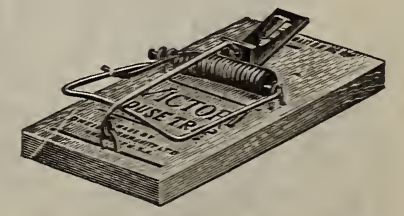


Higher Prices for Your Crops

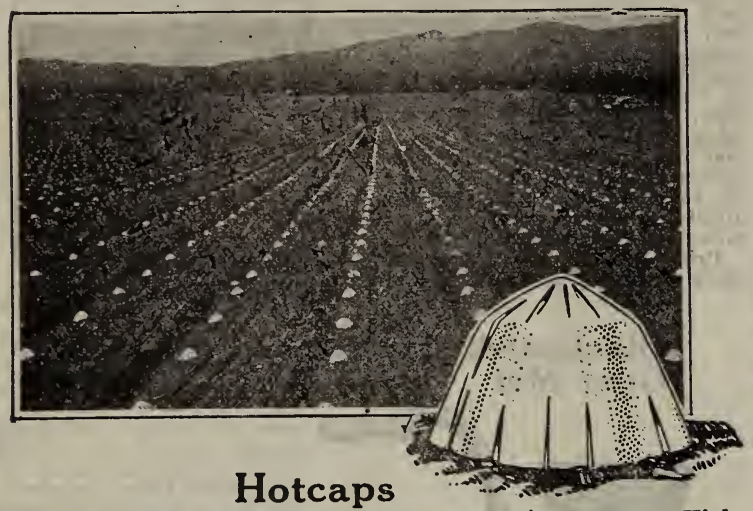

This Amazing New Method of Plant Protection gets you Higher Prices for Larger and Quicker Crops.

Last year thousands of growers added to the value of their vine crops by using Germaco HOTKAPS-shown above. This remarkable invention consists of a scientifically constructed wax paper able inention consiser houses that protect plants from frost, wind, rain, insects and ground

rusting. and faster. Thus you get a greater crop production to market earlier for higher prices!

One man can "set" 3000 Hotkaps per day. They not only bring you higher prices, but are a method of crop insurance-against th danger of the elements.

Prices per roll (1000 Hotkaps), $\$ 11.50 ; 100, \$ 1.50 ;$ doz., 30c.

\section{Hotcap Setter}

HOTKAP PLANT SETTER. Each, \$2.50.

\section{Transplanting Plant Bands}

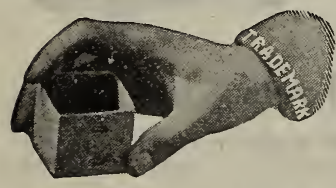

The simplest way to handle plants for transplanting is to grow them in our Ready-to-use Plant Bands, because they are ready to use and no time is lost in setting them up. You will find these bands very economical; they make an ideal worm guard. When transplanting the old way the roots are exposed to air and with the result that the plants are seriously set back. With Plant Bands it is even possible to transplant corn and cucumbers. Plants started in these possible to transplant corn and cucumbers. Plants started in

bands and set in the field never know they have been moved. Prices on these bands with folding bottoms; prepaid if included

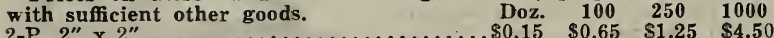

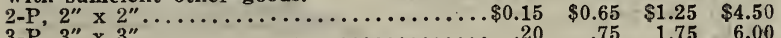

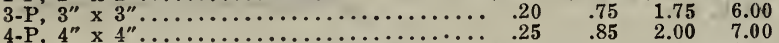
Order these with your seeds. Start the seeds early indoors in flats or boxes, transplant single plants into these bands and when the weather is settled set the plant in the garden without removing the band. Growth is not retarded and the plant is further advanced.

\section{Auto Display and Feeding Coop}

This new coop is of the same durable construction as the shipping coop shown below. It is made of the best galvanized wire permanently welded at each joint. There are two sections with roomy doors opening to each. The floors are strong and easily removed for cleaning. It is the most sanitary coop on the market. It is 41 inches high and 13 inches wide, weighs $19 \mathrm{lbs}$, and can be easily attach o sightly, unsanitary makeshift coop that protrudes beyond the car and is a menace to traffic. It is also excellent for display and feeding purposces, or when not on the auto for general use about the poultry yard. Price, not prepaid, $\$ 3.00$ each.

\section{Wire Shipping Coop}

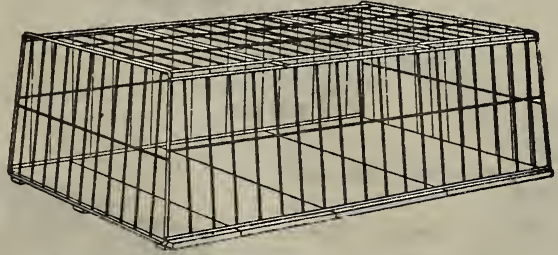

This shipping coop is, as illustrated, strongly built of galvanized wire and is electrically welded at each joint. It is 41 inches long, 13 inches high and 27 inches wide. The floor is easily removed. The door in the top can be securely fastened, very quickly. Every poultry shipper should have one.

Price, not postpaid, $\$ 3.00$ each.

\section{Steel Sacking. Needles}

Not postpaid unless included with other goods.

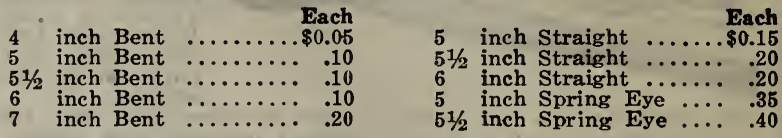

\section{Twine for Sacking and Tying}

$21 / 2$ oz. balls, 4 ply White Cotton. Each................. $\$ 0.10$ $1 / 2$-lb. balls, 4 ply Jute. Each........................ .20

4 ply Jute in Skeins. Per lb. $\ldots \ldots \ldots \ldots \ldots \ldots \ldots \ldots \ldots \ldots, .45$

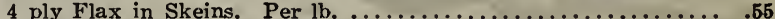

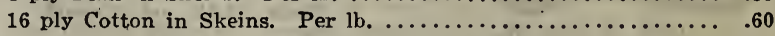

Not postpaid unless included with sufficient other goods.

Jute Twine for tying Celery and Bunch Vegetables, in 1/2-lb., 3-lb., and 5-lb. Balls. 30c per lb.

Celery Tape-No. 17, Fast Blue and Red, for tying Celery for market, 1000-yd. spools. Each, \$3.25.

\section{Hand Sprayers and Dusters}

The hand sprayers shown below are very useful in small gardens, for spraying house plants, poultry houses, etc., and applying liquids in a fine mist with no waste.

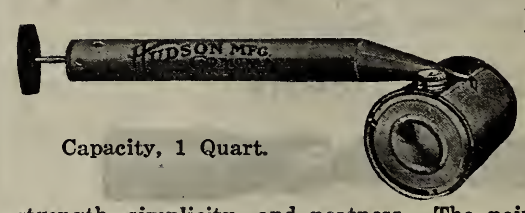

Misty Sprayer A universal favorite with the largest sale to its credit of any similar type sprayer. Note its and construction by which we combine strength, simplicity, and neatness. The point of the pump passes through the tank and is firmly soldered. Spray tube is aligned before soldering so that the air and syphon tubes are always in line. Every sprayer carefully tested and inspected before packing. These sprayers are specially built for us with a strong galvanized tank, the edges of which are painted. Weight, $1 \frac{1}{2} \mathrm{lbs}$. Price, not post paid, 75c. Same with tin tank, 55c.

MIDGET SPRAYER. Same construction as the Misty, but only a tin tank. 1 pint capacity. Each, not postpaid, 35c.

\section{Continuous Hand Sprayer}

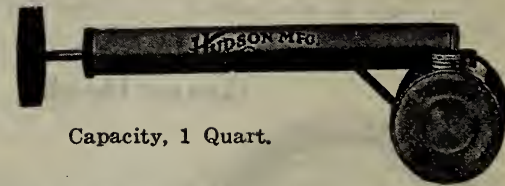

This is the best hand sprayer made. It has a compressed air chamber which makes the pressure continuous, has brass nozzle adjustable to spray fine or coarse; brass ball valve; is simple in construction, light and durable; works easy. Weight, $11 / 2 \mathrm{lbs}$. Price, each, not prepaid, $\$ 1.00$.

\section{Feeney Model B Duster}

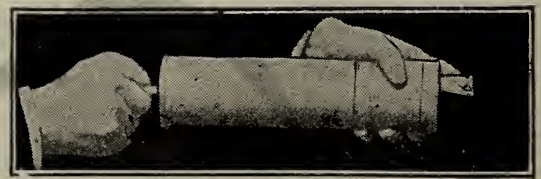

For gardens, flowers, etc., used also for killing flies, roaches, mosquitoes, etc. Perfect regulation-only duster that actually shoots Price, $\$ 1.00$ each. Postpaid, $\$ 1.25$.

For Information Regarding Insecticides see page 86. A large, complete spraying guide chart will be mailed on request. 


\section{GOLD \\ Buy and Plant \\ Spray Pumps}

\section{Compressed Air Sprayer}

This is a high pressure compressed air sprayer for any and all work. It is particularly adapted for spraying potatoes and garden truck, fruit trees, and rines, shade trees and ornamental shrubs, for whitewash, cold-water paints, disinfectants, de-odorizers, insecticides, Whitewash, cold-water pain

stock dips, foor oils, etc. All reams are riveted and soldered. Pump is of seamless brass tub ing which seals into the tank by a simple twisting device controlled by a turn of the $D$ handle. It is easily removed for filling, clean ing, etc. Hose is special spray hose for high pressure. Equipped with automatic shut-off nozzle, and can be used with an extension if desired.

Capacity, about 4 gallons. Shipping weight, 11 pounds.

No. 110G-Galvanized tank. Price, each, \$6.50.

No. 110-B. Brass tank. Price, each, $\$ 9.00$.

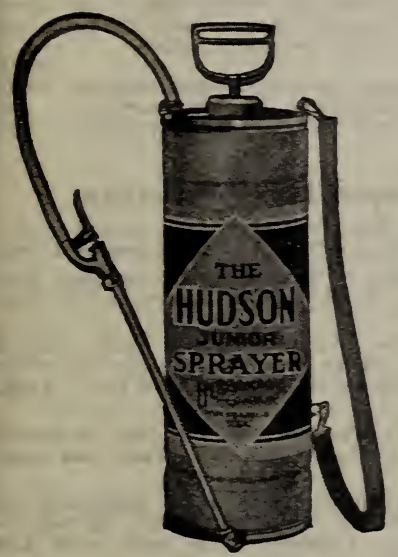

\section{Compressed Air Junior Sprayer}

This sprayer has the same construction as the larger one, but it is designed for those who have only a small amount of spraying and who desire a lighter load.

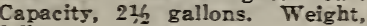
8 lbs.

No. $140 \mathrm{G}-\mathrm{Ga}$ lvanized tank. Each, $\$ 5.00$.

No. 140B-Brass tank. Each, $\$ 5.00$.

\section{Little Giant Sprayer}

These spray pumps are constructed entirely of brass They are so arranged that the labor of pumping is all done on the downward stroke of the piston and nothing on the up. The effect of this operation while pumping is to bold the pump down. The foot rest steadies the pump, holding it in proper position. They are provided with large air chambers, and have brass ball valves and detachable hose; the nozzle throws a continuous spray, and is not affected by the movement of the plunger. Will carry a pressure on the nozzle of from 50 to 100 lbs. with very ordinary exertion. Will throw a stream fifty feet, and are of unusual value for spraying trees, washing. windows and buggies, extinguishing fires, sprinkling lawns, flowers. Weight, 6 lbs. Price, $\$ 4.25$ each, not postpaid.

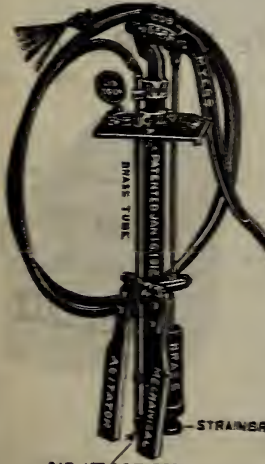

\section{Cog Gear}

\section{Barrel Spray Pump}

The construction is such that the entire pump sets inside the barrel containing the liquid, being bolted fast at its upper end to the head of the barrel. By this arrangethe head of the barrel. By this arrangemreged in the liquid that is to be sprayed. thereby avoiding all possibilities of losing priming, doing away with the necessity of a suction pipe, placing the agitator in the bottom of the liquid in a simple form, and also doing away with a large amount of complicated parts. Base fits $8 \times 8$ inch hole.

DAT JEKETAT OR feet boge 40 lbs. Price, co

No. 604 Crank Driven Duster

No. 604-Crank Driven Powder Duster can be used with one or two nozzles. Will handle any powder to an accurate gauge. Growers with extensive acreage will find this a very efficient machine. Weight, 22 lbṣ. Price, $\$ 15,00$.

\section{Paragon Sprayers}

This is the only machine on the market that works satisfactoril for several purposes. It is positively a first-class white-washing machine, as well as tree spraying machine. The spray nozzle cannot clog, no matter how dirty the liquid, as the liquid passes through the automatic self-strainer before entering the pump. A heavy, steady pressure is easily obtained. This is a very well constructed and a lasting and durable machine. A guarantee is furnished with every one.

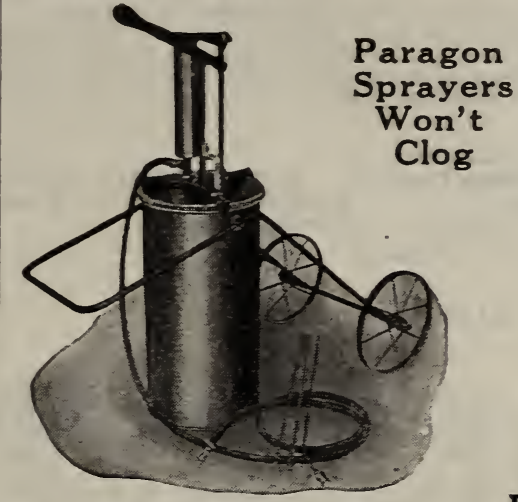

Paragon No. 3

Twelve-gallon. Equipment, $i \frac{1 / 2}{2}$ feet extension pipe, 10 feet 6-ply hose, 2
spraying nozzles. This machine is mounted on a strong steel frame, and can easily be wheeled to any desired place. Price, $\$ 25.00$.

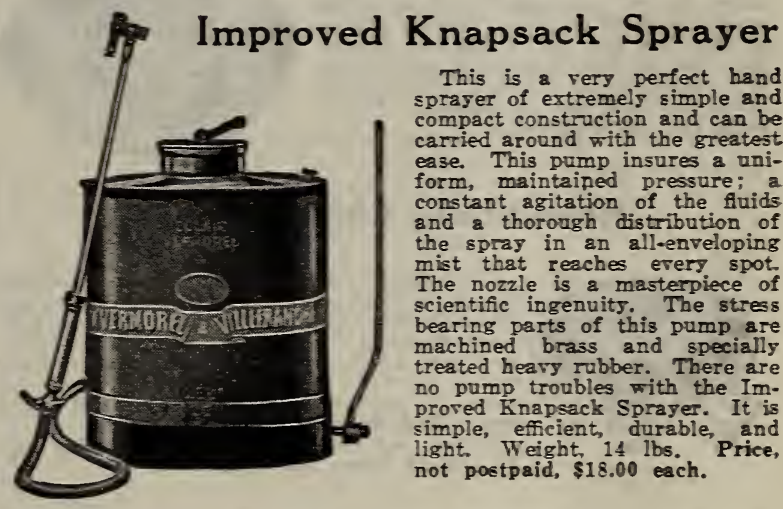

\section{Improved Knapsack Duster}

This Powder Duster is an efficient companion for the Improved Knapsack Sprayor. This type is commonly called a "puffer" as the flow is intermittent, not constant, but for general use it is the most serviceable. It will dust Sulphur, Arsenate of Lead, Paris Green, Bordeaux Powder, Lime, Tobacco or Nicotine Dust. It is light, weighing only 11 lbs. (shipping weight, 17 lbs.), and is carried on the back, as a knapsack, with ease. A light stroke of the lever insures an even flow of material with sufficient force for thorough penetration. Equipped with fine and coarse screens and ad. justing slide to regulate volume of fow. The Improved Knapsack Dustter is of the bellows type, and has no cogs, wheels, belts or other complicated mechanism that would be likely to wear and give trouble. Price, not postpaid, $\$ 15.00$ each.

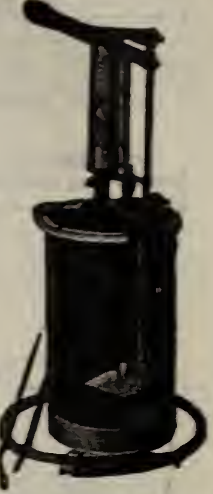

Paragon No. 1

Five feet 6-ply hose, feet spray hose, 2 nozzles. This cut of No. I Spraye shows inside mechanical arrangement and patented self-cleaning strainer. No other sprayer can show this feature. Price, 17.50 .

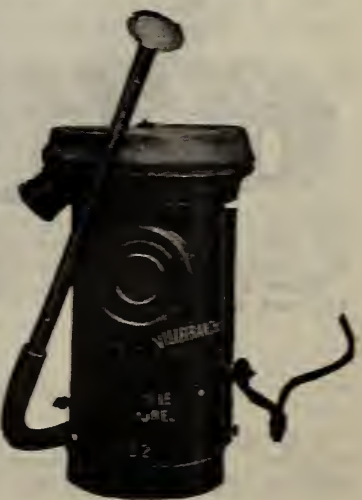


Armstrong Standard Spray Pump

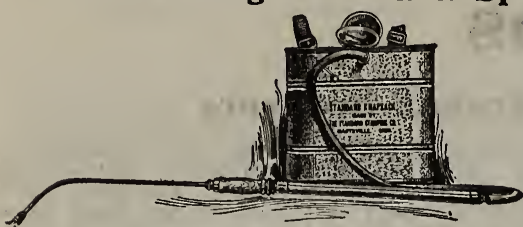

PUMP AND KNATPSACK, $\$ 8.50$. Weight, 12 lbs. is ideal for sprayin is ideal for sprayin

The Armstrong Standard Spray pump liquid insecticides of all kinds, for whitewashing poultry houses and cattle barns, for spraying ings or on animals and poultry, for fire protection, for veter-

inary use, for washing autos-there is almost a daily use for th Armstrong Standard about the home, farm, garden, and orchard.

The Armstrong Standard is made entirely of brass. No leather packings are used and no metal subject to rust or decay. Every Armstrong Standard Pump is warranted for five years. This makes it the most economical spraying device on the market.

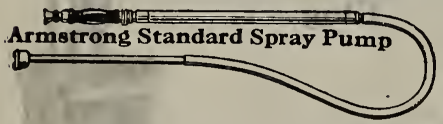

PUMP WITHOUT KNAP SACK. We

\section{Star Fountain}

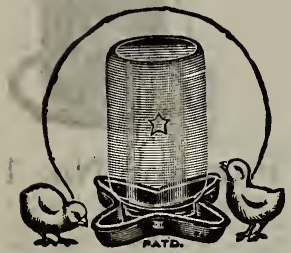

The Star Fountain is made of a single piece of heavy non-rusting metal without seams, solder or loose parts. It cannot leak, Little chicks cannot drown. It can be used for feed as well as water. Made in one size only which will fit any Mason jar. We do not furnish the jars. Price, each, 10c, not postpaid.

\section{Round Jar Fountain}

The Round Jar Fountain is made in extra heavy galvanized iron or blue enamel without the use of solder. There is only one size but it fits any Mason Jar. We do not furnish the jars. Thi is a very sanitary fountain. It is well made and will last indefinitely. Price, each, 10c, not postpaid.

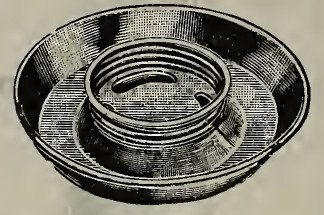

\section{Round Baby Chick Feeders}

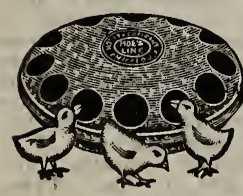

These feeders are very popular as the chicks cannot upset them and they keep the feed clean and sanitary. The top fits snugly but can be easily removed for cleaning and filling. They are well made from the best quality tight coated galvanized iron and can be used for water or milk as well as mashes and grain feed. Made in two sizes. Prices, not postpaid: No. 11, 8 holes, $15 \mathrm{c}$; No. 12, 12 holes, 25c each.

\section{Royal Feed Troughs}

This is a fine popular priced feeding trough made of galvanized iron and intended for chicks and growing stock. The pan and top

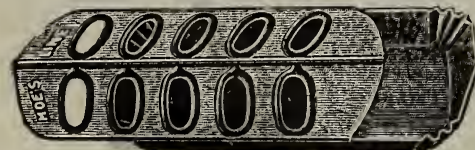
are both stamped in one piece, no seams, rivets or solder used. The sliding top makes them easy to fill and keep clean. Made in two sizes. Prices, not
postpaid.

No. $312-12$ inches long, 16 holes. Each.............\$0.25 No. $318-18$ inches long, 26 holes. Each.................. 40

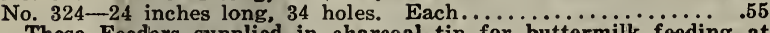
These Feeders supplied in charcoal tin for buttermilk feeding at $10 \mathrm{c}$ each higher.

\section{Little Putnam Stove}

Uses three tablespoonfuls of oil a day and burns a month without attention. Keeps poultry fountains unfrozen in zero weather. A neat unit for oat sprouters. Price, $\$ 1.95$.

\section{Royal Bottom Fill Fountains}

This popular, low-priced water fountain is made in two pieces, accurately stamped and formed from the best quality galvan ized iron, in three sizes. It is easily filled and easily cleaned. The round taper shaped top prevents bursting from freezing and keeps the fowls from roosting on it.

No. 25-1 qt., 6 in. high. Each......\$0.30 No. 50-2 qts., 8 in. high. Each...... .45 No. $75-1$ gal., $91 / 2$ in. high. Each....
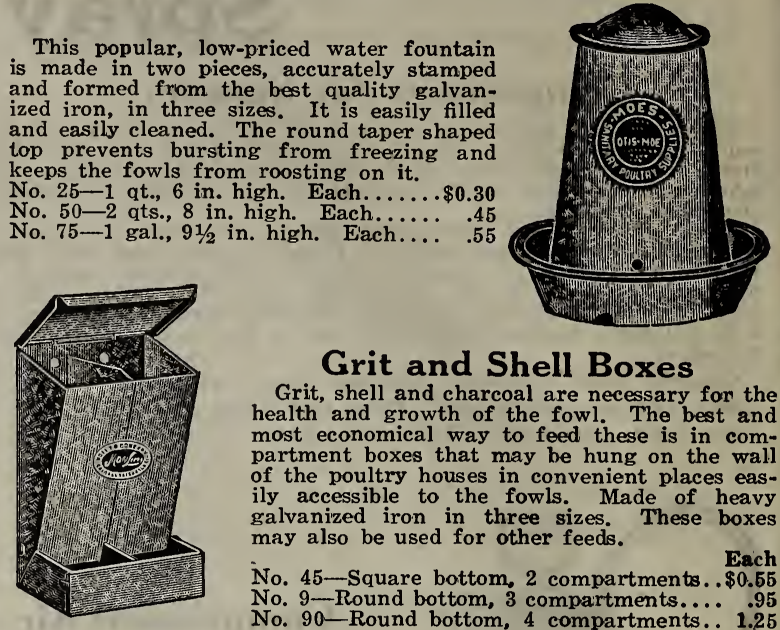

\section{Grit and Shell Boxes}

Grit, shell and charcoal are necessary for the health and growth of the fowl. The best and most economical way to feed these is in compartment boxes that may be hung on the wall of the poultry houses in convenient places easily accessible to the fowls. Made of heavy galvanized iron in three sizes. These boxes may also be used for other feeds.

No. 45-Square bottom, 2 compartments. $\$ 0.55$

No. 9 -Rquare bottom, 2 compartments..\$0.55 No. 90 -Round bottom, 4 compartments... 1.25

\section{Thermometers and Hygrometers}

No. 5774-Tycos, angle pattern, flange on upper edge turned over to hook on wire or metal strip, four inch scale. Each, postpaid. 90c.

No 5770-Tycos, straight pattern with adjustable brass legs, four inch black oxidized brass scale with white filled figures and graduation. Each, postpaid, $\$ 1.00$.

No. 5782-Tycos Certified, angle pattern, four inch black oxidized brass scale; every fifth line and figure stamped on scale and white filled and every single degree encraved on mercury filled tube. Each, with certificate, postpaid, $\$ 1.50$.

No. 5981-Tycos Soil (Hotbed) Thermometer. 15-inch V-shaped wood case with handle, strong pointed metal end. Each, not postpaid, $\$ 2.75$.

No. 5796-Tycos Incubator Hygrometer, $33 / 4$ inches high and $41 / 2$ inches wide over all. Prevents loss of millions of chicks by indicat ing the percentage of moisture. Complete with bowl, wick and thermometer, each, postpaid, $\$ 2.00$.

\section{Glass Nest Eggs}

These are a very close imitation of a real egg, both in shape and color. They are durable and not easily broken. Each, 5c; per doz. $40 \mathrm{c}$, not postpaid.

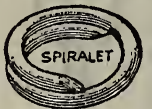

\section{Spiralet Celluloid Leg Bands}

Ten showy colors permit different flocks to be readily identified. Very light and durable.

No. 5 - Pireon $12 \quad 25$

No. 4 -Day old Chick $\ldots \ldots \ldots \ldots \ldots . .10$

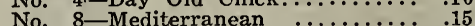

No. 8-Mediterranean $\ldots \ldots \ldots \ldots \ldots \ldots \ldots \ldots \ldots . .15$

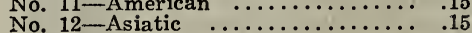

No. 12-Asiatic

$\begin{array}{rrrrr}25 & 50 & 100 & 1000 \\ \$ 0.20 & \$ 0.35 & \$ 0.60 & \$ 4.00 \\ .20 & .35 & .60 & 4.00 \\ .25 & .40 & .70 & 6.00 \\ .25 & .40 & .70 & 6.00 \\ .30 & .55 & 1.00 & 8.75 \\ .30 & .55 & 1.00 & 9.75\end{array}$

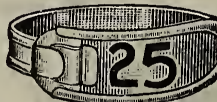

Adjustable Leg Bands

Made of pliable aluminum. 12 for 15e; 25 for $25 \mathrm{c} ; 100$ for $75 \mathrm{c}$.

\section{Farmer's Friend Egg Carrier}

This is a strongly built, light weight Egg Carrier, that holds 12 dozen eggs. But the patent adjustable cover makes it possible to carry one dozen just as safely as 12. The farmer and poultry man will find it very serviceable. Weight, 8 lbs. Price, not postpaid, each, $\$ 1.25$; six dozen size, each, $\$ 1.00$.

\section{Egg Cartons}

These are convenient for marketing eggs by the dozen. We have them in two styles, oblong, 3 eggs by 4 eggs; and long, 2 eggs by 6 eggs.

They are one thickness of pasteboard with light weight fillers. Both are one dozen egg size. 


\section{Stock and Poultry Feeds}

\section{Blatchford's}

Blatchford's Chick Mash

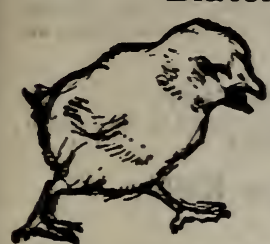

Blatchford's Chick Mash is the favored starting and growing feed of the most prominent poultry raisers in the country. chicks need right from the start. It shields them from white diarrhea bowel trouble and leg weakness.

This mash is

neither a tonic

nor a medicine, but a nutritious, atable body-builder. It promotes health, vitality and growth by building up sturdy. disease-resistant frames. It does not force, but by supplying proper nourishment to each and every part of the body, it promotes steady and complete develop ment in the shortest possible time.

Blatchford's Chick Mash contains no screenings, hulls or cheap by-products from the manufacture of breakfast foods, cereal foods or scratch grains. It carries chicks all the way-starts, grows and chicks all the way-starts, grows and Blatchford's Growing Mash may be sub stituted at the end of 4 or 6 weeks. $10-1 \mathrm{~b}$. bag, 75c; 25-lb. bag, $\$ 1.50$; 100-lb. bag. $\$ 5.50$, not prepaid.

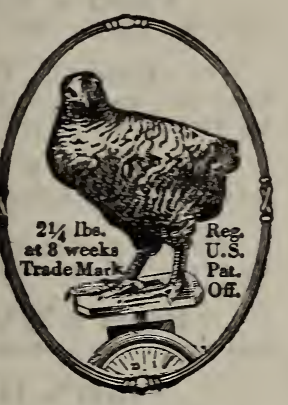

\section{Blatchford's Growing Mash}

Price, 25 lbs., $\$ 1.25 ; 100$ lbs., $\$ 4.00$.

\section{Blatchford's Calf Meal}

Blatchford's Calf Meal is the original Milk-Substitute. It was the first on the market. For over one-third of a century it has been successfully used in raising calves by the most progressive farmers and dairymen in this country. It is the only calf meal backed by so remarkable a record.

Its success is due to three things. FIRST, its quality. Blatchford's is above all a quality calf meal. Only the best materials are used ture. It contains no waste materials or $O N D$, it contains all the nutritive and
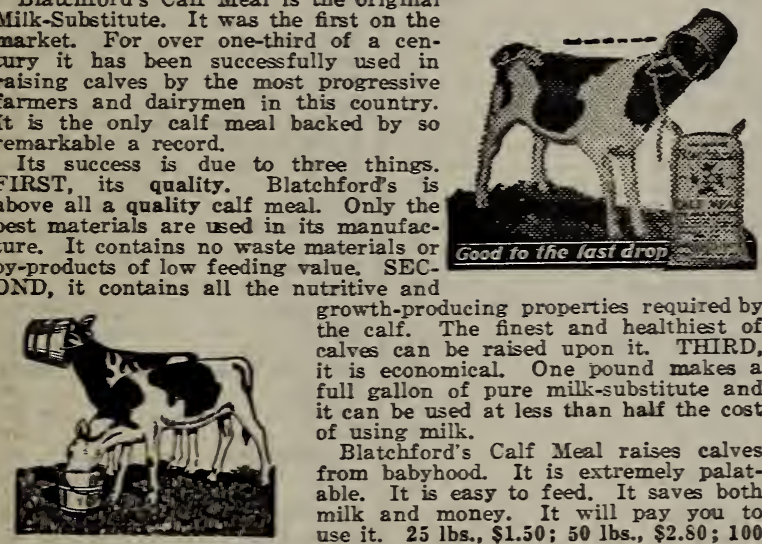

growth-producing properties required by the calf. The finest and healthiest of it is economical. One pound makes a full gallon of pure millk-substitute and it can be used at less than half the cost of using milk.

Blatchford's Calf Meal raises calves from babulatable. It is easy to feed. It saves both able. It is easy to feed. It saves both milk and money. It will pay you to
use it. $25 \mathrm{lbs.,} \$ 1.50 ; 50 \mathrm{lbs}$., $\$ 2.80 ; 100$ lbs., $\$ 5.50$, not prepaid.

\section{Blatchford's Egg Mash}

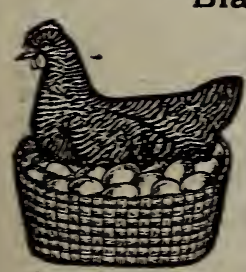

Blatchford's "Fill-the-Basket" Egg Mash is built upon the principle that eggs are manufactured from the feed the hen receives. In other words, the hen is an egg-making factory. Her feed is the raw material from which she makes her eggs. Consequently, her feed must be rich in materials required for egg-producbe rich in materials required for egg-producThey will maintain the hen's life, but surplus nourishment is absolutely necessary if she is nourishment is absolutely nece

Blatchford's Egg Mash contains a large variety of the best materipls available for egg TRADE.MARK lem of securing eggs both Winter and Summer. Feed it you will find it a profitable thing to do. Every bag guarante

Blatchford's Lamb Meal

Price, 25 lbs., $\$ 1.50$; 50 lbs., $\$ 2.80$.

\section{Blatchford's Pig Meal}

Price, 25 lbs., $\$ 1.50 ; 50$ lbs., $\$ 2.75$.

\section{Gold Seal Baby Chick Feed}

HOYT'S MIXTURE. A wholesome, ready prepared, starting feed hich will nourish the chicks so they can make rapid growth. Contains the necessary materials to form bone and feathers, such as seeds, millet, and grains. It gives the chicks quick growth and tends to keep them in good health. To properly develop the chick. tends to keep them in good health. To properly develop the chick, either for market or to become a producer of eggs it must be fed
such feed as will promote growth quickly and uniformly. 5 lbs., $25 \mathrm{c}$; 10 lbs., 50c; 25 lbs., $\$ 1.00 ; 100$ lbs., \$3.00. These prices are not prepaid.

\section{Crushed Oyster Shell}

Hens must have lime in some form to furnish egg shell material. If you are having trouble with your flock laying soft or thin shelled eggs and should start feeding Oyster Shell immediately to remedy this condition. Our shell is not ground from shell deposits but from less waste. 5 lbs., 20c; 25 lbs., 60c; 100 lbs., \$1.35, not prepaid.

\section{Crysco Lime Grit}

A clean, sharp grit containing elements both helpful and necessary for the proper nutrition of food and production of eggs. It is gray in color and contains no dirt, causing no waste. Please state whether 25 lbs., 40c; 100 lbs., $\$ 1.35$, not prepaid.

\section{Charcoal}

Charcoal is a conditioner and not a food. It absorbs impurities and carries them from the system. It may be mixed with scratch feed or fed in feeders. We have three sizes: Hen Size, Chick Size and Powdered. 3-lb. pkg., 25c; 50 lbs., \$2.00, not prepaid.

\section{Feeding Tankage}

Hors require animal feed ang the lack o kill chickens or eat their young. Tankage is a hog feed and produces marvelous results when mixed with other feeds. Protein, 50 per cent. Per 100 lbs., $\$ 4.00$. Write for prices on larger quantities.

\section{Meat Meal}

This is a variety of meat feed that is very popular. It is ground fine and can be included in mashes. We can furnish this feed practically free from odor. 5 lbs., $30 \mathrm{c}$; 10 lbs., $60 \mathrm{c} ; 25 \mathrm{lbs}$., $\$ 1.25$; 50 lbs.. $\$ 2.10 ; 100 \mathrm{lbs}$., $\$ 4.00$, not prepaid.

\section{Meat and Bone Scraps}

This is a high class meat product prepared from animal matter that has not decomposed. Contains 50 per cent protein and will compare favorably with the best products of this nature. $5 \mathrm{lbs}, 30 \mathrm{c}$ $10 \mathrm{lbs}$., $60 \mathrm{c} ; 25 \mathrm{lbs}$., $\$ 1.25$; $50 \mathrm{lbs}, \$ 2.10 ; 100 \mathrm{lbs}$., $\$ 4.00$, not prepaid.

Gold Seal Granulated Meat Scraps These are in granular form about the size of a field pea and are just the thing for scratch feeds. Prices, not prepaid: $5 \mathrm{lbs}, 35 \mathrm{c}$; 10 lbs., 60 c; 25 lbs., $\$ 1.40$; 50 lbs., $\$ 2.25$; 100 lbs., $\$ 4.25$.

\section{Blood Meal}

Blood Meal contains the highest per cent of protein of any known feed and is too rich to be fed heavily. It prevents diarrhoea and scouring. $5 \mathrm{lbs}, 50 \mathrm{c} ; 25$ lbs., $\$ 1.50$; 50 lbs., $\$ 2.75 ; 100$ lbs., $\$ 5.00$, not prepaid.

\section{Bird Food}

Canary, recleaned, imported.

Lb.

Dwarf Essex Rape, fancy recleaned

Memp, Manchurian,

Bird Millet.

Bird Sand.

Sunflower, recleaned, for Parrots

Cuttle Fish Bone, $5 \mathrm{c}$ to $10 \mathrm{c}$ each

Postpaid. Special prices on larger quantities.

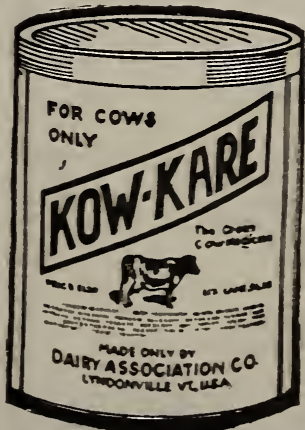

Kow-Kare

The Best and Cheapest Insurance on the Health of Your Cows

KOW-KARE has been used for a longer period of time and by a larger number of dairymen than any other remedy with which we are familiar. KARE is a trusted preparation. Not On $K O W-K A R E$ ps near to an inonly is KOW-KA can be, but it is without harmful effect. There is nothing in it but what is comforting and curative. Recommended for Scouring, Lost Appetite, Bunches, es pecially for possible or threatened Abortion, for Barrenness, for Retained Afterbirth and Milk Fever. Large size, $\$ 1.25$; medium size, $65 \mathrm{c}$; six large cans, \$6.25.

MORE MILK FROM THE COWS YOU HAVE. A valuable book, furnished free. 


\section{Stock and Poultry Remedies and Supplies}

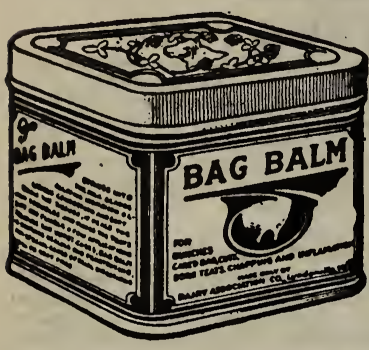

Bag Balm

For all diseases of udder and teats, such as caked bag, sore teats, bunches, chapping, cuts, or inflamed parts, you can use this remedy with perfect safety; positive results in every case. There is nothing better for keeping all the parts healthy and in the pink of condition-sanitary and clean. The use of BAG BALM will make decidedly easier milkers of your herd. It has a variety of uses. That it is effective and gives real results in even the most stubborn ailments is proved by scores of letters from those who have used it. Insist on Bag Balm manufactured by The Dairy Association. Price, 60c.

\section{Grange Garget Remedy}

Manufactured by The Dairy Association, for that serious disorder peculiar to cows, and which is a disease by itself. Grange Garget

More Milk From the Cows You Have

\section{A valuable book, furnished free.}

Whitaker's Dip and Disinfectant

Prices, not prepaid: Pint, $40 \mathrm{c}$; quart, $75 \mathrm{c}$; $1 / 2$ gallon, $\$ 1.10$. 1 gallon, \$1.75 each; 5-gallon cans, $\$ 1.50$ per gallon; 50-gallon drums, $\$ 1.25$ per gallon.

\section{Pyru}

Prices, not prepaid: Pint, 75c; quart, $\$ 1.25 ; 1 / 2$ gallon, $\$ 2.00$; 1 gallon, $\$ 3.50$ each; 5-gallon cans, $\$ 3.00$ per gallon.

Denver Fly Chaser

Prices, not prepaid: 1 gallon, $\$ 1.50$ each; 5 gallons, $\$ 1.35$ per gal.

\section{Water Glass Egg Preserver}

Water Glass is recommended by the Department of Agriculture of the United States as being a very simple, economical and safe method for the preservation of eggs. Preserve eggs when plentiful and be prepared for a scarcity when your hens take a rest.

Put the eggs in a crock or jar and mix the Water Glass with water that has been boiled, using 12 parts of water to 1 part Water Glass, and pour it over the eggs. Be sure to see that all eggs are covered with the mixture. Eggs if allowed to stay in this solution, $40 \mathrm{c}$; $1 / 2$ gal., $75 \mathrm{c}$; 1 gal., $\$ 1.25$, not postpaid.

\section{Pratt's Poultry Regulator}

25-oz. pkg., 30c; 4-lb. pkg., 60c; 9-lb. pkg., \$1.20; 12-lb. bag, \$1.50; $25-$ lb. bag, $\$ 3.00 ; 100-\mathrm{lb}$, bag, $\$ 10.00$, not postpaid.

\section{Pratt's Powdered Lice Killer}

$1 \mathrm{lb}$., 30c; $21 / 2 \mathrm{lbs}$., 60c, not postpaid.

Pratt's Poultry Regulator

Don't risk heavy loss that can be easily prevented. 1 pt., $45 \mathrm{c}$ 1 qt., $65 \mathrm{c}$; $1 / 2$ gal., $\$ 1.10 ; 1$ gal., $\$ 1.85$, not postpaid.

\section{Pratt's Special Compound}

Small pkg., 25c; medium pkg., 50c, not postpaid.

Pratt's Roup Tablets and Powder

Small pkg., $25 \mathrm{c}$; medium pkg., $50 \mathrm{c}$; large pkg., $\$ 1.00$, not postpaid.

\section{Pratt's White Diarrhea Tablets}

Small pkg., 25c; medium pkg., 50c, not postpaid.

\section{Pratt's Head Lice Ointment}

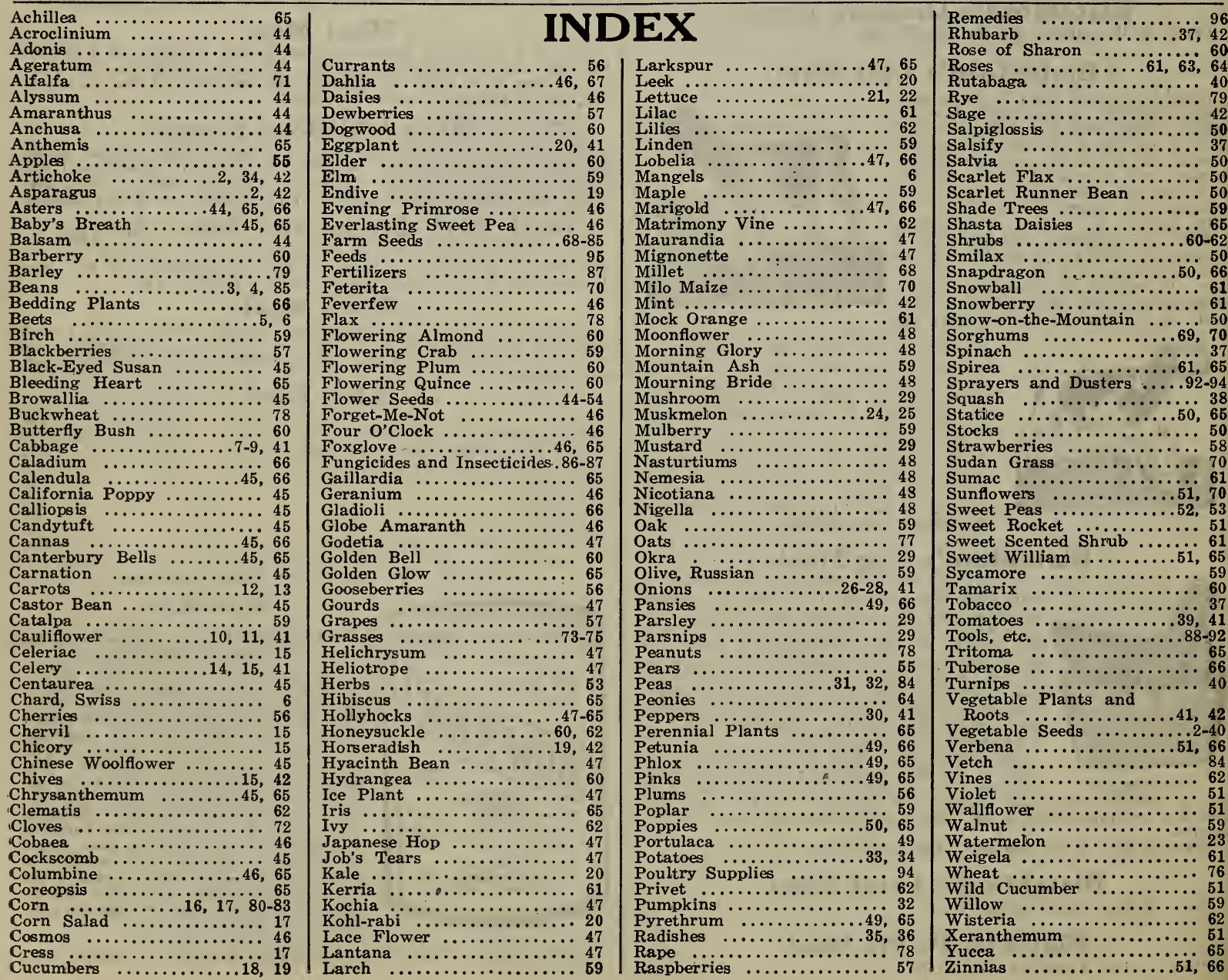




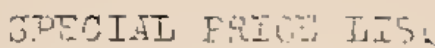

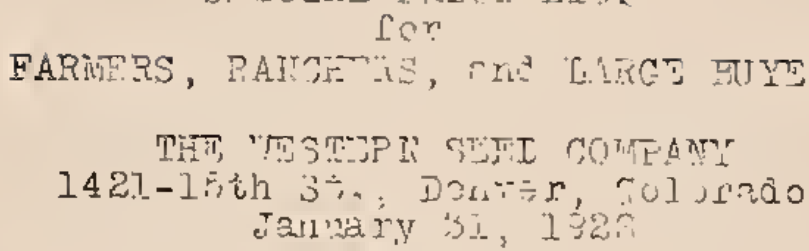

The prices fiven belo:. are those prevailine at date of

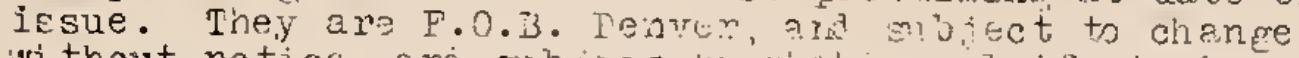
vi thout notice, and sub jes w w uharibl it stocks are

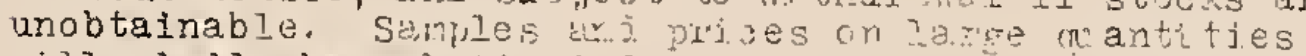
will gladly be subritted fo inspetion, umarison, and

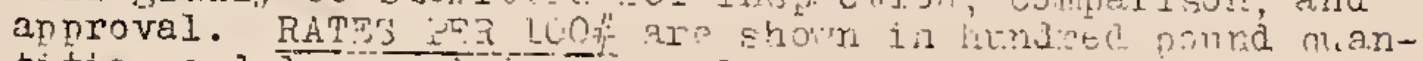

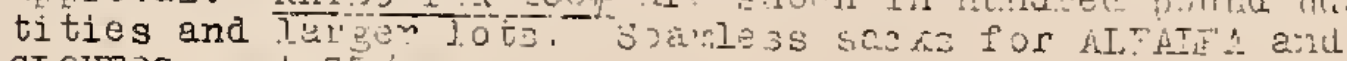
CLOYSiS cost żd eE.cn.

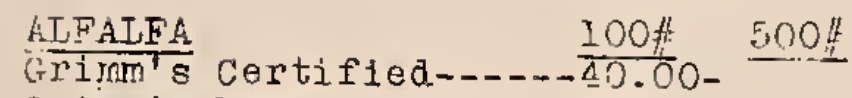
Grimm's Non-certified--32.

Turkestan, Domestic-..-25.v0-23.00

\section{CORMOI DOMESTIS ALFALTA}

Gold Seal Grade--.....23.00-22.75 No. 1 Grade-......-. $21.00-20: 1 / 5$ No. 2 Grade-.......... 19.001 .19 .75 INo. 3 Grade-............ $00-14.75$ No. 4 Graden........ 8.50-9.?E

\section{CLCVERS}

Alsyke, Tx. Fancy----- $33.50-32.25$ lreâium Red, Gold Seal-- $35.5 \Omega-35.00$ Mammoth Red, Fancy-n.-..53.5.0.33.00 "Thite for Lemins-...-- 42.50 (1-].b. 50,; 10-1b. 4.50$)$

=SWEET CICVER

Whi te jlosson, Hul] ed---12.00-11.50 Thite Blossor, Scarified-12.50-12.00 Yellow Elossorfi, Hulled--11.75-11.25 Fubam, frnual, white-n- $-25.50-24.50$ GRASSTS

Tis thy , Fancy-....... 8.00- 7.75 Western Iheat Grass---12.00-11. En Brome Grass-........-1.3.50-13.00

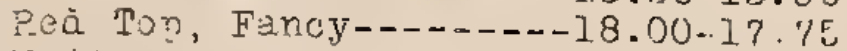
Native Rye Grass----1.5.00-14.2E meadow Fescue, Faricy-a-. $18.00-37.50$ Wrchard Griss, Fanoy--- $-2.1 .75-21 . .65$, Xy - Bl'xeGrass, Fency---- -30.00

$(1-1035 \phi ; 3-16$. 31.00$)$

GRASS IMTMT'RT

Tin. The dow Mirture---18.00-17.50 Mortons Pasture Mixture-18,00-17. A.l syke \& Timuthy lyixed--15,00-1.4.50 Mixed Lavm Grass--.---.-2ij, 00

$$
\text { (1-1b. 35 } 4: 3-1 b .43 .00)
$$

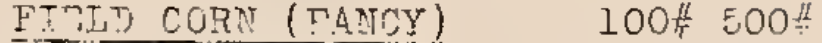

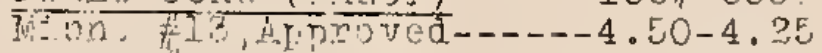
minn, tis Colo. Yello Dent------4.25-3.75

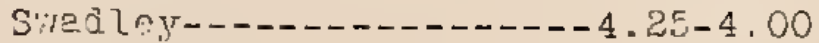
Golden Kinf-...-.....-. $1.50-4.26$ Reid's Ÿelioy Dent......

Pride of the Noriti-----4.75-4.50 iNcrthirestern Den White fusinalian.------4.i5-3.85

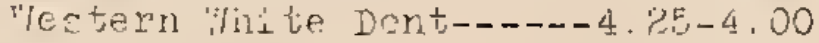
Gehiz-...-........--- E. OC-4.8E Hjokry Kinr-.......----

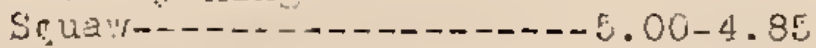

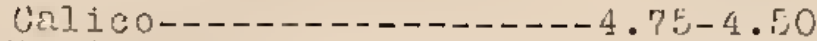
Western Yel a d Dunt--- -4.25-3.75

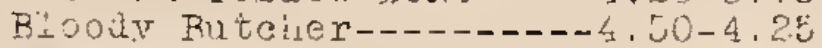

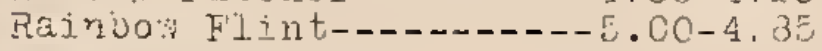

PTS ILAGE CORI

Iove Stivex lfine-----1.75.4.50

Rea Cob İisi, a

Colo. Ciant Foddex---- $-4.75-4.50$ Iona rold line-...---4.75-4.50

WHEAT

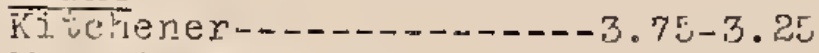

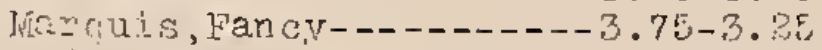
hetiance-....------4.00-3.75 reacaroni or Durum-..---

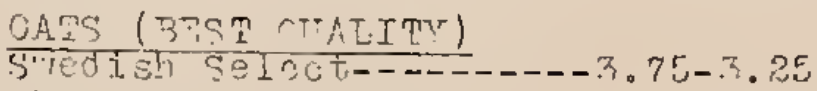
Kherson or pin.........

Silver wine-n.......

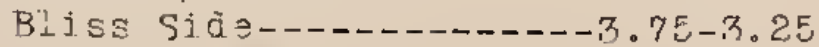
Viciory Genuine--.---- $3.75-3.25$ 

$\frac{\text { SORGHTMS, इTC. }}{\text { Gudan Grags- }}$ $100 \div 5004$

Tohns on Grass-....--15.00

3lack Amber Cane-------3. ". C-3.25 Ks. Oranec Sorgnum---- $-3.25-3.00$ Red Toy Cane-.....-.-4.00-3.75 Feteritz-........... Red Cane---.-- $-\cdots-3.75,-3.25$

IAFTIRS, पTC.

Schrock KEIfír, Ne:N----4.00-3.75 Kaffir, Dwarf White--m-3.50-3.00 Kaffir, Ret-----n-- $-3.75-3.50$ rilo liaize, Yellow-...-3.:30-3.0 Broom Corn---.-.-.-.-5. 25

\section{hIILETS}

Big ferman, True--.----4.25-4.00 Siberian or Russian---3.7t-3.50 wop or Nanitoba-------3.75-3.24 iThite ifonder-.-.-----4.00-3.75

\section{BARLTY}

BaId Or Full-less-----4.00-3.50 Hull-less Blue--.---.-

oderbrucker, Six Row----3.25-3:00 California Feed-- - - $-2.75-2.50$ Colsess---n--.---- $3.75-3.50$ Trebi-.....--n.-- $3.50-3 \cdot 25$

\section{RYE}

Surine, True stock-----3.50-3.25 Fall, Petkus variety----3.25-3.00

FIEIL PrAS

San luis Valley--------4.15-4 : 50 Ex Ea Blackeye, Dryland-8.2"

Th1 ppoorwill Co'v Feas--

Janada Field-...-.-- $5,25-5.00$

\section{RAPE}

D!rarf Essex, Imuorted---9.75-8.50 गुTCII

Sand or Hairy--..---15.00-1.4.75 FLAI

Testern Gro:m--..--- -

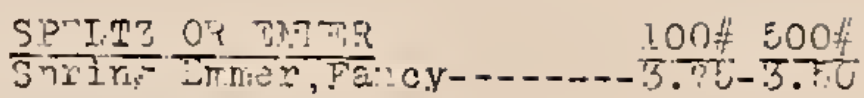

Buts

J

Silver Iull

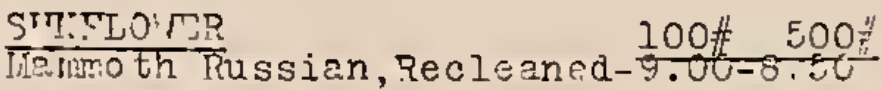
Bier Malchurian--..----74.00-13.5C

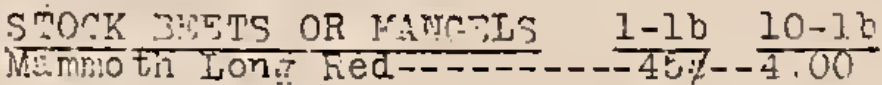
Siuds trup---.-.-...-.--45t--4.00

rient Helf Suger-a.-.---45 $\phi--4.00$

Golden Tankard-........

OPION ST,TS

Red Bottom-.-.-.--

Thite Bottom--...--.-.-4.00

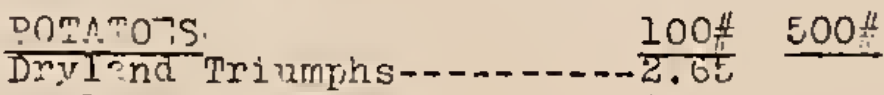
Divland 5obblers-------- -2.65

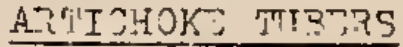

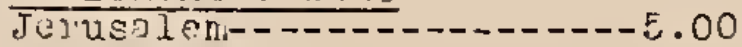

CONOTHSIP g, MIS

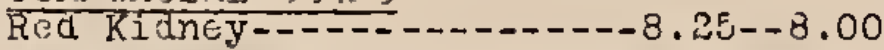

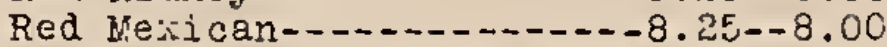

Broad Vindsor(Horse 3ezn) 22.00

Pinto or Kexican-----.--7.5il--7.00 Wh . Marro":fat, Gr Northern--

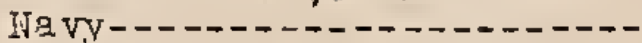

STOCK 3 TNS

Early soja or soy-...---10.2E

Ito Sarl So jas.-.......

Hollybrook warly sojas---10.7

POPCO:3N

Spanish Pon Corn--------

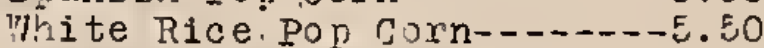
Jarianese Hull-1ess------- E. EO

$$
(1-10.10 \div 3-1 b .25 d)
$$

Cheap seeds are dear at any price. It alwys nays to buy wellcleaned, dependable seed such as can only be obtained from reliable sources pioperly equirped for such "ork.

Under supervision of r. S. Dert of Aericilture, :ve arc authorized to issue verified-origin seed certificates for Alfalfe, slovers, and seed corn, the locality of nroduction of which has been velified by a Federal seed inspector. 



\section{Porering}

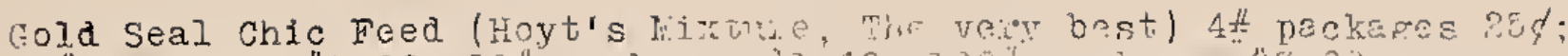
35\# packares

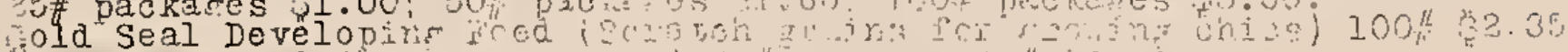

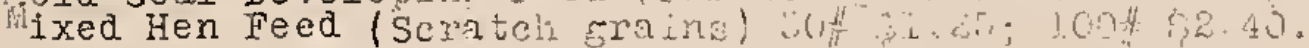

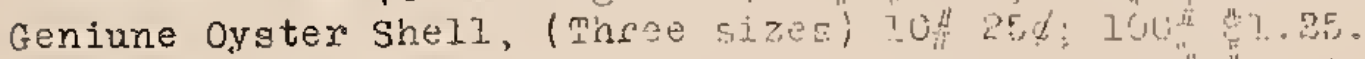

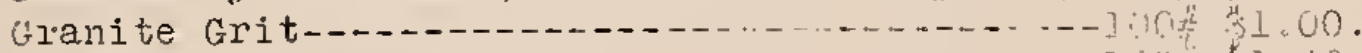

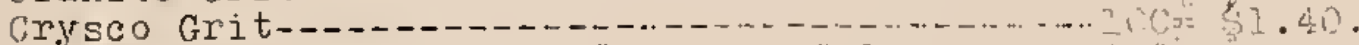

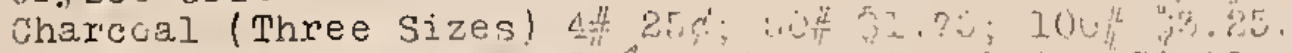

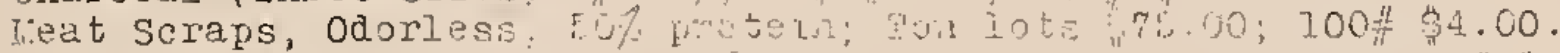

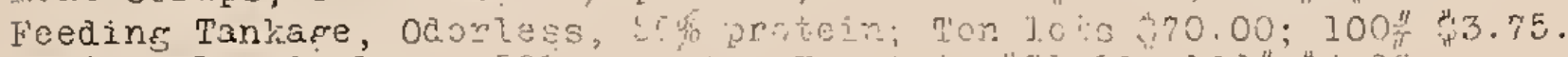

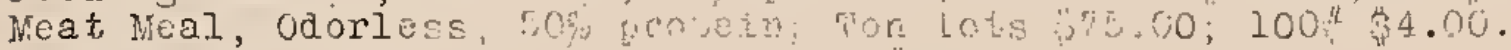

Ground oil Cake-..........................

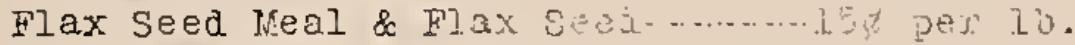

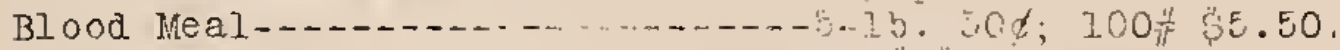

Kaffir Corn or Milc Waize.......

Millet-..............

Alfalfa Meal, xxx finc-.-...-100/f s2.50.

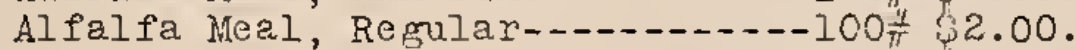

BLATCHFORD'S PROTUCTS

Calf Meal (There is nothing just as good) 507 bars $32.75 ; 25 \#$ bags 1.50; 100 \# bags

Ege Mash (Contains no mill dust) $25 \#$ bagrs $\$ 1.00$ ea; 100 fl bars 3.75 . Chic Mash (Unexcelled for starting, gro:inz, and maturing chics)

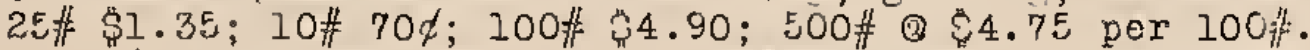

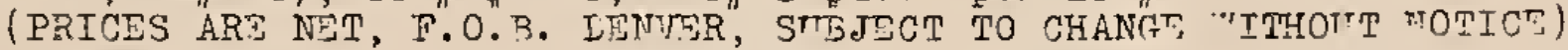

\section{FFRTITIT ARS (Gannot be mailed)}

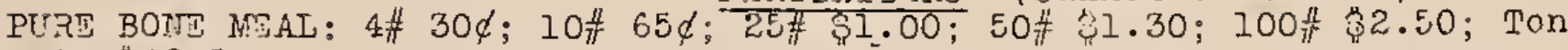
lots $\$ 42.50$.

IAIIT DRESSING: 100\#

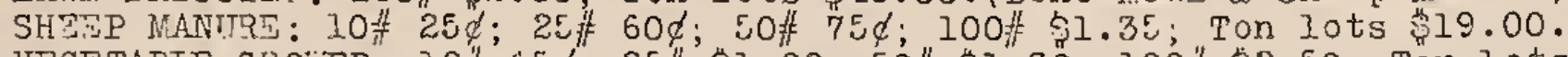

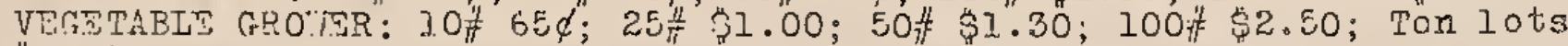
340.00 .

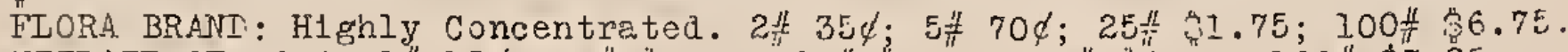

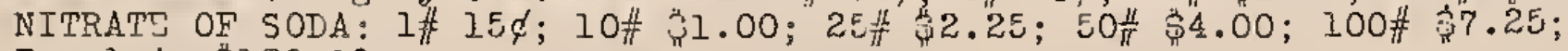
Ton Lots

Alfalfa, Clovers, Peas, Beans and all Le שumes shom better yields when the seed is treated with Nitrapin. See descriptions and prices on different cultures and sizes on pape 87 of our preneral catalof. Additional literature sent on reoust.

Txplanations of their different uses ifiL on found on pages 86 and 87 in our catalog and we can a].so rail charts and other literature on request.

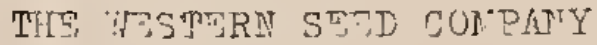

1421-15th street,

DTIVERR, COLORALO. 



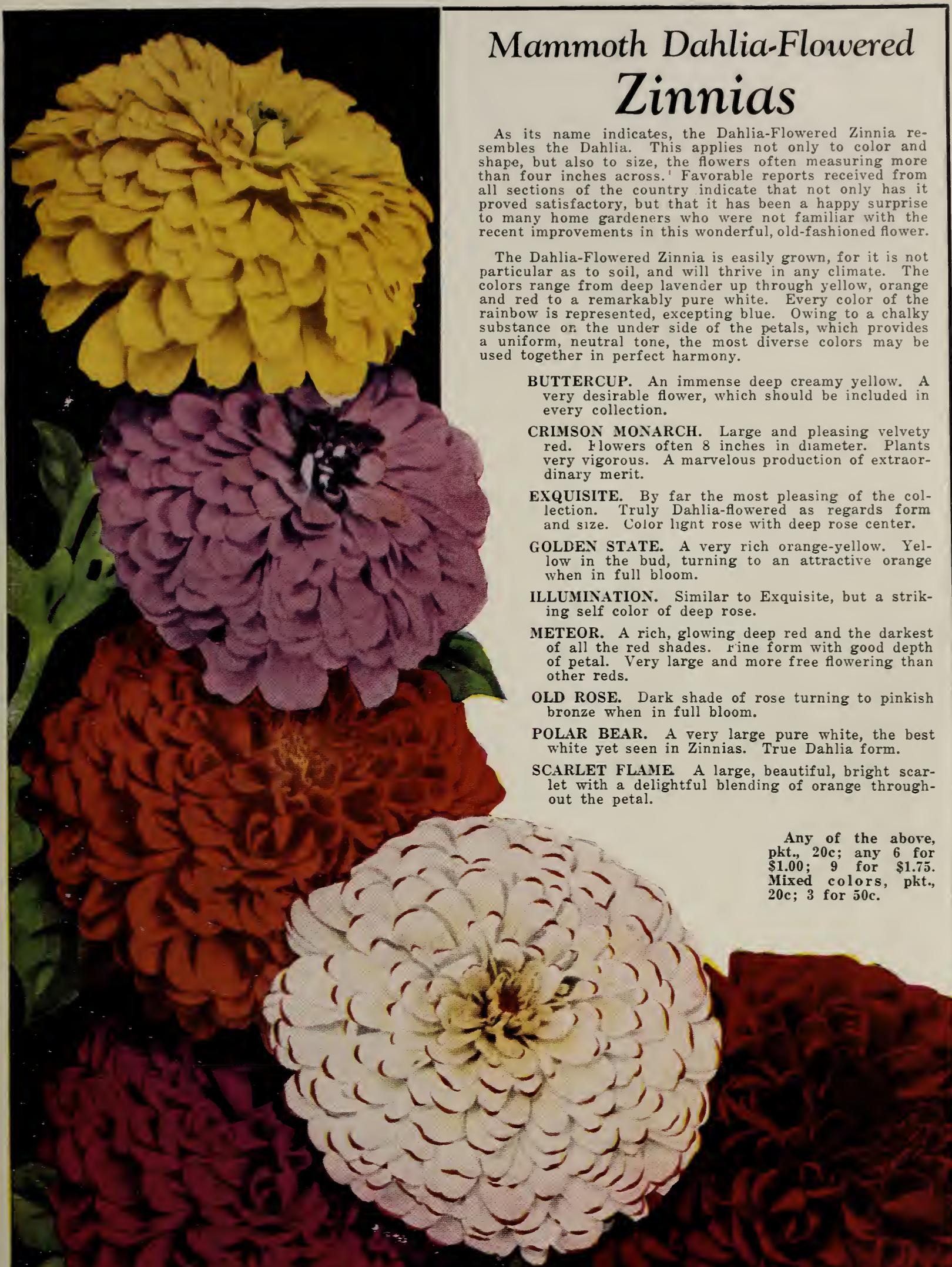




\section{The Three Mountain Varieties Market Garden Winners}

Improved New York or Wonderful Lettuce

Our seed of this variety of Lettuce is of the highest quality and germination, especially selected and bred for the Rocky Mountain regions. For complete description, see page 21 .

Pa sket, 10c; oz., 25c; 1/4 lb., 90c; $1 / 2$ lb., $\$ 1.50 ; 1$ lb., $\$ 2.75$.

\section{Dwarf Telephone Peas}

Reccmmended for the main crop, especially adapted to mountain planting. We produce this seed from carefully bred and selected healthy fields.

Large packet, $10 \mathrm{c} ; \mathrm{x} / 2 \mathrm{lb}$., 25c; 5 lbs., \$1.75; 10 lbs., \$3.25, postpaid.

For further description and larger amounts, sce page 31 :

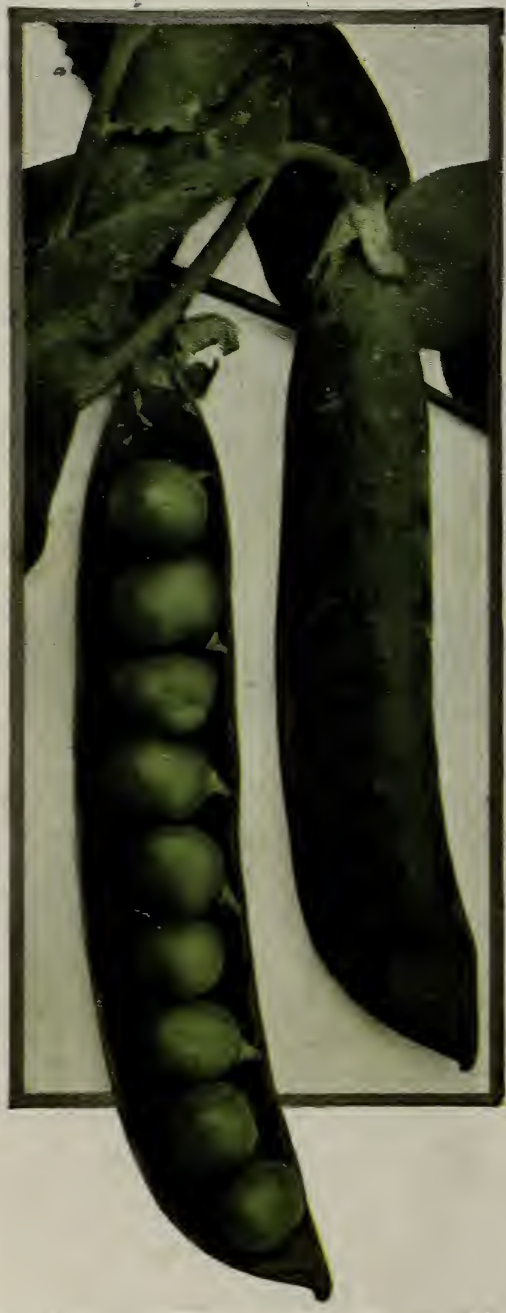

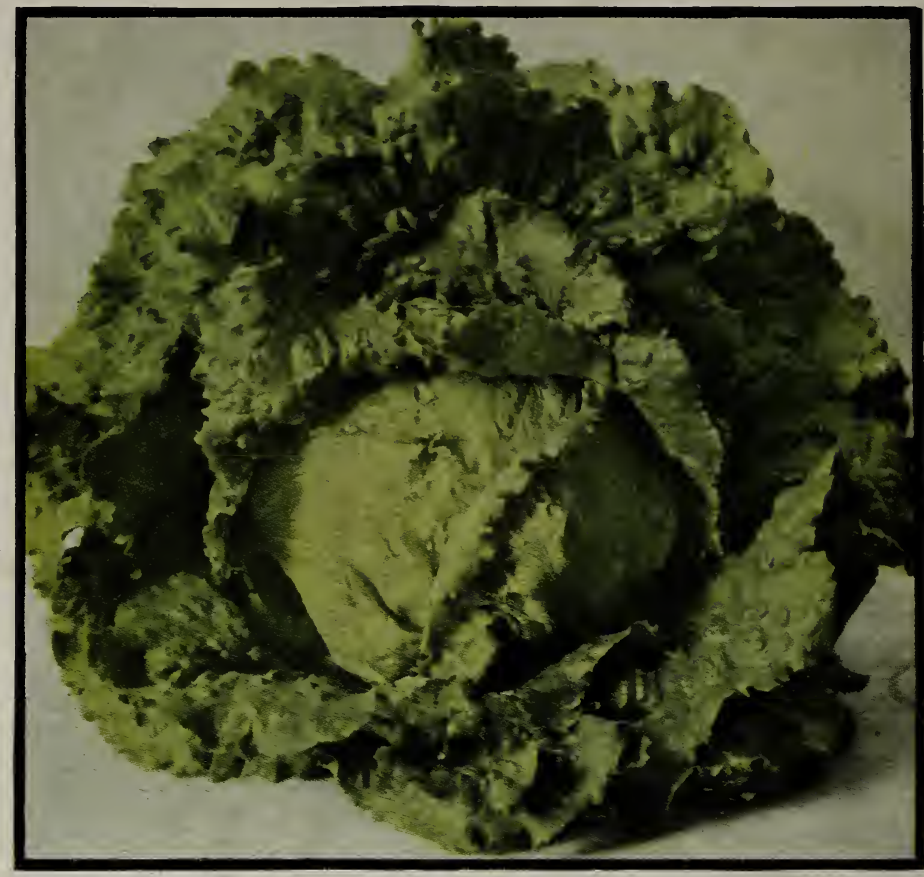

\section{Silver Spray Cauliflower}

New main crop, early. It is just as early as early Snowball, but forms very fine, solid, compact, white heads. Recommended for heavy, rich lands. See page 11 .

Price, packet, 25c; 1/4 oz., 90c; oz., \$2.50; 1/4 lb., \$9.00; 1 lb., $\$ 30.00$, postpaid.

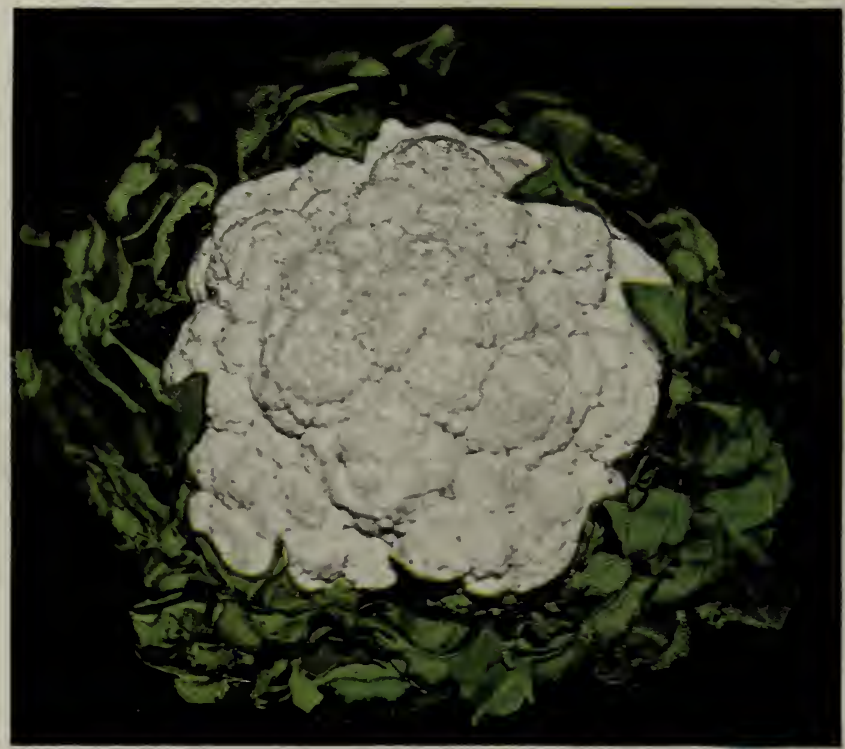

